Ship Forces on the Shoreline of the Savannah Harbor Project

Stephen T. Maynord

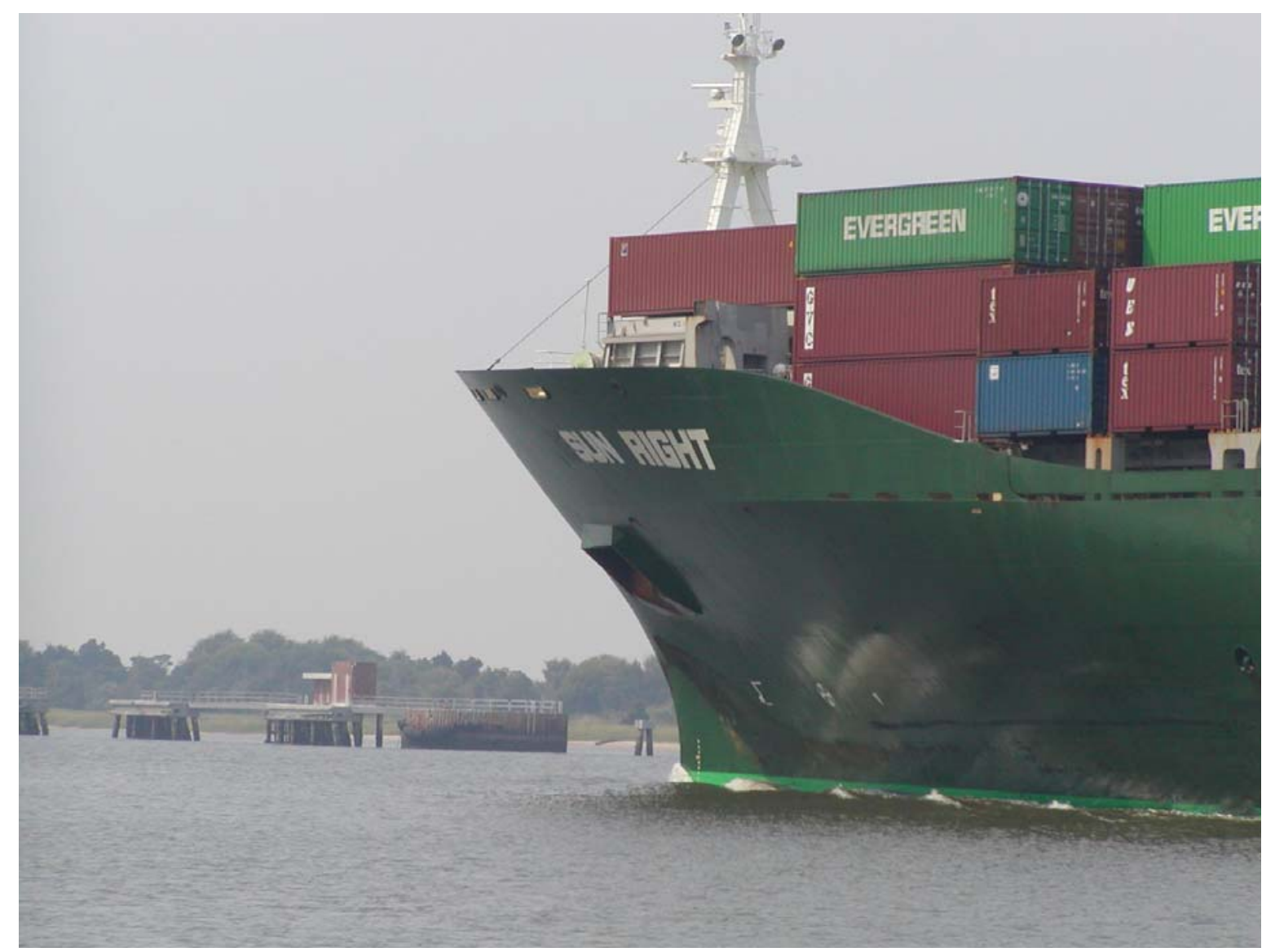




\title{
Ship Forces on the Shoreline of the Savannah Harbor Project
}

\author{
Stephen T. Maynord \\ Coastal and Hydraulics Laboratory \\ U.S. Army Engineer Research and Development Center \\ 3909 Halls Ferry Road \\ Vicksburg, MS 39180-6199
}

Final report

Approved for public release; distribution is unlimited. 


\begin{abstract}
Ship forces having the potential to cause shoreline erosion were evaluated at Savannah Harbor to compare the without-project (existing) and the with-project (deepened) channels. Comparable ship speeds were determined in the without-project and with-project channels based on field data and an analytical model. Four traffic alternatives were evaluated that primarily differ in the number of post-Panamax ships compared to Panamax ships. At Fort Pulaski, dominant ship effects include short period bow and stern waves and long period drawdown and return velocity. The composite return velocity and drawdown per ship are 3.2 to 6.2 percent less in the with-project channel. Due to the slightly higher speed in the with-project channel, short period bow and stern waves are the shoreline attack force that increases in the with-project channel at Fort Pulaski. The composite short period bow and stern wave height per ship for years 2030 and 2050 is predicted to be 1.5 to 4.4 percent greater in the deepened channel. At Tybee Island, the only significant ship effect reaching the shoreline is the long period drawdown or pressure wave. The composite drawdown in the channel between the jetties per ship is 2.3 to 5.9 percent less in the with-project channel.
\end{abstract}

DISCLAIMER: The contents of this report are not to be used for advertising, publication, or promotional purposes. Citation of trade names does not constitute an official endorsement or approval of the use of such commercial products. All product names and trademarks cited are the property of their respective owners. The findings of this report are not to be construed as an official Department of the Army position unless so designated by other authorized documents. 


\section{Contents}

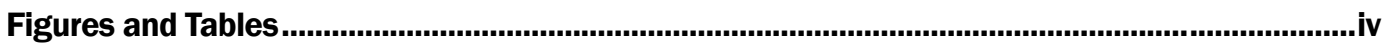

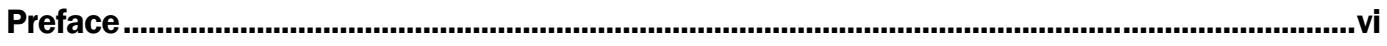

Unit Conversion Factors.................................................................................................................

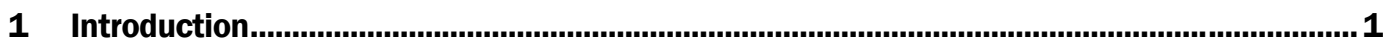

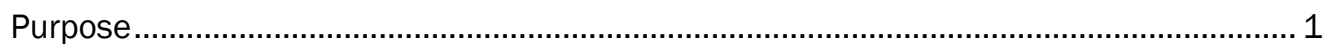

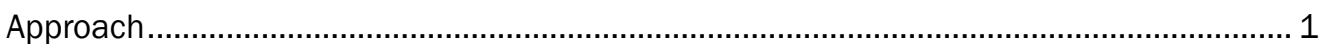

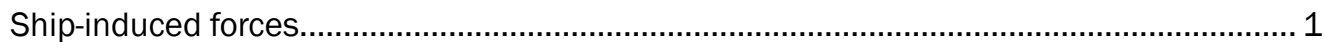

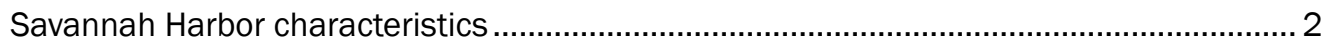

Savannah Harbor ship forces ...................................................................................... 3

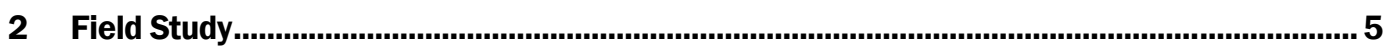

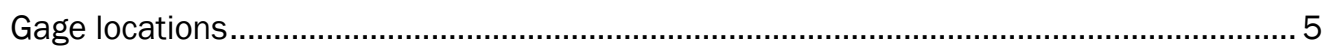

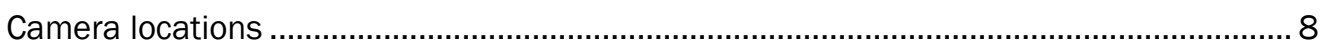

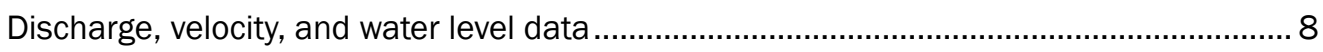

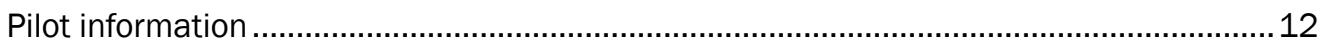

Measured water level data .................................................................................... 12

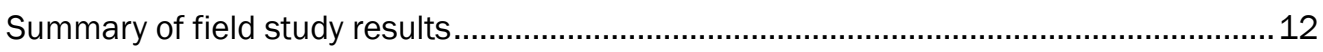

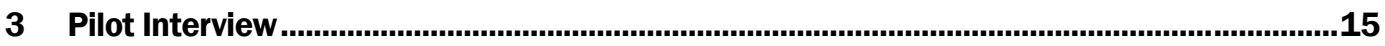

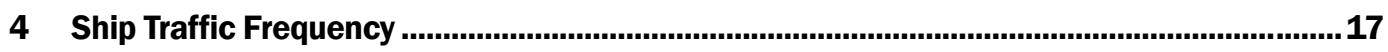

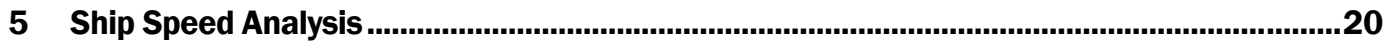

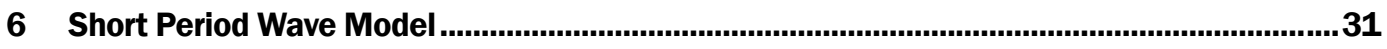

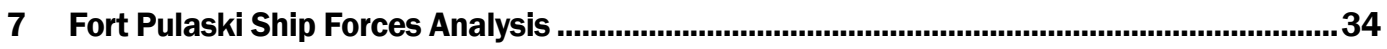

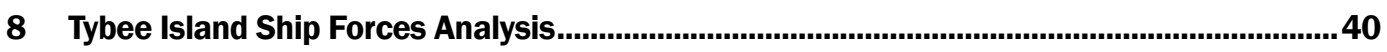

9 Confined Disposal Facility and City Front Ship Effects.......................................................47

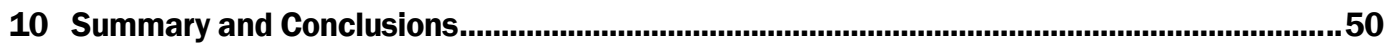

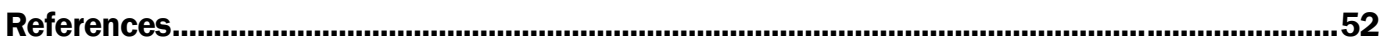

Appendix A: Ship Wave Height at City Front, Pressure Cell 10504 ............................................53

Appendix B: Ship Wave Height at Confined Disposal Facility, Wave Gauge CH3 .........................73

Appendix C: Ship Wave Height at Fort Pulaski, Wave Gauge CH2

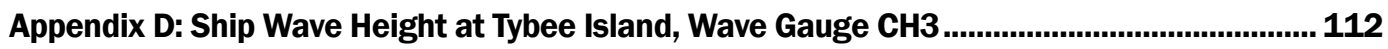

Report Documentation Page 


\section{Figures and Tables}

\section{Figures}

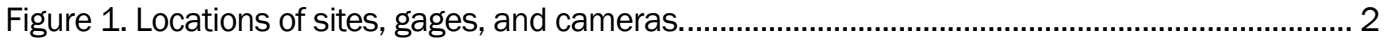

Figure 2. Picture of capacitance gage at Tybee Island. .................................................................... 6

Figure 3. Picture of capacitance gage at Fort Pulaski........................................................................ 7

Figure 4. Cross section at Tybee Island - south jetty to wave gage. ................................................. 9

Figure 5. Cross section at Tybee Island - between jetties. .............................................................. 9

Figure 6. Cross section at Fort Pulaski......................................................................................... 10

Figure 7. Cross section at CDF............................................................................................. 10

Figure 8. Cross section at City Front ....................................................................................... 11

Figure 9. Tides at Fort Pulaski during field study. …………..................................................... 11

Figure 10. Ship speed along reach for inbound ships................................................................ 24

Figure 11. Ship speed along reach for outbound ships. .............................................................. 24

Figure 12. Ship speed versus ship size at City Front. ................................................................. 26

Figure 13. Ship speed versus ship size averaged over CF to CDF reach.........................................26

Figure 14. Ship speed versus ship size at CDF camera. ............................................................ 27

Figure 15. Ship speed versus ship size averaged over CDF to Fort Pulaski reach........................... 27

Figure 16. Ship speed versus ship size at Fort Pulaski camera...................................................2 28

Figure 17. Ship speed versus ship size averaged over reach between Fort Pulaski and TI..............28

Figure 18. Ship speed versus ship size at Tybee Island. ................................................................ 29

Figure 19. Observed versus computed short period bow and stern wave height using modified Gates and Herbich equation.

\section{Tables}

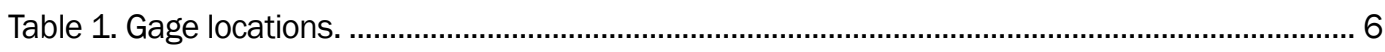

Table 2. Discharge and velocity from ADCP measurements............................................................. 8

Table 3. Ship log with ship characteristics and passage time at gages for inbound ships...............13

Table 4. Classes of container ship traffic for Savannah Harbor. ..................................................... 17

Table 5. Field study ships categorized according to vessel type used in Savannah District

fleet forecast. Category based on ship beam................................................................................. 17

Table 6. Container ship traffic for Savannah Harbor. Numbers are for both without- and

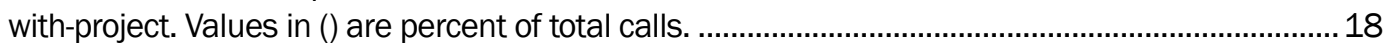

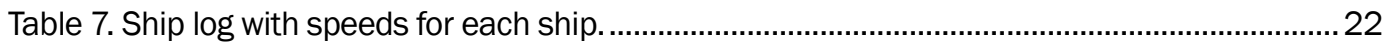

Table 8. Summary of ship speeds along channel from field study.................................................2

Table 9. Ship effects analysis for Fort Pulaski. Return velocity and drawdown are averages over cross section based on Schijf equation in NAVEFF.

Table 10. Composite return velocity $\left(\mathrm{V}_{r}\right)$, drawdown, and short period bow and stern wave height for Fort Pulaski based on Table 9 and ship frequency in Table 6 for GEC scenario. Values in () show percent change from without-project to with-project. 
Table 11. Composite return velocity, drawdown, and short period bow and stern wave height for Fort Pulaski based on Table 9 and ship frequency in Table 6 for 10 percent scenario. Values in () show percent change from without-project to with-project.

Table 12. Composite return velocity, drawdown, and short period bow and stern wave height for Fort Pulaski based on Table 9 and ship frequency in Table 6 for 20 percent scenario. Values in () show percent change from without-project to with-project.

Table 13. Composite return velocity, drawdown, and short period bow and stern wave height for Fort Pulaski based on Table 9 and ship frequency in Table 6 for 30 percent scenario. Values in () show percent change from without-project to with-project.

Table 14. Tybee Island ship drawdown.

Table 15. Design ship analysis for Tybee Island. Return velocity and drawdown are averages over cross section based on Schijf equation.

Table 16. Composite drawdown for Tybee Island based on Table 15 and ship frequency in Table 6 for GEC traffic scenario. Values in () show percent change from without-project to with-project

Table 17. Composite drawdown for Tybee Island based on Table 15 and ship frequency in Table 6 for 10 percent traffic scenario. Values in () show percent change from withoutproject to with-project.

Table 18. Composite drawdown for Tybee Island based on Table 15 and ship frequency in Table 6 for 20 percent traffic scenario. Values in () show percent change from withoutproject to with-project

Table 19. Composite drawdown for Tybee Island based on Table 15 and ship frequency in Table 6 for 30 percent traffic scenario. Values in () show percent change from withoutproject to with-project.

Table 20. Drawdown in existing channel for CDF ships.

Table 21. Drawdown in existing channel for CF ships. 


\section{Preface}

The work reported herein was conducted for the U.S. Army Engineer District, Savannah by the U.S. Army Engineer Research and Development Center (ERDC) during 2005-2006. The field work was performed during September 2005 by personnel of ERDC and the Savannah District. From ERDC, Thad Pratt, J ohn Kirklin, Chris Callegan, and Dr. Stephen Maynord participated in the field studies. From the Savannah District, Wilbur Wiggins participated in the data collection.

The study was conducted under the direction of Thomas W. Richardson, Director, Coastal and Hydraulics Laboratory (CHL); Dr. William D. Martin, Deputy Director, CHL; Dr. Rose Kress, Chief of the Navigation Division, CHL; and Dennis Webb, Chief of the Navigation Branch, CHL. The report was written by Dr. Maynord.

COL Richard B. J enkins was Commander and Executive Director of ERDC. Dr. J ames R. Houston was Director. 


\section{Unit Conversion Factors}

\begin{tabular}{|l|c|l|}
\hline Multiply & By & To Obtain \\
\hline cubic feet & 0.02831685 & cubic meters \\
\hline degrees (angle) & 0.01745329 & radians \\
\hline degrees Fahrenheit & (F-32)/1.8 & degrees Celsius \\
\hline feet & 0.3048 & meters \\
\hline foot-pounds force & 1.355818 & joules \\
\hline horsepower (550 foot-pounds force per second) & 745.6999 & watts \\
\hline knots & 0.5144444 & meters per second \\
\hline miles (U.S. statute) & $1,609.347$ & meters \\
\hline miles per hour & 0.44704 & meters per second \\
\hline pounds (force) & 4.448222 & newtons \\
\hline pounds (force) per square foot & 47.88026 & pascals \\
\hline slugs & 14.59390 & kilograms \\
\hline square feet & 0.09290304 & square meters \\
\hline
\end{tabular}




\section{Introduction}

\section{Purpose}

At the request of the U.S. Army Engineer District, Savannah, the U.S. Army Engineer Research and Development Center (ERDC) conducted an evaluation of ship forces that may cause shoreline erosion in the withoutproject (existing) channel and in the with-project (deepened) channel of the Savannah Harbor project. ERDC was asked to determine ship induced waves, drawdown, and velocity increase at the shoreline. In a follow-up study, the District will use results of this study to determine any changes in shoreline erosion in the existing and deepened channels.

\section{Approach}

The study was accomplished using (a) field measurement of ship forces and (b) analytical/ empirical models to compare ship forces in the withoutproject (existing) and with-project (deepened) channels. The District asked ERDC to provide a comparison of ship forces in the existing and the deepened channels for the Fort Pulaski (FP) and Tybee Island (TI) sites (Figure 1). For the City Front and the Confined Disposal Facility sites, the District asked ERDC to provide a table showing ship forces in the existing channel. The term "channel" in this report refers to the entire width of the waterway, not just the navigable portion of the waterway.

\section{Ship-induced forces}

The shorelines of the Savannah Harbor Channel are subjected to a variety of ship-induced forces. These forces result from waves generated at the bow and stern of the ship, water level lowering or drawdown from the displacement of the ship, and increased velocity from both waves and return velocity. Return velocity, like drawdown, results from the moving ship displacing water as it travels ahead. The water accelerates around the ship, moving from bow to stern. The increased water velocity alongside the ship is the return velocity. The movement of water from bow to stern also results in lowering of the water level adjacent to the ship; that is called the drawdown. The drawdown, that some refer to as a pressure wave, can travel large distances from the ship, as will be seen in the Tybee Island data. Return velocity is parallel to and opposite to the direction of ship travel. 


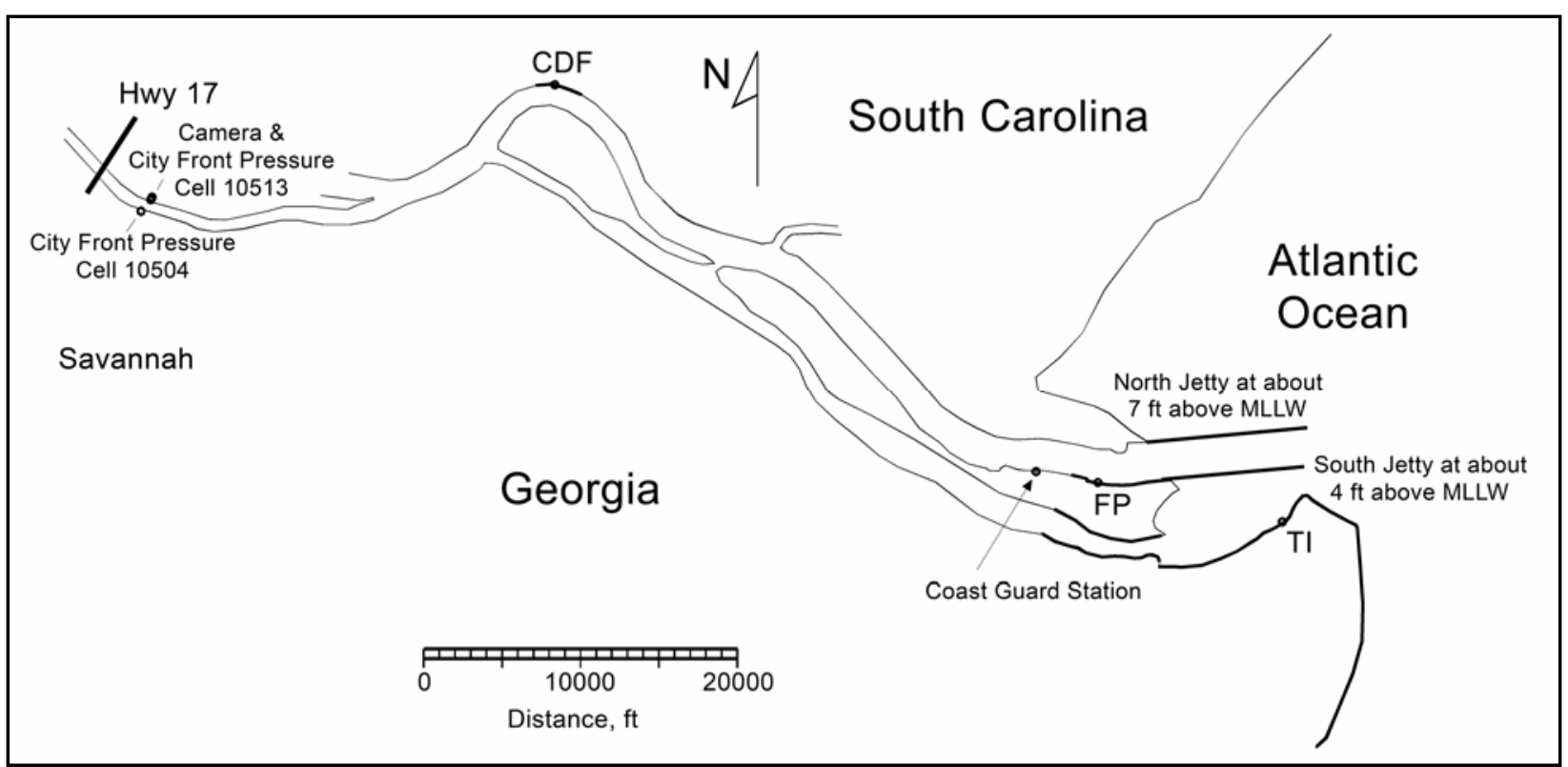

Figure 1. Locations of sites, gages, and cameras.

\section{Savannah Harbor characteristics}

The Savannah Harbor Channel is on the lower limit of what is termed a confined channel. Confined channels are those in which the ship crosssectional area takes up a significant part of the channel cross-sectional area. Confined channels are often described by the blockage ratio; that is, the ratio of ship cross-sectional area/ channel cross-sectional area. Blockage ratio should not be confused with block coefficient, used subsequently that describes the hull shape of a ship. Depending on ship speed, ships having blockage ratios of more than 0.02-0.05 exhibit significant displacement effects that include drawdown and return velocity. Many confined channels have maximum blockage ratios of 0.15-0.2. The Savannah Harbor Channel has blockage ratio from about 0.02-0.095 that places it on the lower end of confined channels. Consequently, drawdown and return velocity impacts should be less than in channels with higher blockage ratios.

Confined channels can have ship passages that create a large rise in water level just after the drawdown. The water level rise is most often a single wave that inundates shoreline areas above the ambient water level. The drawdown plus the water level rise is frequently referred to as a transverse stern wave. The magnitude of the rise in water level above the ambient water level is a function of ship speed, shoreline geometry, channel size, 
and proximity of the ship to the shoreline. The Savannah District provided a video that showed such an occurrence on the Savannah Harbor project.

During the field study, numerous ships produced a water level rise of about $1 \mathrm{ft}$. Only the Mol Velocity, that was an inbound ship at the Confined Disposal Facility, created a water level rise or transverse stern wave comparable to that seen on the video. As shown in Appendix B, Figure B-5, the Mol Velocity created a 2.5-ft drawdown followed by a 3-4-ft rise in water level above the ambient water level. While transverse stern waves are often the dominant force on the shoreline in confined channels, the frequency of occurrence on the Savannah Harbor Channel appears low based on the field data.

Another characteristic of the Savannah Harbor Channel is that the traffic is predominantly container ships, which have relatively high ship speeds compared to other types of ships such as tankers and bulk carriers. The relatively low blockage ratio in the Savannah Harbor also results in higher ship speeds. In deep-draft navigation channels dominated by tankers or bulk carriers, ship speed is relatively slow and the ships' forces at the shoreline of main concern are the long period effects related to the ship induced drawdown such as the transverse stern wave. The higher speed of the container ships and the low blockage ratio at Savannah Harbor raise the possibility that short period bow and stern waves are the dominant force on the shoreline.

A third characteristic of the Savannah Harbor Channel is the presence of large tides and large tidal velocities. The large tidal range tends to spread the attack of ship effects over a significant portion of the shoreline rather than occurring at the same location on the shoreline, as would be the case in the absence of tides. A negative aspect of large tidal velocities is that return velocity adds to the ambient velocity for ships going against the tide, resulting in net velocities well above ambient velocities.

\section{Savannah Harbor ship forces}

Summarizing, the ship forces having potential to impact shoreline erosion at Savannah Harbor are as follows:

1. Short period waves formed at bow and stern of ship.

2. Long period drawdown and return velocity caused by the displacement of water by the moving ship. Based on the low frequency of occurrence in the 
field data, transverse stern waves, which are also caused by the displacement effects of the ship, will not be considered in the analysis.

One of the most critical questions in ship effects studies of existing and deepened channels is as follows: "What is the speed of comparable ships in the without-project (existing) and the with-project (deepened) channels?" The study outcome strongly depends on the answer to this question. 


\section{Field Study}

\section{Gage locations}

The field study was conducted from 15 September - 22 September 2005. Water level measurements were conducted at both sides of the channel at City Front (CF), the north side of the channel at the Confined Disposal Facility (CDF), the south side of the channel at Fort Pulaski (FP), and the shoreline at Tybee Island (TI) south of the jetties as shown in Figure 1. The District had concerns about ship effects at high tides, and the field study was timed to coincide with a spring tide. By selecting the spring tide full moon, the maximum moonlight conditions were present to improve the performance of the cameras used for nighttime data collection.

The locations of the single pressure cell used at each of the two CF sites and the two 13-ft-long capacitance rods used at each of the CDF, FP, and TI sites are shown in Table 1 . The wave stands containing the two capacitance rods, video camera, and recorder at TI and FP are shown in Figures 2 and 3. Two gages were provided for redundancy; there was no attempt to extract wave direction from the data. Because the District was concerned about ship effects at high tides reaching $9 \mathrm{ft}$ MLLW, the 13-ftlong capacitance rods were positioned to measure water levels up to about 11.5 to $12.0 \mathrm{ft} \mathrm{MLLW}$. This placed the lower limit of the capacitance rods at about - 1 to $-1.5 \mathrm{ft}$ MLLW. The lateral position of the gages was selected where the channel bottom elevation was about - $2 \mathrm{ft}$ MLLW. As can be seen in the measured data in the appendices, ship passages at extreme low tides often caused a water level drawdown lower than the bottom of the capacitance gages. When this happened, the data was a flat line until the water level rose back onto the gage. See, for example, Figures B-10, C-4, and C-31 in the appendices. Unwatering of the gage only occurred at FP and CDF. Unwatering did not happen at CF because the pressure cells were adequately submerged. Unwatering of the capacitance gages did not happen at TI because of the reduced magnitude of drawdown. 
Table 1. Gage locations.

\begin{tabular}{|c|c|c|c|c|c|}
\hline Location & $\begin{array}{l}\text { Side of } \\
\text { Channel }\end{array}$ & $\begin{array}{l}\text { Depth, date, } \\
\text { time at } \\
\text { instrument }\end{array}$ & $\begin{array}{l}\text { Starting, end } \\
\text { date/time of } \\
\text { Gage }\end{array}$ & $\begin{array}{l}\text { Starting, end } \\
\text { date/time of } \\
\text { Camera }\end{array}$ & $\begin{array}{l}\text { State Plane, ft Georgia } \\
\text { East } 1001\end{array}$ \\
\hline City Front & South & $\begin{array}{l}10-12 \mathrm{ft} 9 / 17 \\
\text { at } 1323 \mathrm{EST}\end{array}$ & $\begin{array}{l}\text { 9/17 at } 1323 \\
\text { EST, } 9 / 21 \text { at } \\
\text { 0600 EST }\end{array}$ & $\begin{array}{l}\text { No camera on } \\
\text { South }\end{array}$ & 989350,758867 \\
\hline City Front & North & $\begin{array}{l}10-12 \mathrm{ft} 9 / 17 \\
\text { at } 1313 \mathrm{EST}\end{array}$ & $\begin{array}{l}\text { 9/17 at } 1313 \\
\text { EST, } 9 / 21 \text { at } \\
0600 \text { EST }\end{array}$ & $\begin{array}{l}\text { 9/17 at } 1430 \\
\text { EST, } 9 / 21 \text { at } \\
0756 \text { EST }\end{array}$ & $\begin{array}{l}989966,759588 \text { Camera } \\
\text { at } 990049,759744\end{array}$ \\
\hline $\begin{array}{l}\text { Confined } \\
\text { Disposal } \\
\text { Facility }\end{array}$ & North & $\begin{array}{l}2.4 \mathrm{ft} 9 / 19 \text { at } \\
1450 \mathrm{EST}\end{array}$ & $\begin{array}{l}\text { 9/18 at } 1200 \\
\text { EST, } 9 / 21 \text { at } \\
\text { 0600 EST }\end{array}$ & $\begin{array}{l}9 / 15 \text { at } 1620 \\
\text { EST, } 9 / 21 \text { at } \\
\text { 0600 EST }\end{array}$ & 1015691,766862 \\
\hline Fort Pulaski & South & $\begin{array}{l}2.3 \mathrm{ft} 9 / 19 \text { at } \\
1416 \mathrm{EST}\end{array}$ & $\begin{array}{l}9 / 16 \text { at } 1400 \\
\text { EST, } 9 / 20 \text { at } \\
1400 \text { EST }\end{array}$ & $\begin{array}{l}9 / 18 \text { at } 1445 \\
\text { EST, } 9 / 20 \text { at } \\
1400 \text { EST }\end{array}$ & 1050315,741509 \\
\hline Tybee Island & South* & $\begin{array}{l}3.6 \mathrm{ft} 9 / 19 \text { at } \\
1328 \mathrm{EST}\end{array}$ & $\begin{array}{l}9 / 16 \text { at } 1200 \\
\text { EST, } 9 / 20 \text { at } \\
1200 \text { EST }\end{array}$ & $\begin{array}{l}9 / 16 \text { at } 1215 \\
\text { EST, } 9 / 20 \text { at } \\
1200 \text { EST }\end{array}$ & $\begin{array}{l}1062178,739026 \text { center } \\
\text { of view in camera in } \\
\text { channel = } 1060478, \\
743335\end{array}$ \\
\hline
\end{tabular}

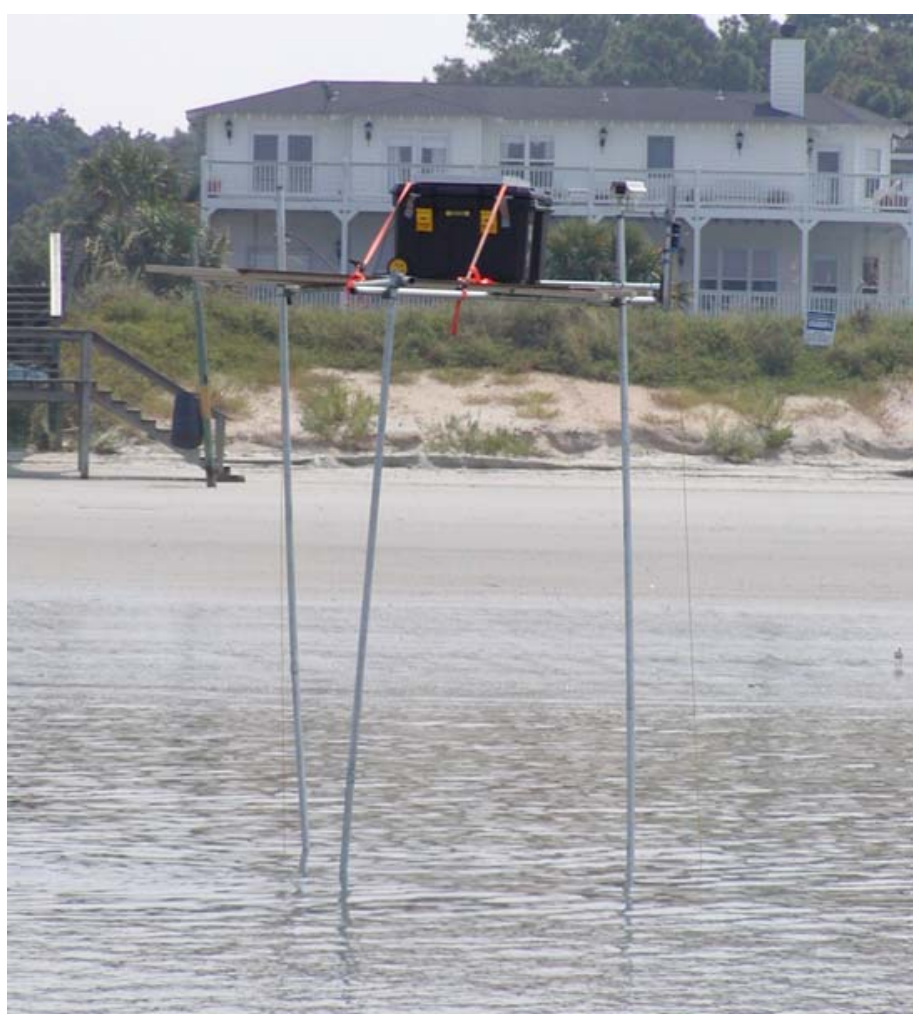

Figure 2. Picture of capacitance gage at Tybee Island. 


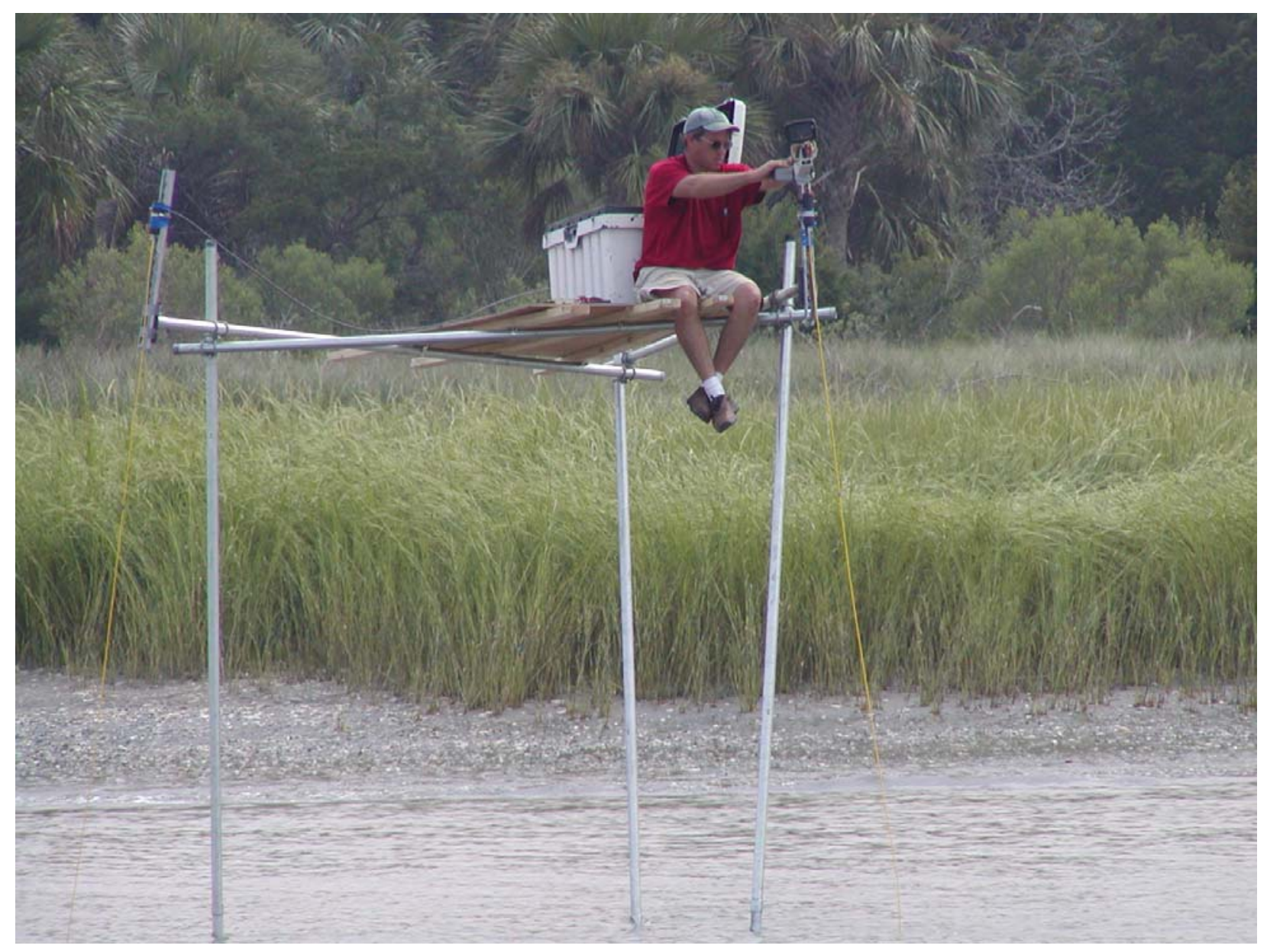

Figure 3. Picture of capacitance gage at Fort Pulaski.

The large tidal range in the Savannah Harbor Channel makes the measurement of ship induced water level changes difficult. In addition to the problems with measurement of the entire tidal range mentioned previously, the ship effects at low tides are measured with the gages close to the shoreline in shallow water versus the ship effects at high tides that are measured with gages in deeper water farther from the shoreline. Shallow water and shoreline proximity affect both the long period effects and short period bow and stern waves from the ship. Decreasing depth has several effects on waves, the most significant of which is shoaling, which is the increase in wave height as waves move into shallow water. The increase in height occurs until the wave steepness reaches the point at which the wave breaks. These observations on shallow-water effects explain some of the variability in the data but do not reduce the validity of the results. 


\section{Camera locations}

Cameras were mounted on the wave stands at CDF, FP, and TI to monitor passage of ship traffic. A camera at $\mathrm{CF}$ was mounted on the north side of the channel at the coordinates shown in Table 1. Cameras having low light capability were used in an attempt to observe ship characteristics during the night.

\section{Discharge, velocity, and water level data}

Discharge and velocity data from Acoustic Doppler Current Profiler (ADCP) measurements taken on September 19 at the four gage locations are shown in Table 2. Cross sections from the ADCP measurements at the four locations are shown in Figures 4-8. The observed preliminary water levels from the National Oceanic and Atmospheric Administration (NOAA) tide gage at FP are shown in Figure 9. Water levels and channel bathymetry are presented in MLLW. Winds during the field study were generally low, which was important at the TI gage to prevent problems with separating wind waves from ship waves. Until about midday on September 19, 2005, winds were from the south at about 4 knots. After midday on the 19th, winds were from the east-northeast at about 10 knots. The TI gage was protected somewhat from wind waves from the eastnortheast by Tybee Island Point as shown in Figure 1.

Table 2. Discharge and velocity from ADCP measurements.

\begin{tabular}{|c|c|c|c|c|c|c|c|}
\hline Location & $\begin{array}{l}\text { avg time } \\
\text { EST }\end{array}$ & $\begin{array}{l}\text { Tide Level at Ft Pulaski T } \\
\text { [ft] }\end{array}$ & $\begin{array}{l}\text { Total Q } \\
{\left[\mathrm{ft}^{3} / \mathrm{s}\right]}\end{array}$ & $\begin{array}{l}\text { Total A } \\
{\left[\mathrm{ft}^{2}\right]}\end{array}$ & $\begin{array}{l}\text { Width } \\
{[\mathrm{ft}]}\end{array}$ & $\begin{array}{l}\text { Q/Area } \\
{[\mathrm{ft} / \mathrm{s}]}\end{array}$ & $\begin{array}{l}\text { Tide } \\
\text { Direction }\end{array}$ \\
\hline Tybee, inside jetties & $7: 37: 00$ & 8.20 & 158947 & 74074 & 1852 & 2.1 & Flood \\
\hline Tybee, inside jetties & $7: 45: 00$ & 8.35 & 154275 & 86204 & 2227 & 1.8 & Flood \\
\hline Fort Pulaski & $7: 58: 00$ & 8.46 & -179768 & 77943 & 2045 & 2.3 & Flood \\
\hline CDF & $8: 20: 00$ & 8.60 & -115335 & 64451 & 1842 & 1.8 & Flood \\
\hline CDF & $8: 27: 00$ & 8.64 & -113793 & 64344 & 1710 & 1.8 & Flood \\
\hline Tybee, gage to jetty & $13: 35: 00$ & 1.50 & 61689 & 30923 & 3452 & 2.0 & Ebb \\
\hline Tybee, inside jetties & $13: 54: 00$ & 1.00 & -214458 & 65271 & 2239 & 3.3 & Ebb \\
\hline Fort Pulaski & $14: 07: 00$ & 0.70 & 210841 & 67189 & 2129 & 3.1 & Ebb \\
\hline CDF & $14: 40: 00$ & 0.10 & 138200 & 50467 & 1443 & 2.7 & Ebb \\
\hline City Front & $15: 10: 00$ & -0.20 & -73799 & 36504 & 944 & 2.0 & Ebb \\
\hline
\end{tabular}




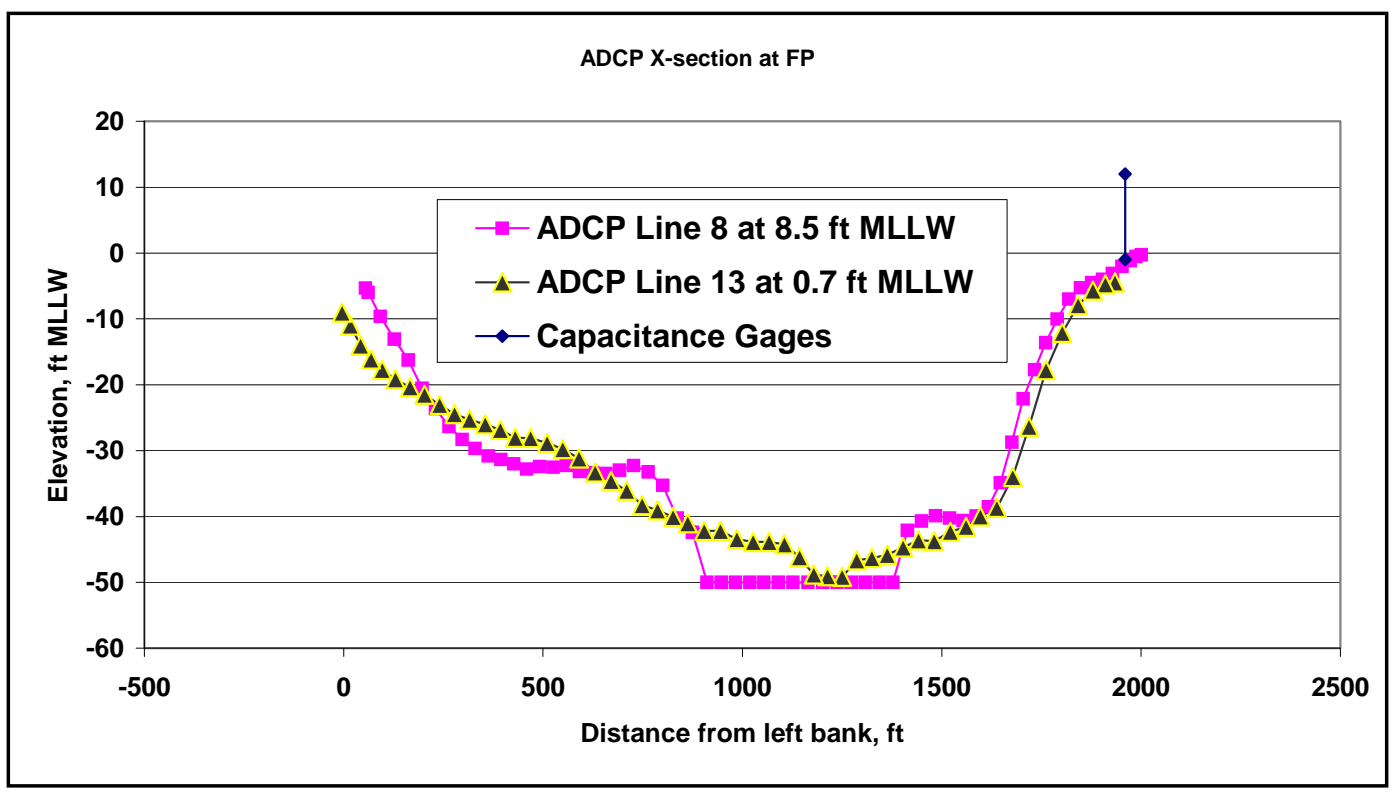

Figure 4. Cross section at Tybee Island - south jetty to wave gage.

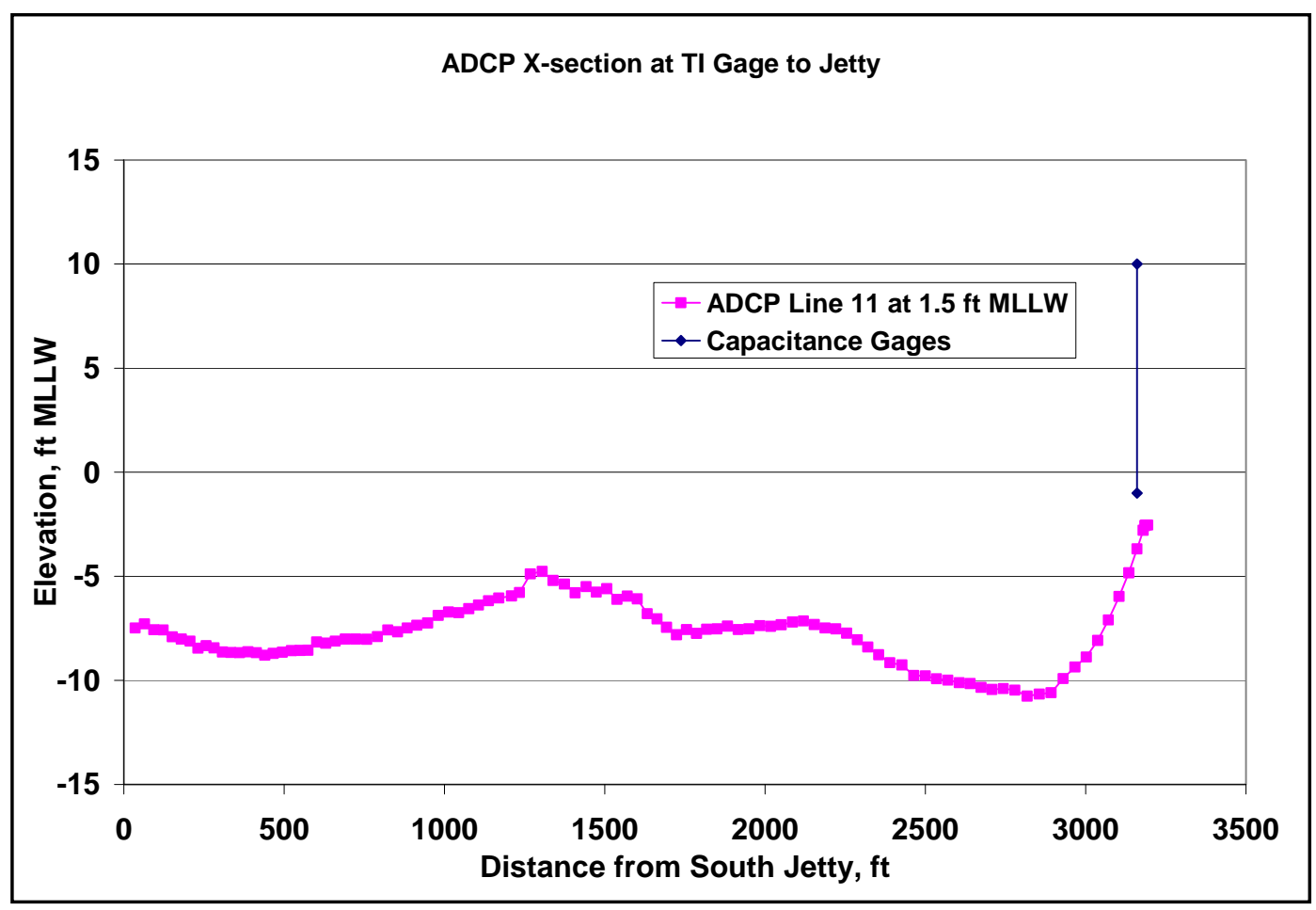

Figure 5. Cross section at Tybee Island - between jetties. 


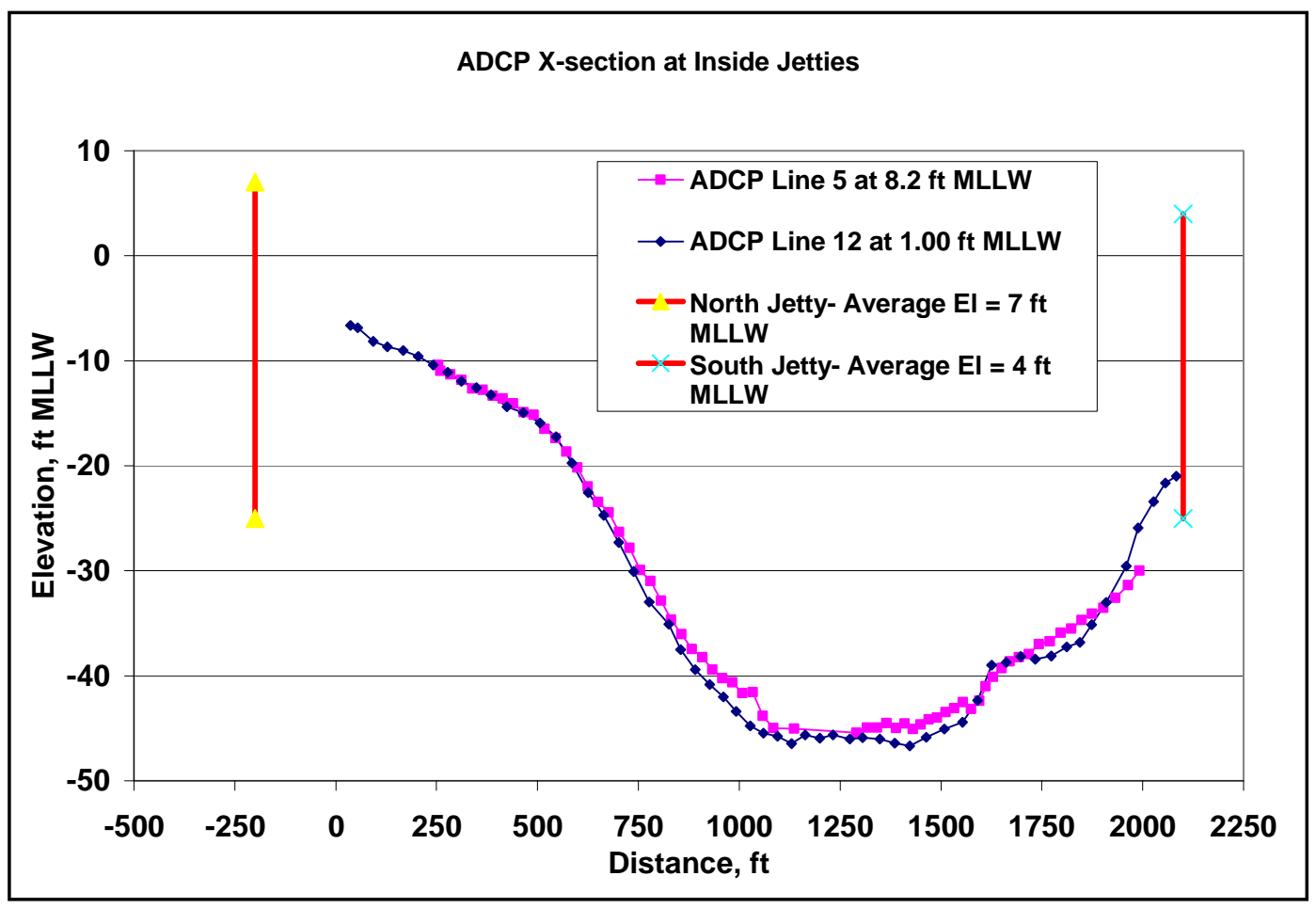

Figure 6. Cross section at Fort Pulaski.

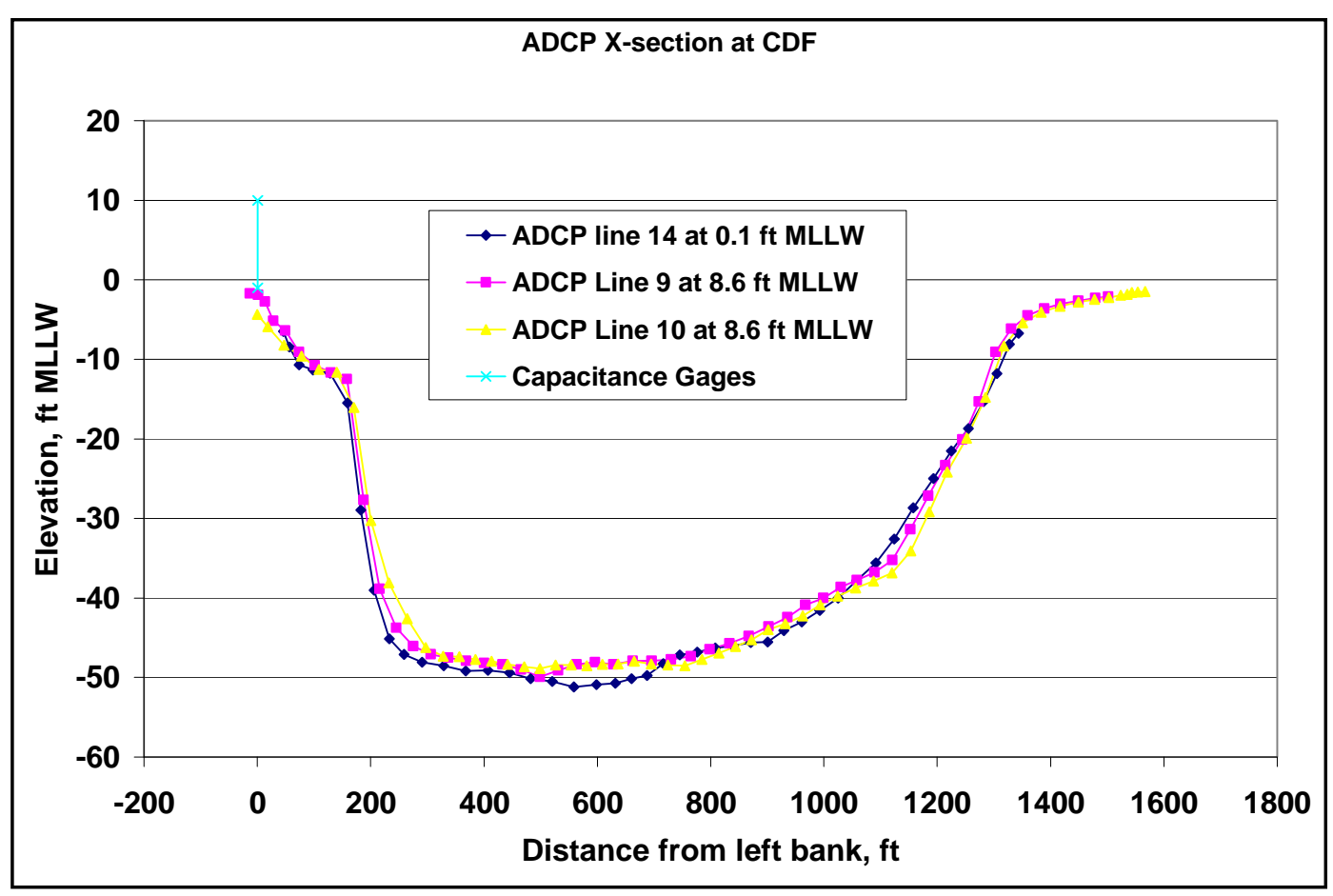

Figure 7. Cross section at CDF. 


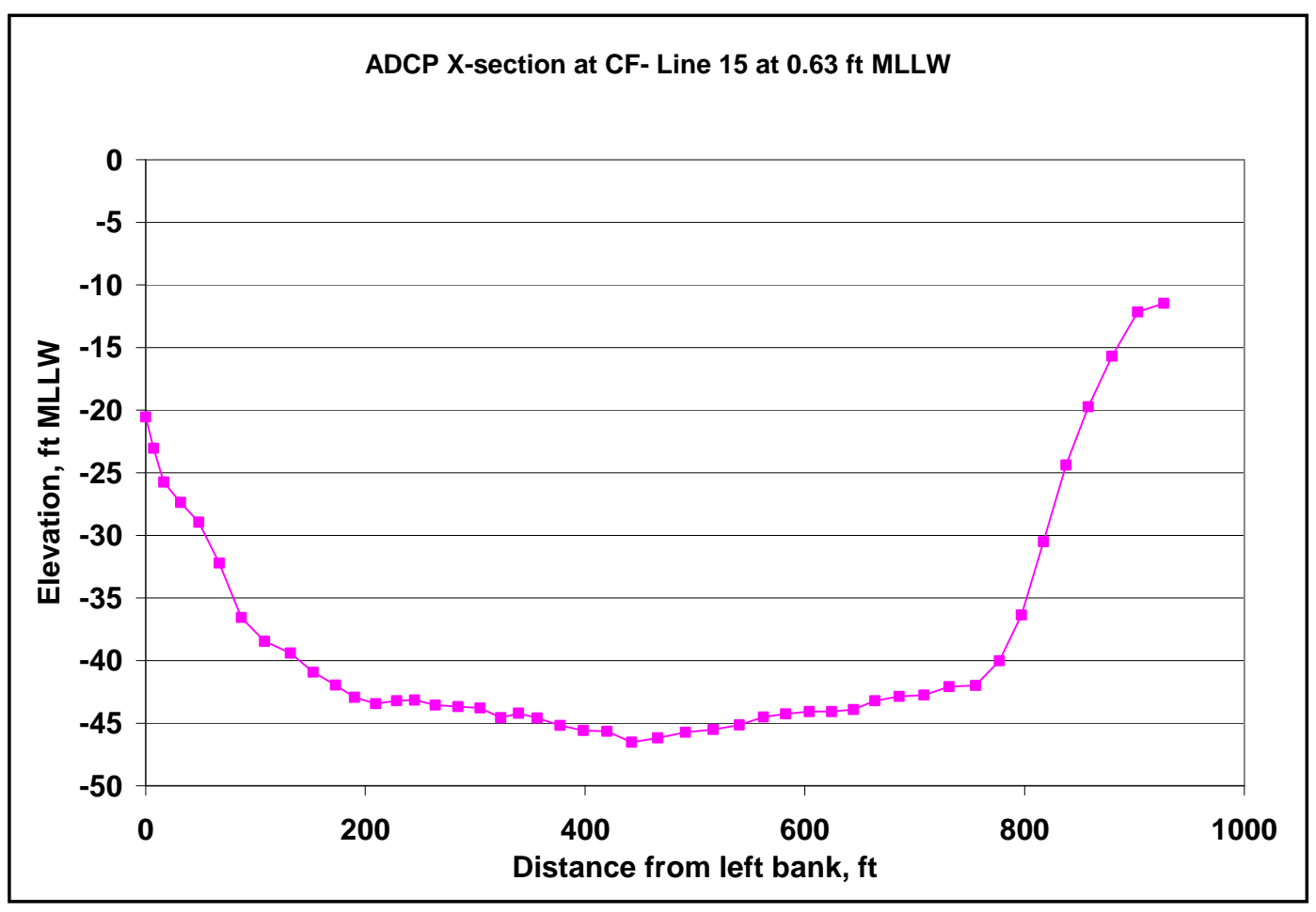

Figure 8. Cross section at City Front

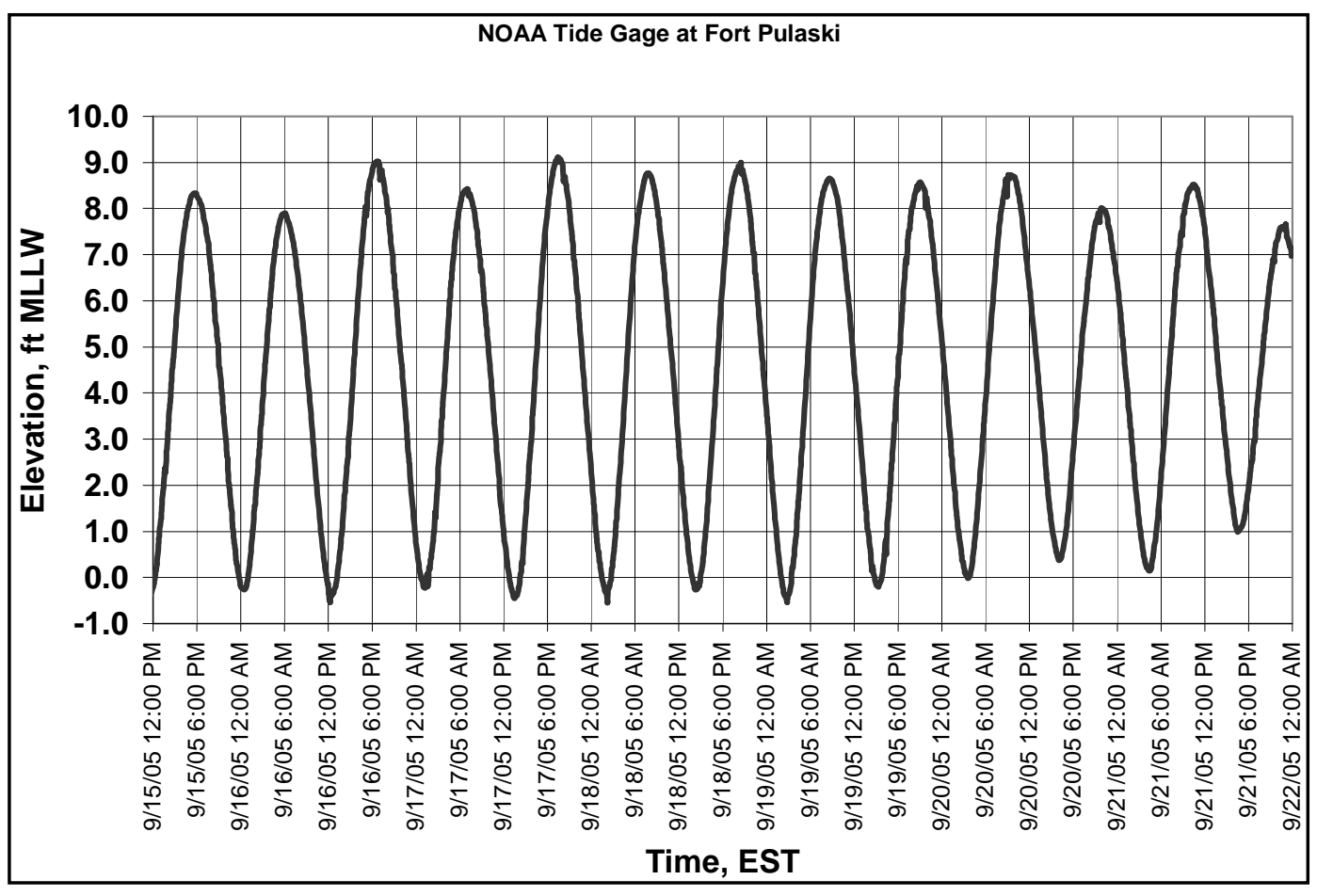

Figure 9. Tides at Fort Pulaski during field study. 


\section{Pilot information}

Along with the camera information, ship transit information was obtained from the Savannah Bar Pilots that included the ship name, the time and date the pilot boarded the ship, direction of travel, dock location, time of docking for inbound transits, and draft (assumed to be average draft because bow and stern draft was not provided). In addition to these parameters, various sources were used to obtain ship type, tonnage, overall length, and beam. This data is shown in Table 3. Each camera and wave gage had known time stamps. Team members recorded daytime ship passage events at the Coast Guard station just west of the FP gage. All of these data were used to determine when specific ships passed each wave gage as shown in Table 3.

\section{Measured water level data}

The time-histories of water level at the four locations along the channel are shown in Appendix A-D. The results for the two capacitance gages were similar so only one was plotted.

\section{Summary of field study results}

The field study provided an understanding of the important shoreline forces in the Savannah Harbor Channel as well as needed data. Results of the field study showed that short period bow and stern waves are important and provided data to select and modify a short period wave equation. The field study also provided speed data that was previously not available and insight into whether the south jetty would block ship effects from reaching TI. 
Table 3. Ship log with ship characteristics and passage time at gages for inbound ships.

\begin{tabular}{|c|c|c|c|c|c|c|c|c|c|c|c|c|c|}
\hline Name & type & $\begin{array}{l}\text { gross } \\
\text { tonnage }\end{array}$ & $\begin{array}{l}\text { length, } \\
\mathrm{ft}\end{array}$ & $\begin{array}{l}\text { beam, } \\
\mathrm{ft}\end{array}$ & draft, $\mathrm{ft}$ & Direct & date & Dock & CF & CDF & FP & $\mathrm{TI}$ & POB time \\
\hline \multicolumn{14}{|l|}{ INBOUND: } \\
\hline flintereems & gen cargo & 4503 & 367 & 49.2 & 20 & in & 15-Sep & 1615 & & 1509 & & & 1320 \\
\hline khannur & $\operatorname{lng}$ & 96235 & 961 & 136.8 & 37.1 & in & 15-Sep & 1645 & & & & & 1330 \\
\hline maersk garonne & cont & 50698 & 958 & 105.9 & 32.66 & in & 15-Sep & 2045 & & 1854 & & & 1720 \\
\hline ym south & cont & 46697 & 906 & 105.6 & 37.9 & in & 15-Sep & 2300 & & 2036 & & & 1810 \\
\hline Jiang An Cheng & & 16703 & 571 & 83.97 & 23.75 & in & 15-Sep & 115 & & 2322 & & & 2130 \\
\hline leyla kalkavan & cont & 9978 & 489 & 74.46 & 22.9 & in & 15-Sep & 200 & & 16 & & & 2245 \\
\hline xin fang cheng & cont & 41482 & 861 & 105.9 & 31.8 & in & 16-Sep & 620 & & 417 & & & 250 \\
\hline new york express & cont & 54437 & 965 & 105.9 & 29.5 & in & 16-Sep & 725 & & 530 & & & 400 \\
\hline kyriakoula & oil tanker & 40680 & 750 & 105 & 28 & in & 16-Sep & & & 1555 & 1520 & 1514 & 1405 \\
\hline sun right & cont & 53359 & 965 & 105 & 37.9 & in & 16-Sep & 1725 & & 1549 & 1512 & 1502 & 1420 \\
\hline mol americas & cont & 16803 & 604 & 82 & 27.1 & in & $16-$ Sep & 1915 & & 1800 & 1730 & 1725 & 1645 \\
\hline jens maersk & cont & 30166 & 710 & 105.6 & 33.8 & in & 16-Sep & 2050 & & 1902 & 1836 & 1828 & 1750 \\
\hline cma cgm potomac & cont & 31154 & 705 & \begin{tabular}{|c|}
101.7 \\
\end{tabular} & 30.2 & in & 16-Sep & 2320 & & 2142 & 2104 & 2054 & 2005 \\
\hline zim israel & cont & 37204 & 754 & 105.6 & 27.6 & in & 17-Sep & 415 & & 242 & 203 & 149 & 55 \\
\hline msc christina & cont & 37579 & 745 & 105.9 & 32.25 & in & 17-Sep & 450 & & 314 & 230 & 222 & 130 \\
\hline mol elbe & cont & 50352 & 959 & 105.6 & 34 & in & 17-Sep & 505 & & 329 & 247 & 238 & 150 \\
\hline msc eleni & cont & 54881 & 932 & 137.8 & 36.25 & in & 17-Sep & 1055 & & 918 & 842 & 834 & 750 \\
\hline midnight sun & oil tanker & 27915 & 590 & 105.6 & 27.6 & in & 17-Sep & 1700 & 1600 & 1523 & 1447 & 1433 & 1335 \\
\hline darya rani & bulk & 26054 & 610 & 99.71 & 25.9 & in & 17-Sep & 1805 & 1642 & 1611 & 1535 & 1526 & 1430 \\
\hline alyona & cargo & 32226 & 674 & 101.7 & 26 & in & 17-Sep & 2355 & 2233 & 2156 & & 2102 & 2015 \\
\hline zim iberia & cont & 41507 & 833 & 105.9 & 33 & in & 18-Sep & 550 & 432 & 352 & 310 & 303 & 145 \\
\hline al mariyah & cont & 32534 & 694 & 105.9 & 28.7 & in & 18-Sep & 1125 & 1023 & 953 & 918 & 910 & 825 \\
\hline msc elena & cont & 30971 & 662 & 105.9 & 33.3 & in & 18-Sep & 1235 & 1130 & 1055 & 1020 & 1010 & 925 \\
\hline emmanuel tomasos & oil tanker & 23217 & 599 & 90.86 & 28 & in & 18-Sep & 1535 & 1444 & 1406 & 1326 & 1311 & 1215 \\
\hline hanjin wilmington & cont & 51754 & 950 & 105.6 & 34.4 & in & 18-Sep & 1755 & 1655 & 1627 & 1547 & 1540 & 1445 \\
\hline condor & cont & 14241 & 521 & 79.05 & 26.75 & in & 18-Sep & 1950 & 1850 & 1818 & 1742 & 1736 & 1650 \\
\hline Victoria Bridge & cont & 53400 & 965 & 105.6 & 36.1 & in & 18-Sep & 225 & 37 & 4 & 2320 & & 2200 \\
\hline essen express & cont & 53815 & 965 & 105.9 & 35.5 & in & 19-Sep & 710 & 538 & 509 & 430 & 424 & 330 \\
\hline kavo alexandros II & bulk & 16608 & 551 & 85.94 & 30 & in & 19-Sep & 915 & & 824 & 747 & 741 & 650 \\
\hline angel accord & bulk & 20212 & 581 & 93.15 & 23.1 & in & 19-Sep & 1820 & 1747 & 1714 & 1630 & 1620 & 1530 \\
\hline mol velocity & cont & 53519 & 965 & 105.9 & 30.5 & in & 19-Sep & 1945 & 1828 & 1758 & 1722 & 1715 & 1630 \\
\hline borc & gen cargo & 20139 & 531.5 & 88.56 & 35.2 & in & 19-Sep & 2040 & & 1930 & 1849 & 1840 & 1735 \\
\hline jervis bay & cont & 50350 & 959 & 105.9 & 30.6 & in & 19-Sep & 2150 & & 1944 & 1908 & 1901 & 1815 \\
\hline ismini & oil tanker & 37405 & 717 & 105.6 & 38 & in & 19-Sep & 2230 & 2117 & 2044 & 2010 & 2002 & 1905 \\
\hline stuttgart express & cont & 53815 & 965 & 105.9 & 37.6 & in & 19-Sep & 125 & 2356 & 2320 & 2246 & 2240 & 2150 \\
\hline aurora & tanker & 16454 & 528 & 91.84 & 22.8 & in & 20-Sep & 840 & & 718 & 642 & 635 & 555 \\
\hline cecile ericksen & bulk & 3461 & 373 & 50.84 & 20.5 & in & 20-Sep & 1125 & & 1035 & 959 & & 855 \\
\hline cp rome & cont & 26131 & 642 & 100 & 33.5 & in & 20-Sep & 2210 & 2123 & 2051 & & & 1930 \\
\hline ville de taurus & cont & 37549 & 850 & 105 & & in & 21-Sep & 415 & 306 & 225 & & & 30 \\
\hline onego spirit & bulk & 10490 & 469 & 72.16 & 22.3 & in & 21-Sep & 925 & & & & & 545 \\
\hline stolt capability & oil tanker & 24625 & 580 & 101.7 & 26.6 & in & 21-Sep & 1020 & 506 & & & & 730 \\
\hline msc insa & cont & 51608 & 868 & 105.9 & 37.7 & in & 21-Sep & 1235 & & & & & 915 \\
\hline hilli & $\operatorname{lng}$ & 96235 & 961 & 136.8 & 36.4 & in & 21-Sep & 1355 & & & & & 1100 \\
\hline besire kalkavan & cont & 9978 & 489 & 74.46 & 25.25 & in & 21-Sep & 45 & & & & & 2140 \\
\hline xin nan tong & cont & 41482 & 864 & 105.6 & 30.5 & in & 21-Sep & 250 & & & & & 2330 \\
\hline
\end{tabular}

$\mathrm{POB}=$ time pilot boards ship 
Table 3. Concluded.

\begin{tabular}{|c|c|c|c|c|c|c|c|c|c|c|c|c|c|}
\hline OUTBOUND:(SAIL) & & & & & & & & & & & & & \\
\hline Name & type & \begin{tabular}{|l|} 
gross \\
tonnage
\end{tabular} & $\begin{array}{l}\text { length, } \\
\mathrm{ft}\end{array}$ & \begin{tabular}{|l|} 
beam, \\
$\mathrm{ft}$
\end{tabular} & draft, $\mathrm{ft}$ & Direct & date & $\begin{array}{l}\text { POB } \\
\text { time }\end{array}$ & $\mathrm{CF}$ & CDF & FP & TI & \\
\hline schackenborg & Ro-ro & 14775 & 530 & 79.7 & 21.7 & out & 15-Sep & 140 & & & & & \\
\hline saimaagracht & gen cargo & 18231 & 608 & 82.98 & 22.1 & out & 15-Sep & 1830 & & 1958 & & & \\
\hline northern fortune & cont & 30509 & 664 & 102 & 34.75 & out & 15-Sep & 1900 & & 2049 & & & \\
\hline ANL georgia & cont & 40465 & 850 & 105.6 & 35.1 & out & 15-Sep & 1945 & & 2121 & & & \\
\hline general lee & gen cargo & 1614 & 206 & 50.18 & 9.5 & out & 15-Sep & 2035 & & 2130 & & & \\
\hline ym shanghai & cont & 40268 & 259 & 105.9 & 33.5 & out & 15-Sep & 2045 & & 2233 & & & \\
\hline cape bird & oil tanker & 25108 & 577 & 101.7 & 28 & out & 15-Sep & 2200 & & 2344 & & & \\
\hline khannur & Ing & 96235 & 961 & 136.8 & 37.1 & out & 16-Sep & 1220 & & & & 1323 & \\
\hline talisman & bulk? & 67140 & 790 & 99.38 & 30.8 & out & $16-$ Sep & 1655 & & 1745 & 1815 & 1828 & \\
\hline xin fang cheng & cont & 41482 & 861 & 105.9 & 31.8 & out & 16-Sep & 1825 & & 1934 & 2006 & 2019 & \\
\hline ym south & cont & 46697 & 904 & 105.6 & 36.75 & out & 16-Sep & 1905 & & 2042 & 2122 & 2131 & \\
\hline maersk garonne & cont & 50698 & 958 & 105.9 & 35.1 & out & 16-Sep & 1905 & & 2055 & 2135 & 2143 & \\
\hline star drivanger & gen cargo & 27735 & 600 & 101.7 & 29.3 & out & 16-Sep & 2035 & & 2126 & 2209 & 2219 & \\
\hline leyla kalkavan & cont & 9978 & 489 & 74.46 & 27.8 & out & 17-Sep & 110 & & 204 & 237 & 243 & \\
\hline new york express & cont & 54437 & 965 & 105.9 & 33.8 & out & 17-Sep & 135 & & 304 & 347 & 357 & \\
\hline star florida & gen cargo & 23345 & 615 & 96.76 & 22.7 & out & 17-Sep & 205 & & 322 & 358 & 407 & \\
\hline jens maersk & cont & 30166 & 710 & 105.6 & 33.5 & out & 17-Sep & 220 & & 342 & 425 & 433 & \\
\hline kyriakoula & oil tanker & 40680 & 755 & 105 & 27.7 & out & 17-Sep & 325 & & 514 & 601 & 612 & \\
\hline mol americas & cont & 16803 & 605 & 82 & 27.5 & out & $17-$ Sep & 600 & & 738 & 818 & 828 & \\
\hline sun right & cont & 53359 & 965 & 105 & 37.4 & out & 17-Sep & 740 & & 928 & 1007 & 1019 & \\
\hline cma cgm potomac & cont & 31154 & 705 & 101.7 & 35.4 & out & 17-Sep & 1025 & 1130 & 1200 & 1235 & 1245 & \\
\hline flintereems & gen cargo & 4503 & 367 & 49.2 & 15.4 & out & 17-Sep & 1230 & & 1256 & 1331 & 1338 & \\
\hline kochnev & gen cargo & 6030 & 371 & 62.98 & 25.6 & out & 17-Sep & 1330 & & 1506 & 1548 & 1556 & \\
\hline Jiang An Cheng & & 16703 & 571 & 83.97 & 32.8 & out & 17-Sep & 1510 & 1538 & 1606 & 1650 & 1701 & \\
\hline mol elbe & cont & 50352 & 959 & 105 & 33.25 & out & 17-Sep & 1810 & 1918 & 1950 & 2038 & 2044 & \\
\hline msc christina & cont & 37579 & 797 & 105.9 & 32.25 & out & 17-Sep & 1905 & 2007 & 2038 & 2113 & 2125 & \\
\hline zim israel & cont & 37204 & 775 & 105.6 & 27.6 & out & 17-Sep & 2100 & 2137 & 2205 & 2239 & 2250 & \\
\hline msc eleni & cont & 54881 & 932 & 137.8 & 35.75 & out & 17-Sep & 2345 & 42 & 106 & 140 & 147 & \\
\hline midnight sun & oil tanker & 27915 & 590 & 105.6 & 26.9 & out & 18-Sep & 1230 & 1328 & 1358 & 1435 & 1443 & \\
\hline \begin{tabular}{|l|} 
alyona \\
\end{tabular} & cargo & 32226 & 674 & 101.7 & 26.6 & out & 18-Sep & 1935 & 1944 & 2017 & 2104 & 2112 & \\
\hline zim iberia & cont & 41507 & 833 & 105.9 & 33.6 & out & 18-Sep & 1930 & 2033 & 2100 & 2140 & 2147 & \\
\hline darya rani & bulk & 26054 & 610 & 99.71 & 27.25 & out & 18-Sep & 2035 & 2043 & 2110 & 2152 & 2205 & \\
\hline sumida & cont & 13400 & 524 & 82 & 28.7 & out & 18-Sep & 2105 & 2158 & 2225 & 2304 & & \\
\hline \begin{tabular}{|l} 
al mariyah \\
.
\end{tabular} & cont & 32534 & 694 & 105.9 & 30.2 & out & 18-Sep & 2115 & 2212 & 2239 & 2315 & 2321 & \\
\hline msc elena & cont & 30971 & 662 & 105.9 & 33.4 & out & 19-Sep & 140 & $216 / 25$ & 318 & 350 & 359 & \\
\hline condor & cont & 14241 & 521 & 79.05 & 27.75 & out & 19-Sep & 1310 & 1353 & 1423 & 1452 & 1458 & \\
\hline \begin{tabular}{|l|} 
emanuelle tomasos \\
\end{tabular} & oil tanker & 23217 & 599 & 90.86 & 24.6 & out & 19-Sep & 1350 & 1426 & 1454 & 1527 & 1533 & \\
\hline nelson & bulk & 13677 & 508.5 & 75.11 & 17.7 & out & 19-Sep & 1745 & & 1855 & 1939 & 1948 & \\
\hline victoria bridge & cont & 53400 & 965 & 105.6 & 35.75 & out & 19-Sep & 1805 & 1910 & 1945 & 2041 & 2049 & \\
\hline hanjin wilmington & cont & 51754 & 950 & 105.6 & 35.75 & out & 19-Sep & 1905 & 2015 & 2118 & 2148 & 2156 & \\
\hline julia & oil tanker & 12165 & 518 & 73.14 & 30.3 & out & 20-Sep & 35 & & 140 & 222 & 229 & \\
\hline essen express & cont & 53815 & 965 & 105.9 & 36.4 & out & 20-Sep & 155 & 234 & 312 & 348 & 356 & \\
\hline mol velocity & cont & 53519 & 965 & 105.9 & 34.4 & out & 20-Sep & 740 & 836 & 918 & 957 & 1004 & \\
\hline kavo alexandros II & bulk & 16608 & 551 & 85.94 & 29.1 & out & 20-Sep & 910 & 938 & 1004 & 1046 & 1055 & \\
\hline angel accord & bulk & 20212 & 581 & 93.15 & 22.2 & out & 20-Sep & 1830 & 1913 & 1950 & & & \\
\hline stuttgart express & cont & 53815 & 965 & 105.9 & 40.1 & out & 20-Sep & 2005 & 2055 & 2150 & & & \\
\hline antares & gen cargo & 4793 & 571 & 83.97 & 14 & out & 20-Sep & 2215 & 2256 & 2314 & & & \\
\hline aurora & tanker & 16454 & 528 & 91.84 & 22.7 & out & 20-Sep & 2240 & 2256 & 2336 & & & \\
\hline jervis bay & cont & 50350 & 959 & 105.9 & 35.6 & out & 21-Sep & 30 & 124 & 157 & & & \\
\hline borc & gen cargo & 20139 & 531.5 & 88.56 & 19.25 & out & 21-Sep & 150 & & & & & \\
\hline cp rome & cont & 26131 & 642 & 100 & 33.8 & out & 21-Sep & 715 & & & & & \\
\hline ismini & oil tanker & 37405 & 717 & 105.6 & 28.6 & out & 21-Sep & 720 & & & & & \\
\hline cecile ericksen & bulk & 3461 & 373 & 50.84 & 16.5 & out & 21-Sep & 1350 & & & & & \\
\hline ville de taurus & cont & 37549 & 850 & 105 & 36.1 & out & 21-Sep & 1725 & & & & & \\
\hline msc insa & cont & 51608 & 868 & 105.9 & 37.3 & out & 21-Sep & 2000 & & & & & \\
\hline
\end{tabular}




\section{Pilot Interview}

As stated previously, ship speed is one of the most critical questions in a ship effects evaluation. Wilbur Wiggins of the Savannah District interviewed Master Captain Tommy Brown of the Savannah Bar Pilots using questions prepared by ERDC. The objective of these questions is to collect as much pertinent information as possible about ship operation in the existing and deepened channels.

1. What is the policy for running big ships (such as those with draft near design channel depths) and small ships (such as unloaded) relative to tide levels and direction of tides? Vessels have to be operated at a safe maneuvering speed but have to be run at a "competitive rate" - can't go slow (like 6 knots) - would take too much time to transit in and out of the harbor.

2. Of the 5 power levels of dead slow, slow, half, maneuver full, and full available to be used in ship transit, what power level is typically used in transiting the existing SH channel? Operates under maneuver full unless ship too powerful - have to use different speed for different ships - ship speed also varies by location in the harbor (faster in entrance channel to slow by city front) Does this power level vary with ship type and if so, what is the power level for each ship type? Power level varies - may run $17 \mathrm{knots}$ w/ powerful container vessels versus 12 knots for tankers and general cargo vessels.

3. What power level do you anticipate in the deepened channel with deeper draft vessels? About the same - possibly slower, depending on how each ship handles.

4. Where are areas along the channel where you tend to not run along the channel center line (because of channel alignment or other factors) and where do you run in each of those reaches? Normally run the center line of the channel unless meeting another vessel.

5. What are typical and maximum speeds in the existing channel for container ships? For tankers or bulk carriers? Container - 12 to 14 knots, tanker/ bulk 10-12 knots, not too powerful.

6. What will be typical and maximum speeds in the deepened channel for the different ship types? Should be about the same.

7. How does nighttime operation affect ship operation and ship speed? Does not affect. 
8. Are there other pertinent issues we have not raised that will help us understand ship operation and ship speed in existing and deepened channels? No.

9. After analysis of the ship transit data, it was apparent that few of the postPanamax ships were present during the field study to obtain both speed and ship effects data. Captain Brown was asked whether the speed of Panamax ships (for which substantial speed data was collected in the field study) differs from post Panamax ships in the existing channel. Captain Brown said he did not think that the speed would differ between Panamax and post-Panamax vessels.

From the pilot interview, the ship speeds of 12-14 knots are consistent with the speeds observed in the field study. The statement about use of maneuver full in both existing and deepened channels is consistent with other channels studied. 


\section{Ship Traffic Frequency}

Table 4 shows the characterization of the 6 ship types used in the Savannah District's analysis of future ship traffic including length, beam, and design draft. Table 5 shows the actual traffic distribution during the field study according to the six vessel types used in the traffic analysis. Each field study ship was placed in one of the six categories having beam closest to the actual beam. The average draft, beam, length, and actual tonnage are shown for the field study ships in each of the six categories in Table 5. Notice that the average draft of the field data ships in all but the Feedermax ship category is about 80 percent of the design draft.

Table 4. Classes of container ship traffic for Savannah Harbor.

\begin{tabular}{|l|l|l|l|}
\hline Vessel Type & Length, $\mathrm{ft}$ & Beam, ft & Design Draft, ft \\
\hline Post-Panamax & 1044 & 140 & 45.3 \\
\hline Panamax & 951 & 106 & 40.7 \\
\hline Sub-Panamax & 716.3 & 99.8 & 37.7 \\
\hline Handysize & 579.1 & 85.1 & 31.8 \\
\hline Feedermax & 427.5 & 67.7 & 25.2 \\
\hline Feeder & 344.7 & 56.1 & 20.0 \\
\hline
\end{tabular}

Table 5. Field study ships categorized according to vessel type used in Savannah District fleet forecast. Category based on ship beam.

\begin{tabular}{|c|c|c|c|c|c|c|}
\hline \multirow[b]{2}{*}{ Vessel, type } & \multirow[b]{2}{*}{$\begin{array}{l}\text { \# of ship } \\
\text { transits }\end{array}$} & \multicolumn{5}{|c|}{ Field Study Summary } \\
\hline & & $\begin{array}{l}\text { Range of } \\
\text { draft, } \mathrm{ft}\end{array}$ & $\begin{array}{l}\text { Average draft, } \mathrm{ft} \\
\text { (\% of design draft) }\end{array}$ & $\begin{array}{l}\text { Average } \\
\text { Beam, ft }\end{array}$ & $\begin{array}{l}\text { Average } \\
\text { Length, } \mathrm{ft}\end{array}$ & \begin{tabular}{|l} 
Tonnage of \\
average ship
\end{tabular} \\
\hline \begin{tabular}{|l|} 
Post- \\
Panamax
\end{tabular} & 5 & $35.8-37.1$ & $36.5(81)$ & 137.2 & 949 & $\begin{array}{l}114200 \\
(0.75)^{*}\end{array}$ \\
\hline Panamax & 49 & $26.9-40.1$ & $33.4(82)$ & 105.7 & 852 & $65300(0.68)$ \\
\hline \begin{tabular}{|l|} 
Sub- \\
Panamax
\end{tabular} & 16 & $22.2-35.4$ & $28.5(76)$ & 99.7 & 641 & $42200(0.72)$ \\
\hline Handysize & 18 & $14.0-35.2$ & $25.8(81)$ & 85.2 & 558 & $28800(0.73)$ \\
\hline Feedermax & 9 & $17.7-30.3$ & 24.1(96) & 71.4 & 469 & $18800(0.73)$ \\
\hline Feeder & 5 & $9.5-20.5$ & $16.4(82)$ & 50.1 & 337 & $7000(0.79)$ \\
\hline
\end{tabular}

Ship traffic is quantified by the number of calls with each call being equal to one inbound and one outbound transit. Based on the Savannah 
District's traffic analysis, the total number of calls will be the same for both without- and with-project for all traffic scenarios for any given year. For example, year 2030 has 4,030 calls and year 2050 has 7,801 calls for all traffic scenarios for both without- and with-project. Table 6 shows number of vessel calls for four traffic scenarios for future years 2030 and 2050. The four traffic scenarios are the Gulf Engineers and Consultants (GEC) forecast, GEC with 10 percent shift from Panamax (PA) to Post-Panamax (PP), GEC with 20 percent shift from PA to PP, and GEC with 30 percent shift from PA to PP. The only difference between the four scenarios is the number of PP and PA ships. The number of Sub-Panamax (SP), Handysize (HS), Feedermax (FM), and Feeder (F) ships do not change. In 2030, the total number of PP and PA ships is 3,544 for all four scenarios. In 2050 the total number of PP and PA ships is 7,009 for all four scenarios. To determine the change in traffic between the GEC and the percent shift scenarios, the specified percentage (such as 10 percent) of the total number of PP and PA ships is added to the number of PP ships and subtracted from the number of PA ships.

Table 6. Container ship traffic for Savannah Harbor. Numbers are for both without- and withproject. Values in () are percent of total calls.

\begin{tabular}{|c|c|c|c|c|c|c|c|c|}
\hline \multirow[b]{2}{*}{ Vessel Type } & \multicolumn{2}{|c|}{ GEC } & \multicolumn{2}{|c|}{$10 \%$ Increase } & \multicolumn{2}{|c|}{$20 \%$ Increase } & \multicolumn{2}{|c|}{$30 \%$ Increase } \\
\hline & 2030 & 2050 & 2030 & 2050 & 2030 & 2050 & 2030 & 2050 \\
\hline $\begin{array}{l}\text { Post- } \\
\text { Panamax }\end{array}$ & $\begin{array}{r}211 \\
(5.2)\end{array}$ & $\begin{array}{r}291 \\
(3.7)\end{array}$ & $\begin{array}{r}565 \\
(14.0)\end{array}$ & $\begin{array}{r}992 \\
(12.7)\end{array}$ & $\begin{array}{r}920 \\
(22.8)\end{array}$ & $\begin{array}{l}1,693 \\
(21.7)\end{array}$ & $\begin{array}{l}1,274 \\
(31.6)\end{array}$ & $\begin{array}{l}2,394 \\
(30.7)\end{array}$ \\
\hline Panamax & $\begin{array}{l}3,333 \\
(82.7)\end{array}$ & $\begin{array}{l}6,718 \\
(86.1)\end{array}$ & $\begin{array}{l}2,979 \\
(73.9)\end{array}$ & $\begin{array}{l}6,017 \\
(77.1)\end{array}$ & $\begin{array}{l}2,624 \\
(65.1)\end{array}$ & $\begin{array}{l}5,316 \\
(68.1)\end{array}$ & $\begin{array}{l}2,270 \\
(56.3)\end{array}$ & $\begin{array}{l}4,615 \\
(59.2)\end{array}$ \\
\hline Sub-Panamax & $\begin{array}{l}252 \\
(6.3)\end{array}$ & $\begin{array}{l}458 \\
(5.9)\end{array}$ & $\begin{array}{r}252 \\
(6.3)\end{array}$ & $\begin{array}{r}458 \\
(5.9) \\
\end{array}$ & $\begin{array}{r}252 \\
(6.3) \\
\end{array}$ & $\begin{array}{r}458 \\
(5.9) \\
\end{array}$ & $\begin{array}{r}252 \\
(6.3) \\
\end{array}$ & $\begin{array}{r}458 \\
(5.9) \\
\end{array}$ \\
\hline Handysize & $\begin{array}{r}215 \\
(5.3)\end{array}$ & $\begin{array}{r}315 \\
(4.0)\end{array}$ & $\begin{array}{r}215 \\
(5.3)\end{array}$ & $\begin{array}{r}315 \\
(4.0)\end{array}$ & $\begin{array}{r}215 \\
(5.3)\end{array}$ & $\begin{array}{r}315 \\
(4.0)\end{array}$ & $\begin{array}{r}215 \\
(5.3)\end{array}$ & $\begin{array}{r}315 \\
(4.0)\end{array}$ \\
\hline Feedermax & $\begin{array}{r}18 \\
(0.4)\end{array}$ & $\begin{array}{r}18 \\
(0.2)\end{array}$ & $\begin{array}{r}18 \\
(0.4)\end{array}$ & $\begin{array}{r}18 \\
(0.2)\end{array}$ & $\begin{array}{r}18 \\
(0.4)\end{array}$ & $\begin{array}{r}18 \\
(0.2)\end{array}$ & $\begin{array}{r}18 \\
(0.4)\end{array}$ & $\begin{array}{r}18 \\
(0.2)\end{array}$ \\
\hline Feeder & $\begin{array}{r}1 \\
(0.00)\end{array}$ & $\begin{array}{r}1 \\
(0.00)\end{array}$ & $\begin{array}{r}1 \\
(0.00)\end{array}$ & $\begin{array}{r}1 \\
(0.00)\end{array}$ & $\begin{array}{r}1 \\
(0.00)\end{array}$ & $\begin{array}{r}1 \\
(0.00)\end{array}$ & $\begin{array}{r}1 \\
(0.00)\end{array}$ & $\begin{array}{r}1 \\
(0.00)\end{array}$ \\
\hline Total Calls & 4,030 & 7,801 & 4,030 & 7,801 & 4,030 & 7,801 & 4,030 & 7,801 \\
\hline
\end{tabular}

The vessel effect comparisons presented herein are for without-project versus with-project conditions for the years 2030 and 2050. Two draft conditions will be used in the analysis as follows: a) design draft and b) 80 percent of design draft as found during the field study. The only difference between the without-project and with-project traffic is the draft 
of the PP ships and the speed that ships will travel in the existing versus future deepened channel. All other ships, including Panamax, can draft their design draft in the without-project (existing) channel. In the withoutproject (existing) channel, PP ships are limited to $40.7 \mathrm{ft}$ of draft compared to $45.3 \mathrm{ft}$ in the with-project (deepened) channel. The comparisons of without- to with-project will use a typical power setting and thus typical speed determined from the field study. Without- and with-project will also be compared using a higher power and thus, higher ship speed. As will be shown subsequently, the typical speed in the with-project deepened channel is slightly greater than the typical speed in the without-project existing channel. In the same manner, the high speed in the with-project deepened channel is slightly greater than the high speed in the withoutproject existing channel. 


\section{$5 \quad$ Ship Speed Analysis}

Ship speed in the Savannah Harbor field study was determined several ways. First, team observers were present during daylight hours at the Coast Guard (CG) Station for several days during the study. Using a stopwatch, the time required for the bow and stern of the ship to pass a fixed point on the horizon was used with overall ship length to determine ship speed. In a similar manner, the cameras were used to determine passage time for bow to stern at a fixed point on the screen and this differential time was used with overall ship length to determine ship speed. Bow to stern passage time is a reliable means of determining ship speed. The low-light cameras were used in this study to try to use the bow to stern time differential for nighttime ship passage. The low light cameras resulted in limited success because identifying the precise location of the bow and stern remained difficult even with the low light cameras. This technique works best when there are various small light sources in the background that go off and on as the ship blocks the light sources. While numerous lights were present at $\mathrm{CF}$ and some lights were present north of the TI camera, none were present at FP, and too much light was present at CDF from the Liquid Natural Gas facility on the south side of the channel.

Another speed technique that can be used at night with the cameras is to determine the field of view width of the screen and use the time of passage across the screen to determine ship speed. This worked well at TI because the camera was 4,500 ft away from the channel and with the amount of camera zoom used, the angle of the field of view at TI was about 22 deg and view width at the channel center line was about 1,730 ft. By having a small angle in the screen width, the errors that arise from the ship not being on the channel center line are small. At FP, the view angle was $27 \mathrm{deg}$, which was also adequate. At CDF, the channel and camera were close together, which required a wide camera zoom and resulted in about a 68-deg angle of the field of view. The extreme width of angle causes significant errors in speed for ships not on the channel center line. The final method to determine ship speed is to use the time of ship passage at two points along the channel with their distance apart to determine an average speed over the reach. Time of passage at either end of the reach can be obtained from cameras, capacitance gages, or pressure cells that measure ship effects with the exception of the capacitance gages at TI 
because of their large distance from the channel. The reach average technique was used from TI to FP (10,070 ft apart), FP to CDF $(44,400 \mathrm{ft}$ apart), and CDF to $\mathrm{CF}(28,700 \mathrm{ft}$ apart). In this study, daytime passage with operating cameras always used bow to stern time from the camera. Nighttime passage with operating cameras used bow to stern at CF, CDF, and FP. Nighttime passage with operating cameras at TI used field of view width. When cameras were not operating, only average reach speeds could be determined and the capacitance gages and pressure cells provided time of passage. Table 7 shows the speeds determined for each ship in the study.

Figures 10 and 11 show inbound and outbound ship speeds relative to ground along the project reach. Speeds are summarized in Table 8. Both directions show speed decreasing toward $\mathrm{CF}$ and decreased speed at the Coast Guard dock that is close to the pilot's dock. Inbound ships show the speed has decreased by up to 1.5 knots between the FP and the Coast Guard. Outbound ships show the speed has increased by up to 1.5 knots between the Coast Guard and FP. The FP camera speed is about equal to the average reach speed between $\mathrm{CDF}$ and FP. The average reach speed from $\mathrm{CDF}$ to FP is somewhat misleading because the camera speeds on each end of the CDF-FP reach are generally less than the average along the reach. Only one explanation is possible; the ship was going faster than the reach average over a significant portion of the reach. Based on the data, inbound and outbound speeds are similar. 
Table 7. Ship log with speeds for each ship.

\begin{tabular}{|c|c|c|c|c|c|c|c|c|c|c|}
\hline Name & Dir & Day & $\begin{array}{c}\text { CF } \\
\text { camera } \\
\text { speed, } \\
\text { knots }\end{array}$ & $\begin{array}{l}\text { CF - CDF } \\
\text { average } \\
\text { speed, } \\
\text { knots }\end{array}$ & $\begin{array}{c}\text { CDF } \\
\text { camera } \\
\text { speed, } \\
\text { knots }\end{array}$ & $\begin{array}{l}\text { CDF - FP } \\
\text { average } \\
\text { speed, } \\
\text { knots }\end{array}$ & $\begin{array}{c}\text { CG } \\
\text { observation } \\
\text { team speed, } \\
\text { knots }\end{array}$ & $\begin{array}{c}\text { FP } \\
\text { camera } \\
\text { speed, } \\
\text { knots }\end{array}$ & $\begin{array}{c}\text { FP - TI } \\
\text { average } \\
\text { speed, } \\
\text { knots }\end{array}$ & $\begin{array}{c}\text { TI camera } \\
\text { speed, } \\
\text { knots }\end{array}$ \\
\hline \multicolumn{11}{|l|}{ INBOUND: } \\
\hline flintereems & in & 15 & & & 8.7 & & & & & \\
\hline khannur & in & 15 & & & & & & & & \\
\hline maersk garonne & in & 15 & & & 9.0 & & & & & \\
\hline ym south & in & 15 & & & 6.9 & & & & & \\
\hline Jiang An Cheng & in & 15 & & & 6.8 & & & & & \\
\hline leyla kalkavan & in & 15 & & & 4.6 & & & & & \\
\hline xin fang cheng & in & 16 & & & 8.4 & & & & & \\
\hline new york express & in & 16 & & & 7.7 & & & & & \\
\hline kyriakoula & in & 16 & & & & & & & & \\
\hline sun right & in & 16 & & & 11.7 & 11.7 & & & 12.3 & 15.1 \\
\hline mol americas & in & 16 & & & 5.0 & 15.0 & 13.8 & 13.8 & 12.6 & 15.6 \\
\hline jens maersk & in & 16 & & & 13.6 & 16.1 & & & 13.2 & 16.3 \\
\hline cma cgm potomac & in & 16 & & & 12.3 & 11.1 & & & 11.7 & 13.0 \\
\hline zim israel & in & 17 & & & 5.5 & 10.1 & & & 9.7 & 10.9 \\
\hline msc christina & in & 17 & & & 7.4 & 10.1 & & & 11.6 & 13.0 \\
\hline mol elbe & in & 17 & & & 8.9 & 10.8 & & & 8.8 & 12.1 \\
\hline msc eleni & in & 17 & & & 10.4 & 12.0 & & & 11.0 & 14.2 \\
\hline midnight sun & in & 17 & 5.63 & 7.8 & 10.6 & 10.5 & 9.3 & & 10.7 & 10.3 \\
\hline darya rani & in & 17 & 6.70 & 9.2 & 9.5 & 11.7 & 11.6 & & 12.4 & 12.0 \\
\hline alyona & in & 17 & 7.41 & 7.8 & 7.4 & 10.7 & & & 8.0 & 11.6 \\
\hline zim iberia & in & 18 & 5.16 & 7.1 & 6.9 & 10.4 & & & 11.1 & 11.3 \\
\hline al mariyah & in & 18 & 6.52 & 9.5 & 10.8 & 12.2 & 8.3 & & 13.5 & 13.7 \\
\hline msc elena & in & 18 & 5.75 & 8.2 & 10.9 & 11.9 & 8.0 & & 14.4 & 13.5 \\
\hline emmanuel tomasos & in & 18 & 5.28 & 7.4 & 8.9 & 9.8 & 4.4 & & 7.9 & 9.4 \\
\hline hanjin wilmington & in & 18 & 6.64 & 9.1 & 10.3 & 10.9 & 9.1 & 10.4 & 11.2 & 11.7 \\
\hline condor & in & 18 & 8.12 & 8.7 & 12.3 & 12.6 & 10.0 & 14.1 & 16.5 & 18.1 \\
\hline Victoria Bridge & in & 18 & 6.34 & 8.1 & 8.3 & 10.6 & & 9.8 & & \\
\hline essen express & in & 19 & 6.52 & 9.4 & 11.4 & 12.1 & & 9.5 & 12.1 & 12.1 \\
\hline kavo alexandros II & in & 19 & & & 9.6 & 12.2 & 10.7 & 13.0 & 14.1 & 14.2 \\
\hline angel accord & in & 19 & & 8.4 & 9.3 & $\begin{array}{l}+10.1 \\
10.1\end{array}$ & 9.8 & 10.1 & 10.3 & 11.1 \\
\hline mol velocity & in & 19 & & 9.1 & 12.5 & 12.5 & 9.5 & 10.4 & 12.8 & 15.5 \\
\hline borc & in & 19 & & & 8.8 & 10.8 & & 10.8 & 11.6 & 11.3 \\
\hline jervis bay & in & 19 & & & 10.1 & 12.0 & & 11.9 & 14.1 & 14.3 \\
\hline ismini & in & 19 & & 8.4 & 9.9 & 13.2 & & 12.9 & 15.5 & 12.2 \\
\hline stuttgart express & in & 19 & & 7.5 & 11.0 & 13.5 & & $\begin{array}{l}12.7 \\
12.7\end{array}$ & 14.3 & 15.2 \\
\hline aurora & in & 20 & & & 10.8 & 12.2 & & 10.4 & & \\
\hline cecile ericksen & in & 20 & & & 11.1 & 11.7 & 10.4 & 11.6 & & \\
\hline cp rome & in & 20 & 9.72 & 9.0 & 11.6 & & & & & \\
\hline ville de taurus & in & 21 & 5.93 & 6.7 & 8.7 & & & & & \\
\hline onego spirit & in & 21 & & & & & & & & \\
\hline stolt capability & in & 21 & 11.44 & & & & & & & \\
\hline msc insa & in & 21 & & & & & & & & \\
\hline hilli & in & 21 & & & & & & & & \\
\hline besire kalkavan & in & 21 & & & & & & & & \\
\hline xin nan tong & in & 21 & & & & & & & & \\
\hline
\end{tabular}

$C G=$ Coast Guard 
Table 7. Concluded.

\begin{tabular}{|c|c|c|c|c|c|c|c|c|c|c|}
\hline \multicolumn{11}{|l|}{ OUTBOUND:(SAIL) } \\
\hline schackenborg & out & 15 & & & & & & & & \\
\hline saimaagracht & out & 15 & & & 5.3 & & & & & \\
\hline northern fortune & out & 15 & & & 5.3 & & & & & \\
\hline ANL georgia & out & 15 & & & 6.3 & & & & & \\
\hline general lee & out & 15 & & & 5.8 & & & & & \\
\hline ym shanghai & out & 15 & & & 6.6 & & & & & \\
\hline cape bird & out & 15 & & & 5.0 & & & & & \\
\hline khannur & out & 16 & & & & & & & & 11.1 \\
\hline talisman & out & 16 & & & 10.8 & 11.0 & & & 11.7 & 14.2 \\
\hline xin fang cheng & out & 16 & & & 12.5 & 13.5 & & & 7.7 & 14.2 \\
\hline ym south & out & 16 & & & 8.8 & 11.3 & & & 10.3 & 12.2 \\
\hline maersk garonne & out & 16 & & & 9.2 & 11.1 & & & 11.8 & 13.5 \\
\hline star drivanger & out & 16 & & & 6.3 & 10.0 & & & 10.7 & 11.9 \\
\hline leyla kalkavan & out & 17 & & & 10.7 & 14.6 & & & 11.5 & 13.8 \\
\hline new york express & out & 17 & & & 9.7 & 10.0 & & & 11.0 & 11.3 \\
\hline star florida & out & 17 & & & 10.7 & 12.2 & & & 10.8 & 11.7 \\
\hline jens maersk & out & 17 & & & 10.6 & 10.5 & & & 15.6 & 12.7 \\
\hline kyriakoula & out & 17 & & & 7.6 & 9.7 & & & 9.8 & 10.9 \\
\hline mol americas & out & 17 & & & 11.6 & 11.6 & & & 11.4 & 14.3 \\
\hline sun right & out & 17 & & & 9.7 & 11.2 & 10.4 & $10.7 \mathrm{~W}$ & 12.6 & 14.3 \\
\hline cma cgm potomac & out & 17 & & & 11.6 & 12.9 & 10.5 & $11.0 \mathrm{~A}$ & 13.3 & 14.9 \\
\hline flintereems & out & 17 & & & 11.4 & 12.7 & 12.0 & $12.5 \mathrm{~A}$ & 13.0 & 12.1 \\
\hline kochnev & out & 17 & & & 11.0 & 10.8 & 9.6 & $10.0 \mathrm{~A}$ & 10.8 & 10.5 \\
\hline Jiang An Cheng & out & 17 & 6.6 & 9.8 & 9.7 & 10.1 & 8.7 & $10.0 \mathrm{~A}$ & 10.6 & 10.6 \\
\hline mol elbe & out & 17 & 5.2 & 8.7 & 10.0 & 12.5 & & & $\begin{array}{ll}11.6 \\
\end{array}$ & 11.9 \\
\hline msc christina & out & 17 & 6.0 & 9.0 & 8.0 & & & & & 12.7 \\
\hline zim israel & out & 17 & 8.1 & 9.8 & 10.7 & 13.2 & & & 10.4 & 13.9 \\
\hline msc eleni & out & 17 & 7.1 & 10.8 & 10.3 & 13.0 & & & 14.4 & 13.3 \\
\hline midnight sun & out & 18 & 6.6 & 9.8 & $10.3 \mathrm{~W}$ & 11.9 & 10.6 & $10.6 \mathrm{~A}$ & 11.4 & 13.0 \\
\hline zim iberia & out & 18 & 8.1 & 8.1 & 7.5 & 9.7 & & 12.3 & \begin{tabular}{l|l}
13.3 \\
\end{tabular} & 13.0 \\
\hline alyona & out & 18 & 6.2 & 10.6 & 7.8 & 11.2 & & 10.3 & 11.0 & 10.1 \\
\hline darya rani & out & 18 & 8.2 & 10.2 & 7.2 & & & & & 11.3 \\
\hline sumida & out & 18 & 6.8 & 10.1 & 7.8 & 12.2 & & 12.0 & & \\
\hline al mariyah & out & 18 & 7.0 & 10.8 & 9.0 & 11.9 & & 13.3 & 14.4 & 13.8 \\
\hline msc elena & out & 19 & 7.8 & 11.9 & 10.9 & 12.4 & & 12.3 & 13.5 & 11.9 \\
\hline condor & out & 19 & 7.7 & 9.8 & $14.7 \mathrm{~W}$ & 14.6 & 13.5 & 12.9 & 14.5 & 16.2 \\
\hline emanuelle tomasos & out & 19 & 7.2 & 10.0 & $12.3 \mathrm{~W}$ & 13.9 & 13.5 & $14.2 \mathrm{~W}$ & 15.2 & 16.1 \\
\hline nelson & out & 19 & & & 9.4 & 9.9 & & 10.0 & $\mid 10.7$ & 10.4 \\
\hline victoria bridge & out & 19 & 6.4 & 5.8 & 7.7 & 9.7 & & 9.5 & 10.9 & 11.2 \\
\hline hanjin wilmington & out & 19 & 2.4 & & & & & 14.8 & 14.5 & 12.5 \\
\hline julia & out & 20 & & & 7.0 & 10.9 & & 11.4 & \begin{tabular}{|c|}
12.5 \\
\end{tabular} & 10.6 \\
\hline essen express & out & 20 & & 7.6 & 9.1 & 11.6 & & 11.7 & \begin{tabular}{|c|}
13.5 \\
\end{tabular} & 11.9 \\
\hline mol velocity & out & 20 & & 6.7 & $10.8 \mathrm{~W}$ & 11.2 & 9.9 & $11.7 \mathrm{~W}$ & 12.7 & 13.3 \\
\hline kavo alexandros II & out & 20 & & & 9.6 & 9.9 & 9.4 & $9.9 \mathrm{~W}$ & 11.0 & 11.3 \\
\hline angel accord & out & 20 & 6.9 & 7.9 & $10.1 \mathrm{~W}$ & & & & & \\
\hline stuttgart express & out & 20 & 5.4 & 5.3 & 6.8 & & & & & \\
\hline antares & out & 20 & & & & & & & & \\
\hline aurora & out & 20 & & & & & & & & \\
\hline jervis bay & out & 21 & 8.1 & 8.8 & 9.5 & & & & & \\
\hline borc & out & 21 & & & 8.2 & & & & & \\
\hline cp rome & out & 21 & & & & & & & & \\
\hline ismini & out & 21 & & & & & & & & \\
\hline cecile ericksen & out & 21 & & & & & & & & \\
\hline ville de taurus & out & 21 & & & & & & & & \\
\hline msc insa & out & 21 & & & & & & & & \\
\hline & & & $\bar{V}=\mathrm{s}$ & in $n$ & lysis & $\begin{array}{l}A=\text { ship used } \\
\text { Coast Guard }\end{array}$ & $\begin{array}{l}d \text { in wave analys } \\
d \text { and adjacent }\end{array}$ & $\begin{array}{l}\text { but speed } \\
\text { ach averag }\end{array}$ & $\begin{array}{l}\text { d adopted fro } \\
\text { ged speeds. }\end{array}$ & \\
\hline
\end{tabular}




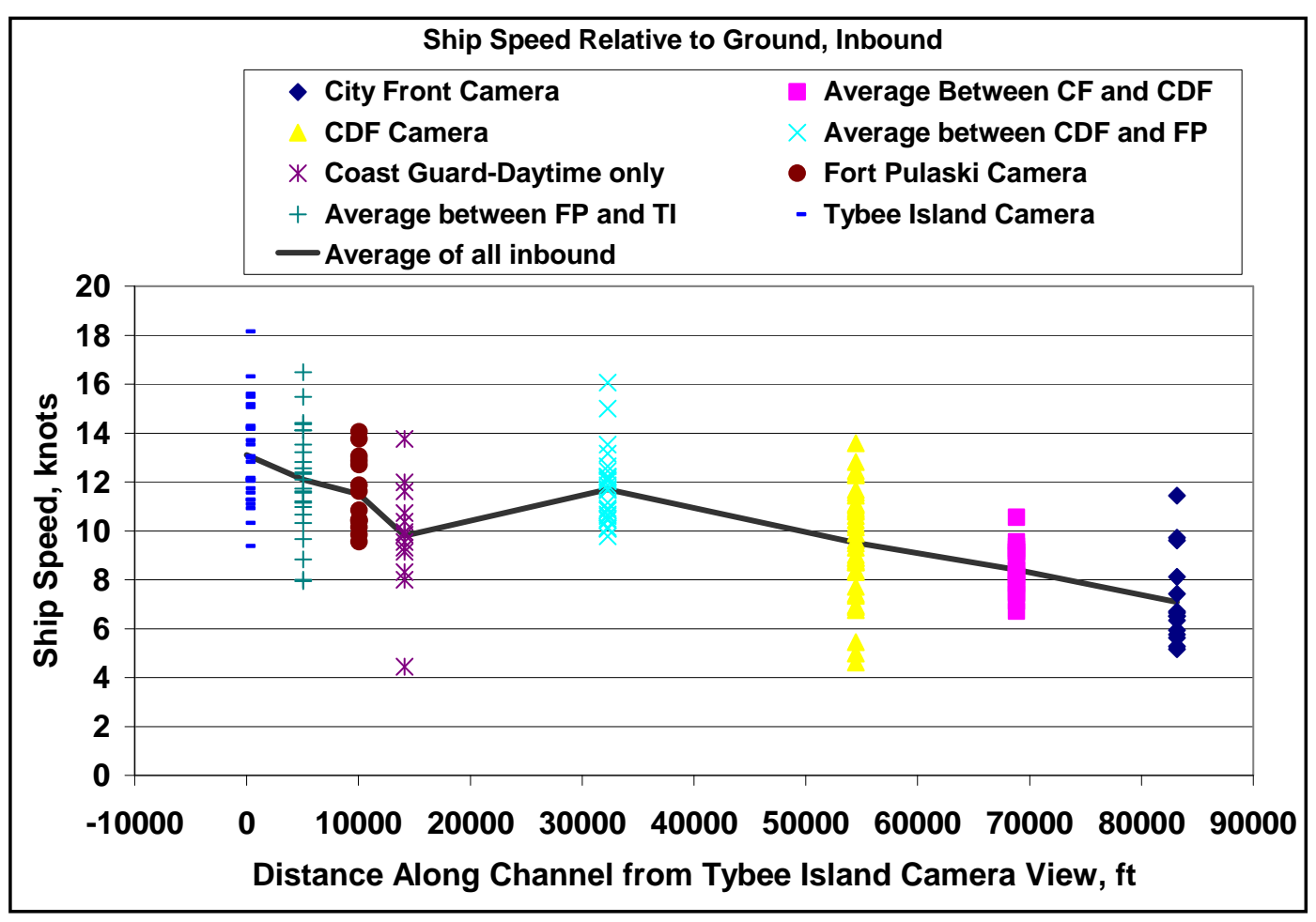

Figure 10. Ship speed along reach for inbound ships.

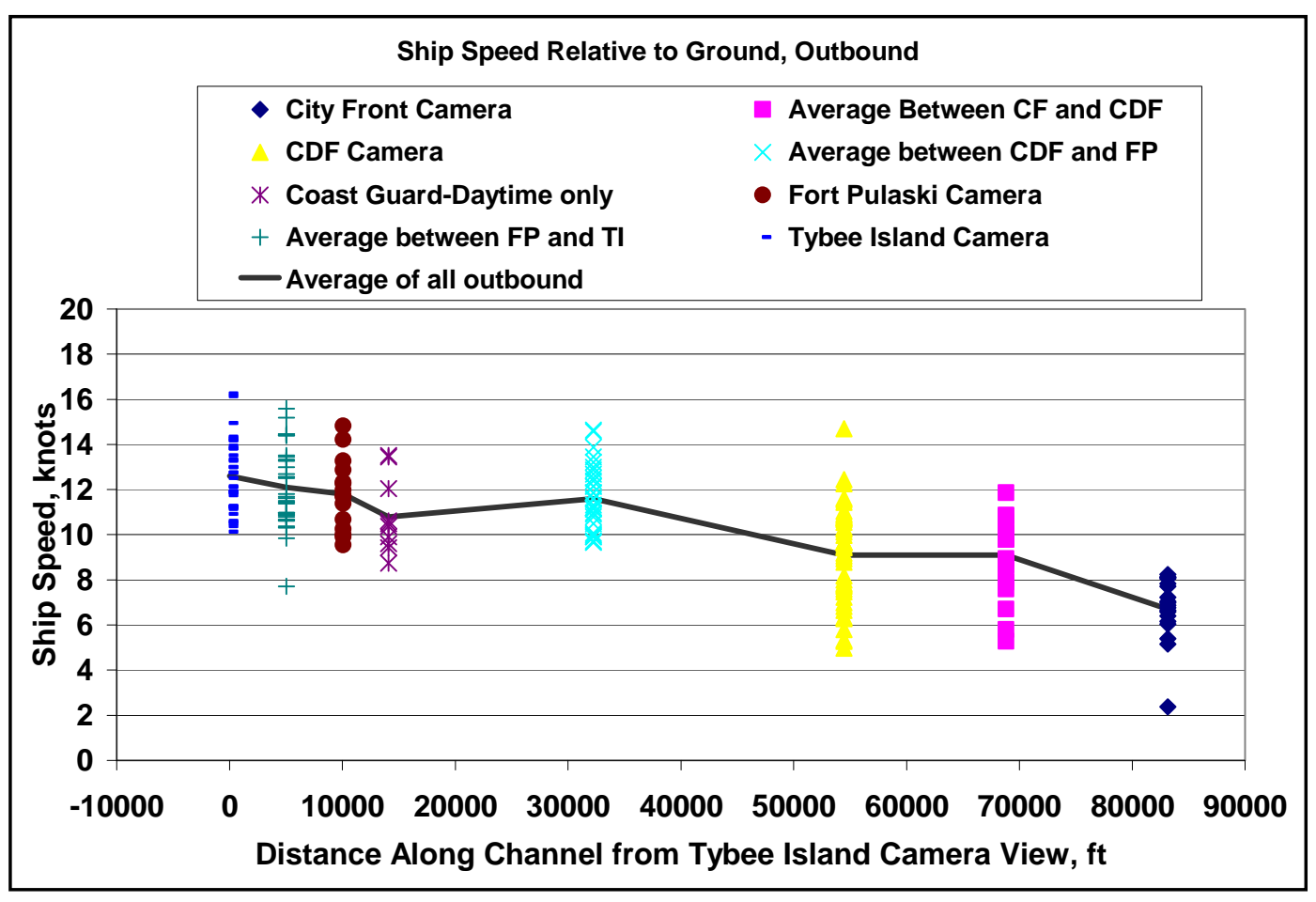

Figure 11. Ship speed along reach for outbound ships. 
Table 8. Summary of ship speeds along channel from field study.

\begin{tabular}{|l|l|l|l|l|l|l|}
\hline Location & Speed Type & $\begin{array}{l}\text { Inbound, } \\
\text { knots }\end{array}$ & $\begin{array}{l}\text { Outbound, } \\
\text { knots }\end{array}$ & $\begin{array}{l}\text { Day, } \\
\text { knots }\end{array}$ & $\begin{array}{l}\text { Night, } \\
\text { knots }\end{array}$ & $\begin{array}{l}\text { Overall Average, } \\
\text { knots }\end{array}$ \\
\hline City Front & Camera & 7.1 & 6.7 & NA & NA & 6.9 \\
\hline $\begin{array}{l}\text { CF to } \\
\text { CDF }\end{array}$ & $\begin{array}{l}\text { Reach } \\
\text { average }\end{array}$ & 8.4 & 9.1 & NA & NA & 8.8 \\
\hline CDF & Camera & 9.5 & 9.1 & 10.5 & 8.4 & 9.3 \\
\hline CDF to FP & $\begin{array}{l}\text { Reach } \\
\text { average }\end{array}$ & 11.7 & 11.6 & 11.8 & 11.5 & 11.7 \\
\hline CG & Observers & 9.8 & 10.8 & 10.3 & NA & 10.3 \\
\hline FP & Camera & 11.5 & 11.8 & 11.6 & 11.7 & 11.7 \\
\hline FP to TI & $\begin{array}{l}\text { Reach } \\
\text { average }\end{array}$ & 12.1 & 12.1 & 12.2 & 11.9 & 12.1 \\
\hline TI & Camera & 13.1 & 12.6 & 13.2 & 12.4 & 12.9 \\
\hline
\end{tabular}

The speeds were also analyzed for differences between night and daytime speeds as shown in Table 8. Data show a tendency for lesser nighttime speeds, but it should be noted that nighttime speeds are generally the least accurate because of the greater uncertainty in the location of the bow and stern when using cameras. The data were also analyzed for effects of ship size on ship speed. A simple relation describing ship size is an estimate of the actual tonnage equal to (product of the length, beam, and draft) $\times$ block coefficient $\left(\mathrm{C}_{\mathrm{b}}\right) \times$ weight of water/ 2,000 lb per ton. Since block coefficient is not known for all ships, the Permanent International Association of Navigation Congresses (PIANC) table for typical ship dimensions and $\mathrm{C}_{\mathrm{b}}$ was used to identify the appropriate $\mathrm{C}_{\mathrm{b}}$. This actual tonnage estimate is plotted against ship speed for the various locations along the channel in Figures 12 to 18. The data show a small increase in speed for decreasing ship size at $\mathrm{CF}$ camera and $\mathrm{CF}-\mathrm{CDF}$ average which likely reflects the confined and congested area in the vicinity of $\mathrm{CF}$ that could have a greater influence on larger ships. At CDF and all locations downstream, variation of speed with ship size is not significant. 


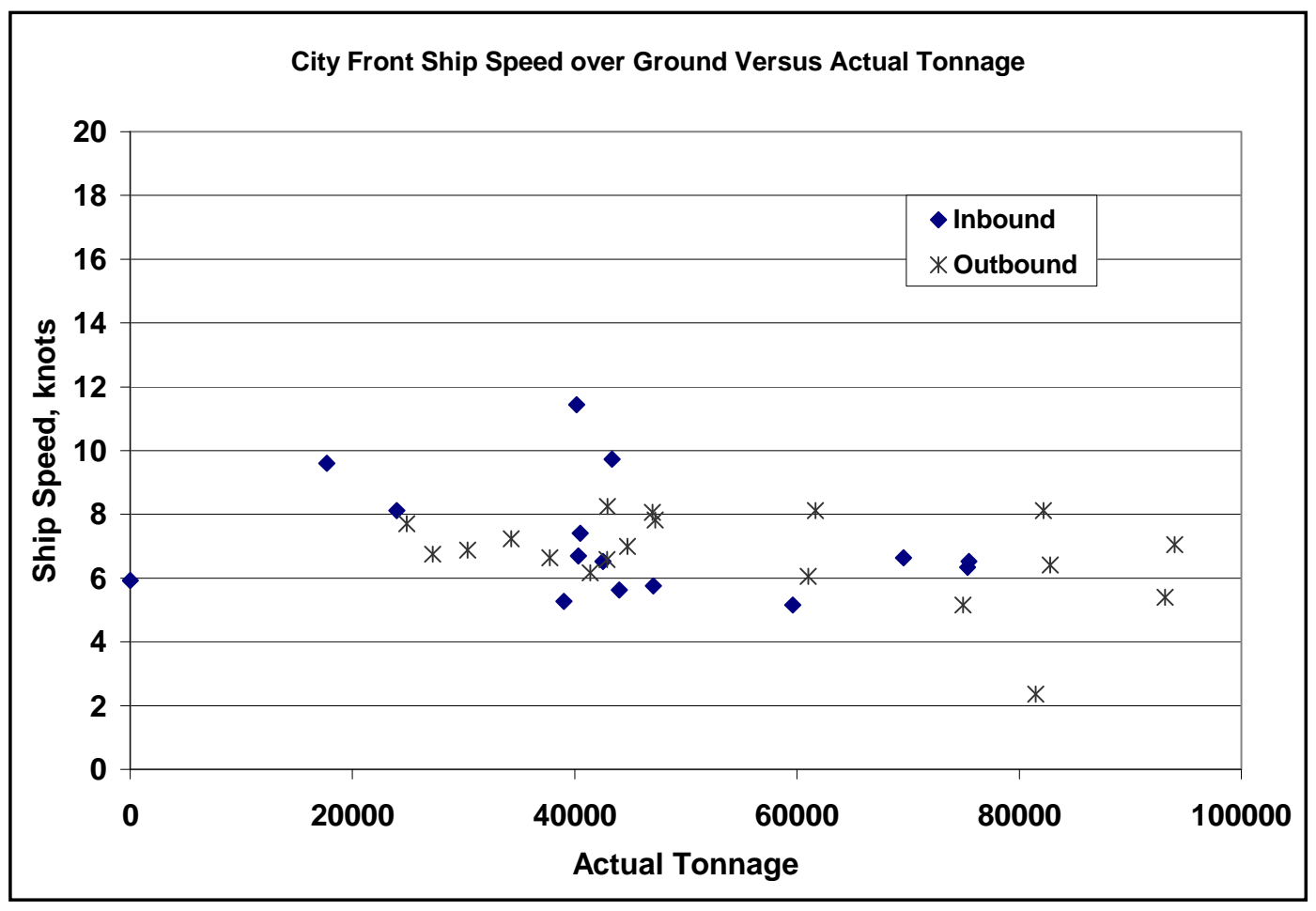

Figure 12. Ship speed versus ship size at City Front.

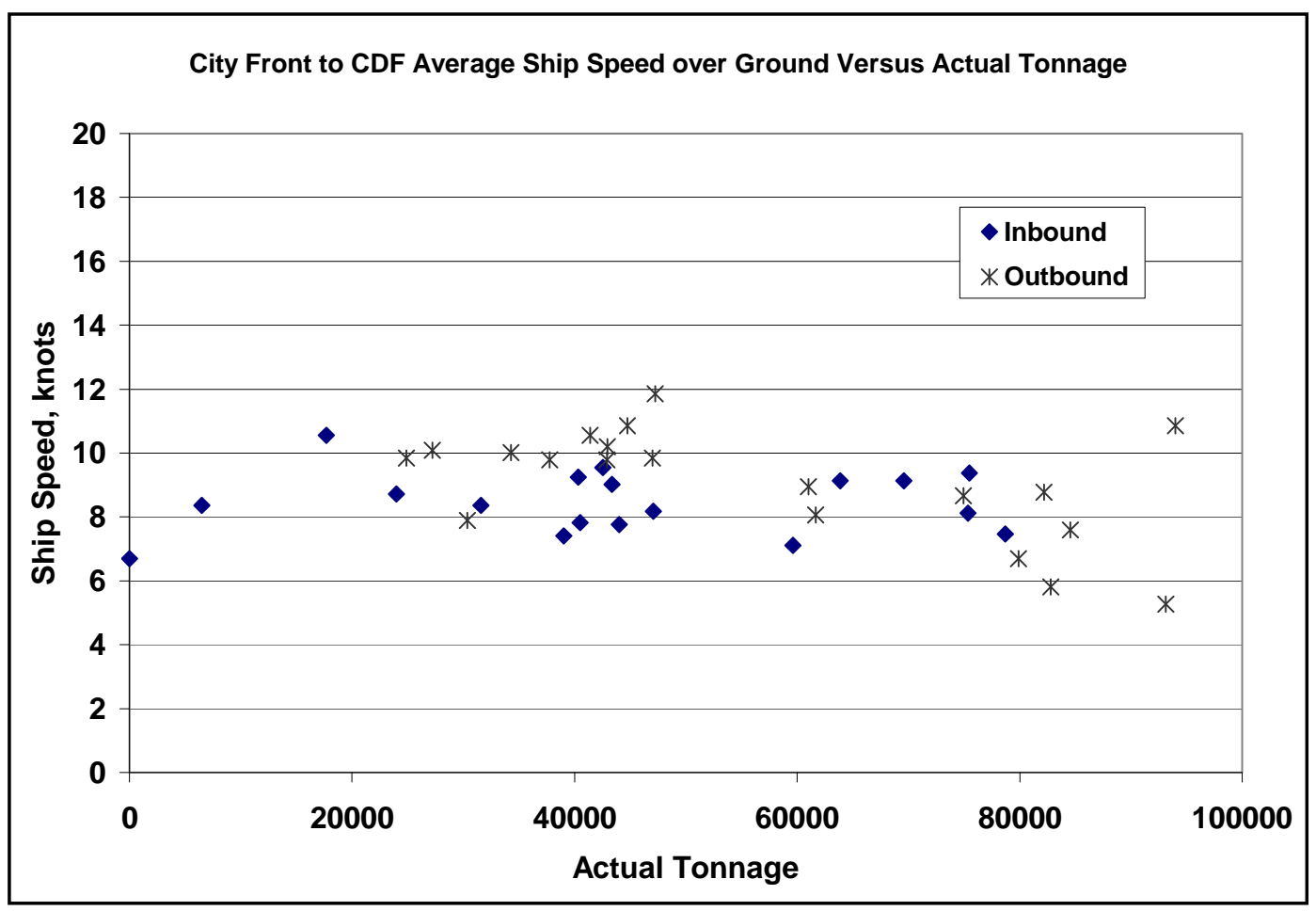

Figure 13. Ship speed versus ship size averaged over CF to CDF reach. 


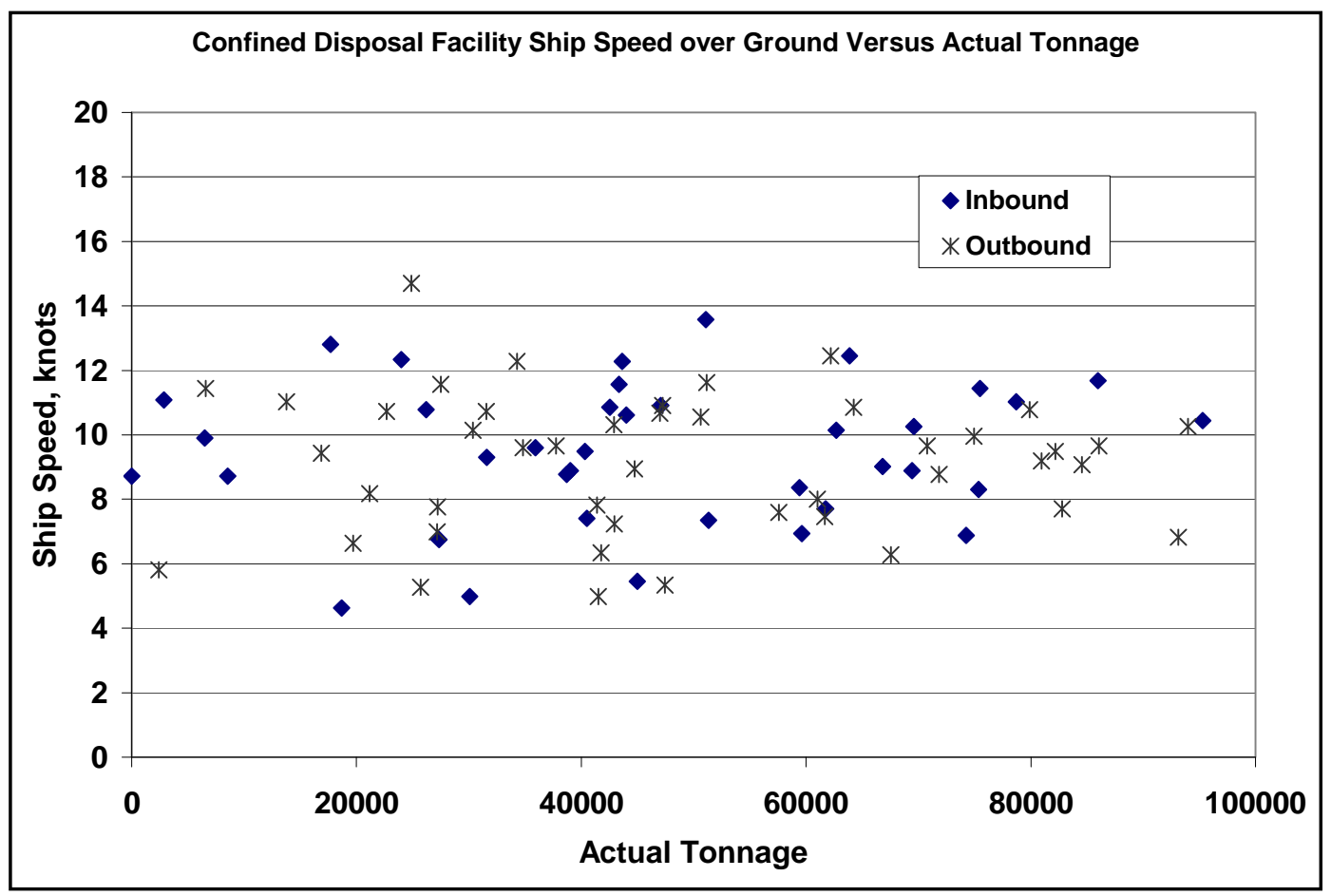

Figure 14. Ship speed versus ship size at CDF camera.

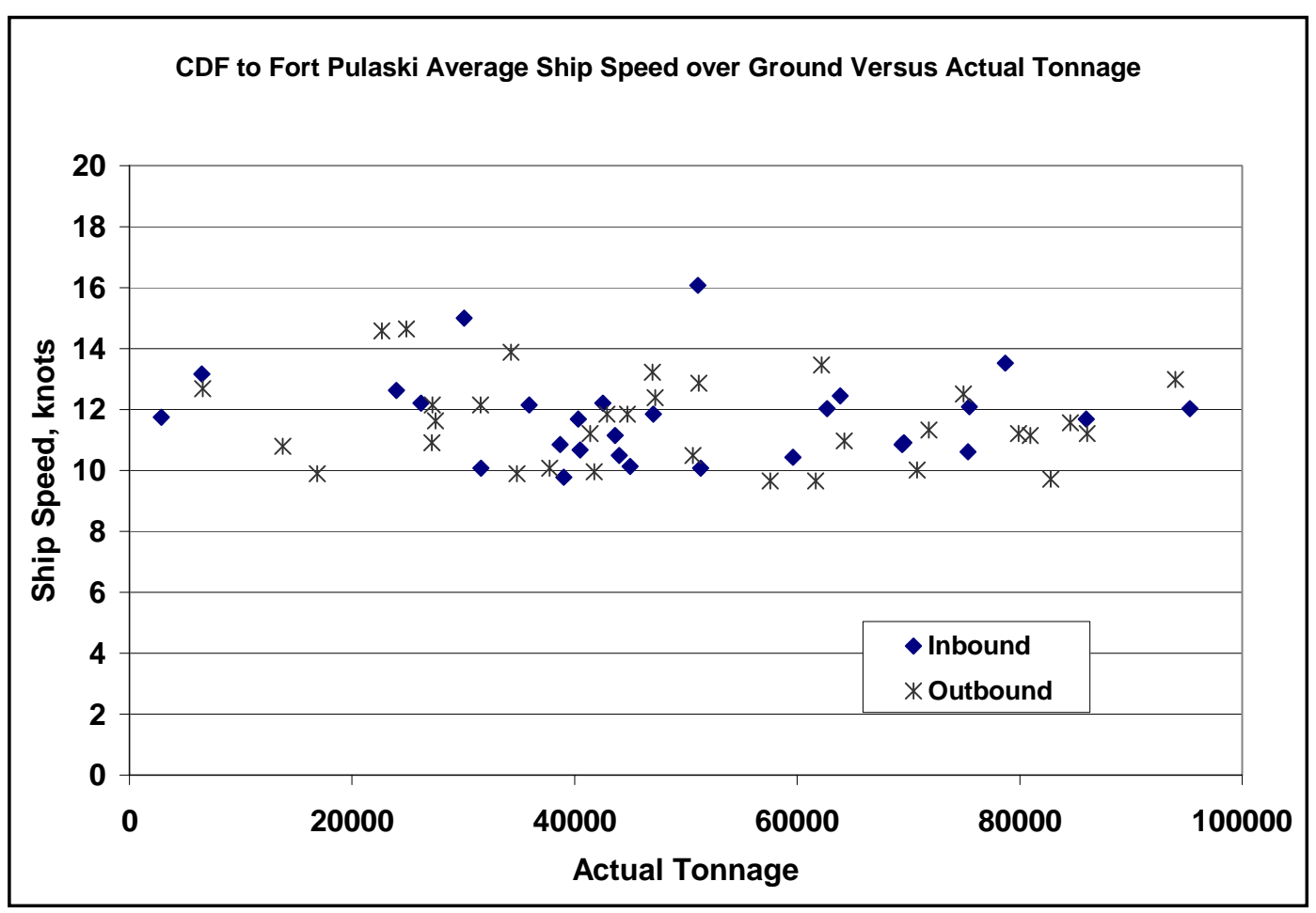

Figure 15. Ship speed versus ship size averaged over CDF to Fort Pulaski reach. 


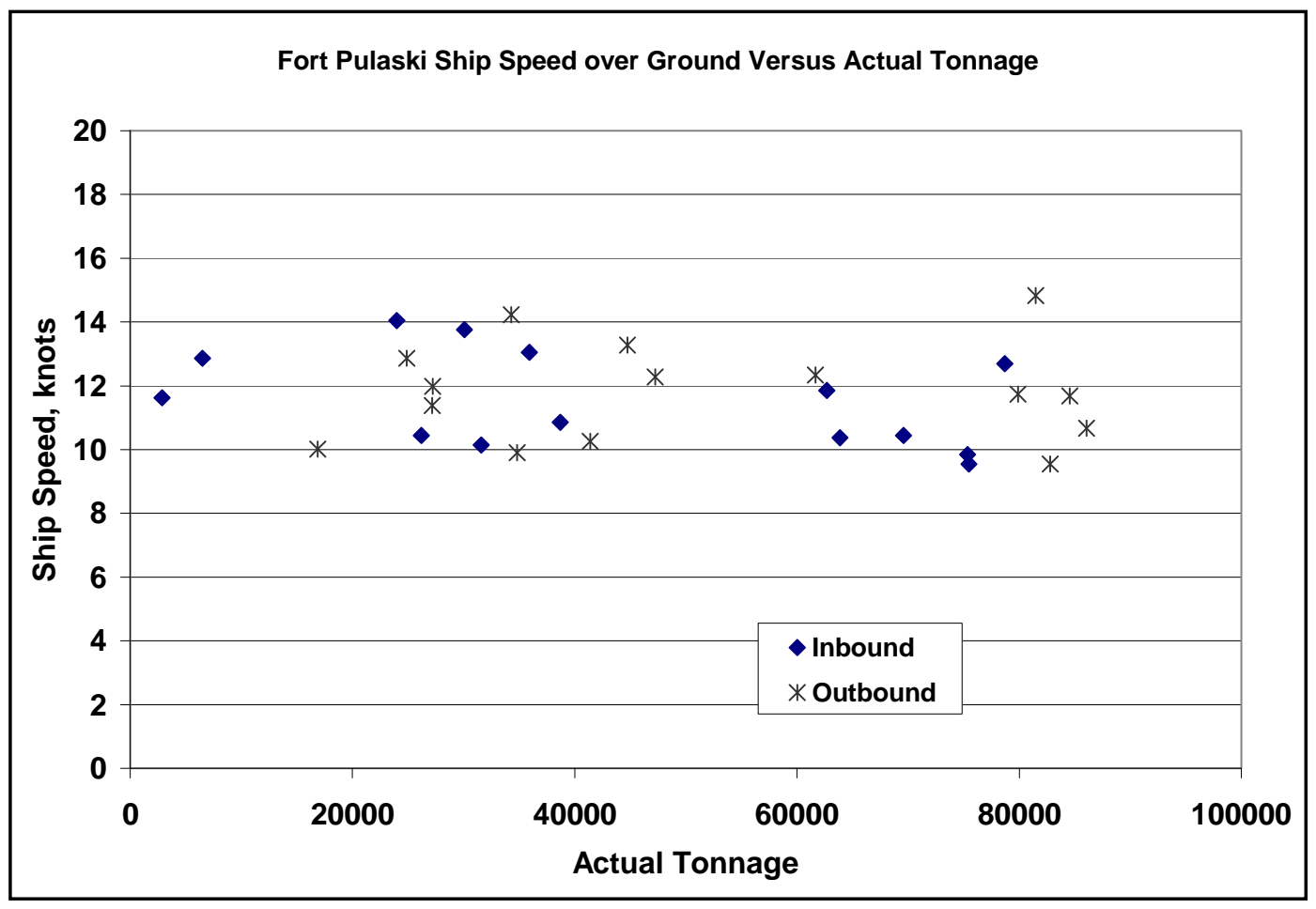

Figure 16. Ship speed versus ship size at Fort Pulaski camera.

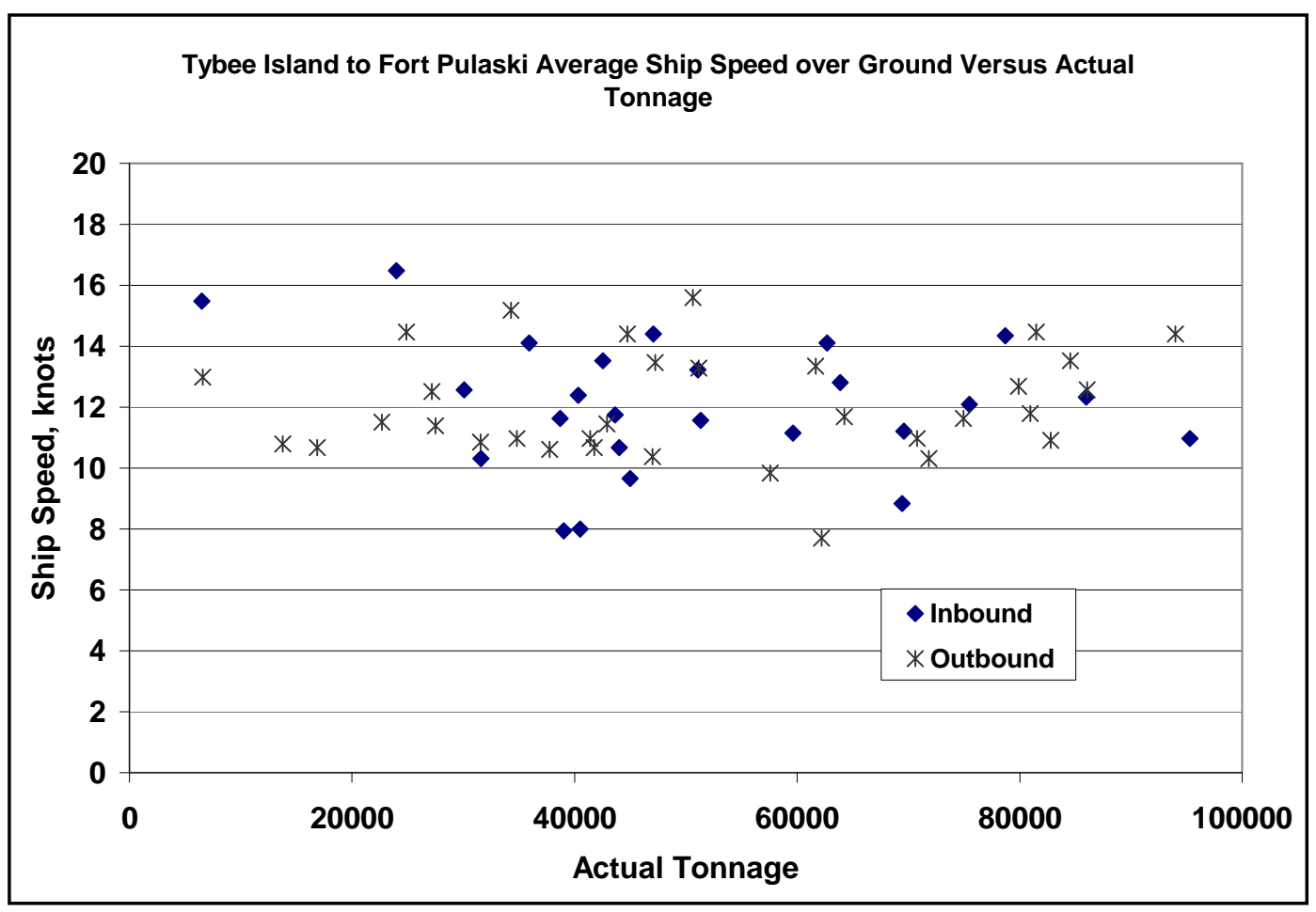

Figure 17. Ship speed versus ship size averaged over reach between Fort Pulaski and TI. 


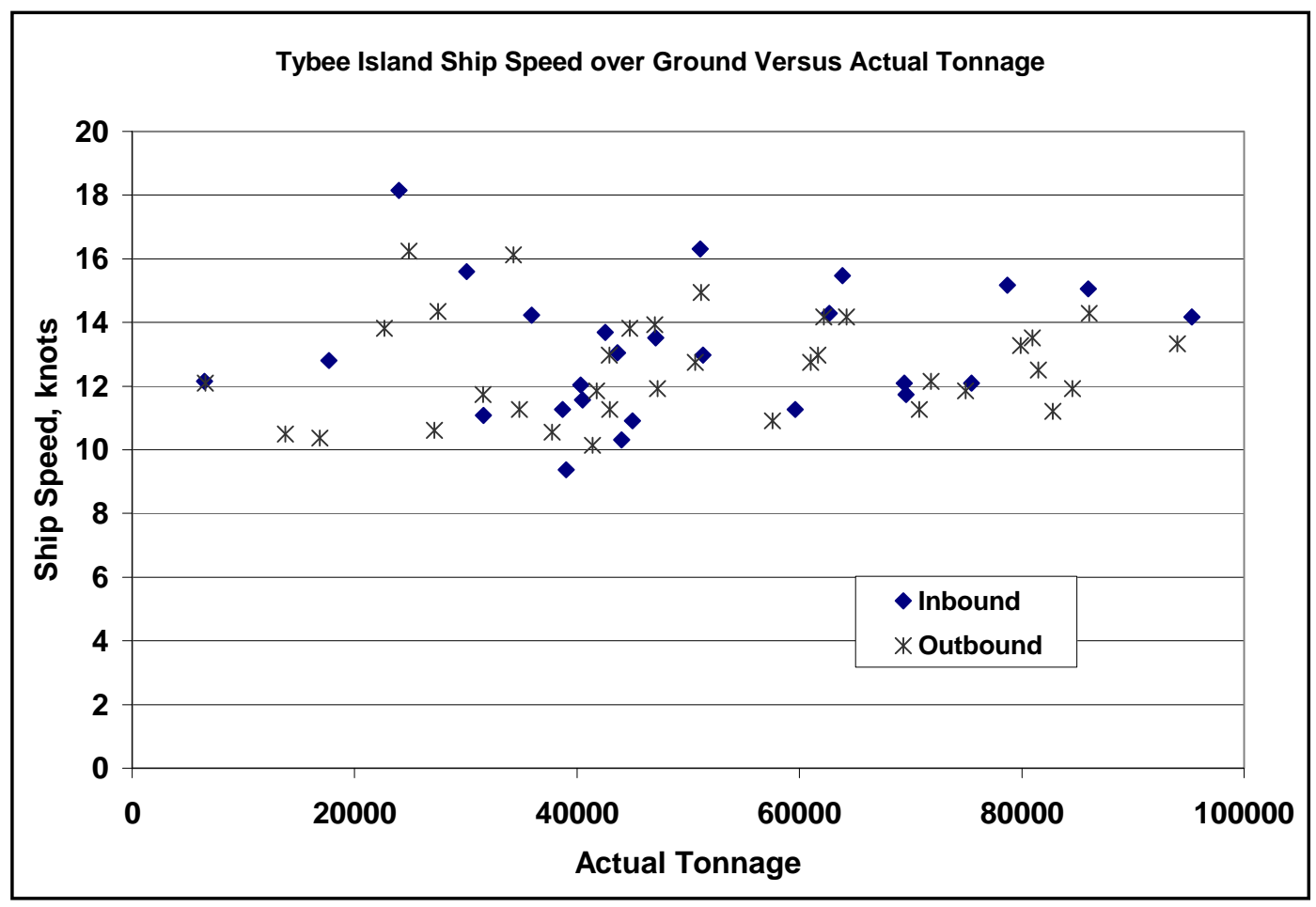

Figure 18. Ship speed versus ship size at Tybee Island.

This paragraph answers the critical question presented in the introduction of how to determine comparable speeds in without-project (existing) and with-project (deepened) channels. This study is based on the premise that it is not valid to simply assume that speeds will be equal in the withoutproject (existing) and the with-project (deepened) channels because channel size affects ship speed. In the analysis of ship effects at FP and TI presented subsequently, ships in the existing channel will traverse the channel at the overall average speed given in Table 8 for both locations. This overall average speed will be used as the typical speed for ships in the without-project channel. While the trend of all ships in the existing channel and existing fleet is no significant change in speed with ship size, the analysis herein focuses on comparing the same ship in existing and deepened channels. For example, consider the Panamax ships that are the most frequent ships in both existing and deepened channels. In both channels, the ship size at design draft conditions is $40.7 \mathrm{ft} \mathrm{draft} \mathrm{X} 951 \mathrm{ft}$ length X $106 \mathrm{ft}$ beam. Based on experience in study of other channels and the pilot interview, the Panamax ship will traverse both existing and deepened channels using maneuver full power. Since the deepened channel is $5 \mathrm{ft}$ deeper and 4 percent greater in area, the Panamax ship will have a slightly higher speed in the deepened channel. To determine the typical ship speed in the deepened channel requires use of the assumption 
that the power setting will remain the same in existing and deepened channels. Note that this assumption is not that maneuver full will always be used for all ships, only that the power level will be the same in both channels. Since applied ship power is the same in both channels, the resisting force of both ships in both channels will be the same. Resisting force is determined using techniques in Maynord (2000) and depends on channel characteristics, return velocity and drawdown, ship size and type, and speed that are all known for the existing channel. The Schijf equation in the NAVigation EFFects (NAVEFF) model (Maynord 1996) was used to determine average return velocity and drawdown. Equating resistance force in existing and deepened channels and knowing ship size and type and channel characteristics in the deepened channel allows determining ship speed in the deepened channel. As will be shown subsequently, ship speed increased only 0.5 to 1.8 percent ( 0.05 to 0.25 knots) in the deepened channel. This small increase in ship speed reflects the fact that the channel area only increased about 4 percent in the deepened channel. The small increase in speed is consistent with the pilot's statement that ship speed in the deepened channel will be about the same. 


\section{Short Period Wave Model}

The short period wave equation used herein was a modification of the equation used by Blaauw et. al (1984) and Knight (1999) for maximum short period waves formed at bow and stern of the ship given as:

$$
H_{\max }=\beta \frac{B}{L_{e}} s^{-1 / 3}\left(\frac{V}{\sqrt{g}}\right)^{2.67}
$$

where

$$
\begin{aligned}
\mathrm{H}_{\max } & =\text { the maximum wave height } \\
\beta & =\text { a coefficient } \\
\mathrm{B} & =\text { the beam of the ship } \\
\mathrm{L}_{\mathrm{e}} & =\text { the entrance length of the ship } \\
\mathrm{S} & =\text { the lateral distance from the ship } \\
\mathrm{V} & =\text { the ship speed through the water } \\
\mathrm{g} & =\text { the gravitational acceleration }
\end{aligned}
$$

Blaauw and Knight used a single coefficient to represent $\beta \mathrm{B} / \mathrm{L}_{\mathrm{e}}$ and specified that single coefficient for particular vessels and vessel sizes. The modification used herein is to keep the coefficients separate with $\mathrm{B} / \mathrm{L}_{e}$ representing ship hull shape effects and $\beta$ representing ship size effects. The ratio $\mathrm{B} / \mathrm{L}_{\mathrm{e}}$ is determined using limited data from:

$$
\frac{B}{L_{e}}=1.11 C_{b}-0.33
$$

Based on the range of $\mathrm{C}_{\mathrm{b}}$ in Table $5, \mathrm{~B} /$ Le only varies from 0.42 to 0.55 . The coefficient $\beta$ was determined using the field study data from the FP and CDF gages. FP and CDF are $800 \mathrm{ft}$ and $600 \mathrm{ft}$ respectively from the center of the channel. The field data have many factors varying which makes the determination of $\beta$ approximate. These factors include (1) wave shoaling at low tides described previously that would increase wave heights by 50 to 75 percent over deepwater wave heights, (2) unknown and variable lateral position of the ship, (3) different ship hull shapes and sizes, (4) upbound and downbound ships, (5) speed uncertainty that is particularly a problem because the wave equations use speed to about the third power, and (6) FP is a reach where the outbound ships are generally 
accelerating and inbound ships are generally decelerating. Only those ships having the best speed data were used in the analysis that generally came from daytime camera speeds. There were 22 inbound ships and 14 outbound ships. For all ships, $\beta$ was determined to be:

$$
\beta=0.0002 \times \text { beam } \times d r a f t
$$

where beam and draft are both in feet.

Because this coefficient in the wave equation requires specific units, it should not be used as a general equation for wave height in navigation channels and is restricted to the Savannah Harbor analysis. The coefficient $\beta$ is limited to a minimum of 0.2 . The values derived from the product of $\mathrm{B} /$ Le and $\beta$ for the Savannah Harbor data range from 0.2 to 0.64 and are similar to the range of values used by Blaauw et al (1984) and Knight (1999). The data are plotted in Figure 19 with observed wave height versus computed wave height. Several of the values on the right side of the plot having low computed wave height were ships that passed at low tide levels that would have likely resulted in shoaling of the wave heights by a factor of ranging up to 1.5 .

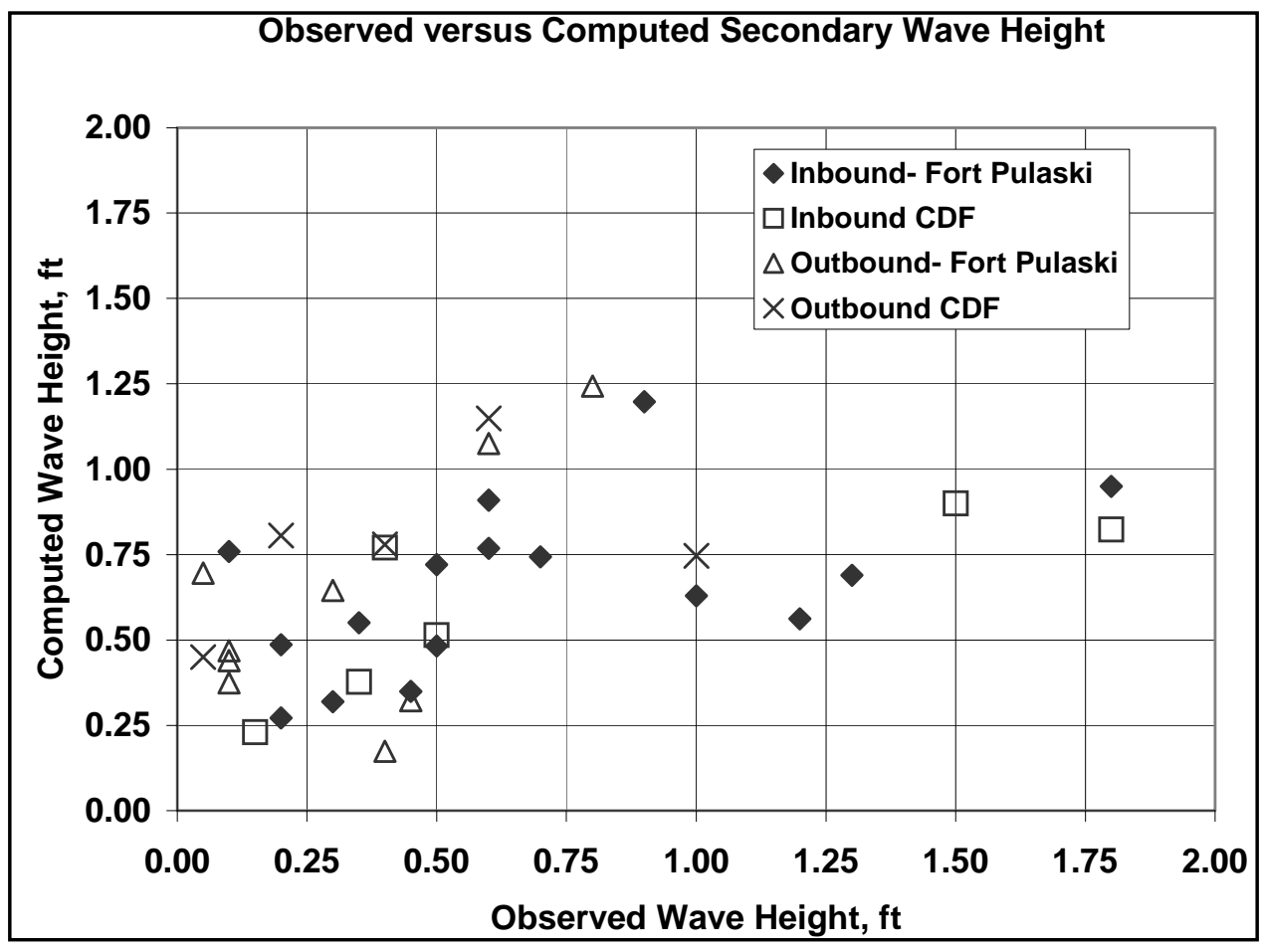

Figure 19. Observed versus computed short period bow and stern wave height using modified Gates and Herbich equation. 
Kamphuis (1987) found correlation of shoreline recession with wave power. Wave power per unit length of shoreline is determined as:

$$
P=\frac{\rho g^{2} H^{2} T}{16 \pi}
$$

where

$$
\begin{aligned}
\mathrm{P} & =\text { wave power } \\
\rho & =\text { water density } \\
\mathrm{H} & =\text { wave height } \\
\mathrm{T} & =\text { wave period }
\end{aligned}
$$

Kamphuis used wave power in the breaking zone. Equation 4 is applicable to wave power for deepwater waves and will be used herein only to compare existing and deepened channels. 


\section{Fort Pulaski Ship Forces Analysis}

The without-project and with-project cross sections at the FP gage are shown in Figure 6. The deepened 48-ft-deep channel cross section assumes advance maintenance of $2 \mathrm{ft}$ at FP. In ship effects studies, channel cross-section area is an important factor and the effective width and crosssection area are determined that eliminate the shallow areas on each side of the channel. The effective channel area was determined to be between bottom contours of $-15 \mathrm{ft}$ MLLW based on the bottom contour giving the lowest displacement effects. In the FP cross section in Figure 6, the channel width at a bottom contour of - $15 \mathrm{ft}$ MLLW is $1,600 \mathrm{ft}$ and effective channel area at a mean tide level of $3.7 \mathrm{ft}$ MLLW is 63,980 sq ft. With the navigation channel deepened to - $50 \mathrm{ft}$ MLLW, the effective channel area is $66,800 \mathrm{sq} \mathrm{ft}$ and effective width remains at 1,600 ft. The increase in effective area is only about 4.4 percent.

The typical speed of the design ships (80 percent of design draft and 100 percent of design draft) in the existing channel are set equal to the observed average speed from the field study of $11.7 \mathrm{knots}$. The design ships are also evaluated at a speed of 2 knots greater than the speed observed in the field study or $13.7 \mathrm{knots}$ for the FP site in the existing channel. The higher speed was used to address a broader range of conditions and to see if conclusions were affected by the ship speed used in the analysis. The 2-knot speed increase at FP was selected because 13.7 knots is near the maximum speed observed in the field study. As will be seen subsequently, the selected ship power or speed did not affect the conclusions.

Ship speed in the deepened channel was based on techniques described in Chapter 5. Ship speeds in the deepened channel are only 0.5 to 1.8 percent greater except for the post-Panamax ships where draft increased from $40.7 \mathrm{ft}$ to $45.3 \mathrm{ft}$ in the deepened channel. For the 45.3 -ft draft postPanamax ship in the deepened channel, ship speed decreased 4-5 percent. The smallest category of ship (Feeder) is not used in Table 9 because the percentage of ships of this type is negligible. In all cases, each ship in the deepened channel had slightly less drawdown and return velocity as shown in Table 9. The conclusion of slightly less drawdown and return velocity in the with-project channel is true for both the typical speed comparison and for the high speed comparison. For example, at typical 
speeds and 80 percent draft, the post-Panamax ship had $1.87 \mathrm{ft}$ of drawdown in the without-project channel and $1.78 \mathrm{ft}$ of drawdown in the with-project channel. In the same manner, at high speeds and 80 percent draft, the post-Panamax ship had $3.64 \mathrm{ft}$ of drawdown in the withoutproject channel and $3.58 \mathrm{ft}$ of drawdown in the with-project channel. The same trends and conclusions result from typical and high speed comparisons although absolute magnitude of return velocity and drawdown differs for the two speeds. Short period bow and stern wave heights are also shown in Table 9. Because ship speed is slightly greater in the deepened channel than in the existing channel, short period bow and stern waves that depend on ship speed to an exponent of 2.67 will be greater in the deepened channel. The conclusion of slightly greater short period bow and stern wave heights in the with-project channel is true for both the typical speed comparison and for the high speed comparison.

Table 9. Ship effects analysis for Fort Pulaski. Return velocity and drawdown are averages over cross section based on Schijf equation in NAVEFF.

\begin{tabular}{|c|c|c|c|c|c|c|}
\hline Draft/channel & Ship & $\begin{array}{l}\text { Typical } \\
\text { ship } \\
\text { speed, } \\
\text { knots }\end{array}$ & $\begin{array}{l}\text { High } \\
\text { ship } \\
\text { speed, } \\
\text { knots }\end{array}$ & $\begin{array}{l}\text { Return } \\
\text { Velocity/ } \\
\text { Drawdown for } \\
\text { typical speed, } \\
\text { ft/sec }\end{array}$ & $\begin{array}{l}\text { Return } \\
\text { Velocity/ } \\
\text { Drawdown, for } \\
\text { high speed, } \\
\text { ft/sec }\end{array}$ & $\begin{array}{l}\text { Short period } \\
\text { bow and stern } \\
\text { wave height for } \\
\text { typical/ high } \\
\text { speed, ft }\end{array}$ \\
\hline \multirow{5}{*}{$\begin{array}{l}\text { Typical (80\%) } \\
\text { draft/existing } \\
(63980)^{*}\end{array}$} & $\begin{array}{l}\text { PP-1044 X } 140 \\
\text { X } 36.2\end{array}$ & 11.7 & 13.7 & $2.85 / 1.87$ & $4.61 / 3.64$ & $1.43 / 2.18$ \\
\hline & $\begin{array}{l}\text { PA-951 X } 106 \\
\text { X } 32.6\end{array}$ & 11.7 & 13.7 & $1.77 / 1.14$ & $2.75 / 2.09$ & $0.98 / 1.49$ \\
\hline & $\begin{array}{l}\text { SP-716 X } 99.8 \\
\times 30.2 \\
\end{array}$ & 11.7 & 13.7 & $1.51 / 0.96$ & $2.30 / 1.73$ & $0.85 / 1.30$ \\
\hline & $\begin{array}{l}\text { HS-579 X } 85.1 \\
\times 25.4\end{array}$ & 11.7 & 13.7 & $1.04 / 0.66$ & $1.53 / 1.14$ & $0.61 / 0.93$ \\
\hline & $\begin{array}{l}\text { FM-428 X } 67.7 \\
\text { X } 20.2\end{array}$ & 11.7 & 13.7 & $0.64 / 0.40$ & $0.92 / 0.67$ & $0.39 / 0.59$ \\
\hline \multirow{5}{*}{$\begin{array}{l}\text { Typical (80\%) } \\
\text { draft/deepened } \\
(66800)\end{array}$} & $\begin{array}{l}\text { PP-1044 X } 140 \\
\text { X } 36.2\end{array}$ & 11.85 & 13.85 & $2.69 / 1.78$ & $4.49 / 3.58$ & $1.48 / 2.25$ \\
\hline & $\begin{array}{l}\text { PA-951 X } 106 \\
\text { X } 32.6\end{array}$ & 11.8 & 13.9 & $1.67 / 1.08$ & $2.59 / 1.99$ & $1.00 / 1.55$ \\
\hline & $\begin{array}{l}\text { SP-716 X } 99.8 \\
\times 30.2\end{array}$ & 11.8 & 13.9 & $1.43 / 0.92$ & $2.17 / 1.66$ & $0.87 / 1.35$ \\
\hline & $\begin{array}{l}\text { HS-579 X } 85.1 \\
\text { X } 25.4\end{array}$ & 11.75 & 13.85 & $0.98 / 0.62$ & $1.45 / 1.08$ & $0.62 / 0.96$ \\
\hline & $\begin{array}{l}\text { FM-428 X } 67.7 \\
\text { X } 20.2\end{array}$ & 11.75 & 13.8 & $0.60 / 0.38$ & $0.86 / 0.63$ & $0.39 / 0.60$ \\
\hline
\end{tabular}




\begin{tabular}{|c|c|c|c|c|c|c|}
\hline Draft/channel & Ship & $\begin{array}{l}\text { Typical } \\
\text { ship } \\
\text { speed, } \\
\text { knots }\end{array}$ & $\begin{array}{l}\text { High } \\
\text { ship } \\
\text { speed, } \\
\text { knots }\end{array}$ & $\begin{array}{l}\text { Return } \\
\text { Velocity/ } \\
\text { Drawdown for } \\
\text { typical speed, } \\
\text { ft/sec }\end{array}$ & $\begin{array}{l}\text { Return } \\
\text { Velocity/ } \\
\text { Drawdown, for } \\
\text { high speed, } \\
\text { ft/sec }\end{array}$ & $\begin{array}{l}\text { Short period } \\
\text { bow and stern } \\
\text { wave height for } \\
\text { typical/ high } \\
\text { speed, ft }\end{array}$ \\
\hline \multirow[t]{5}{*}{$\begin{array}{l}\text { Design draft/ } \\
\text { existing (63980) }\end{array}$} & $\begin{array}{l}\text { PP-1044 X } \\
140 \times 40.7 * *\end{array}$ & 11.7 & 13.7 & $3.33 / 2.22$ & $5.08 / 4.05$ & $1.61 / 2.45$ \\
\hline & $\begin{array}{l}\text { PA-951 X } 106 \\
\text { X } 40.7\end{array}$ & 11.7 & 13.7 & $2.32 / 1.51$ & $3.81 / 2.96$ & $1.22 / 1.86$ \\
\hline & $\begin{array}{l}\text { SP-716 X } 99.8 \\
\times 37.7\end{array}$ & 11.7 & 13.7 & $1.96 / 1.26$ & $3.10 / 2.37$ & $1.06 / 1.62$ \\
\hline & $\begin{array}{l}\text { HS-579 X } 85.1 \\
\text { X } 31.8\end{array}$ & 11.7 & 13.7 & $1.34 / 0.85$ & $2.01 / 1.51$ & $0.76 / 1.16$ \\
\hline & $\begin{array}{l}\text { FM-428 X } 67.7 \\
\text { X } 25.2\end{array}$ & & & $0.81 / 0.51$ & $1.17 / 0.86$ & $0.48 / 0.73$ \\
\hline \multirow{5}{*}{$\begin{array}{l}\text { Design draft/ } \\
\text { deepened } \\
\text { (66800) }\end{array}$} & $\begin{array}{l}\text { PP-1044 X } 140 \\
\text { X } 45.3\end{array}$ & 11.25 & 13.00 & $3.19 / 2.04$ & $5.02 / 3.82$ & $1.61 / 2.37$ \\
\hline & $\begin{array}{l}\text { PA-951 X } 106 \\
\text { X } 40.7\end{array}$ & 11.85 & 13.95 & $2.20 / 1.44$ & $3.58 / 2.82$ & $1.26 / 1.95$ \\
\hline & $\begin{array}{l}\text { SP-716 X } 99.8 \\
\text { X } 37.7\end{array}$ & 11.85 & 13.95 & $\mid 1.87 / 1.21$ & $2.94 / 2.28$ & \begin{tabular}{|l|}
$1.10 / 1.70$ \\
\end{tabular} \\
\hline & $\begin{array}{l}\text { HS-579 X } 85.1 \\
\text { X } 31.8\end{array}$ & 11.8 & 13.9 & $1.27 / 0.81$ & $1.90 / 1.44$ & $0.78 / 1.21$ \\
\hline & $\begin{array}{l}\text { FM-428 X } 67.7 \\
\text { X } 25.2\end{array}$ & 11.75 & 13.85 & $0.76 / 0.48$ & $1.11 / 0.82$ & $0.49 / 0.76$ \\
\hline
\end{tabular}

Using the frequency of calls in Table 6 to incorporate the different fleet characteristics, a composite return velocity, drawdown, and short period bow and stern wave height can be developed for comparing the withoutproject and with-project channels. For example, composite drawdown in the existing channel with the 80-percent draft and 2030 GEC traffic estimate and typical ship speed $=($ percent of $\mathrm{PP}) \times(\mathrm{PP}$ drawdown $)+$ (percent of PA $) \times($ PA drawdown $)+($ percent of SP $) \times($ SP drawdown $)+$ $($ percent of HS $) \times($ HS drawdown $)+($ percent of FM $) \times($ FM drawdown $)=$ $0.052 \times 1.87+0.827 \times 1.14+0.063 \times 0.96+0.053 \times 0.66+0.004 \times 0.40$ $=1.14 \mathrm{ft}$. Tables 10-13 show all the composite parameters for FP for the four traffic scenarios. Conclusions and trends are the same for 2030 and 2050 and for the four traffic scenarios. For example, composite drawdown for typical speed, typical (80 percent) draft in the existing channel for 2030 GEC traffic is $1.14 \mathrm{ft}$ versus composite drawdown for typical speed, typical (80 percent) draft in the deepened channel for 2030 traffic of $1.08 \mathrm{ft}$. Composite drawdown for high speed, typical (80 percent) draft in 
the existing channel for 2030 traffic is $2.09 \mathrm{ft}$ versus composite drawdown for high speed, typical (80 percent) draft in the deepened channel for 2030 GEC traffic of $2.00 \mathrm{ft}$. The comparison of without-project to with-project composite values shows the same trends and conclusions for both typical speed and higher ship speed. Considering all values in Tables 10-13, composite return velocity and drawdown at FP are about 3.2 to 6.2 percent less in the with-project channel.

Table 10. Composite return velocity $\left(\mathrm{V}_{\mathrm{r}}\right)$, drawdown, and short period bow and stern wave height for Fort Pulaski based on Table 9 and ship frequency in Table 6 for GEC scenario.

Values in () show percent change from without-project to with-project.

\begin{tabular}{|c|c|c|c|c|c|c|}
\hline \multirow{2}{*}{$\begin{array}{l}\text { Draft/channel/ } \\
\text { traffic year }\end{array}$} & \multicolumn{3}{|c|}{ Composite for Typical Speed } & \multicolumn{3}{|c|}{ Composite for High Speed } \\
\hline & $V_{r}, \mathrm{ft} / \mathrm{sec}$ & Drawdown, ft & Wave height, $\mathrm{ft}$ & $V_{r}, \mathrm{ft} / \mathrm{sec}$ & Drawdown, $\mathrm{ft}$ & Wave height, $\mathrm{ft}$ \\
\hline $\begin{array}{l}\text { Typical Draft/ } \\
\text { existing/2030 }\end{array}$ & 1.77 & 1.14 & 0.97 & 2.75 & 2.09 & 1.48 \\
\hline $\begin{array}{l}\text { Typical Draft/ } \\
\text { deepened/2030 }\end{array}$ & $\begin{array}{l}1.67 \\
(-5.6 \%)\end{array}$ & $\begin{array}{l}1.08 \\
(-5.3 \%)\end{array}$ & $\begin{array}{l}0.99 \\
(+2.1 \%)\end{array}$ & $\begin{array}{l}2.59 \\
(-5.8 \%)\end{array}$ & $\begin{array}{l}2.00 \\
(-4.3 \%)\end{array}$ & $\begin{array}{l}1.54 \\
(+4.1 \%)\end{array}$ \\
\hline $\begin{array}{l}\text { Design Draft/ } \\
\text { existing/2030 }\end{array}$ & 2.29 & 1.49 & 1.20 & 3.72 & 2.89 & 1.83 \\
\hline $\begin{array}{l}\text { Design Draft/ } \\
\text { deepened/2030 }\end{array}$ & $\begin{array}{l}2.17 \\
(-5.2 \%)\end{array}$ & $\begin{array}{l}1.42 \\
(-4.7 \%)\end{array}$ & $\begin{array}{l}1.24 \\
(+3.3 \%)\end{array}$ & $\begin{array}{l}3.51 \\
(-5.6 \%)\end{array}$ & $\begin{array}{l}2.76 \\
(-4.5 \%)\end{array}$ & $\begin{array}{l}1.91 \\
(+4.4 \%)\end{array}$ \\
\hline $\begin{array}{l}\text { Typical Draft/ } \\
\text { existing/2050 }\end{array}$ & 1.76 & 1.14 & 0.97 & 2.74 & 2.08 & 1.48 \\
\hline $\begin{array}{l}\text { Typical Draft/ } \\
\text { deepened/2050 }\end{array}$ & $\begin{array}{l}1.66 \\
(-5.7 \%)\end{array}$ & $\begin{array}{l}1.08 \\
(-5.3 \%)\end{array}$ & $\begin{array}{l}0.99 \\
(+2.1 \%)\end{array}$ & $\begin{array}{l}2.59 \\
(-5.5 \%)\end{array}$ & $\begin{array}{l}1.99 \\
(-4.3 \%)\end{array}$ & $\begin{array}{l}1.54 \\
(+4.1 \%)\end{array}$ \\
\hline $\begin{array}{l}\text { Design Draft/ } \\
\text { existing/2050 }\end{array}$ & 2.29 & 1.49 & 1.20 & 3.74 & 2.90 & 1.84 \\
\hline $\begin{array}{l}\text { Design Draft/ } \\
\text { deepened/2050 }\end{array}$ & $\begin{array}{l}2.18 \\
(-4.8 \%)\end{array}$ & $\begin{array}{l}1.42 \\
(-4.7 \%)\end{array}$ & $\begin{array}{l}1.24 \\
(+3.3 \%)\end{array}$ & $\begin{array}{l}3.52 \\
(-5.9 \%)\end{array}$ & $\begin{array}{l}2.76 \\
(-4.8 \%)\end{array}$ & $\begin{array}{l}1.92 \\
(+4.3 \%)\end{array}$ \\
\hline
\end{tabular}


Table 11. Composite return velocity, drawdown, and short period bow and stern wave height for Fort Pulaski based on Table 9 and ship frequency in Table 6 for 10 percent scenario. Values in () show percent change from without-project to with-project.

\begin{tabular}{|c|c|c|c|c|c|c|}
\hline \multirow[b]{2}{*}{ Draft/channel/ traffic year } & \multicolumn{3}{|c|}{ Composite for Typical Speed } & \multicolumn{3}{|c|}{ Composite for High Speed } \\
\hline & \begin{tabular}{|l|}
$\mathrm{Vr}$ \\
$\mathrm{ft} / \mathrm{sec}$
\end{tabular} & $\begin{array}{l}\text { Drawdown, } \\
\mathrm{ft}\end{array}$ & $\begin{array}{l}\text { Wave height, } \\
\mathrm{ft}\end{array}$ & $\begin{array}{l}\mathrm{Vr} \\
\mathrm{ft} / \mathrm{sec}\end{array}$ & $\begin{array}{l}\text { Drawdown, } \\
\mathrm{ft}\end{array}$ & $\begin{array}{l}\text { Wave height, } \\
\mathrm{ft}\end{array}$ \\
\hline Typical Draft/ existing/2030 & 1.86 & 1.20 & 1.01 & 2.91 & 2.23 & 1.54 \\
\hline $\begin{array}{l}\text { Typical Draft/ } \\
\text { deepened/2030 }\end{array}$ & \begin{tabular}{|l|}
1.76 \\
$(-5.4 \%)$
\end{tabular} & \begin{tabular}{|l|}
1.14 \\
$(-5.0 \%)$
\end{tabular} & \begin{tabular}{|l}
1.04 \\
$(+3.0 \%)$
\end{tabular} & \begin{tabular}{|l|}
2.76 \\
$(-5.2 \%)$
\end{tabular} & \begin{tabular}{|l|}
2.14 \\
$(-4.0 \%)$
\end{tabular} & $\begin{array}{l}1.60 \\
(+3.9 \%)\end{array}$ \\
\hline Design Draft/ existing/2030 & 2.38 & 1.55 & 1.24 & 3.83 & 2.99 & 1.88 \\
\hline $\begin{array}{l}\text { Design Draft/ } \\
\text { deepened/2030 }\end{array}$ & \begin{tabular}{|l|}
2.26 \\
$(-5.0 \%)$
\end{tabular} & \begin{tabular}{|l|}
1.47 \\
$(-5.2 \%)$
\end{tabular} & $\begin{array}{l}1.27 \\
(+2.4 \%)\end{array}$ & \begin{tabular}{|l|}
3.64 \\
$(-5.0 \%)$
\end{tabular} & \begin{tabular}{|l|}
2.84 \\
$(-5.0 \%)$
\end{tabular} & $\begin{array}{l}1.95 \\
(+3.8 \%)\end{array}$ \\
\hline Typical Draft/ existing/2050 & 1.86 & 1.20 & 1.01 & 2.91 & 2.22 & 1.54 \\
\hline $\begin{array}{l}\text { Typical Draft/ } \\
\text { deepened/2050 }\end{array}$ & $\begin{array}{l}1.76 \\
(-5.4 \%)\end{array}$ & $\begin{array}{l}1.14 \\
(-5.0 \%)\end{array}$ & $\begin{array}{l}1.04 \\
(+3.0 \%)\end{array}$ & $\begin{array}{l}2.76 \\
(-5.2 \%)\end{array}$ & $\begin{array}{l}2.13 \\
(-4.1 \%)\end{array}$ & $\begin{array}{l}1.60 \\
(+3.9 \%)\end{array}$ \\
\hline Design Draft/ existing/2050 & 2.38 & 1.56 & 1.24 & 3.85 & 3.00 & 1.89 \\
\hline $\begin{array}{l}\text { Design Draft/ } \\
\text { deepened/2050 }\end{array}$ & $\begin{array}{l}2.27 \\
(-4.6 \%)\end{array}$ & \begin{tabular}{|l|}
1.47 \\
$(-5.8 \%)$
\end{tabular} & $\begin{array}{l}1.27 \\
(+2.4 \%)\end{array}$ & \begin{tabular}{|l|}
3.65 \\
$(-5.2 \%)$
\end{tabular} & $\begin{array}{l}2.85 \\
(-5.0 \%)\end{array}$ & $\begin{array}{l}1.96 \\
(+3.7 \%)\end{array}$ \\
\hline
\end{tabular}

Table 12. Composite return velocity, drawdown, and short period bow and stern wave height for Fort Pulaski based on Table 9 and ship frequency in Table 6 for 20 percent scenario. Values in () show percent change from without-project to with-project.

\begin{tabular}{|c|c|c|c|c|c|c|}
\hline \multirow[b]{2}{*}{ Draft/channel/ traffic year } & \multicolumn{3}{|c|}{ Composite for Typical Speed } & \multicolumn{3}{|c|}{ Composite for High Speed } \\
\hline & \begin{tabular}{|l|}
$\mathrm{Vr}$, \\
$\mathrm{ft} / \mathrm{sec}$
\end{tabular} & $\begin{array}{l}\text { Drawdown, } \\
\mathrm{ft}\end{array}$ & $\begin{array}{l}\text { Wave height, } \\
\mathrm{ft}\end{array}$ & $\begin{array}{l}\mathrm{Vr}, \\
\mathrm{ft} / \mathrm{sec}\end{array}$ & $\begin{array}{l}\text { Drawdown, } \\
\mathrm{ft}\end{array}$ & $\begin{array}{l}\text { Wave height, } \\
\mathrm{ft}\end{array}$ \\
\hline Typical Draft/ existing/2030 & 1.96 & 1.27 & 1.05 & 3.07 & 2.36 & 1.60 \\
\hline $\begin{array}{l}\text { Typical Draft/ } \\
\text { deepened/2030 }\end{array}$ & \begin{tabular}{|l|}
1.85 \\
$(-5.6 \%)$
\end{tabular} & \begin{tabular}{|l|}
1.20 \\
$(-5.5 \%)$
\end{tabular} & $\begin{array}{l}1.08 \\
(+2.9 \%)\end{array}$ & \begin{tabular}{|l|}
2.93 \\
$(-4.6 \%)$
\end{tabular} & \begin{tabular}{|l|}
2.28 \\
$(-3.4 \%)$
\end{tabular} & $\begin{array}{l}1.66 \\
(+3.8 \%)\end{array}$ \\
\hline Design Draft/ existing/2030 & 2.47 & 1.62 & 1.27 & 3.95 & 3.08 & 1.94 \\
\hline $\begin{array}{l}\text { Design Draft/ } \\
\text { deepened/2030 }\end{array}$ & \begin{tabular}{|l|}
2.35 \\
$(-4.9 \%)$
\end{tabular} & \begin{tabular}{|l|}
1.52 \\
$(-6.2 \%)$
\end{tabular} & $\begin{array}{l}1.30 \\
(+2.4 \%)\end{array}$ & \begin{tabular}{|l|}
3.77 \\
$(-4.6 \%)$
\end{tabular} & \begin{tabular}{|l|}
2.93 \\
$(-4.9 \%)$
\end{tabular} & $\begin{array}{l}1.98 \\
(+2.1 \%)\end{array}$ \\
\hline Typical Draft/ existing/2050 & 1.96 & 1.27 & 1.05 & 3.07 & 2.36 & 1.60 \\
\hline $\begin{array}{l}\text { Typical Draft/ } \\
\text { deepened/2050 }\end{array}$ & $\begin{array}{l}1.85 \\
(-5.6 \%)\end{array}$ & $\begin{array}{l}1.20 \\
(-5.5 \%)\end{array}$ & $\begin{array}{l}1.08 \\
(+2.9 \%)\end{array}$ & $\begin{array}{l}2.93 \\
(-4.6 \%)\end{array}$ & $\begin{array}{l}2.28 \\
(-3.4 \%)\end{array}$ & \begin{tabular}{|l}
1.66 \\
$(+3.8 \%)$
\end{tabular} \\
\hline Design Draft/ existing/2050 & 2.47 & 1.62 & 1.27 & 3.96 & 3.10 & 1.94 \\
\hline $\begin{array}{l}\text { Design Draft/ } \\
\text { deepened/2050 }\end{array}$ & $\begin{array}{l}2.35 \\
(-4.9 \%)\end{array}$ & $\begin{array}{l}1.53 \\
(-5.6 \%)\end{array}$ & $\begin{array}{l}1.31 \\
(+3.1 \%)\end{array}$ & $\begin{array}{l}3.78 \\
(-4.5 \%)\end{array}$ & $\begin{array}{l}2.94 \\
(-5.2 \%)\end{array}$ & $\begin{array}{l}1.99 \\
(+2.6 \%)\end{array}$ \\
\hline
\end{tabular}


Table 13. Composite return velocity, drawdown, and short period bow and stern wave height for Fort Pulaski based on Table 9 and ship frequency in Table 6 for 30 percent scenario. Values in () show percent change from without-project to with-project.

\begin{tabular}{|c|c|c|c|c|c|c|}
\hline \multirow[b]{2}{*}{ Draft/channel/ traffic year } & \multicolumn{3}{|c|}{ Composite for Typical Speed } & \multicolumn{3}{|c|}{ Composite for High Speed } \\
\hline & \begin{tabular}{|l|}
$\mathrm{Vr}$ \\
$\mathrm{ft} / \mathrm{sec}$
\end{tabular} & $\begin{array}{l}\text { Drawdown, } \\
\mathrm{ft}\end{array}$ & $\begin{array}{l}\text { Wave height, } \\
\mathrm{ft}\end{array}$ & $\begin{array}{l}\mathrm{Vr} \\
\mathrm{ft} / \mathrm{sec}\end{array}$ & $\begin{array}{l}\text { Drawdown, } \\
\mathrm{ft}\end{array}$ & $\begin{array}{l}\text { Wave height, } \\
\mathrm{ft}\end{array}$ \\
\hline Typical Draft/ existing/2030 & 2.05 & 1.33 & 1.09 & 3.24 & 2.50 & 1.66 \\
\hline $\begin{array}{l}\text { Typical Draft/ } \\
\text { deepened/2030 }\end{array}$ & \begin{tabular}{|l|}
1.94 \\
$(-5.4 \%)$
\end{tabular} & \begin{tabular}{|l|}
1.26 \\
$(-5.3 \%)$
\end{tabular} & $\begin{array}{l}1.12 \\
(+2.8 \%)\end{array}$ & \begin{tabular}{|l|}
3.10 \\
$(-4.3 \%)$
\end{tabular} & \begin{tabular}{|l|}
2.42 \\
$(-3.2 \%)$
\end{tabular} & $\begin{array}{l}1.72 \\
(+3.6 \%)\end{array}$ \\
\hline Design Draft/ existing/2030 & 2.56 & 1.68 & 1.31 & 4.06 & 3.18 & 1.99 \\
\hline $\begin{array}{l}\text { Design Draft/ } \\
\text { deepened/2030 }\end{array}$ & \begin{tabular}{|l|}
2.44 \\
$(-4.7 \%)$
\end{tabular} & \begin{tabular}{|l|}
1.58 \\
$(-6.0 \%)$
\end{tabular} & \begin{tabular}{|l}
1.33 \\
$(+1.5 \%)$
\end{tabular} & \begin{tabular}{|l|}
3.89 \\
$(-4.2 \%)$
\end{tabular} & \begin{tabular}{|l|}
3.02 \\
$(-5.0 \%)$
\end{tabular} & $\begin{array}{l}2.02 \\
(+1.5 \%)\end{array}$ \\
\hline Typical Draft/ existing/2050 & 2.05 & 1.33 & 1.09 & 3.24 & 2.50 & 1.67 \\
\hline $\begin{array}{l}\text { Typical Draft/ } \\
\text { deepened/2050 }\end{array}$ & $\begin{array}{l}1.94 \\
(-5.4 \%)\end{array}$ & $\begin{array}{l}1.27 \\
(-4.5 \%)\end{array}$ & $\begin{array}{l}1.12 \\
(+2.8 \%)\end{array}$ & $\begin{array}{l}3.10 \\
(-4.3 \%)\end{array}$ & $\begin{array}{l}2.42 \\
(-3.2 \%)\end{array}$ & $\begin{array}{l}1.73 \\
(+3.6 \%)\end{array}$ \\
\hline Design Draft/ existing/2050 & 2.57 & 1.68 & 1.31 & 4.08 & 3.20 & 2.00 \\
\hline $\begin{array}{l}\text { Design Draft/ } \\
\text { deepened/2050 }\end{array}$ & $\begin{array}{l}2.44 \\
(-5.1 \%)\end{array}$ & $\begin{array}{l}1.58 \\
(-6.0 \%)\end{array}$ & $\begin{array}{l}1.34 \\
(+2.3 \%)\end{array}$ & \begin{tabular}{|l|}
3.91 \\
$(-4.2 \%)$
\end{tabular} & \begin{tabular}{|l|}
3.03 \\
$(-5.3 \%)$
\end{tabular} & $\begin{array}{l}2.03 \\
(+1.5 \%)\end{array}$ \\
\hline
\end{tabular}

Composite short period bow and stern wave heights at FP in Tables 10-13 show no significant difference between 2030 and 2050 but show small changes in the with-project channel between traffic scenarios. All composite wave heights in Tables 10-13 range from 1.5 to 4.4 percent greater in the deepened channel.

Wave power, found by Kamphuis (1987) to correlate with shoreline recession, was calculated with Equation 4 . Bow and stern wave periods from the field study were 3-3.5 sec. The composite short period wave height increases of 1.5 to 4.4 percent result in wave power increases of 2.3 to 19 percent. 


\section{Tybee Island Ship Forces Analysis}

One unusual characteristic of the ship effects evaluation at TI is the presence of the partially submerged jetty on the south side of the ship channel and a less partially submerged jetty on the north side of the channel. The south jetty is about 3,400 ft north of the TI gages and has a variable top elevation that averages about $4 \mathrm{ft}$ above MLLW. The north jetty has an average top elevation of about $7 \mathrm{ft} \mathrm{MLLW.} \mathrm{The} \mathrm{jetties} \mathrm{are}$ about 2,400 $\mathrm{ft}$ apart. The presence of these jetties makes it important to analyze differences between ships at low and high tides as well as inbound versus outbound. As stated previously, ship effects at the shoreline of navigation channels are generally short period bow and stern waves and long period drawdown or pressure wave effects. Short period bow and stern waves will likely decay in amplitude before reaching the TI shoreline that is about 4,500 ft from the center of the ship channel. Bow and stern wave height generally decays with (distance) $)^{-1 / 3}$ (Sorensen 1966). At $4,500 \mathrm{ft}$ from the ship, the secondary wave will be about 10 percent of the wave height at the ship. Any significant ship effects reaching the TI shoreline will likely be the result of the long period drawdown or pressure wave that can travel significant distances. At low tides, the jetty blocks south movement of ship effects while the ship is within the jetties. Even at high tides, the south jetty provides a significant barrier to long period ship effects. Any ship effects reaching the shoreline at the TI gages at low tides must come from outside of the east end of the jetties along a line that is about 5,500 ft from TI gages to the center of the ship channel.

The ships were separated into those passing with tides of $4 \mathrm{ft}$ MLLW or fewer and those with $7 \mathrm{ft}$ MLLW or greater. Ship passages during the intermediate range of 4 to $7 \mathrm{ft}$ MLLW were excluded because small depths over the jetty may or may not pass significant ship effects over the top of the jetty. The ships were also separated into inbound and outbound resulting in four different groups. Within each of the four groups, the ship effects' patterns and magnitudes exhibit significant differences due to differences in draft, speed, tide direction and magnitude, ship type, and ship lateral position. Table 14 shows each ship in the four categories along with the drawdown at the TI wave gage. Each of the four categories have a ship or ships that produce drawdown of $1 \mathrm{ft}$ or greater. There appears to be no strong correlation of drawdown with either stage or direction of travel. 
It is not possible to conclusively determine whether significant ship drawdown passes over the south jetty at high tides. The main correlation in the data is that large, fast ships cause the most impact. There are several ships that defy the trend of bigger-faster. Under inbound high stage ships, the MSC Eleni and Stuttgart Express are large, fast ships that created little impact. The only ship in the inbound high stage category that causes any significant impact is the J ens Maersk that is somewhat compromised because it met the Talisman at TI. There is no obvious explanation for the lack of impact unless the ships were going slowly before entering the jetties and quickly by the time they reached the location where the TI camera monitored their speed. Several outbound high stage ships caused 6-8 sec period waves that had a height of about $1 \mathrm{ft}$. These included the Hanjin Wilmington and Mol Velocity.

Table 14. Tybee Island ship drawdown.

\begin{tabular}{|c|c|c|c|c|}
\hline Category & Ship name & $\begin{array}{l}\text { Gross Tonnage, speed, } \\
\text { knots over ground }\end{array}$ & $\begin{array}{l}\text { Maximum } \\
\text { Drawdown, ft }\end{array}$ & $\begin{array}{l}\text { Tide, } \mathrm{ft} \text { MLLW } \\
\text { and direction }\end{array}$ \\
\hline \multirow{14}{*}{$\begin{array}{l}\text { Inbound/Stage } \\
<4 \mathrm{ft} \text { MLLW }\end{array}$} & Sun Right & $53359,15.1$ & 1.1 & 1.5, flood \\
\hline & Zim Israel & $37204,10.9$ & 0.2 & -0.1 , bottom \\
\hline & MSC Christina & $37579,13.0$ & 0.75 & -0.2, bottom \\
\hline & Mol Elbe & $50352,12.1$ & 0.85 & -0.2, bottom \\
\hline & Midnight Sun & $27915,10.3$ & 0.2 & -0.4, bottom \\
\hline & Darya Rani & $26054,12.0$ & 0.2 & 0.2 , weak flood \\
\hline & Zim Iberia & $41507,11.3$ & 0.9 & -0.3, bottom \\
\hline & Hanjin Wilmington & $51754,11.7$ & 0.25 & -0.1 , bottom \\
\hline & Condor & $14241,18.1$ & 0.3 & 3.0, flood \\
\hline & Essen Express & $53815,12.1$ & 0.9 & -0.1 , bottom \\
\hline & Angel Accord & $20212,11.1$ & 0.2 & -0.2, bottom \\
\hline & Mol Velocity & $53519,15.5$ & 0.8 & 0.7, flood \\
\hline & Jervis Bay & $50350,14.3$ & 0.2 & 4.4, flood \\
\hline & Borc & $20139,11.3$ & 0.1 & 3.6, flood \\
\hline \multirow{5}{*}{$\begin{array}{l}\text { Inbound/Stage } \\
>7 \mathrm{ft} \text { MLLW }\end{array}$} & MSC Elini & $54841,14.2$ & 0.2 & 8.2, weak ebb \\
\hline & MSC Elena & $30971,13.5$ & 0.1 & 6.3, ebb \\
\hline & Kavo Alexandros II & $16608,14.2$ & 0.1 & 7.8,ebb \\
\hline & Jens Maersk & $30166,14.2$ & 1.4 & 8.4 , flood \\
\hline & Stuttgart Express & $53815,15.2$ & 0.25 & 8.4, weak ebb \\
\hline \multirow{5}{*}{$\begin{array}{l}\text { Outbound/Stage } \\
<4 \mathrm{ft} \text { MLLW }\end{array}$} & Khannur & $96235,11.1$ & 0.5 & -0.4, bottom \\
\hline & New York Express & $54437,11.3$ & 1.3 & 2.0, flood \\
\hline & Star Florida & $23345,11.7$ & 0.8 & 2.5, flood \\
\hline & Jens Maersk & $30166,12.7$ & 1.65 & 3.4, flood \\
\hline & CMA CGM Potomac & $31154,14.9$ & 0.45 & 1.6, ebb \\
\hline
\end{tabular}




\begin{tabular}{|c|c|c|c|c|}
\hline Category & Ship name & $\begin{array}{l}\text { Gross Tonnage, speed, } \\
\text { knots over ground }\end{array}$ & \begin{tabular}{|l} 
Maximum \\
Drawdown, $\mathrm{ft}$
\end{tabular} & $\begin{array}{l}\text { Tide, } \mathrm{ft} \text { MLLW } \\
\text { and direction }\end{array}$ \\
\hline & Kochnev & $6030,10.5$ & 0.2 & 0.9, flood \\
\hline & MSC Eleni & $54881,13.3$ & 0.5 & 0.8, ebb \\
\hline & Midnight Sun & $27915,13.0$ & 0.2 & $0.1 \mathrm{ebb}$ \\
\hline & MSC Elena & $30971,11.9$ & 0.5 & -0.4 , bottom \\
\hline & Condor & $14241,16.2$ & 0.25 & 0.9, ebb \\
\hline & $\begin{array}{l}\text { Emmanuelle } \\
\text { Tomassos }\end{array}$ & $23217,16.1$ & 0.35 & 0.2 , weak ebb \\
\hline & Essen Express & $53815,11.9$ & 0.5 & 0.3 , weak ebb \\
\hline \multirow{12}{*}{$\begin{array}{l}\text { Outbound/Stage } \\
>7 \mathrm{ft} \text { MLLW }\end{array}$} & YM South & $46697,12.2$ & 0.5 & 7.3, ebb \\
\hline & Maersk Garonne & $50698,13.5$ & 0.7 & 7.0, ebb \\
\hline & Kyriakoula & $40680,10.9$ & 0.45 & 7.1, flood \\
\hline & Mol America & $16803,14.3$ & 0.35 & 8.3, top \\
\hline & Mol Elbe & $50352,11.9$ & 0.35 & 9.1, top \\
\hline & MSC Christina & $37579,12.7$ & 0.75 & 8.7, weak ebb \\
\hline & Zim Iberia & $41507,13.0$ & 0.95 & 8.8, top \\
\hline & Darya Rani & $26054,11.3$ & 0.2 & 8.6, weak ebb \\
\hline & Victoria Bridge & $53400,11.2$ & 0.65 & 7.9, flood \\
\hline & Hanjin Wilmington & $51754,12.5$ & 1.1 & 8.6, top \\
\hline & Mol Velocity & $53519,13.3$ & 1.35 & 8.7, top \\
\hline & Kavo Alexandros II & $16608,11.3$ & 0.25 & 8.7, top \\
\hline
\end{tabular}

Summarizing, TI experiences ship effects at both high tides over the south jetty as well as low tides below the top of the south jetty. Ship effects are caused by long period drawdown that moves from the ship channel to the TI shoreline. The drawdown causes a variety of effects when reaching the shallow shoreline area including 6-8 sec period waves having heights of up to $1 \mathrm{ft}$ and/ or surge above the still-water level. Drawdown magnitude at the TI shoreline is almost always less than that measured for the same ship at FP.

The design ship analysis for TI will be similar to the FP analysis, but only drawdown will be used to quantify ship effects. In the TI cross section in Figure 5, the channel width at a bottom contour of - $15 \mathrm{ft}$ MLLW is $1,620 \mathrm{ft}$ and the effective channel area at a mean tide level of $3.7 \mathrm{ft}$ MLLW is $64,175 \mathrm{sq} \mathrm{ft}$. With the navigation channel deepened to - $50 \mathrm{ft}$ MLLW, the effective channel area is $66,793 \mathrm{sq} \mathrm{ft}$ and effective width remains at $1,620 \mathrm{ft}$. The increase in effective area is only about 4.3 percent. The effective areas and widths at FP and TI are almost identical. The typical 
speed of the design ships in the existing channel is set equal to the observed average speed from the field study of 12.9 knots. A faster design ship traveling at 1.5 knots greater than the typical speed will also be used in the analysis. An increase of 1.5 knots at TI was used because the Schijf equation for return velocity and drawdown does not apply using a 2-knot increase. This is not significant because a 1.5- versus a 2-knot speed increase will not affect the findings. Both the typical (80 percent of design draft) and design draft will be used in the analysis as shown in Table 15. In all cases, the design ship in the deepened channel had slightly less drawdown than the existing channel. Note that the computed drawdown is based on the ship located inside the jetties whereas the actual drawdown at TI shoreline may be generated while the ship is outside the jetties. The Table 15 values are for comparison purposes of without- and with-project. The Table 15 drawdown is generally much larger than the values that were measured at the location 4,500 $\mathrm{ft}$ away from the center of the ship channel. In the field data, drawdown for all tests in Table 14 averaged $0.55 \mathrm{ft}$ compared to PA ships in the existing channel at typical speeds having drawdown of $1.62 \mathrm{ft}$. Based on this comparison, drawdown magnitude at TI shoreline will be about one-third of drawdown computed for the ship between the jetties shown in Table 15.

Table 15. Design ship analysis for Tybee Island. Return velocity and drawdown are averages over cross section based on Schijf equation.

\begin{tabular}{|l|l|l|l|l|l|}
\hline $\begin{array}{l}\text { Design Ship / } \\
\text { channel }\end{array}$ & Ship & $\begin{array}{l}\text { Typical ship } \\
\text { speed, knots }\end{array}$ & $\begin{array}{l}\text { High ship } \\
\text { speed, knots }\end{array}$ & $\begin{array}{l}\text { Drawdown for } \\
\text { typical speed, ft }\end{array}$ & $\begin{array}{l}\text { Drawdown for } \\
\text { high speed, ft }\end{array}$ \\
\hline $\begin{array}{l}\text { Typical (80\%) draft/ } \\
\text { existing (64175)* }\end{array}$ & $\begin{array}{l}\text { PP-1044 X } \\
140 \times 36.2\end{array}$ & 12.9 & 14.4 & 2.85 & 4.01 \\
\cline { 2 - 6 } & $\begin{array}{l}\text { PA-951 X } 106 \\
\text { X 32.6 }\end{array}$ & 12.9 & 14.4 & 1.62 & 2.78 \\
\cline { 2 - 6 } & $\begin{array}{l}\text { SP-716 X 99.8 } \\
\text { X 30.2 }\end{array}$ & 12.9 & 14.4 & 1.36 & 2.24 \\
\cline { 2 - 6 } & $\begin{array}{l}\text { HS-579 X 85.1 } \\
\text { X 25.4 }\end{array}$ & 12.9 & 14.4 & 0.91 & 1.42 \\
\cline { 2 - 6 } & $\begin{array}{l}\text { FM-428 X 67.7 } \\
\text { X 20.2 }\end{array}$ & 12.9 & 14.4 & 0.54 & 0.82 \\
\hline $\begin{array}{l}\text { Typical (80\%) draft/ } \\
\text { deepened (66793) }\end{array}$ & $\begin{array}{l}\text { PP-1044 X } \\
140 \times 36.2\end{array}$ & 13.15 & 14.55 & 2.76 & 3.95 \\
\cline { 2 - 6 } & $\begin{array}{l}\text { PA-951 X 106 } \\
\text { X 32.6 }\end{array}$ & 13.05 & 14.65 & 1.55 & 2.66 \\
\cline { 2 - 6 } & $\begin{array}{l}\text { SP-716 X 99.8 } \\
\text { X 30.2 }\end{array}$ & 13.05 & 14.6 & 1.3 & 2.13 \\
\cline { 2 - 6 } & $\begin{array}{l}\text { HS-579 X 85.1 } \\
\text { X 25.4 }\end{array}$ & 13.0 & 14.55 & 0.87 & 1.35 \\
\hline
\end{tabular}




\begin{tabular}{|c|c|c|c|c|c|}
\hline $\begin{array}{l}\text { Design Ship / } \\
\text { channel }\end{array}$ & Ship & \begin{tabular}{|l|} 
Typical ship \\
speed, knots
\end{tabular} & \begin{tabular}{|l|} 
High ship \\
speed, knots
\end{tabular} & $\begin{array}{l}\text { Drawdown for } \\
\text { typical speed, } \mathrm{ft}\end{array}$ & $\begin{array}{l}\text { Drawdown for } \\
\text { high speed, } \mathrm{ft}\end{array}$ \\
\hline & $\begin{array}{l}\text { FM-428 X } 67.7 \\
\text { X } 20.2\end{array}$ & 13.0 & 14.5 & 0.52 & 0.78 \\
\hline \multirow[t]{5}{*}{$\begin{array}{l}\text { Design draft/ existing } \\
(64175)\end{array}$} & $\begin{array}{l}\text { PP-1044X } \\
140 \times 40.7 * *\end{array}$ & 12.9 & 14.4 & 3.53 & 4.46 \\
\hline & $\begin{array}{l}\text { PA-951 X } 106 \\
\text { X 40.7 }\end{array}$ & 12.9 & 14.4 & 2.21 & 3.47 \\
\hline & $\begin{array}{l}\text { SP-716 X } 99.8 \\
\text { X } 37.7\end{array}$ & 12.9 & 14.4 & 1.82 & 3.08 \\
\hline & $\begin{array}{l}\text { HS-579 X } 85.1 \\
\text { X } 31.8\end{array}$ & 12.9 & 14.4 & 1.19 & 1.92 \\
\hline & $\begin{array}{l}\text { FM-428 X } 67.7 \\
\text { X } 25.2\end{array}$ & & & 0.7 & 1.07 \\
\hline \multirow[t]{5}{*}{$\begin{array}{l}\text { Design draft/ } \\
\text { deepened (66793) }\end{array}$} & $\begin{array}{l}\text { PP-1044X } \\
140 \times 45.3\end{array}$ & 12.55 & 13.6 & 3.22 & 4.24 \\
\hline & $\begin{array}{l}\text { PA-951 X } 106 \\
\text { X 40.7 }\end{array}$ & 13.1 & 14.5 & 2.13 & 3.4 \\
\hline & $\begin{array}{l}\text { SP-716 X } 99.8 \\
\text { X } 37.7\end{array}$ & 13.05 & 14.6 & 1.73 & 3.01 \\
\hline & $\begin{array}{l}\text { HS-579 X } 85.1 \\
\text { X } 31.8\end{array}$ & 13.05 & 14.6 & 1.14 & 1.83 \\
\hline & $\begin{array}{l}\text { FM-428 X } 67.7 \\
\text { X } 25.2\end{array}$ & 13.0 & 14.55 & 0.66 & 1.02 \\
\hline
\end{tabular}

Tables 16-19 present the composite drawdown using the drawdown from Table 15 and the traffic frequency from Table 6 to incorporate fleet composition. Conclusions and trends are the same for 2030 and 2050 and for the four traffic scenarios. Conclusions and trends are the same using typical speed and higher ship speed. Composite drawdown is 2.3 to 5.9 percent less in the with-project (deepened) channel. 
Table 16. Composite drawdown for Tybee Island based on Table 15 and ship frequency in Table 6 for GEC traffic scenario. Values in () show percent change from without-project to with-project.

\begin{tabular}{|l|l|l|}
\hline Draft/channel/traffic year & $\begin{array}{l}\text { Composite drawdown for } \\
\text { typical speed, ft }\end{array}$ & $\begin{array}{l}\text { Composite drawdown for } \\
\text { high speed, ft }\end{array}$ \\
\hline Typical Draft/existing/2030 & 1.63 & 2.73 \\
\hline Typical Draft/deepened/2030 & $1.56(-4.3 \%)$ & $2.62(-4.0 \%)$ \\
\hline Design Draft/existing/2030 & 2.19 & 3.4 \\
\hline Design Draft/deepened/2030 & $2.10(-4.1 \%)$ & $3.32(-2.4 \%)$ \\
\hline Typical Draft/existing/2050 & 1.62 & 2.73 \\
\hline Typical Draft/deepened/2050 & $1.55(-4.3 \%)$ & $2.62(-4.0 \%)$ \\
\hline Design Draft/existing/2050 & 2.19 & 3.42 \\
\hline Design Draft/deepened/2050 & $2.10(-4.1 \%)$ & $3.34(-2.3 \%)$ \\
\hline
\end{tabular}

Table 17. Composite drawdown for Tybee Island based on Table 15 and ship frequency in Table 6 for 10 percent traffic scenario. Values in () show percent change from without-project to with-project.

\begin{tabular}{|l|l|l|}
\hline Draft/channel/ traffic year & $\begin{array}{l}\text { Composite drawdown for } \\
\text { typical speed, ft }\end{array}$ & $\begin{array}{l}\text { Composite drawdown for } \\
\text { high speed, ft }\end{array}$ \\
\hline Typical Draft/existing/2030 & 1.73 & 2.84 \\
\hline Typical Draft/deepened/2030 & $1.66(-4.0 \%)$ & $2.73(-3.9 \%)$ \\
\hline Design Draft/existing/2030 & 2.31 & 3.49 \\
\hline Design Draft/deepened/2030 & $2.20(-4.8 \%)$ & $3.40(-2.6 \%)$ \\
\hline Typical Draft/existing/2050 & 1.73 & 2.84 \\
\hline Typical Draft/deepened/2050 & $1.66(-4.0 \%)$ & $2.74(-3.5 \%)$ \\
\hline Design Draft/existing/2050 & 2.31 & 3.50 \\
\hline Design Draft/deepened/2050 & $2.20(-4.8 \%)$ & $3.41(-2.6 \%)$ \\
\hline
\end{tabular}

Table 18. Composite drawdown for Tybee Island based on Table 15 and ship frequency in Table 6 for 20 percent traffic scenario. Values in () show percent change from without-project to with-project.

\begin{tabular}{|l|l|l|}
\hline Draft/channel/ traffic year & $\begin{array}{l}\text { Composite drawdown for } \\
\text { typical speed, ft }\end{array}$ & $\begin{array}{l}\text { Composite drawdown for } \\
\text { high speed, ft }\end{array}$ \\
\hline Typical Draft/existing/2030 & 1.84 & 2.95 \\
\hline Typical Draft/deepened/2030 & $1.77(-3.8 \%)$ & $2.84(-3.7 \%)$ \\
\hline Design Draft/existing/2030 & 2.43 & 3.58 \\
\hline Design Draft/deepened/2030 & $2.29(-5.8 \%)$ & $3.47(-3.1 \%)$ \\
\hline Typical Draft/existing/2050 & 1.84 & 2.96 \\
\hline Typical Draft/deepened/2050 & $1.77(-3.8 \%)$ & $2.85(-3.7 \%)$ \\
\hline Design Draft/existing/2050 & 2.43 & 3.59 \\
\hline Design Draft/deepened/2050 & $2.30(-5.3 \%)$ & $3.49(-2.8 \%)$ \\
\hline
\end{tabular}


Table 19. Composite drawdown for Tybee Island based on Table 15 and ship frequency in Table 6 for 30 percent traffic scenario. Values in () show percent change from without-project to with-project.

\begin{tabular}{|l|l|l|}
\hline Draft/channel/ traffic year & $\begin{array}{l}\text { Composite drawdown for } \\
\text { typical speed, ft }\end{array}$ & $\begin{array}{l}\text { Composite drawdown for } \\
\text { high speed, ft }\end{array}$ \\
\hline Typical Draft/existing/2030 & 1.95 & 3.05 \\
\hline Typical Draft/deepened/2030 & $1.88(-3.6 \%)$ & $2.96(-3.0 \%)$ \\
\hline Design Draft/existing/2030 & 2.54 & 3.66 \\
\hline Design Draft/deepened/2030 & $2.39(-5.9 \%)$ & $3.55(-3.0 \%)$ \\
\hline Typical Draft/existing/2050 & 1.95 & 3.07 \\
\hline Typical Draft/deepened/2050 & $1.88(-3.6 \%)$ & $2.97(-3.3 \%)$ \\
\hline Design Draft/existing/2050 & 2.55 & 3.68 \\
\hline Design Draft/deepened/2050 & $2.40(-5.9 \%)$ & $3.57(-3.0 \%)$ \\
\hline
\end{tabular}




\section{Confined Disposal Facility and City Front Ship Effects}

At CDF and CF, the Savannah District requested a table showing ship effects in the existing channel. Drawdown is used to quantify ship effects in the existing channel as shown in Table 20 for the CDF ships having significant effects. Field data for the Table 20 ships are presented in the Appendices. Due to the similarity of conditions at CDF and FP, an analysis for CDF like the FP analysis would likely result in the same conclusions as for FP.

Table 20. Drawdown in existing channel for CDF ships.

\begin{tabular}{|c|c|c|}
\hline Name & Date & Drawdown, $\mathrm{ft}$ \\
\hline \multicolumn{3}{|c|}{ CDF - Inbound } \\
\hline Emmanuel Tomassos & 18 & 1.1 \\
\hline Hanjin Wilmington & 18 & $1.4^{*}$ \\
\hline Essen Express & 19 & $1.5^{*}$ \\
\hline Angel Accord & 19 & 0.4 \\
\hline Mol Velocity & 19 & $2.7^{*}$ \\
\hline Stuttgart Express & 19 & 0.9 \\
\hline Ville de Taurus & 21 & 1.3 \\
\hline \multicolumn{3}{|c|}{ CDF - Outbound } \\
\hline Midnight Sun & 18 & 0.6 \\
\hline MSC Elena & 19 & $1.9 *$ \\
\hline Emmanuel Tomassos & 19 & 1.0 \\
\hline Condor & 19 & 2.0 \\
\hline Essen Express & 20 & 1.4 \\
\hline Mol Velocity & 20 & 2.4 \\
\hline Angel Accord & 20 & 1.5 \\
\hline Jervis Bay & 21 & 1.5 \\
\hline
\end{tabular}

The CF site differs from the other channel sites (CDF and FP) because ship speed, that is the most important parameter for short period waves, is too low for short period bow and stern waves to be an impact. For example, using Equation 1, only one ship at CF had computed wave height exceeding $0.5 \mathrm{ft}$. The long period drawdown will be the primary ship effect 
to quantify at $\mathrm{CF}$. The lack of significant short period bow and stern waves is the reason pressure cells were employed at the CF sites. Table 21 shows ship-induced drawdown for the CF ships. Field data for the Table 21 ships are presented in the appendices.

Table 21. Drawdown in existing channel for CF ships.

\begin{tabular}{|c|c|c|}
\hline Name & Date & Drawdown, $\mathrm{ft}$ \\
\hline \multicolumn{3}{|c|}{ CF - Inbound } \\
\hline Darya Rani & 17 & 0.2 \\
\hline Aloyna & 17 & 0.2 \\
\hline Zim Iberia & 18 & 0.2 \\
\hline Al Mariyah & 18 & 0.1 \\
\hline MSC Eleni & 18 & 0.2 \\
\hline Emmanuel Tomassos & 18 & 0.4 \\
\hline Hanjin Wilmington & 18 & 0.4 \\
\hline Condor & 18 & 0.2 \\
\hline Victoria Bridge & 19 & 0.6 \\
\hline Essen Express & 19 & 0.5 \\
\hline Angel Accord & 19 & 0.2 \\
\hline Mol Velocity & 19 & 0.4 \\
\hline Ismini & 19 & 0.6 \\
\hline Stuttgart Express & 19 & 0.5 \\
\hline CP Rome & 20 & 0.4 \\
\hline \multicolumn{3}{|c|}{ CF - Outbound } \\
\hline Jian an Cheng & 17 & 0.55 \\
\hline Mole Elbe & 17 & 0.25 \\
\hline MSC Christina & 17 & 0.3 \\
\hline Zim Israel & 17 & 0.5 \\
\hline MSC Eleni & 18 & 0.2 \\
\hline Midnight Sun & 18 & 0.2 \\
\hline Alyona & 18 & 0.3 \\
\hline Zim Iberia & 18 & 0.8 \\
\hline Darya Rani & 18 & 0.55 \\
\hline Sumida & 18 & 0.2 \\
\hline Al Mariyah & 18 & 0.2 \\
\hline MSC Elena & 19 & 0.3 \\
\hline Condor & 19 & 0.2 \\
\hline Emmanuel Tomassos & 19 & 0.1 \\
\hline Victoria Bridge & 19 & 0.7 \\
\hline Hanjin Wilmington & 19 & 0.35 \\
\hline Essen Express & 20 & 0.3 \\
\hline
\end{tabular}




\begin{tabular}{|l|l|l|}
\hline Name & Date & Drawdown, $\mathrm{ft}$ \\
\hline Mol Velocity & 20 & 0.55 \\
\hline Kavo Alexandros II & 20 & 0.2 \\
\hline Angel Accord & 20 & 0.4 \\
\hline Stuttgart Express & 20 & 0.5 \\
\hline Jervis Bay & 21 & 0.4 \\
\hline
\end{tabular}




\section{Summary and Conclusions}

Ship forces having the potential to cause shoreline erosion were evaluated at the Savannah Harbor to compare the without-project (existing) and the with-project (deepened) channels. Results of this study will be used by the Savannah District in a separate study to evaluate shoreline erosion.

An analysis of ship forces requires determination of comparable ship speeds in the without-project and with-project channels. Field data were used to determine ship speed in the without-project channel. An analytical model for ship speed, along with the assumption of equal power setting in the without-project and with-project channels, was used to determine ship speed in the with-project channel.

Based on the District's ship traffic analysis, the total number of ships will not change in without-project and with-project channels. Four traffic alternatives were evaluated that primarily differ in the number of postPanamax ships compared to Panamax ships. Without-project and withproject conditions primarily differ in draft of the post-Panamax ships and speed of all ships.

A composite value of the various ship effects was used to compare the without-project and with-project channels. The composite value is based on the magnitude of ship effect for six different vessel classes as well as the proportion of each vessel class in the overall fleet.

At Fort Pulaski, dominant ship effects include short period bow and stern waves and long period drawdown and return velocity. As shown in Tables 10-13, the composite return velocity and drawdown per ship are 3.2 to 6.2 percent less in the with-project channel. Conclusions and trends are the same for 2030 and 2050 and for the four traffic scenarios. Due to the slightly higher speed in the with-project channel, short period bow and stern waves are the shoreline attack force that increases in the with-project channel at Fort Pulaski. The composite short period bow and stern wave height per ship for years 2030 and 2050 is 1.5 to 4.4 percent greater in the deepened channel. Small changes in composite short period bow and stern waves were observed between the four traffic alternatives. 
At Tybee Island, the only significant ship effect reaching the shoreline is the long period drawdown or pressure wave. It is uncertain if the south jetty blocks ship effects at high tides because ship effects generated outside the jetties reach the TI shoreline. As shown in Tables 16-19, the composite drawdown in the channel between the jetties per ship is 2.3 to 5.9 percent less in the with-project channel. The actual drawdown at the TI shoreline will be about one-third of the drawdown in the channel between the jetties.

Ship effects were tabulated and plotted for the City Front and Confined Disposal Facility sites. 


\section{References}

Blauuw, H., F. van der Knaap, M. de Groot, and K. Pilarczyk. 1984. Design of bank protection of inland navigation fairways. Delft, The Netherlands: Delft Hydraulics Laboratory Publication No. 320.

Kamphuis, J . 1987. Recession rate of glacial till bluffs. ASCE J ournal of Waterway, Port, Coastal, and Ocean Engineering. 113 (1):60-73.

Knight, S. 1999. Wave-height predictive techniques for commercial tows on the Upper Mississippi River-Illinois Waterway System. ENV Report 15, Vicksburg, MS: U.S. Army Engineer Research and Development Center.

Maynord, S. 1996. Return velocity and drawdown in navigable waterways. Technical Report HL-96-7, Vicksburg, MS: U.S. Army Engineer Research and Development Center.

Maynord, S. 2000. Power versus speed for shallow draft navigation. ASCE J ournal of Waterway, Port, Coastal, and Ocean Engineering. 126 (2):103-106.

Maynord, S. 2003. Ship effects before and after deepening of Sabine-Neches Waterway, Port Arthur, Texas. ERDC/ CHL TR-03-15, Vicksburg, MS: U.S. Army Engineer Research and Development Center.

Sorensen, R. 1966. Ship waves. Technical report HEL-12-2. Berkeley, CA: University of California. 


\section{Appendix A: Ship Wave Height at City Front, Pressure Cell 10504}

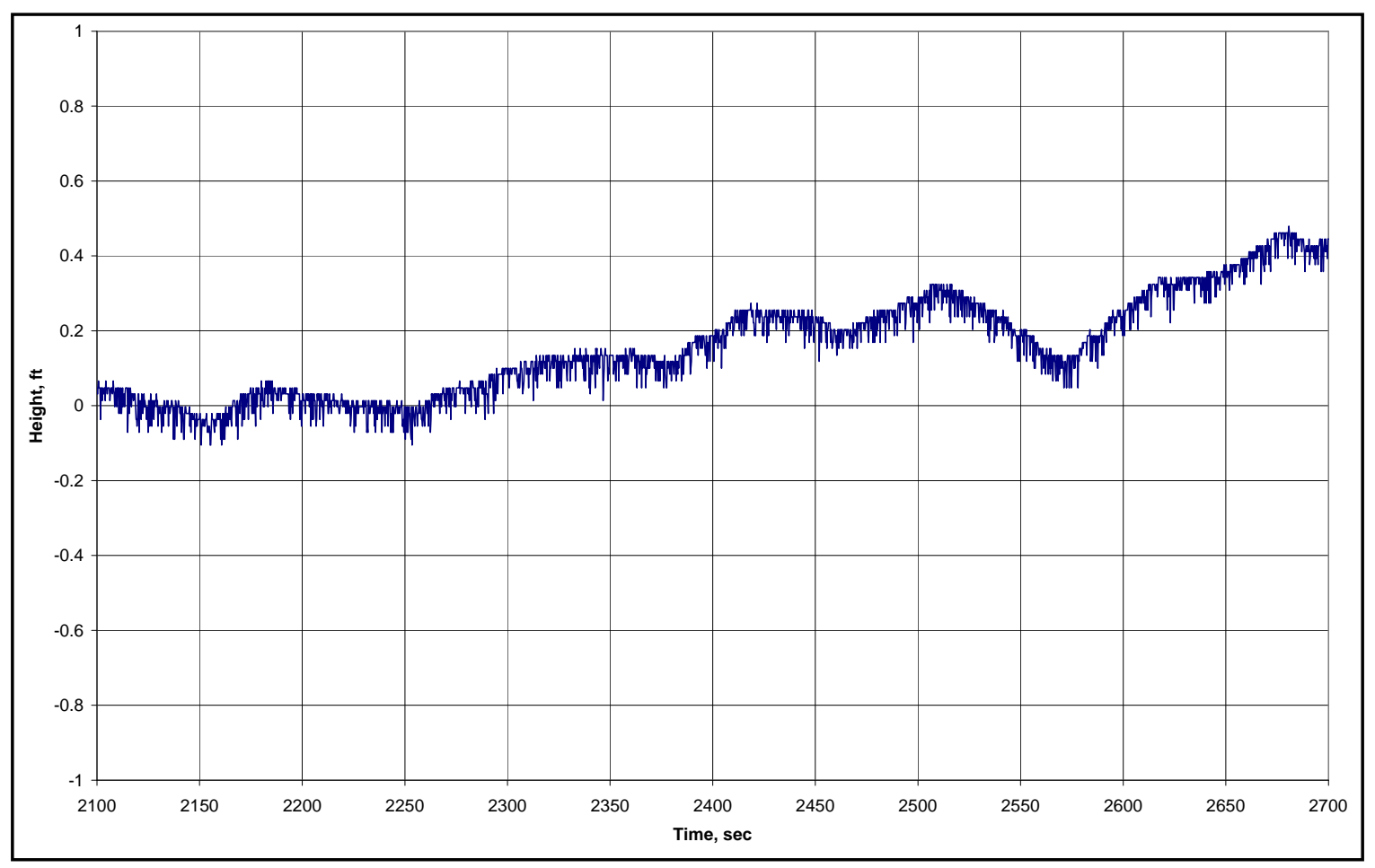

Figure A1. Darya Rani, inbound, time 0 = 1635 EDT, 17 Sep 2005. 


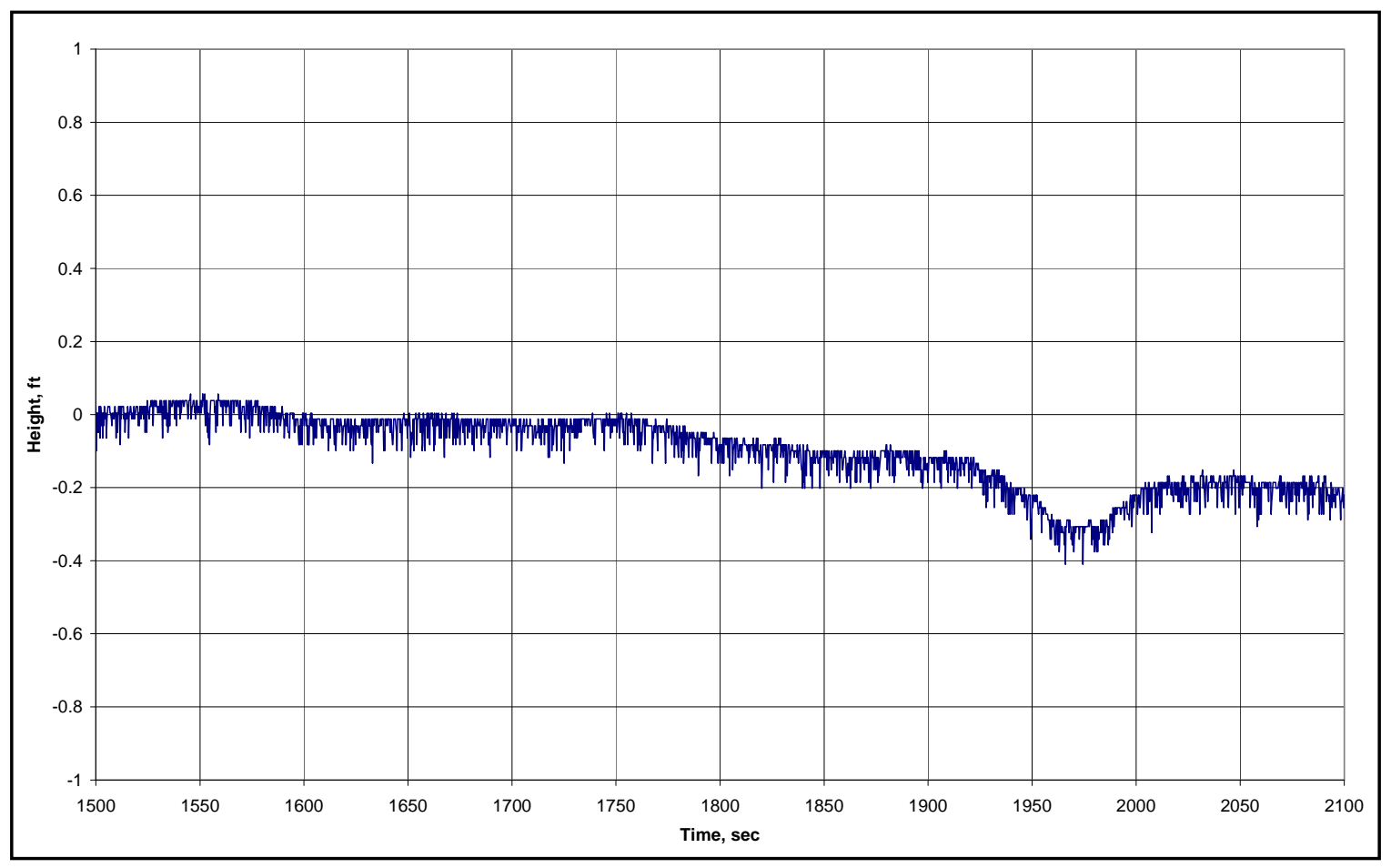

Figure A2. Aloyna, inbound, time 0 = 2200 EDT, 17 Sep 2005.

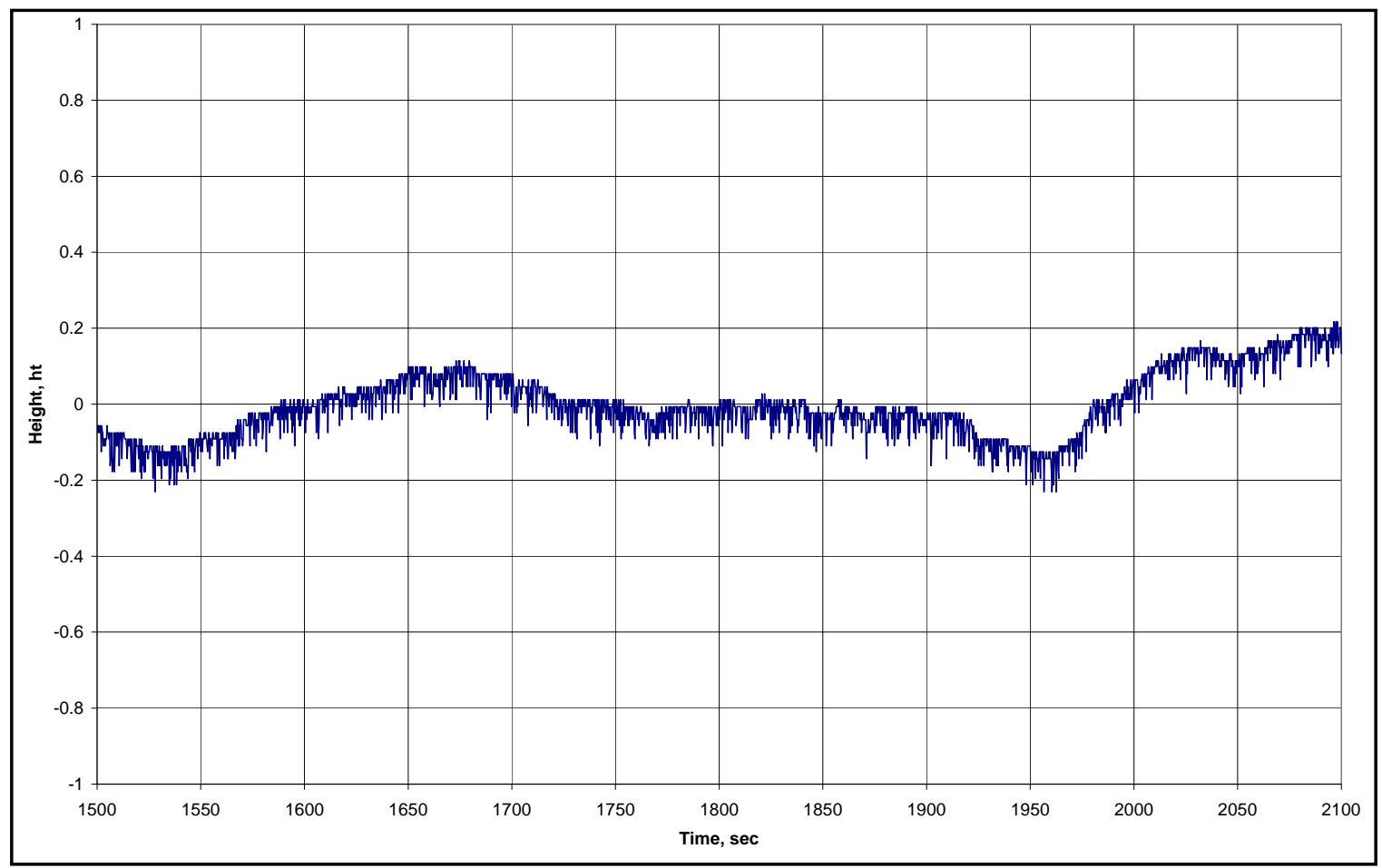

Figure A3. Zim Iberia, inbound, time $0=0400$ EDT, 18 Sep 2005. 


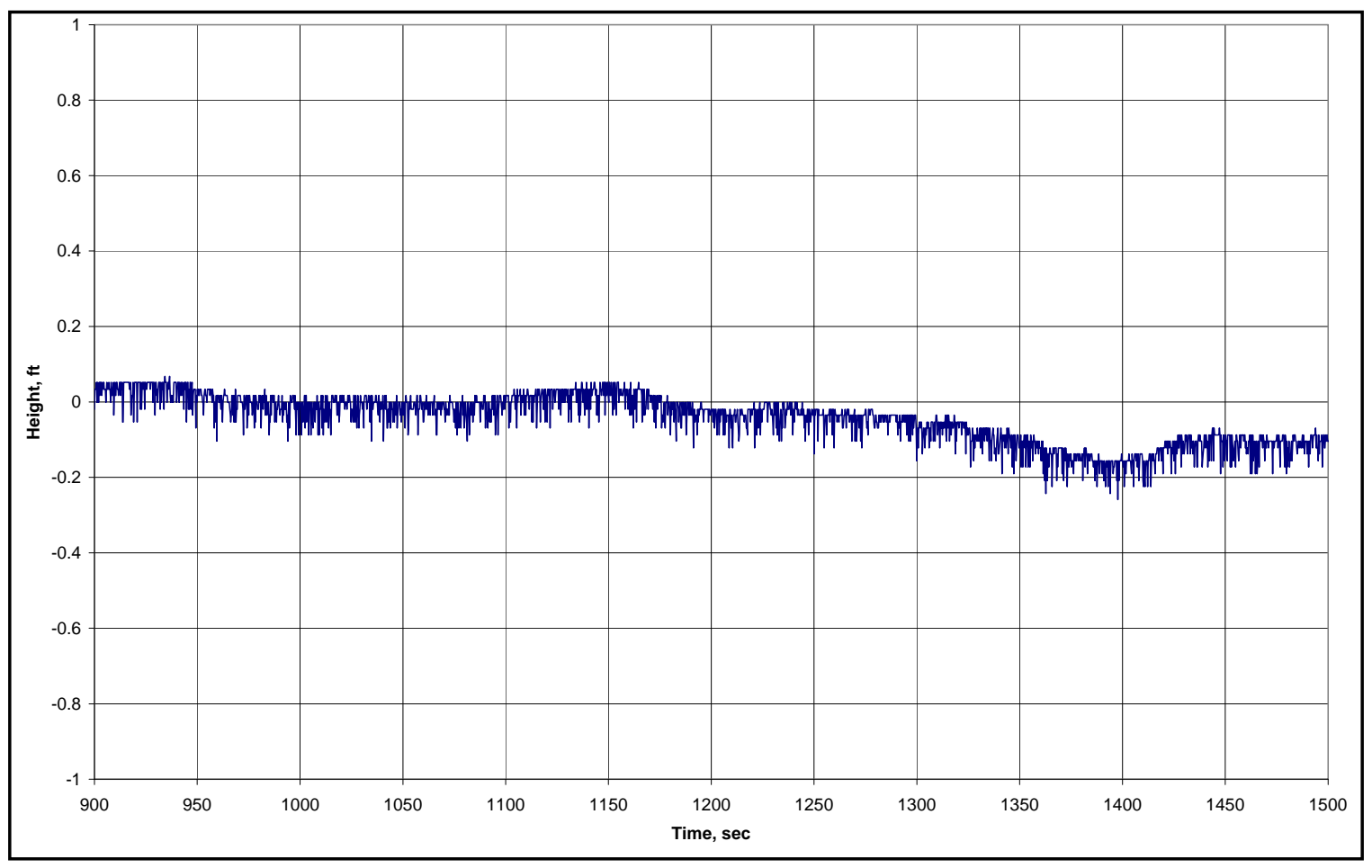

Figure A4. Al Mariyah, inbound, time 0 = 1000 EDT, 18 Sep 2005.

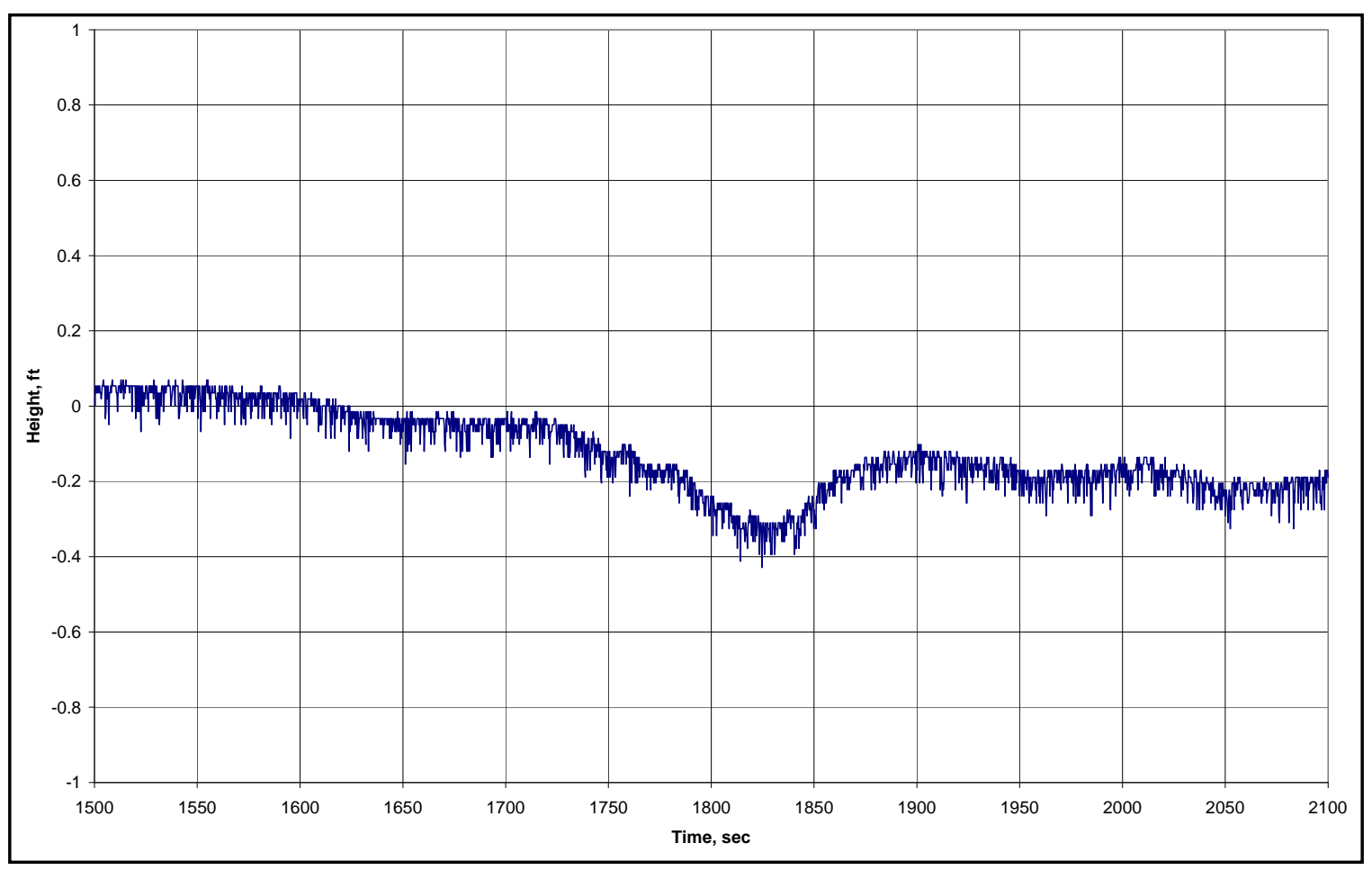

Figure A5. MSC Elena, inbound, time 0 = 1100 EDT, 18 Sep 2005. 


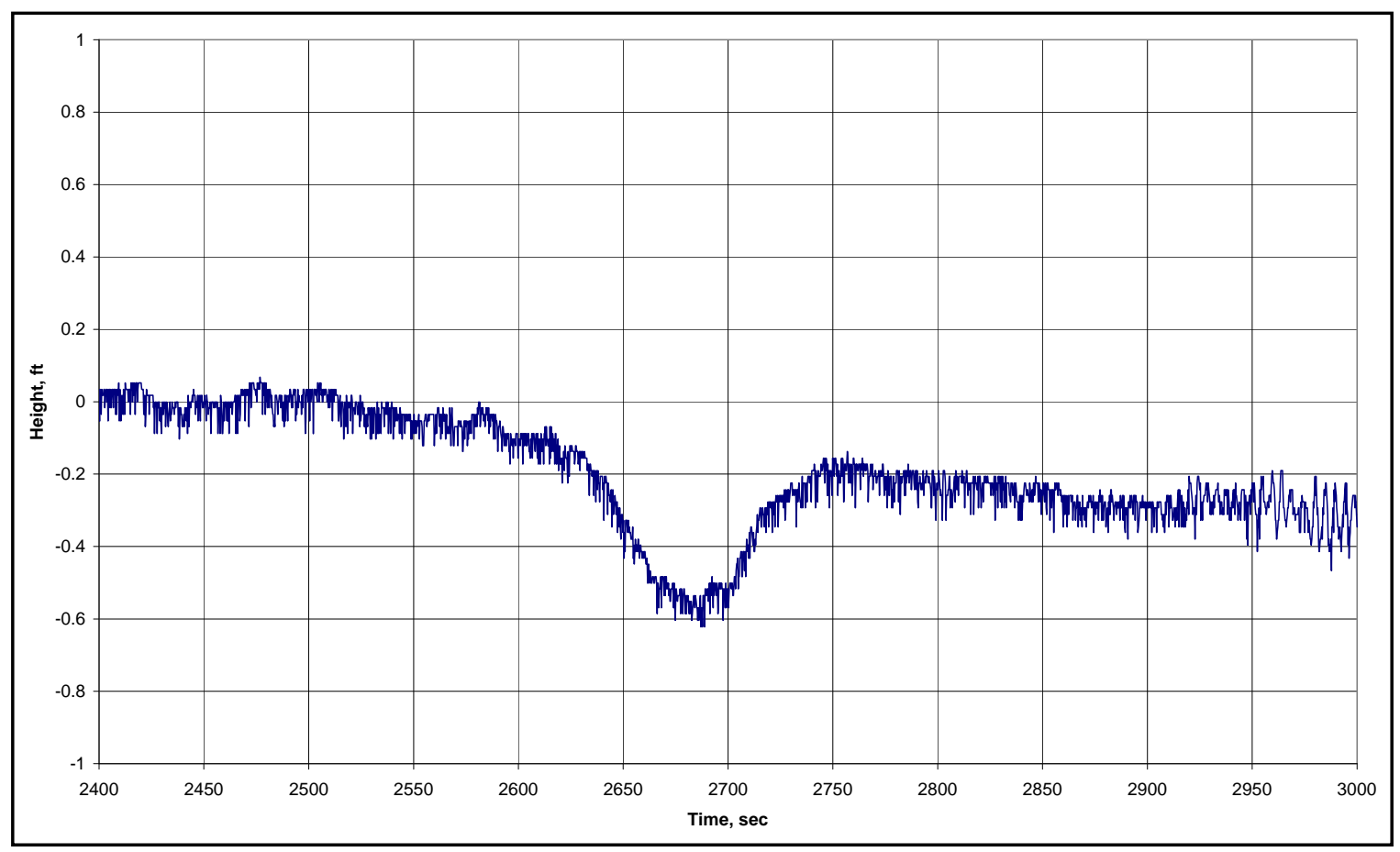

Figure A6. Emmannuelle Tomassos, inbound, time 0 = 1400 EDT, 18 Sep 2005.

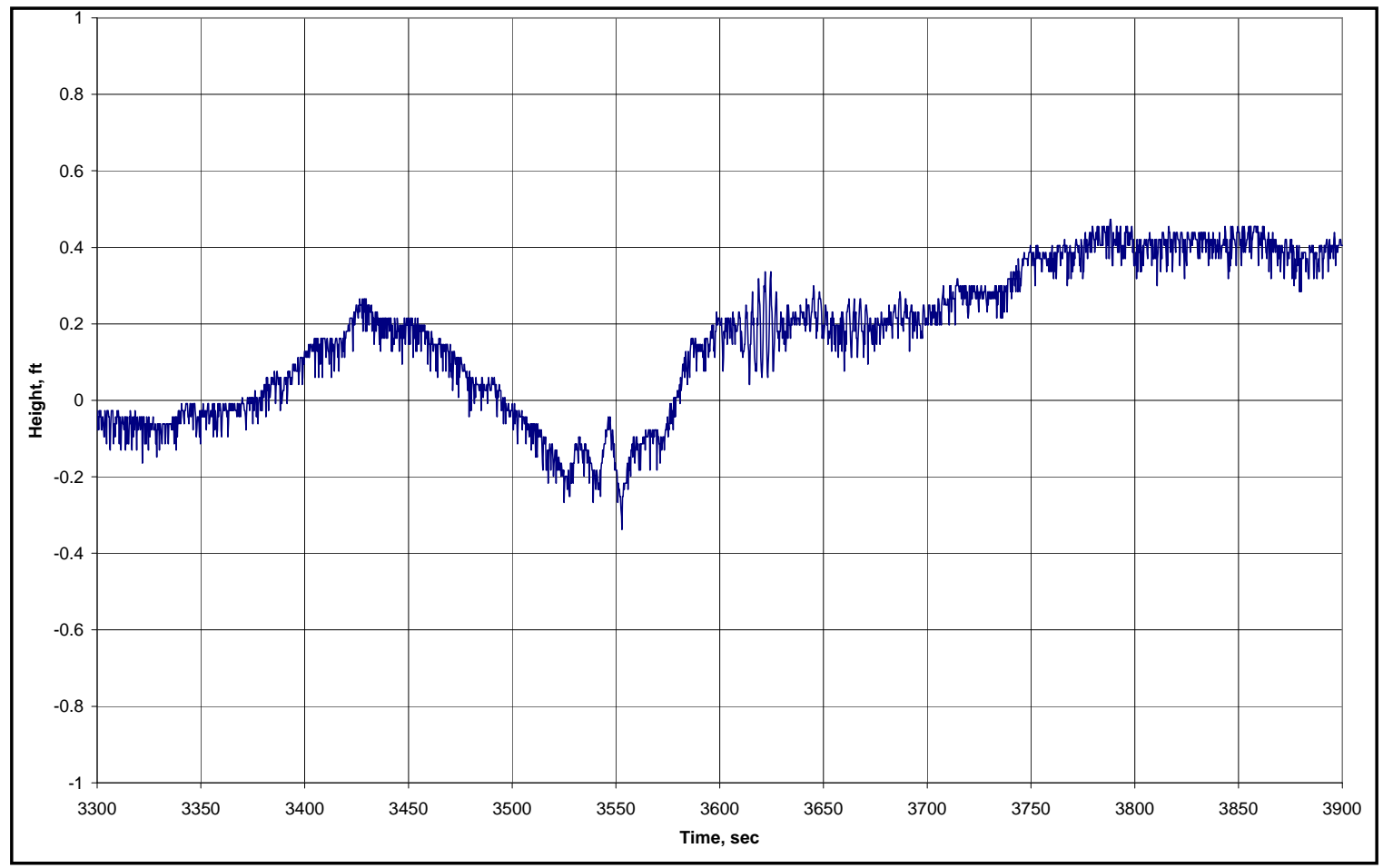

Figure A7. Hanjin Wilmington, inbound, time 0 = 1600 EDT, 18 Sep 2005. 


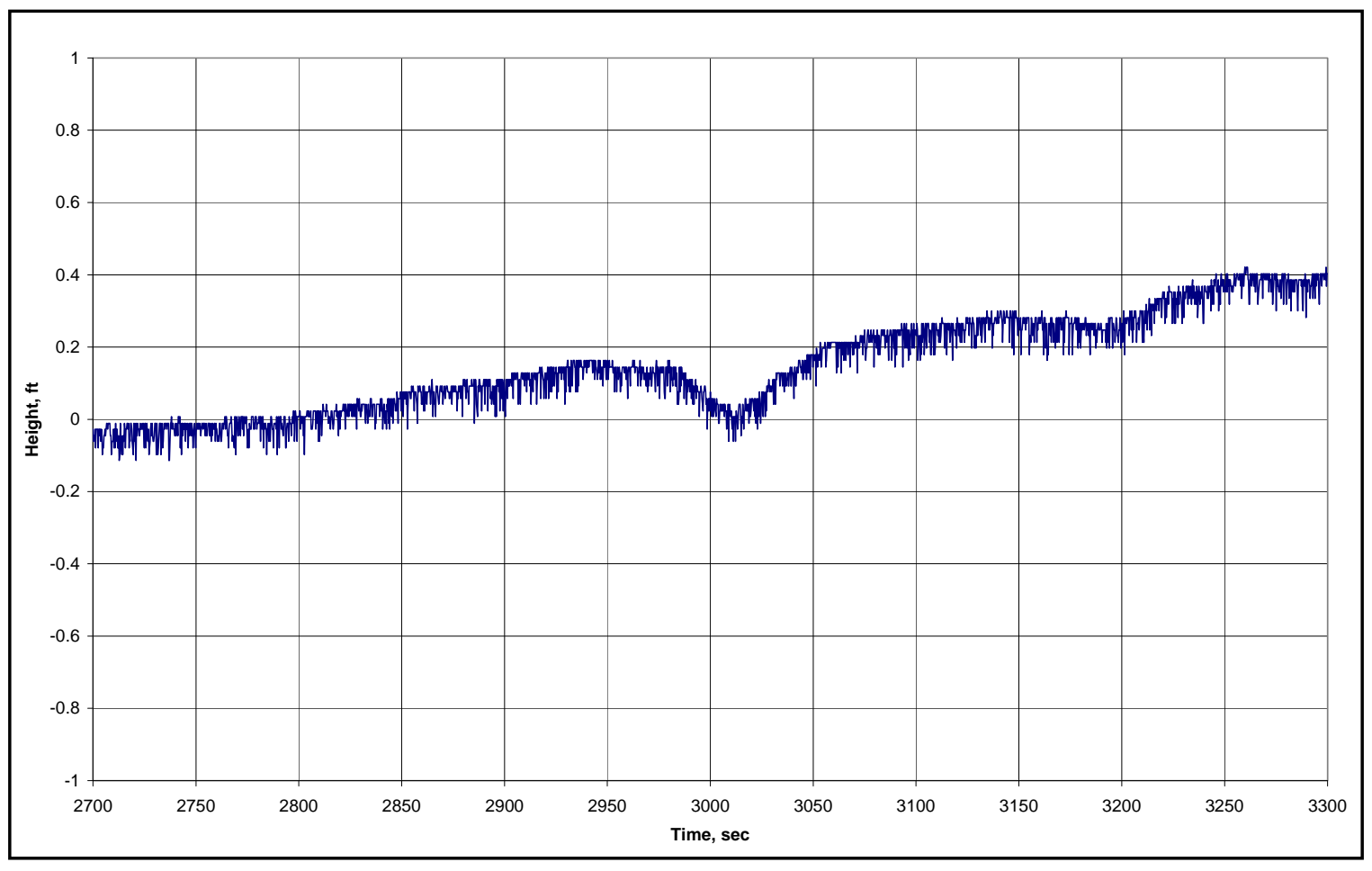

Figure A8. Condor, inbound, time 0 = 1800 EDT, 18 Sep 2005.

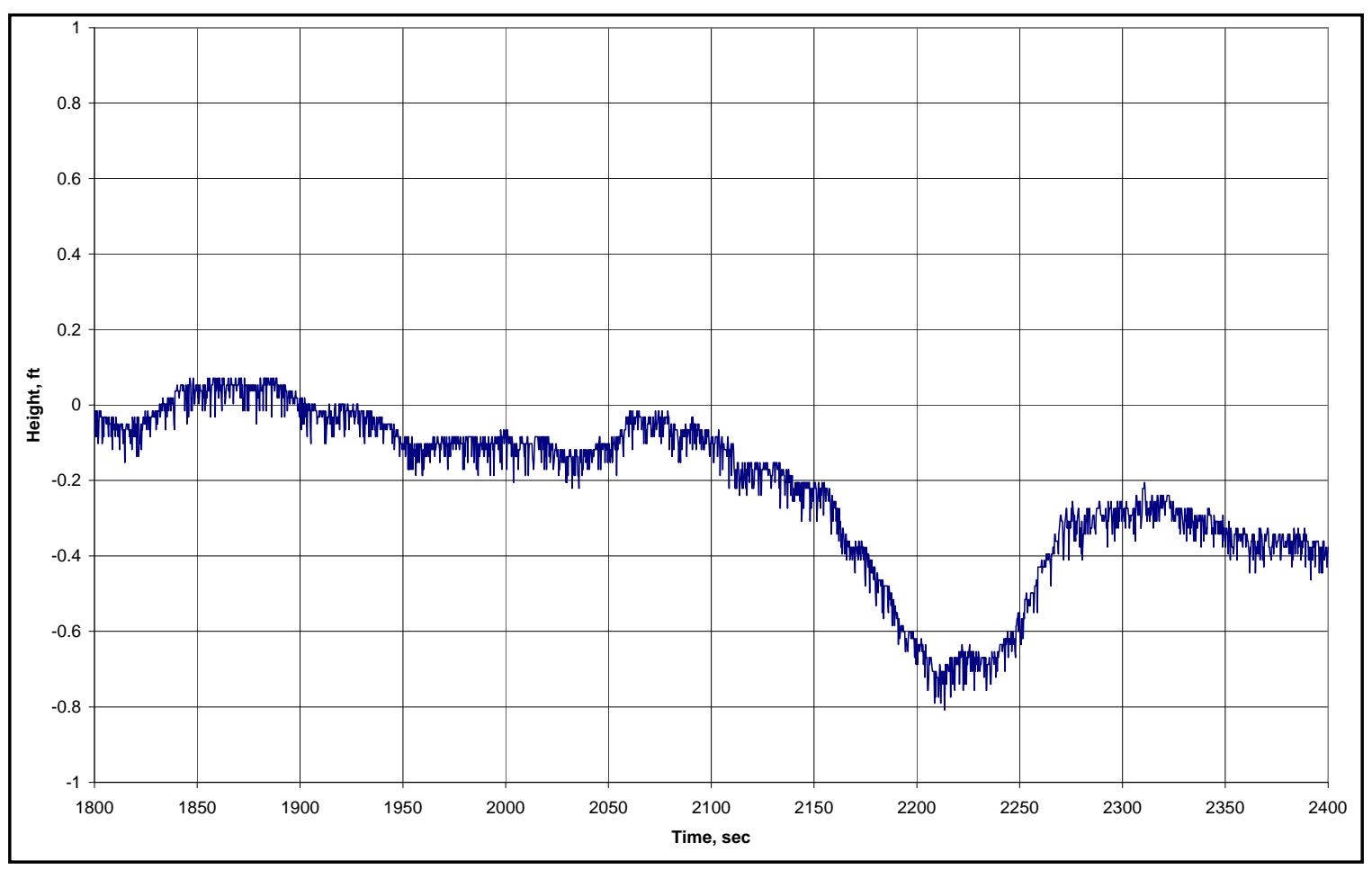

Figure A9. Victoria Bridge, inbound, time 0 = 0000 EDT, 19 Sep 2005. 
ERDC/CHL TR-07-7

58

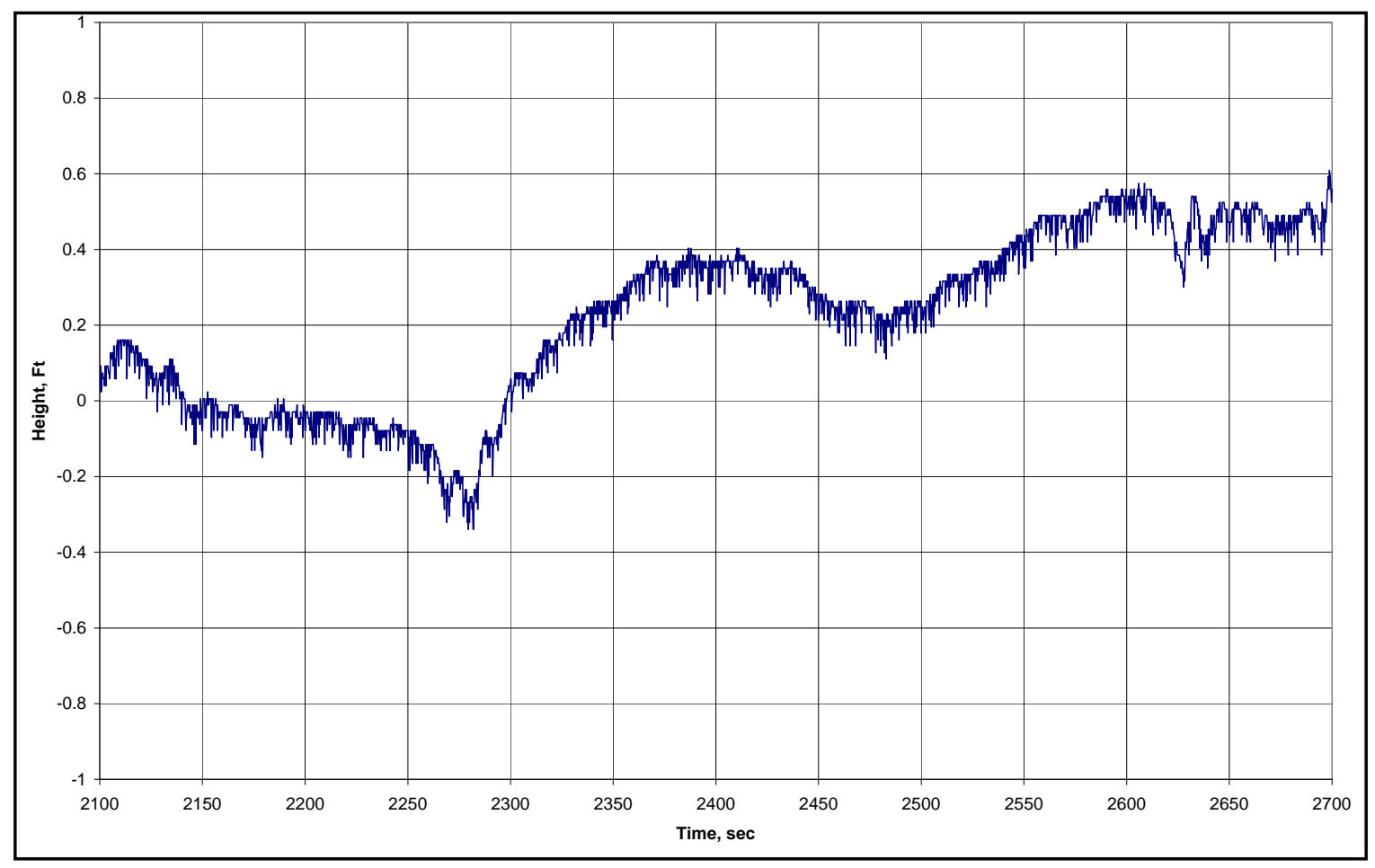

Figure A10. Essen Express, inbound, time 0 = 0500 EDT, 19 Sep 2005.

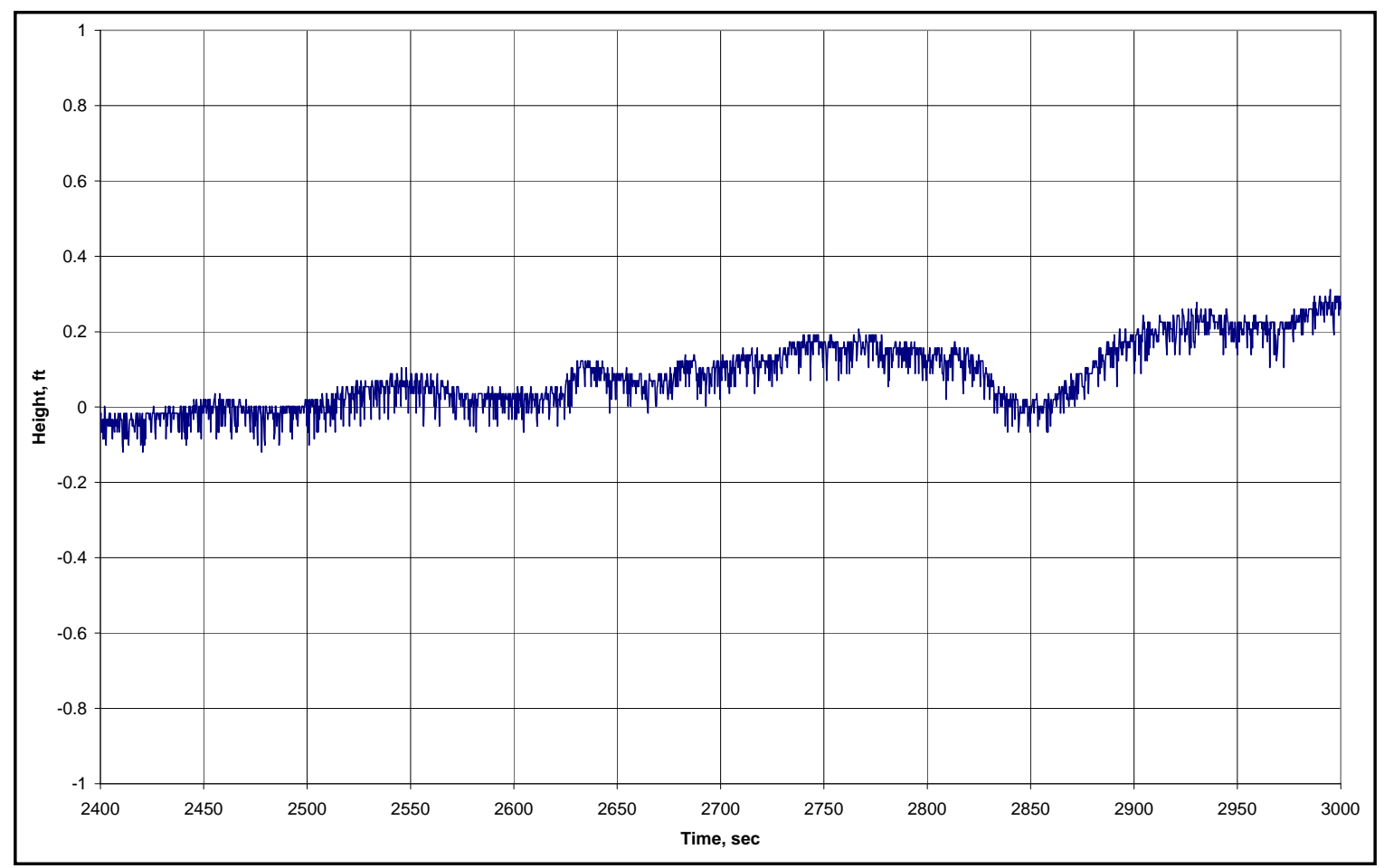

Figure A11. Angel Accord, inbound, time 0 = 1700 EDT, 19 Sep 2005. 
ERDC/CHL TR-07-7

59

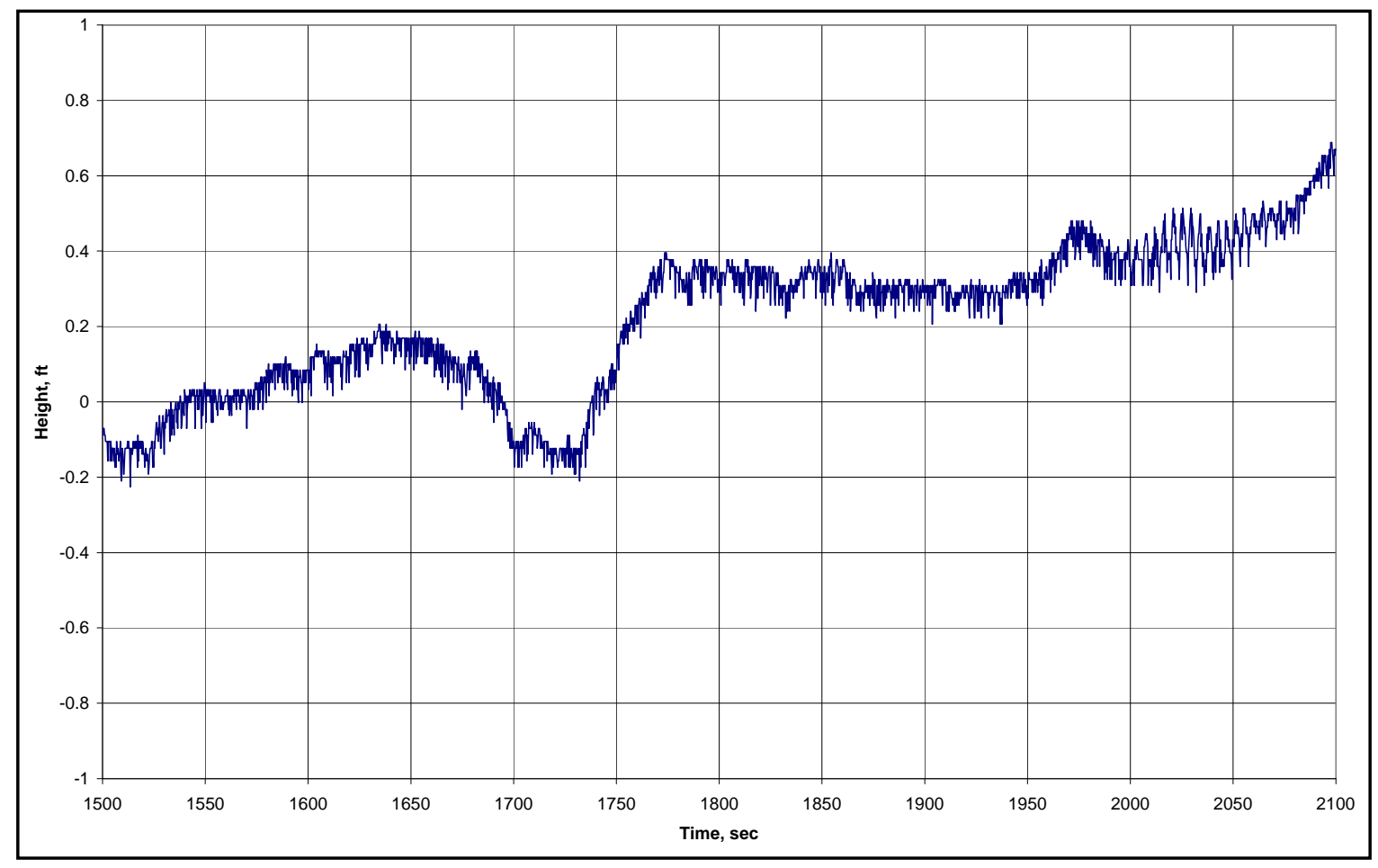

Figure A12. Mol Velocity, inbound, time 0 = 1800 EDT, 19 Sep 2005.

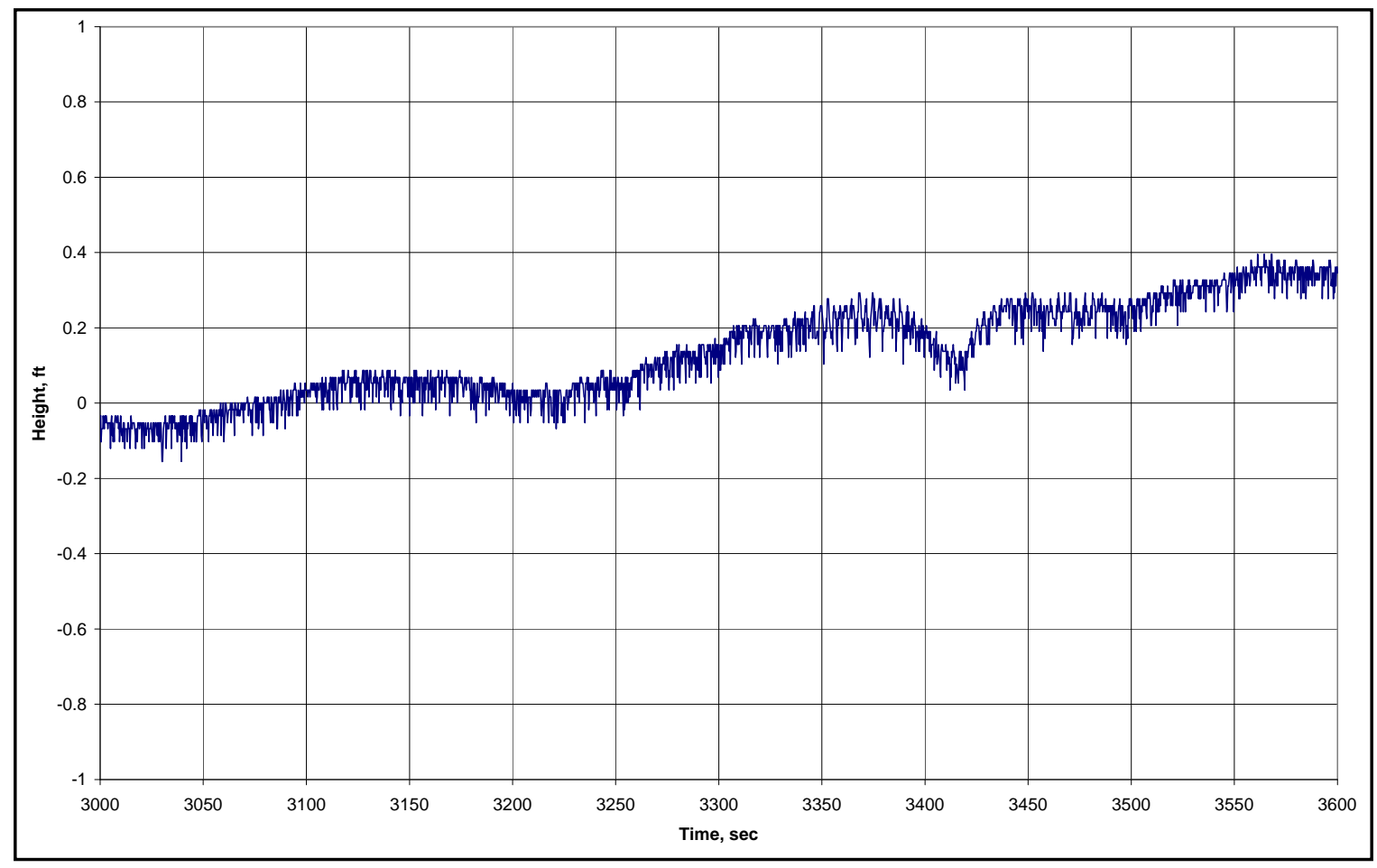

Figure A13. Antares, inbound, time 0 = 1900 EDT, 19 Sep 2005. 


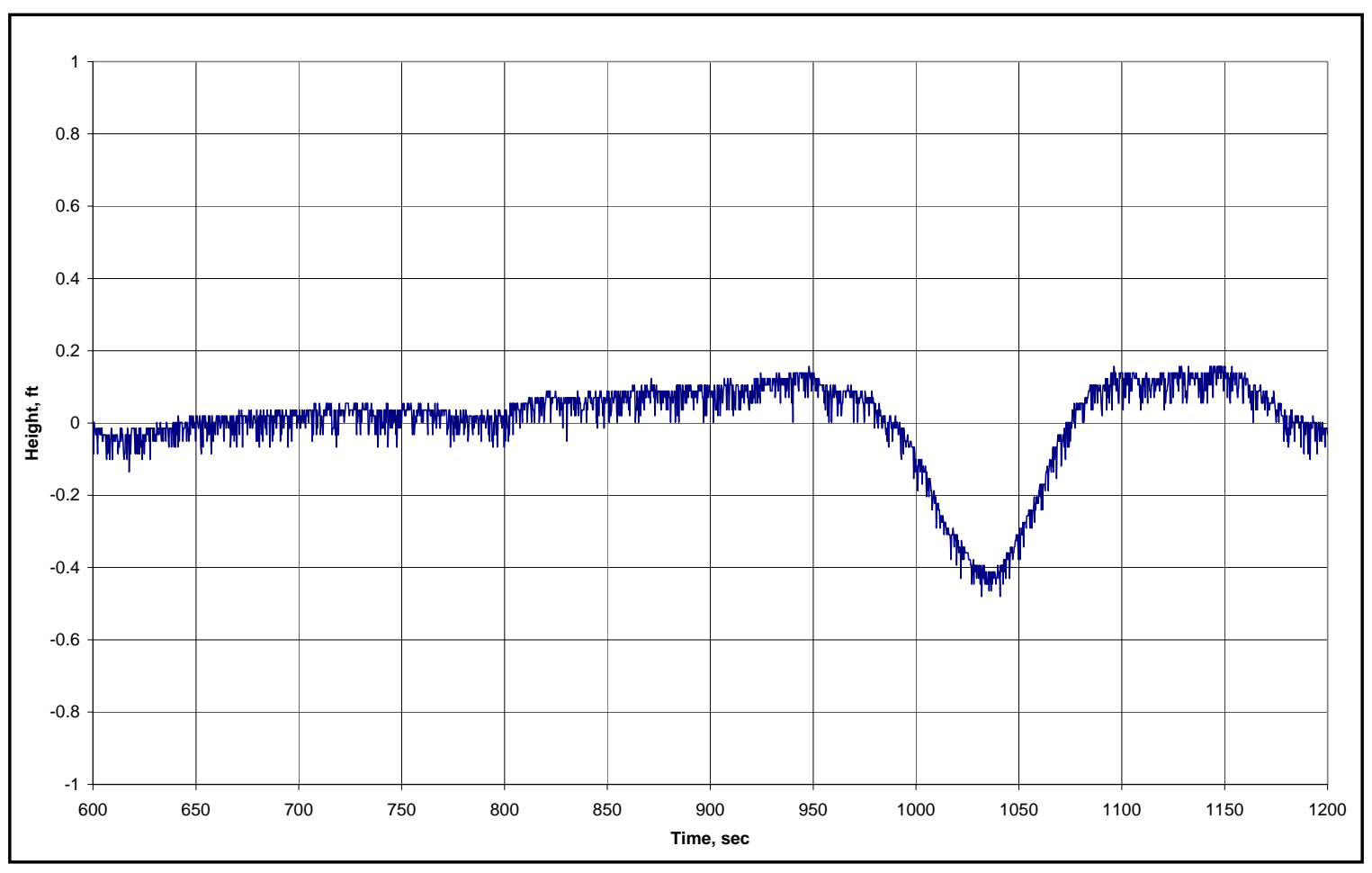

Figure A14. Ismini, inbound, time 0 = 2100 EDT, 19 Sep 2005.

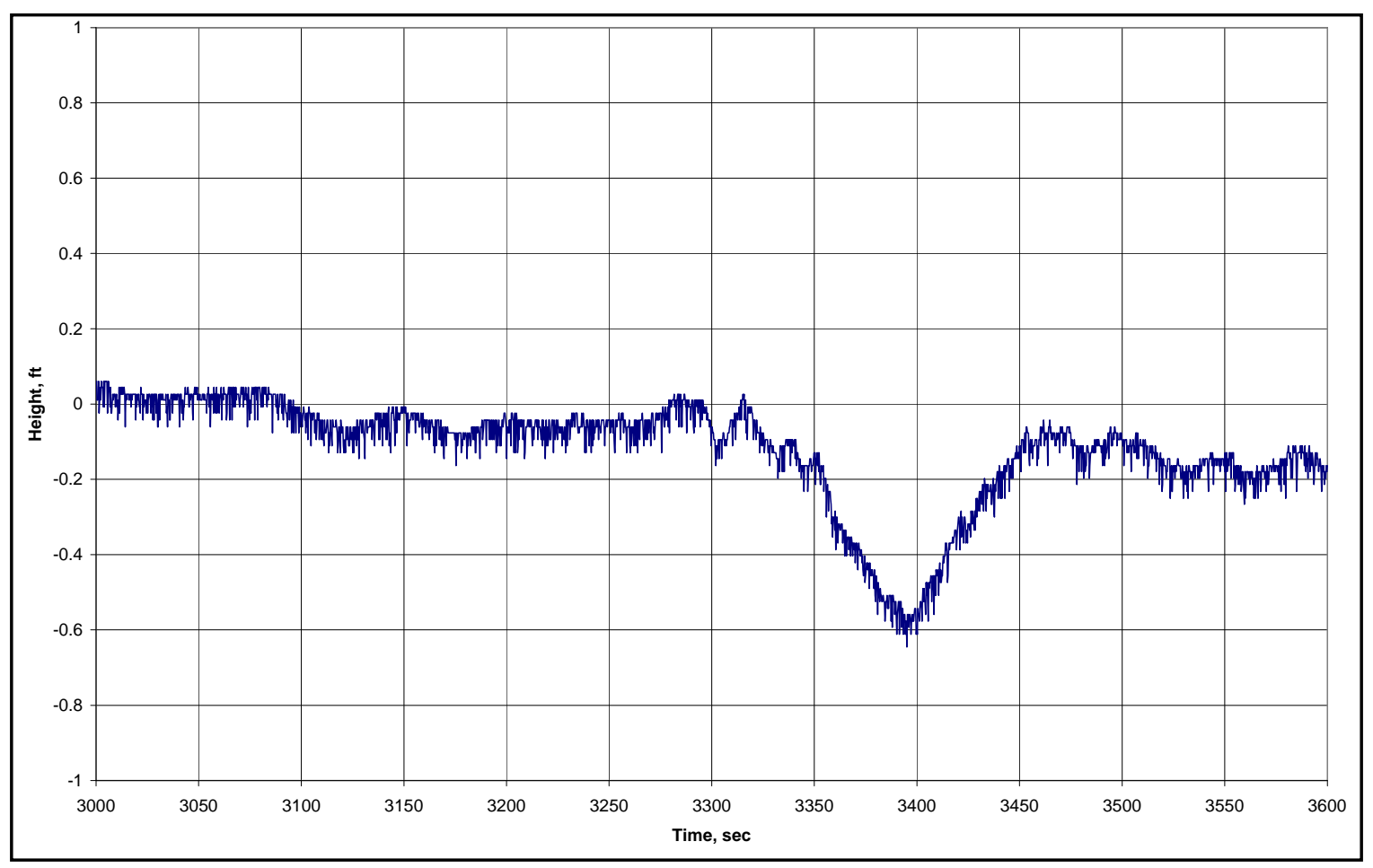

Figure A15. Stuttgart Express, inbound, time 0 = 2300 EDT, 19 Sep 2005. 


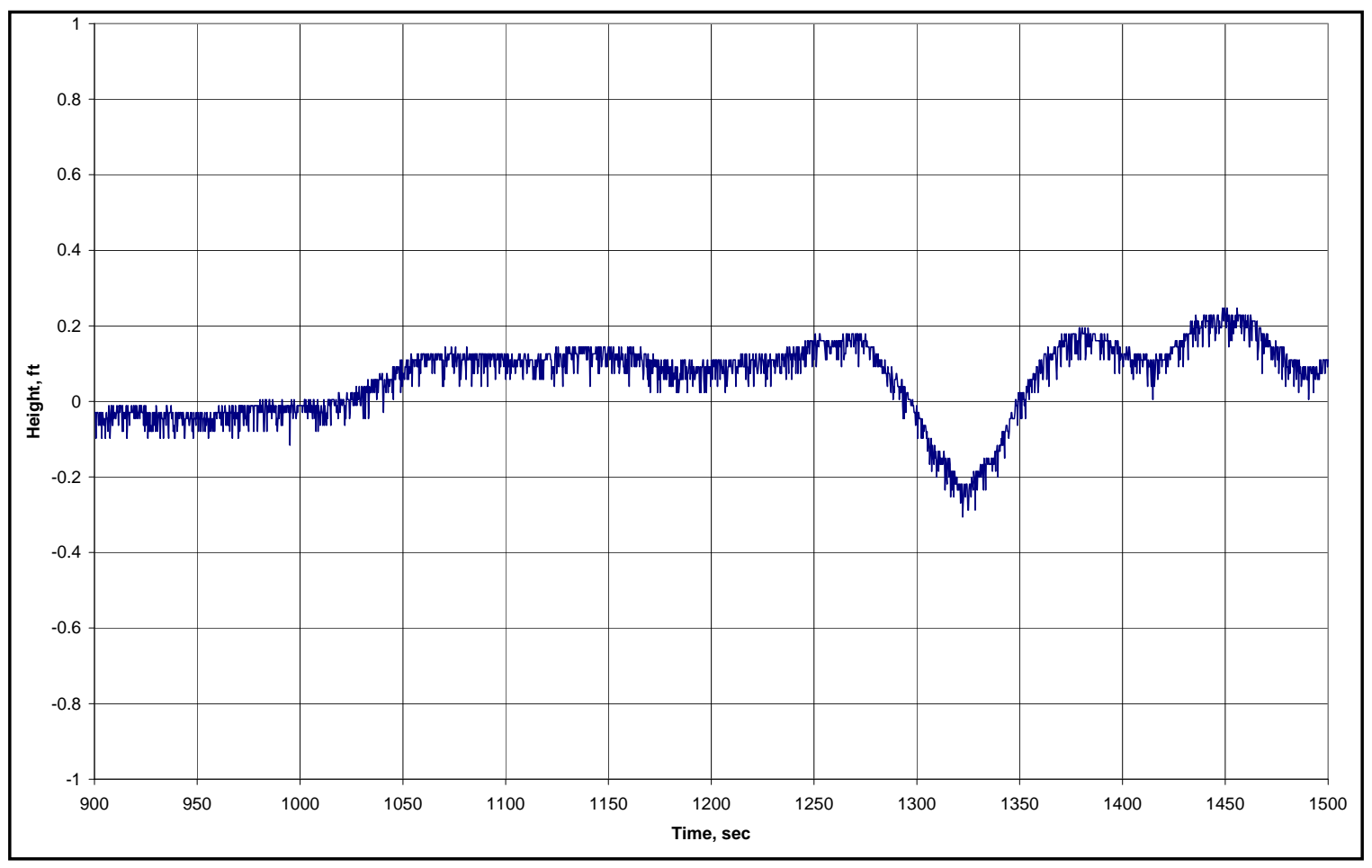

Figure A16. CP Rome, inbound, time 0 = 2100 EDT, 20 Sep 2005.

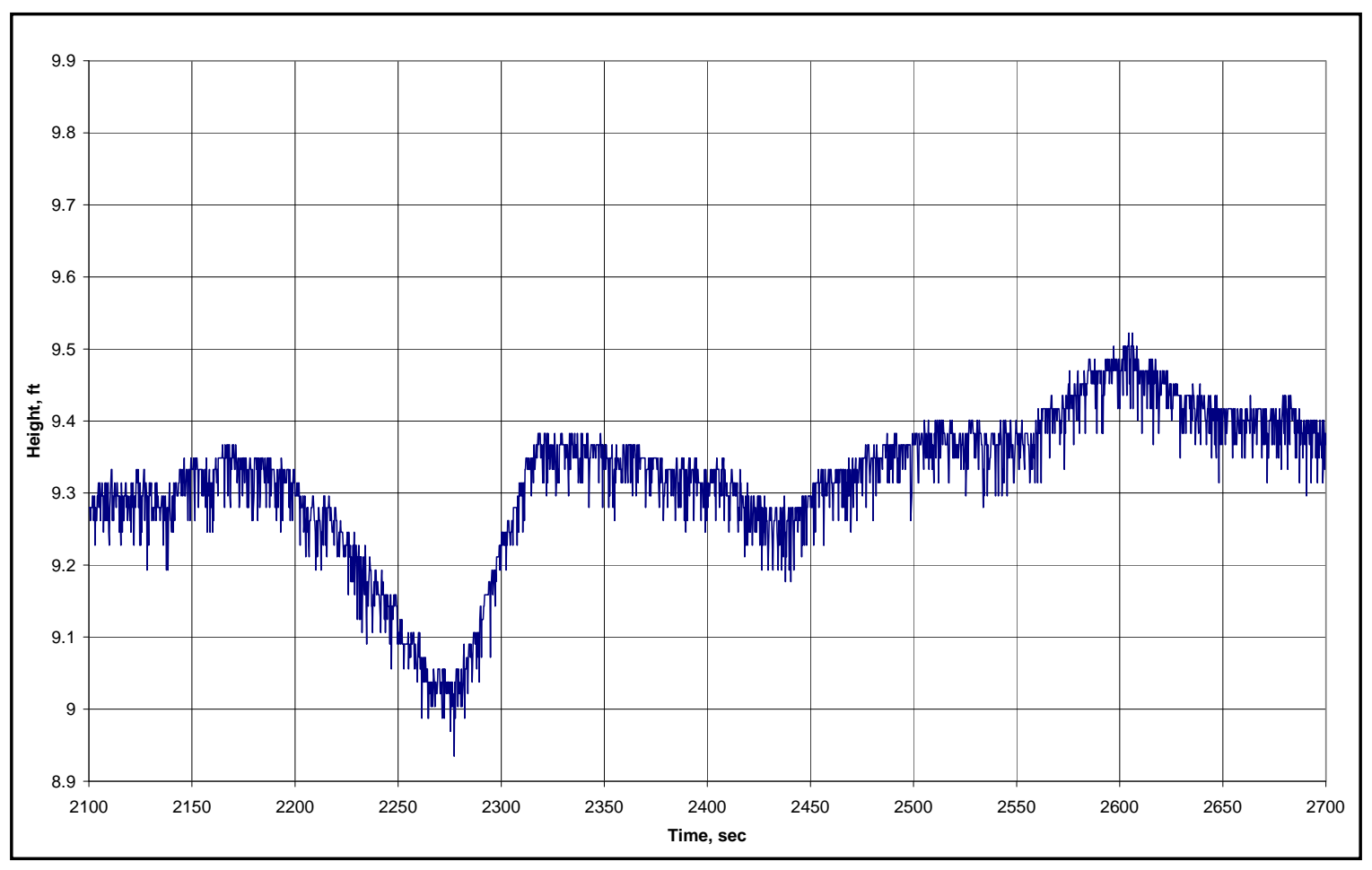

Figure A17. Jiang An Cheng, outbound, time 0 = 1500 EDT, 17 Sep 2005. 


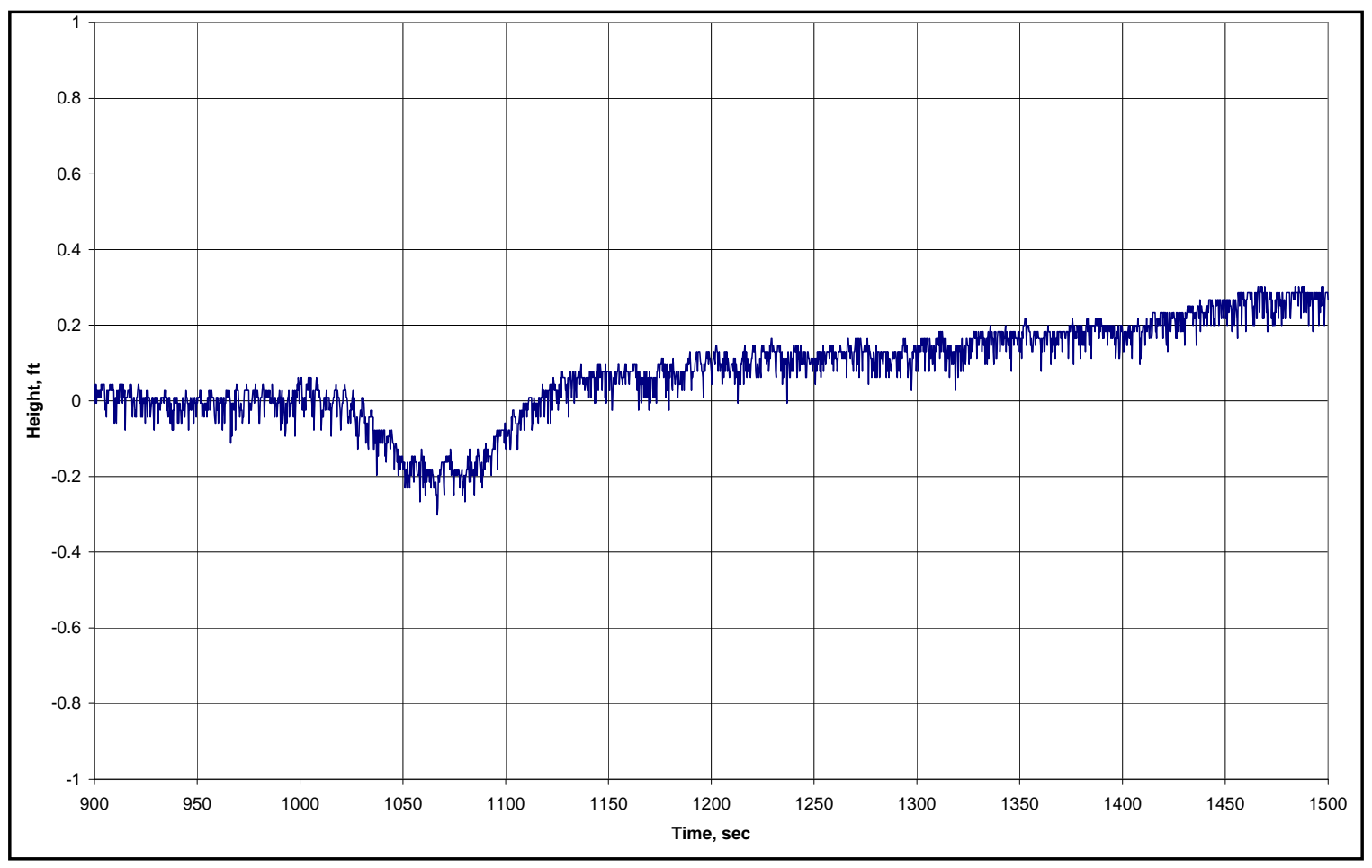

Figure A18. Mol Elbe, outbound, time 0 = 1900 EDT, 17 Sep 2005.

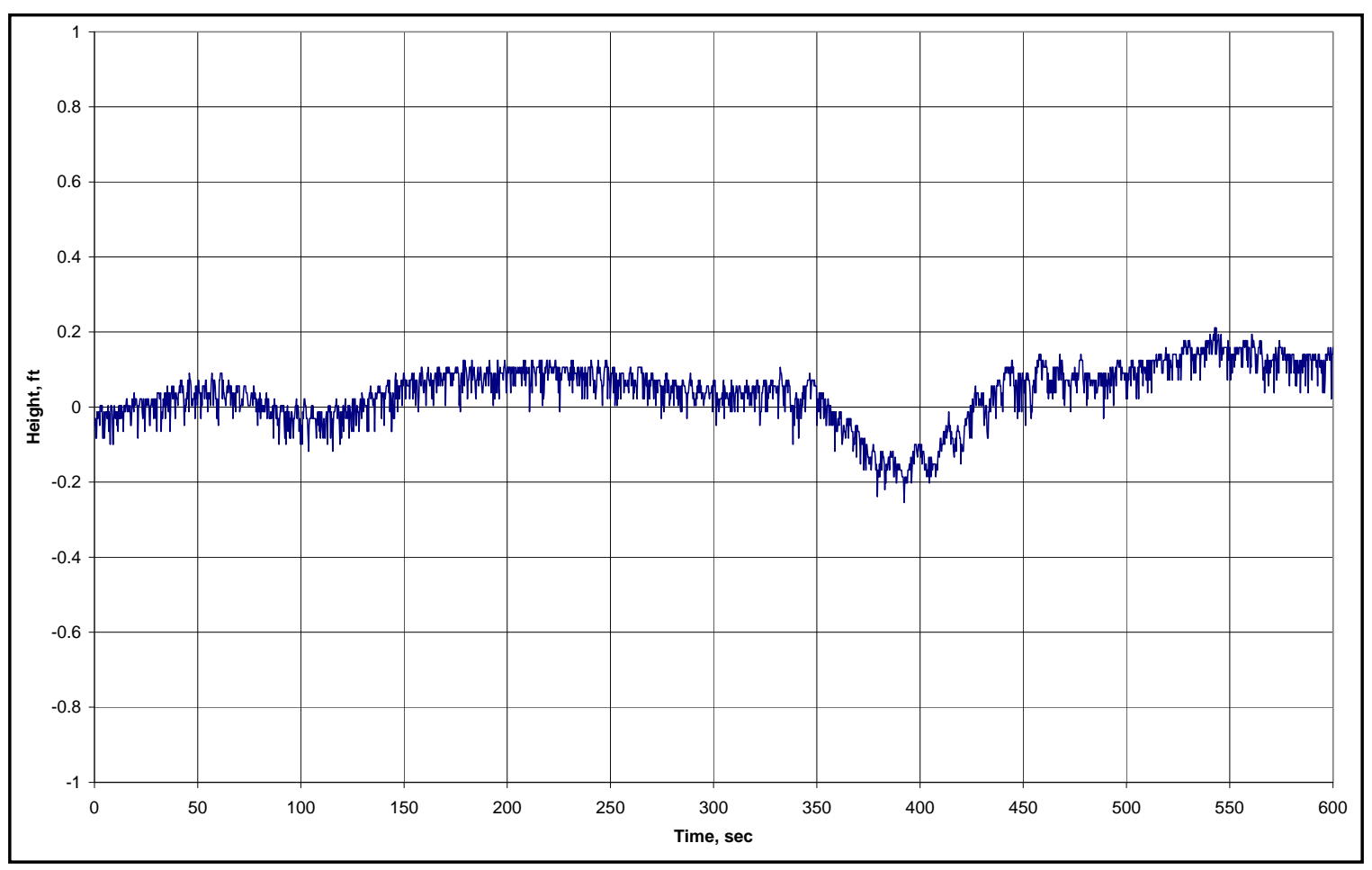

Figure A19. MSC Christina, outbound, time 0 = 2000 EDT, 17 Sep 2005. 


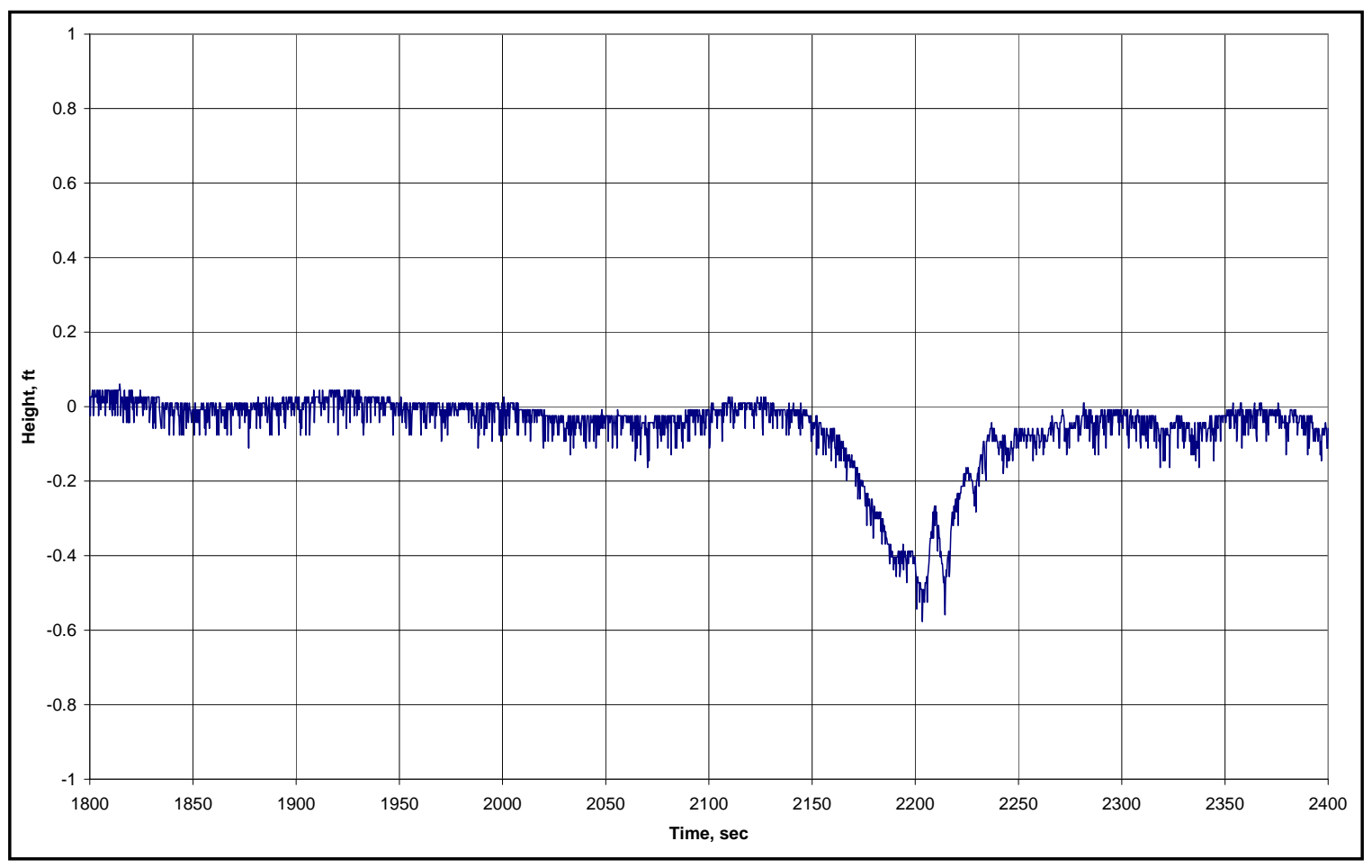

Figure A20. Zim Israel, outbound, time 0 = 2100 EDT, 17 Sep 2005.

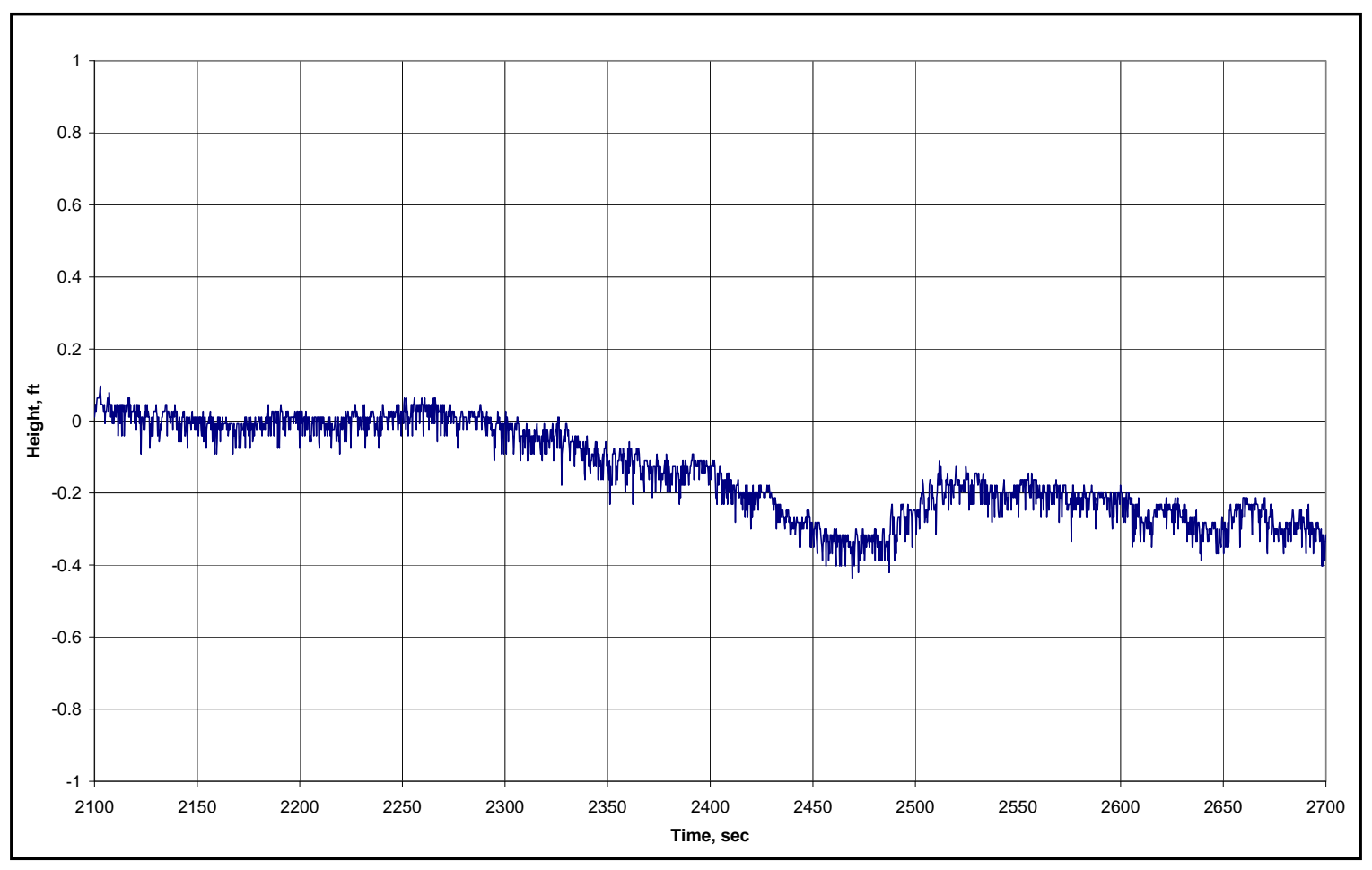

Figure A21. MSC Eleni, outbound, time 0 = 0000 EDT, 18 Sep 2005. 
ERDC/CHL TR-07-7

64

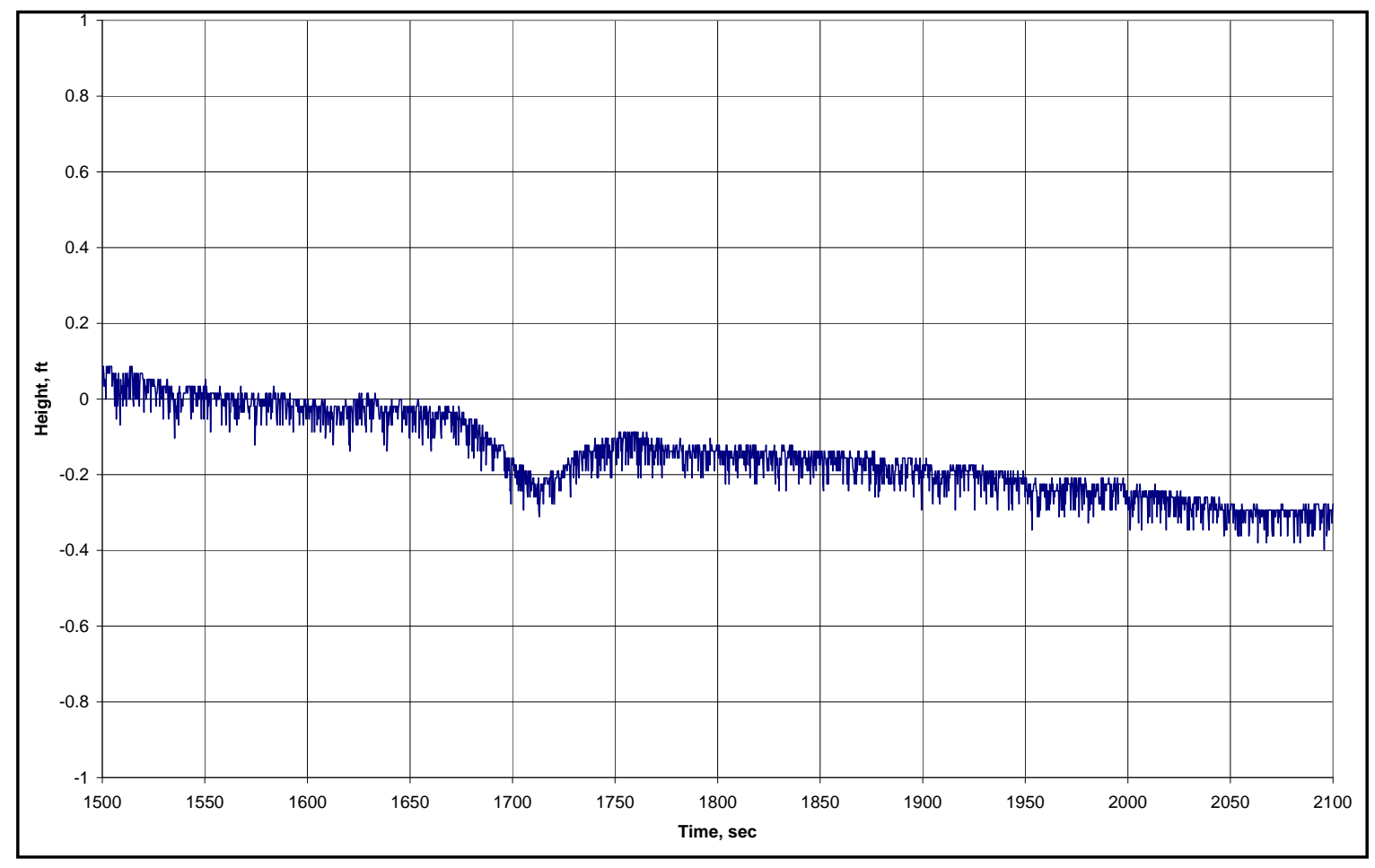

Figure A22. Midnight Sun, outbound, time 0 = 1300 EDT, 18 Sep 2005.

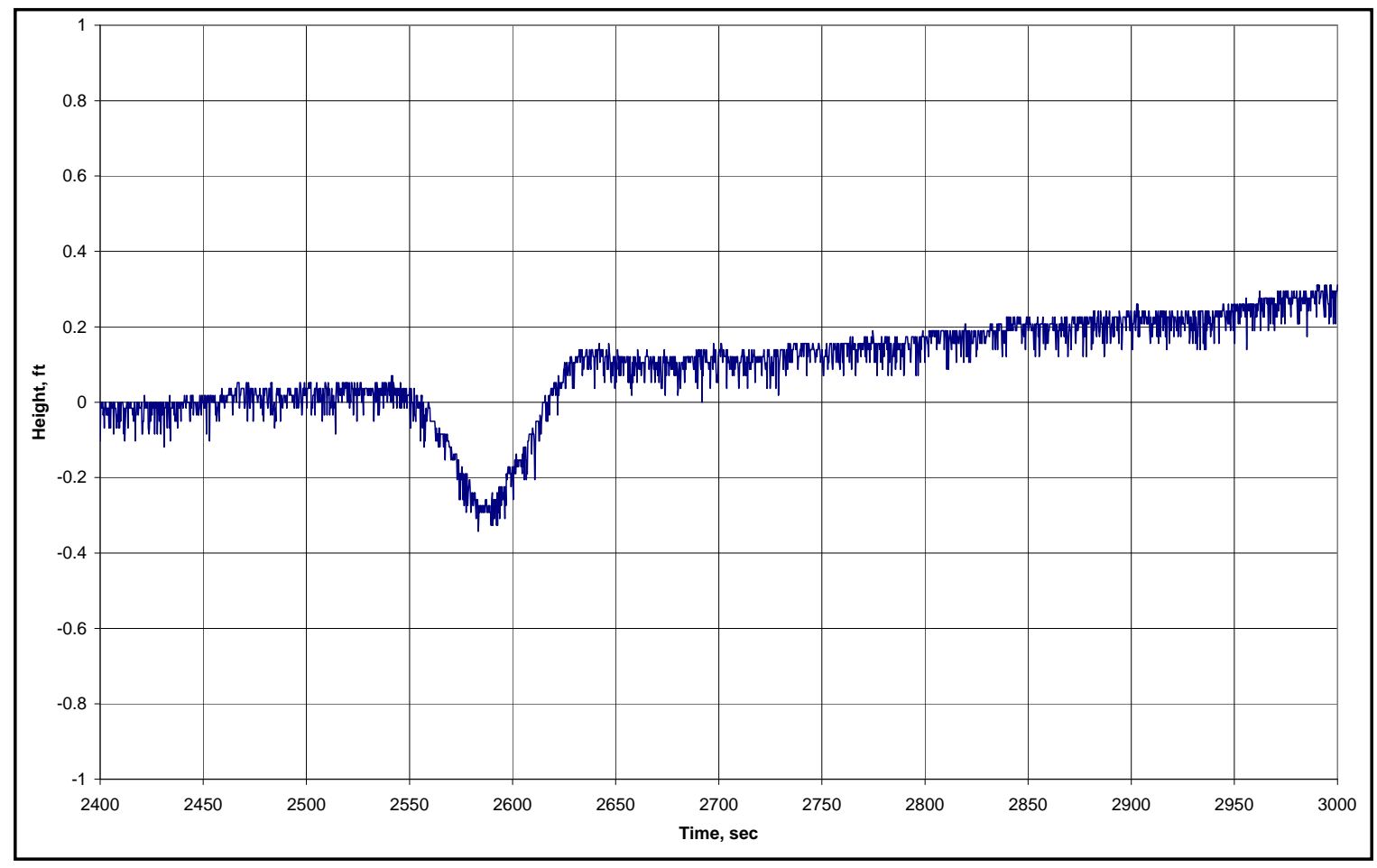

Figure A23. Rim Iberia, outbound, time 0 = 1900 EDT, 18 Sep 2005. 


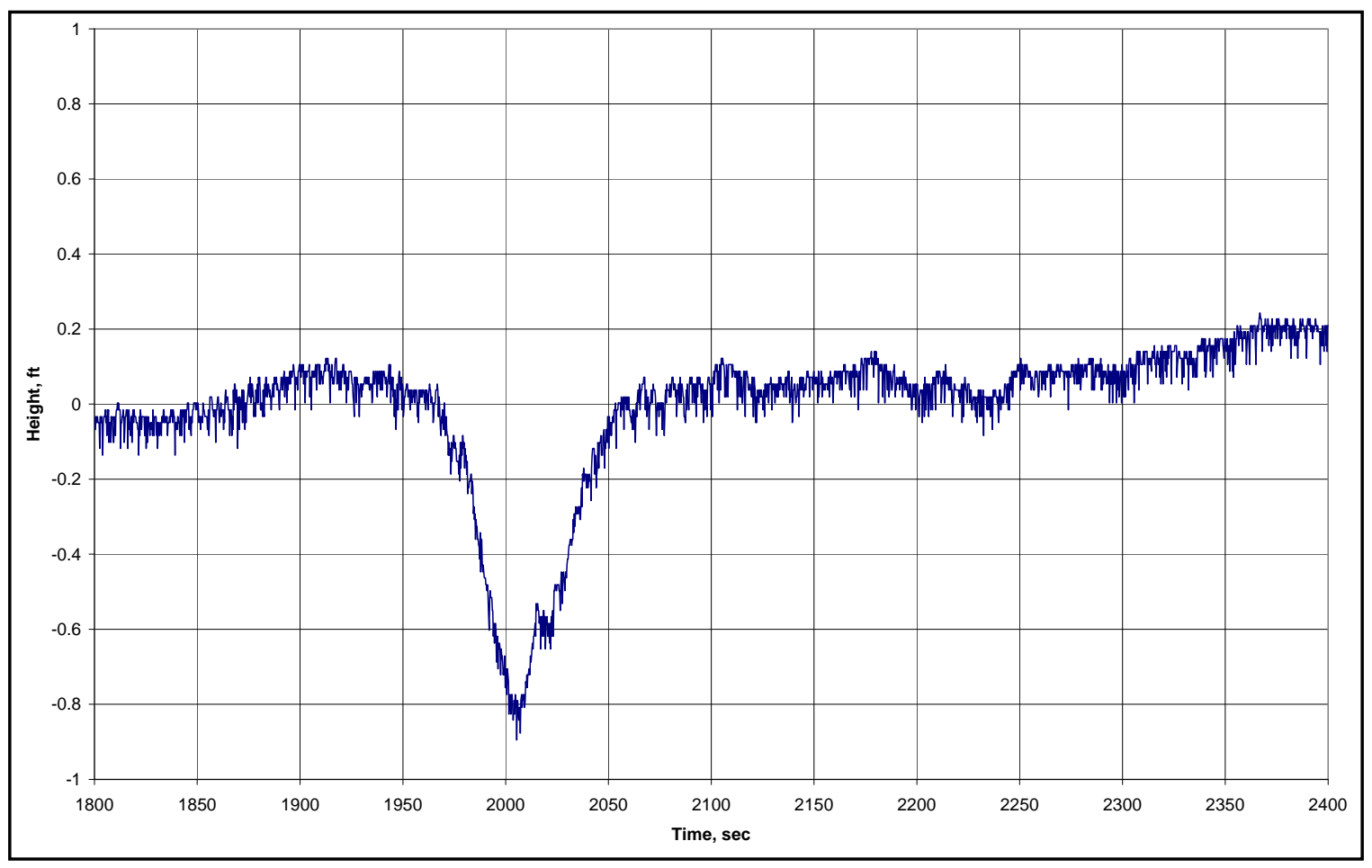

Figure A24. Alyona, outbound, time 0 = 2000 EDT, 18 Sep 2005.

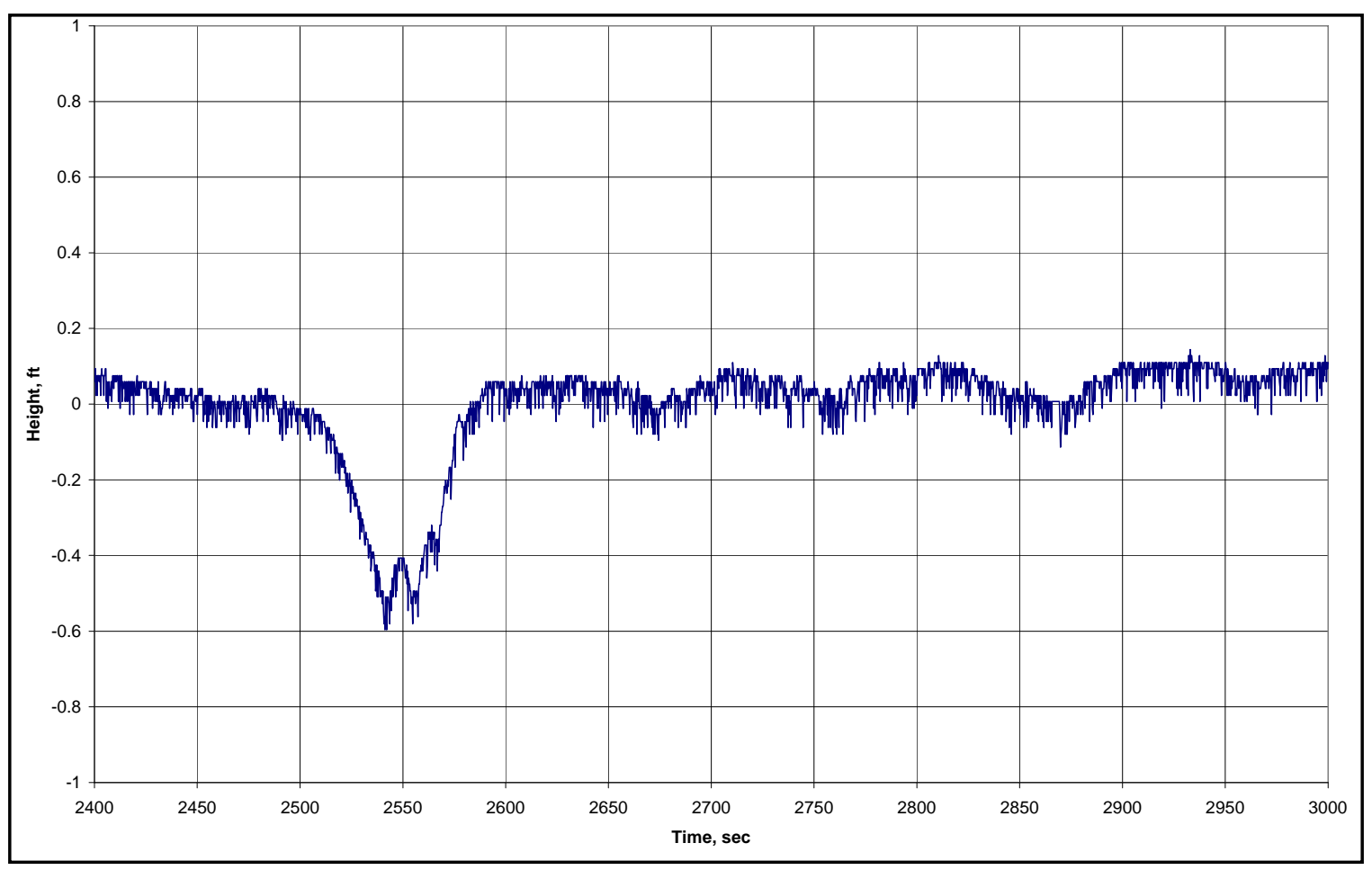

Figure A25. Darya Rani, outbound, time 0 = 2100 EDT, 18 Sep 2005. 


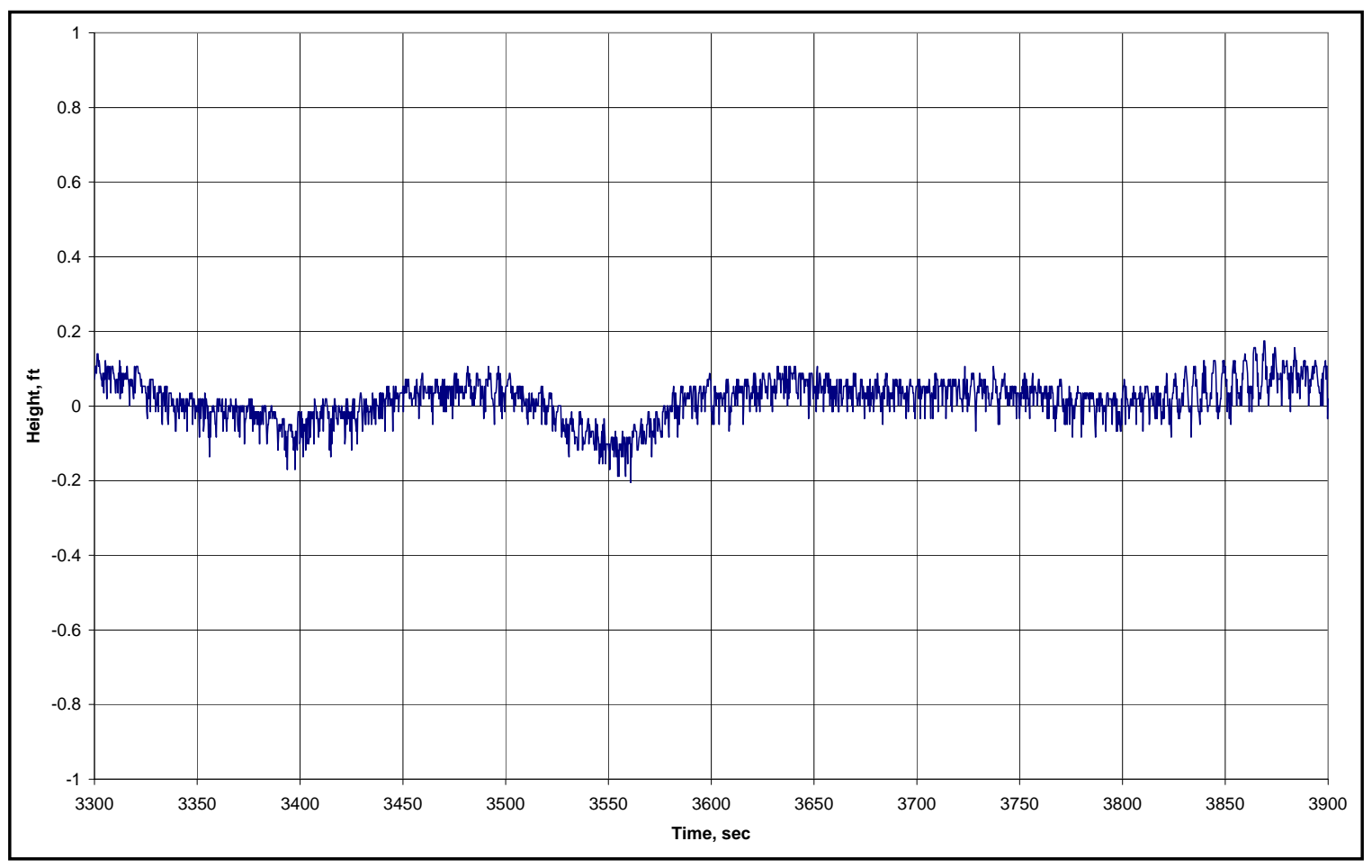

Figure A26. Sumida, outbound, time 0 = 2100 EDT, 18 Sep 2005.

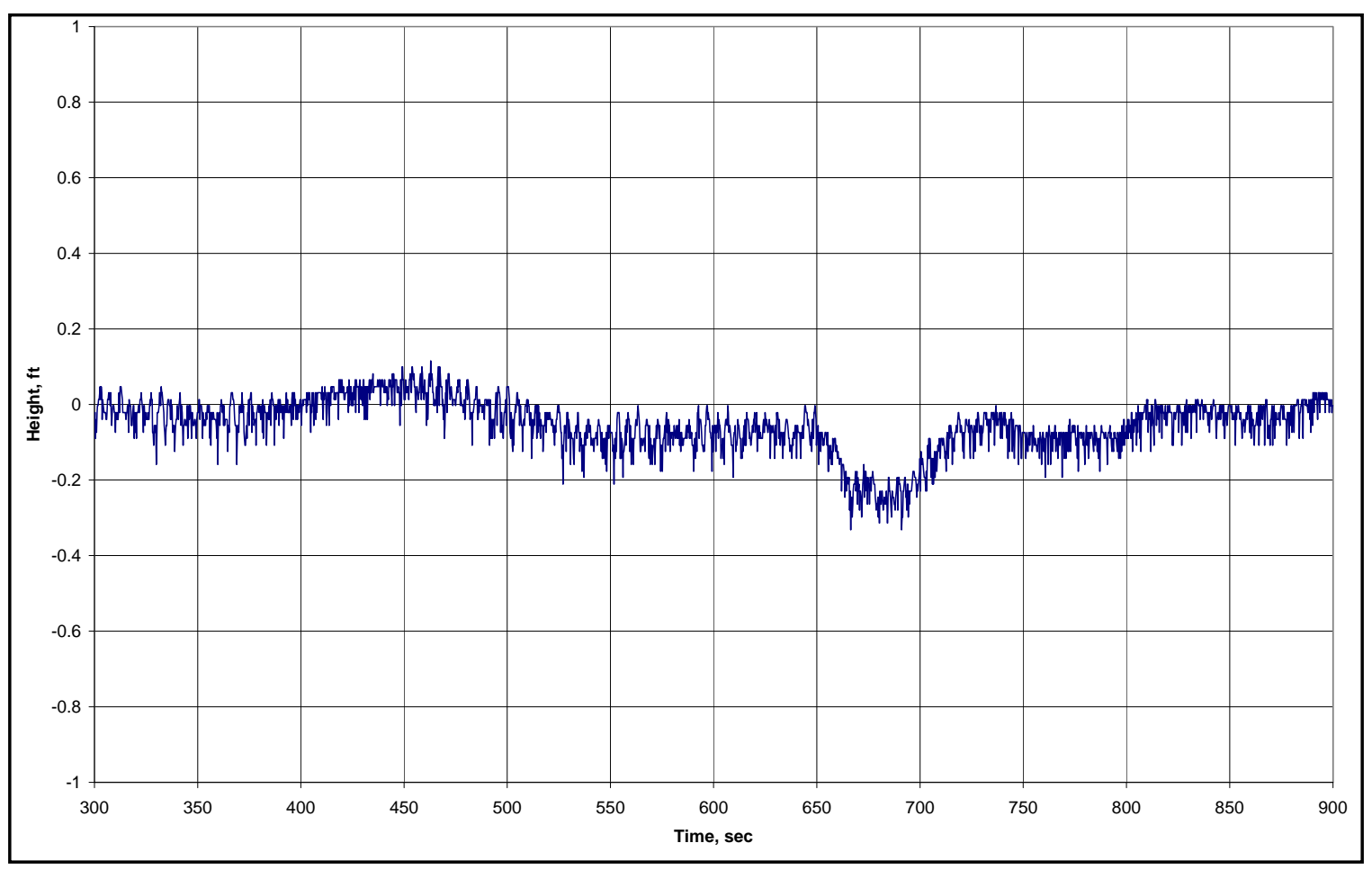

Figure A27. Al Mariyah, outbound, time 0 = 2200 EDT, 18 Sep 2005. 


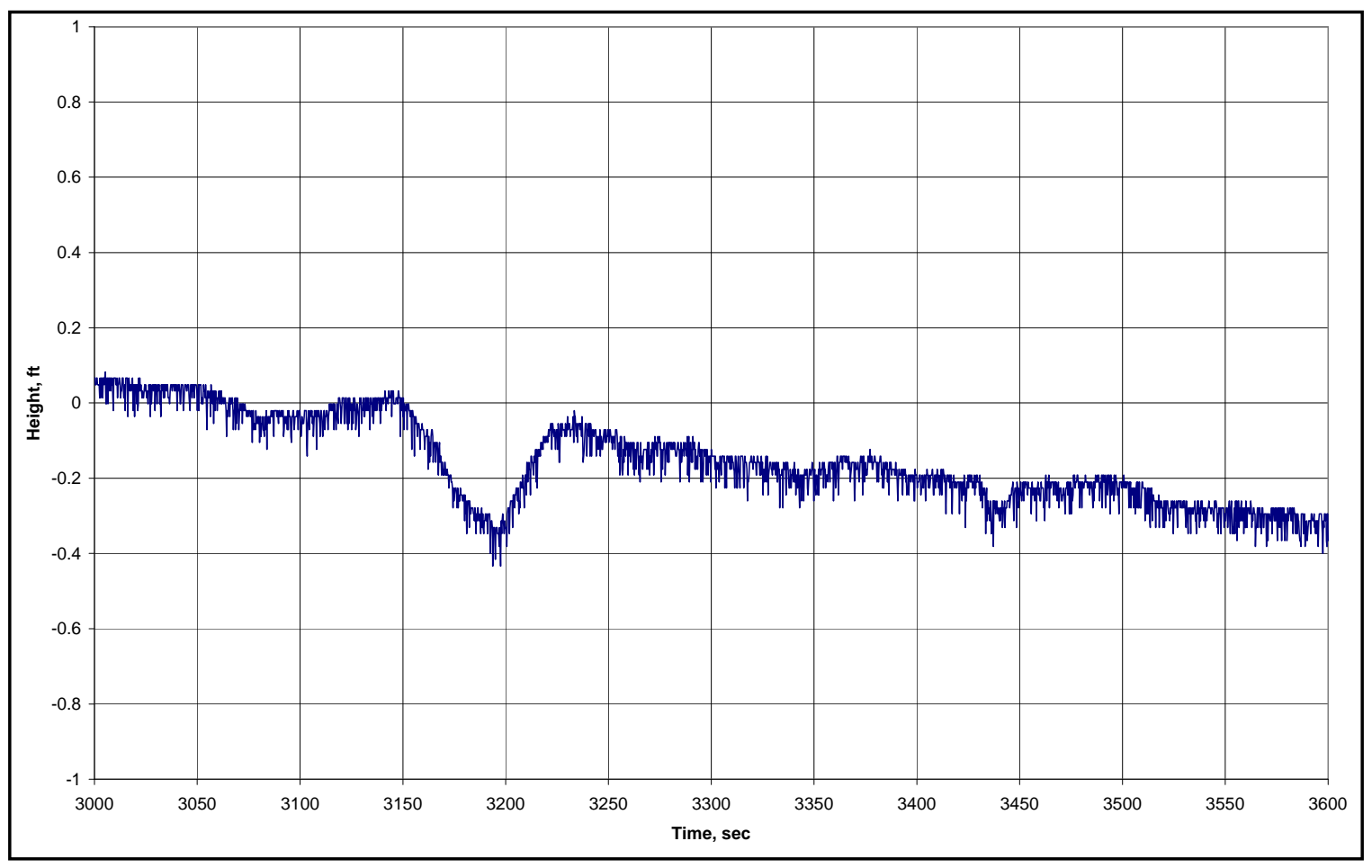

Figure A28. MSC Elena, outbound, time 0 = 0200 EDT, 19 Sep 2005.

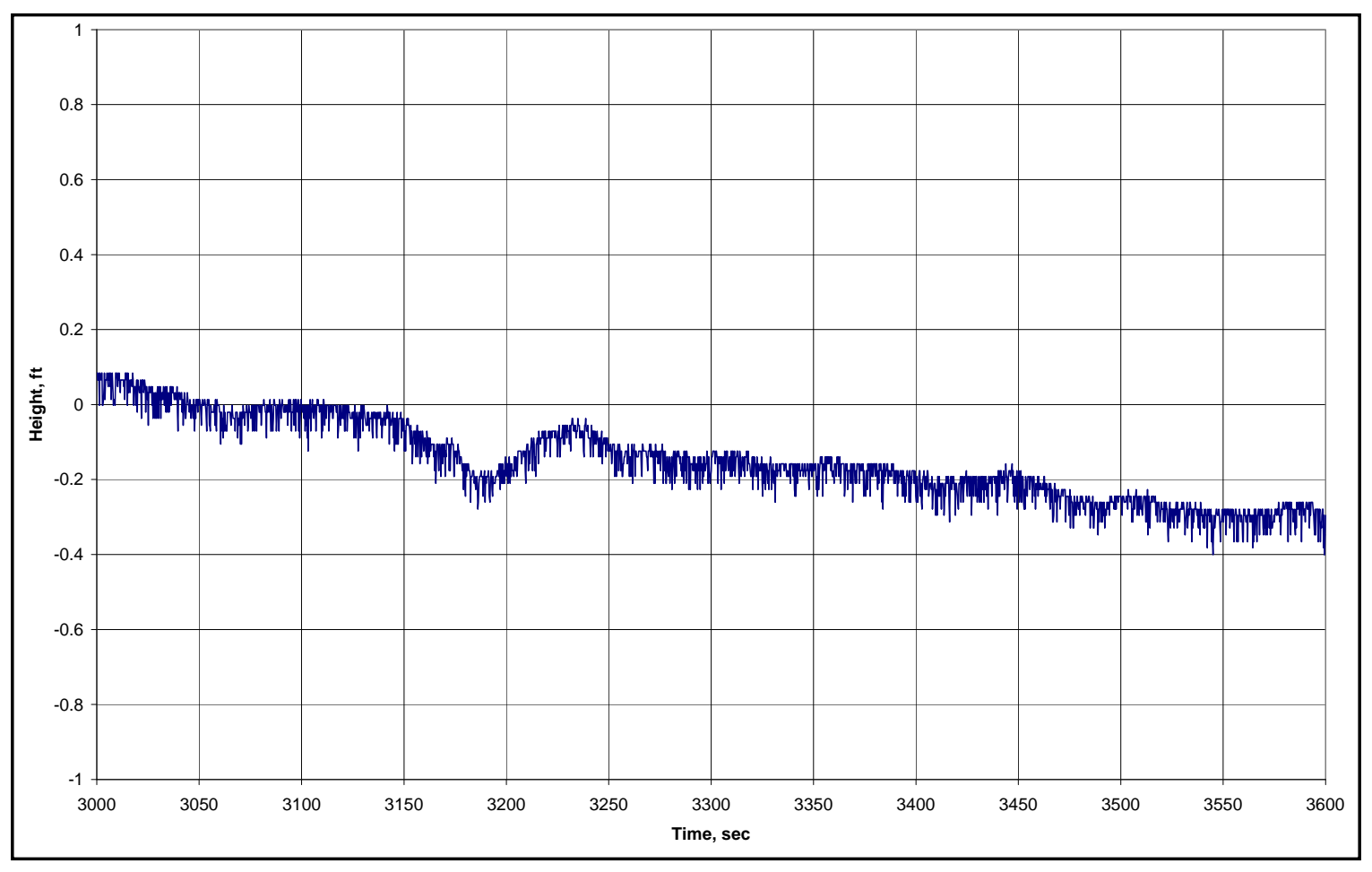

Figure A29. Condor, outbound, time $0=1300$ EDT, 19 Sep 2005. 


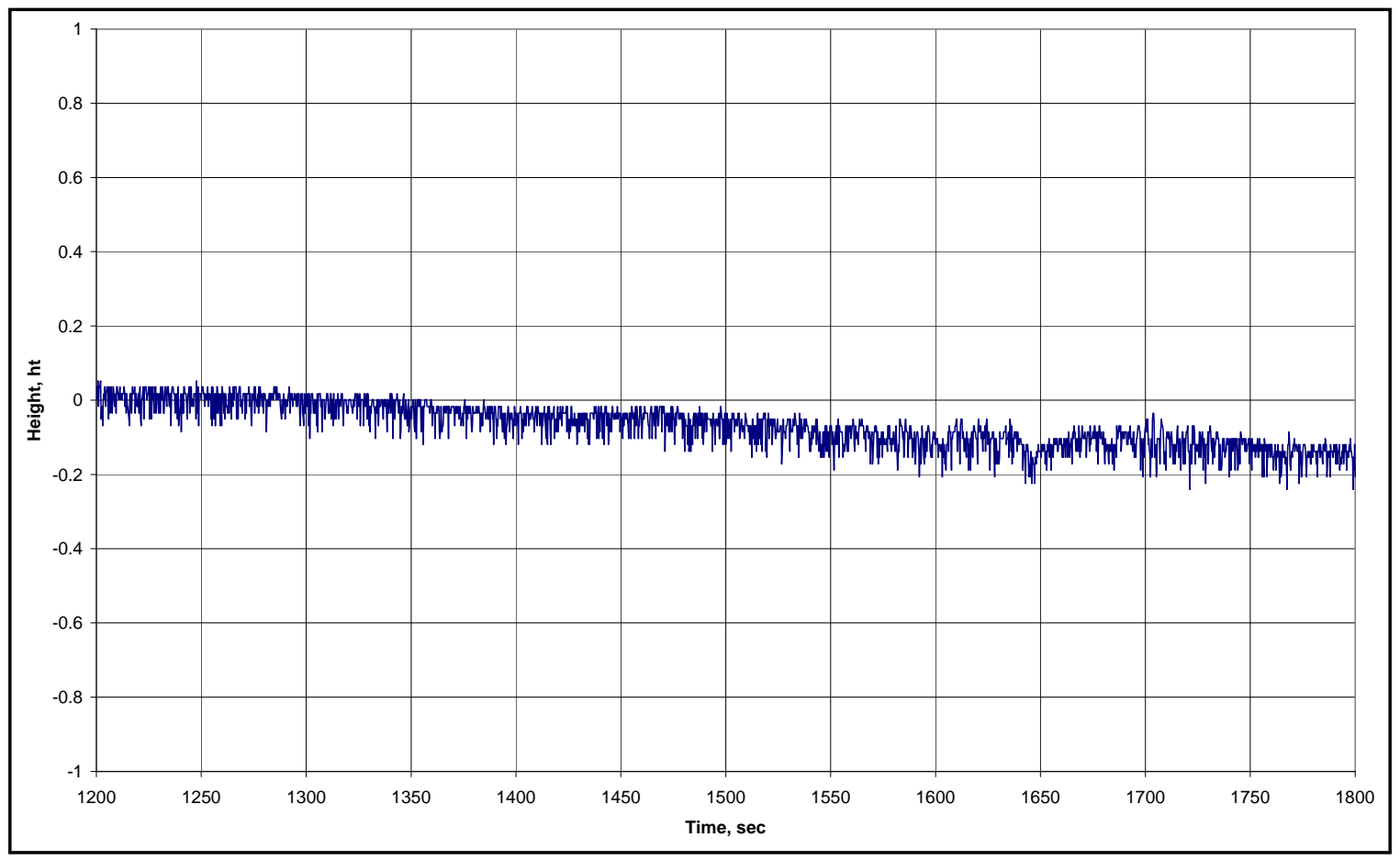

Figure A30. Emmanuelle Tomassos, outbound, time 0 = 1400 EDT, 19 Sep 2005.

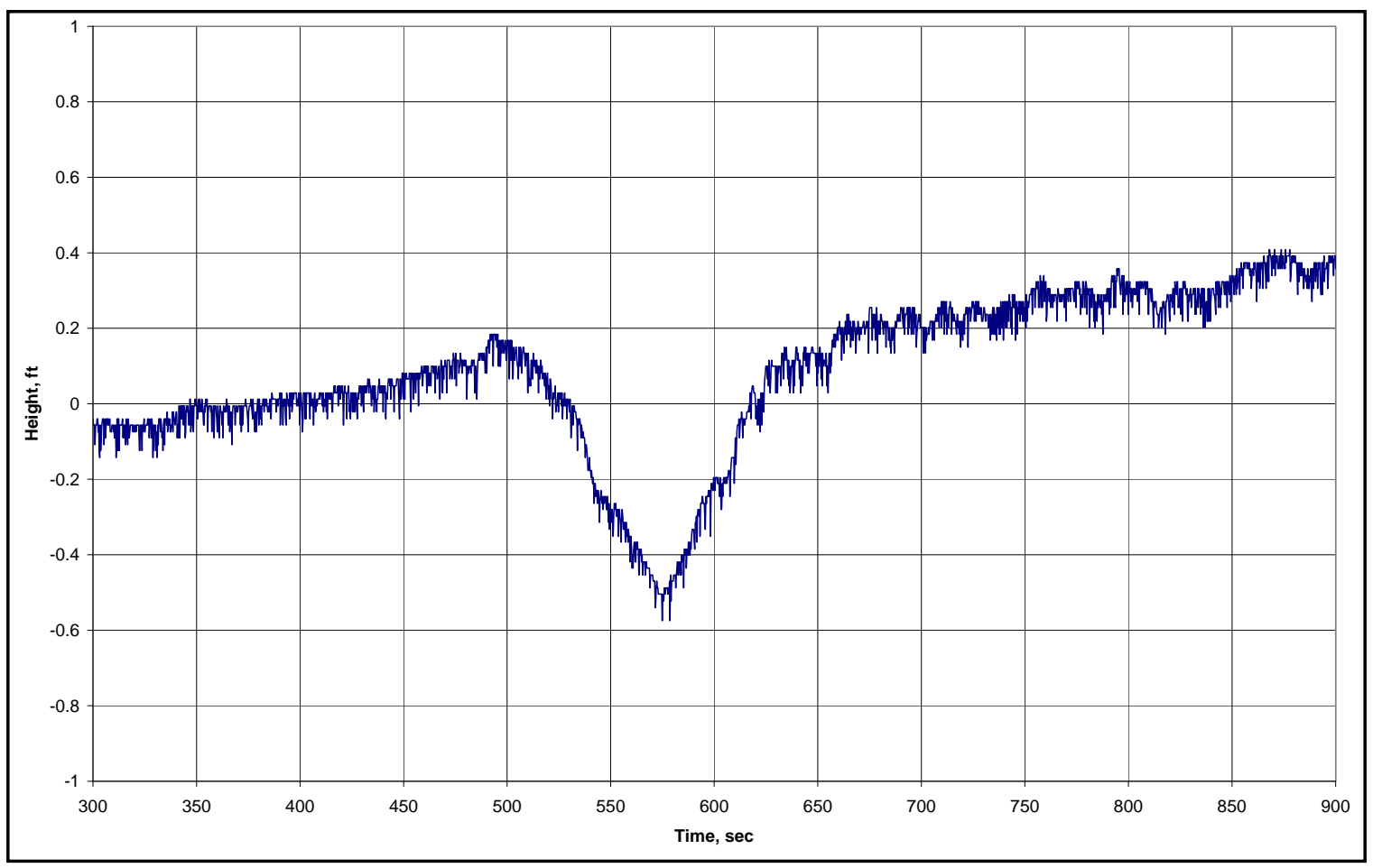

Figure A31. Victoria Bridge, outbound, time 0 = 1900 EDT, 19 Sep 2005. 


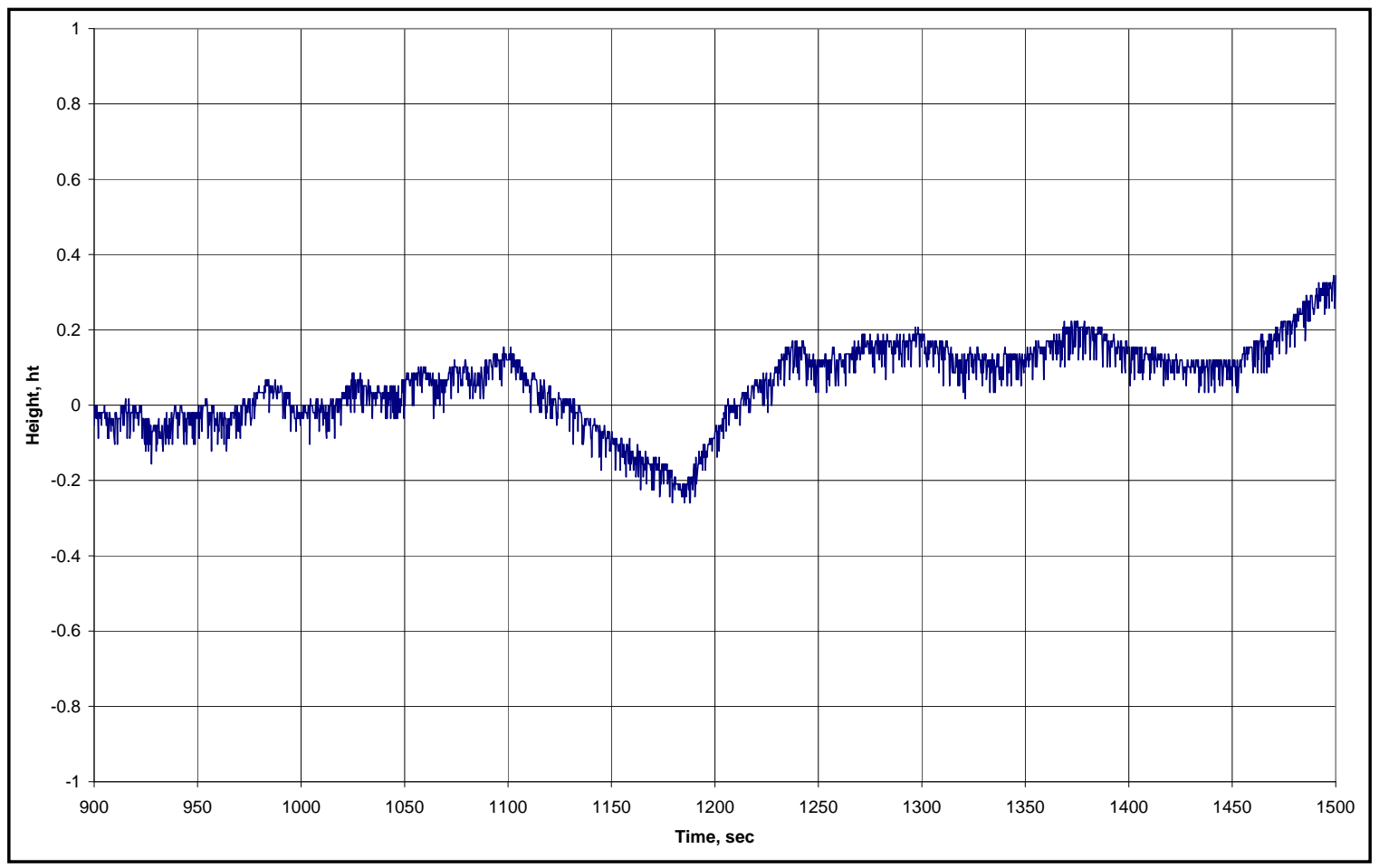

Figure A32. Hanjin Wilmington, outbound, time 0 = 2000 EDT, 19 Sep 2005.

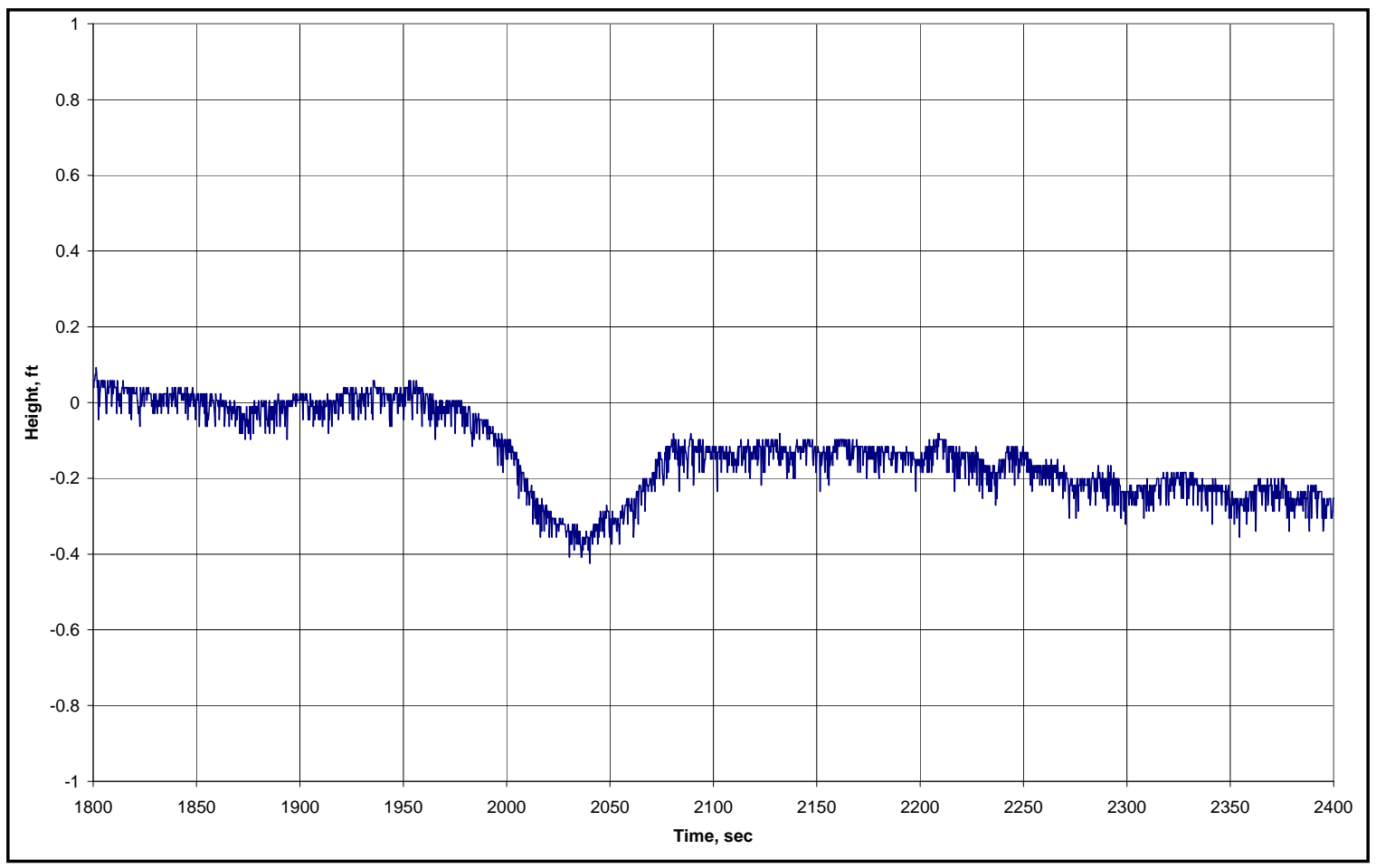

Figure A33. Essen Express, outbound, time 0 = 0200 EDT, 20 Sep 2005. 


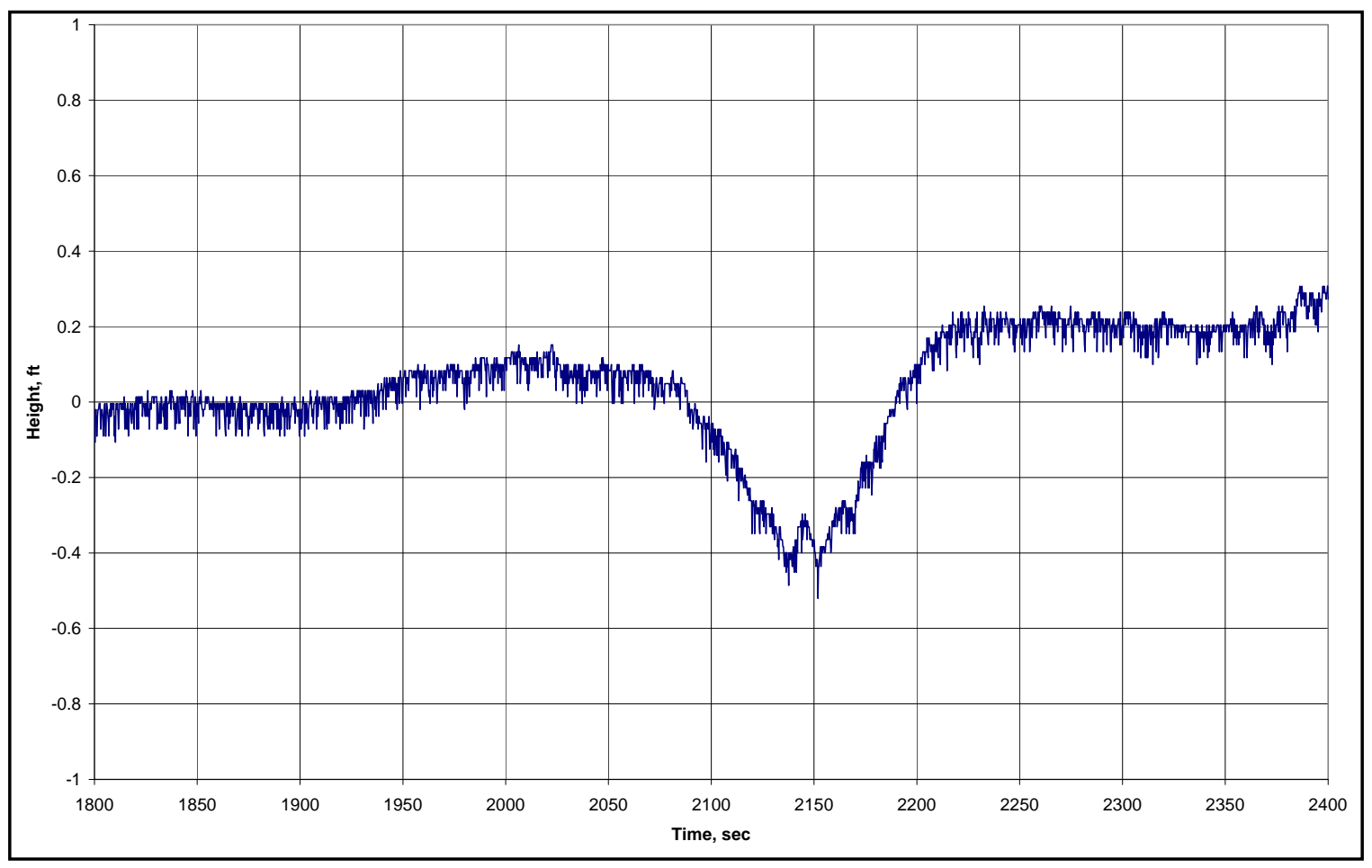

Figure A34. Mol Velocity, outbound, time 0 = 0800 EDT, 20 Sep 2005.

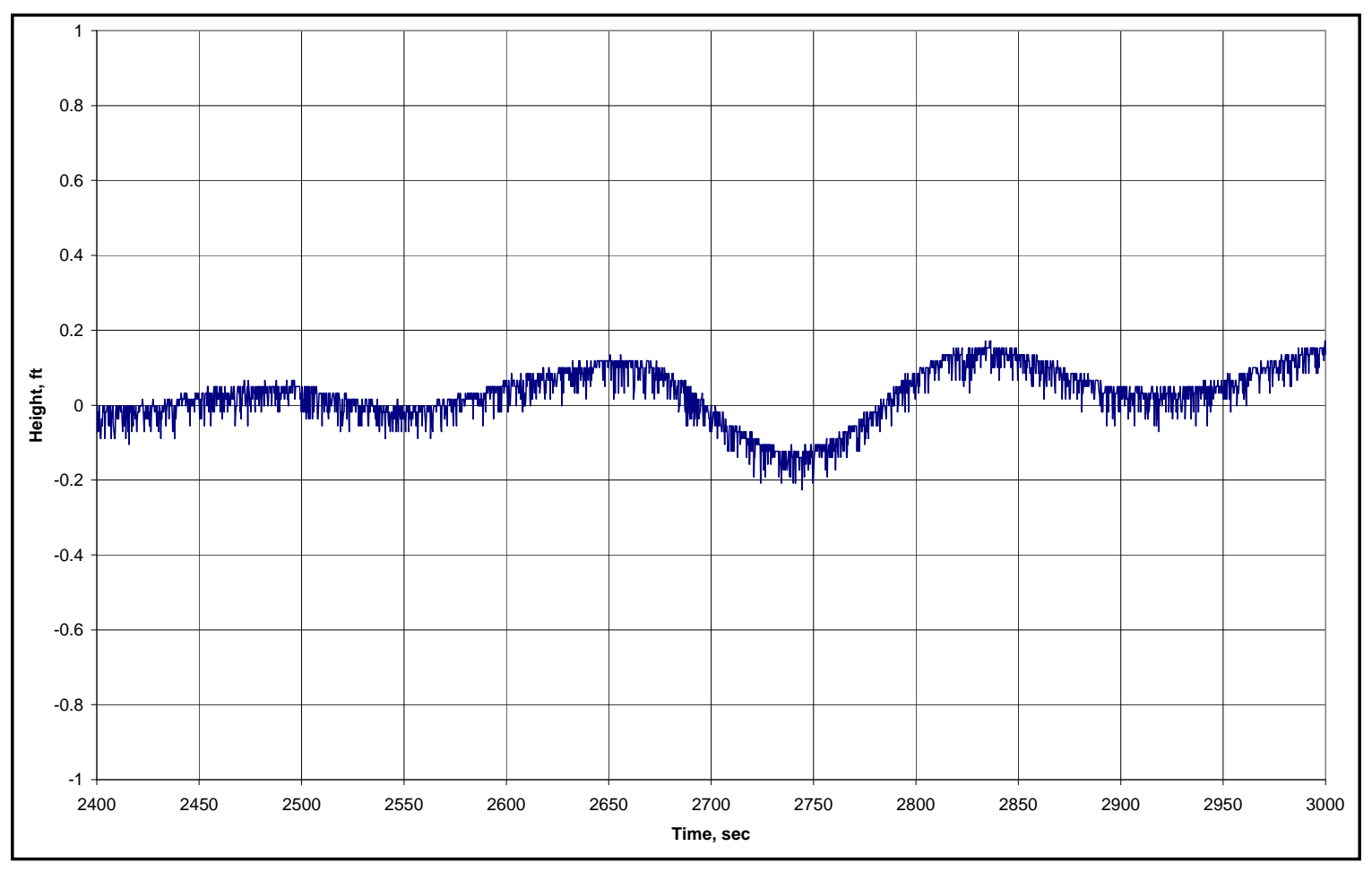

Figure A35. Kavo Alexandros II, outbound, time 0 = 0900 CDT, 20 Sep 2005. 
ERDC/CHL TR-07-7

71

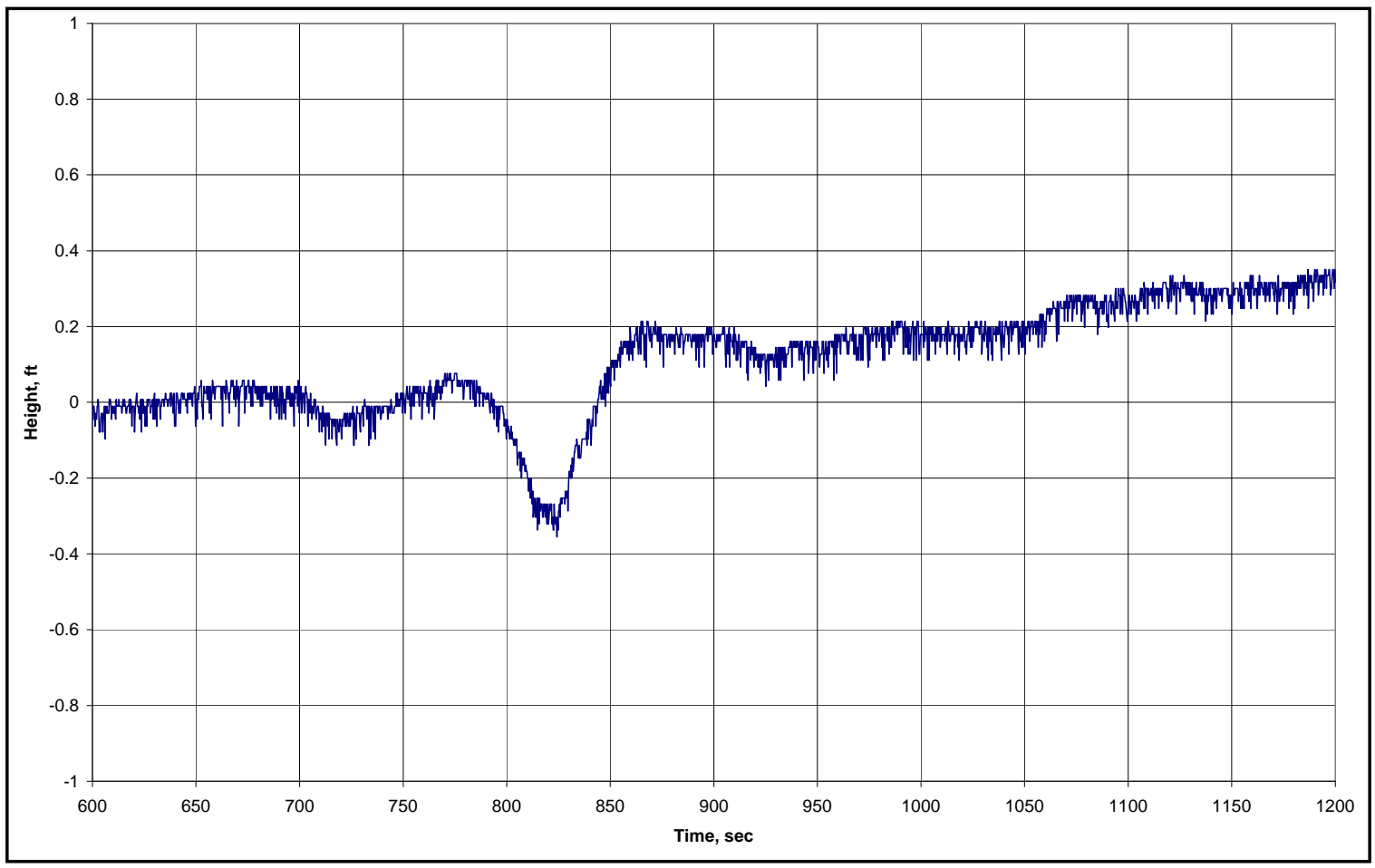

Figure A36. Angel Accord, outbound, time 0 = 1900 EDT, 20 Sep 2005.

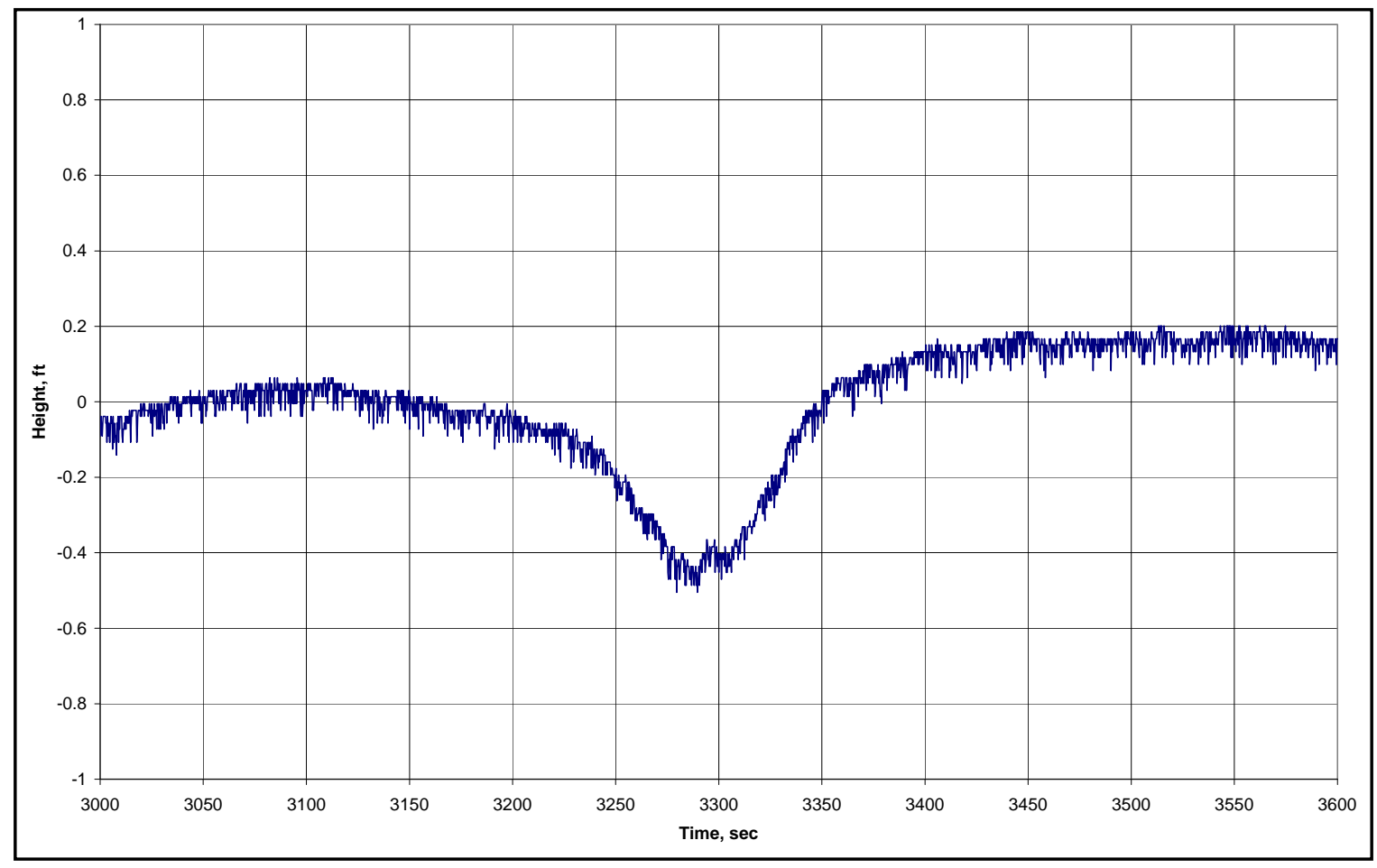

Figure A37. Stuttgart Express, outbound, time $0=2100$ EDT, 20 Sep 2005. 


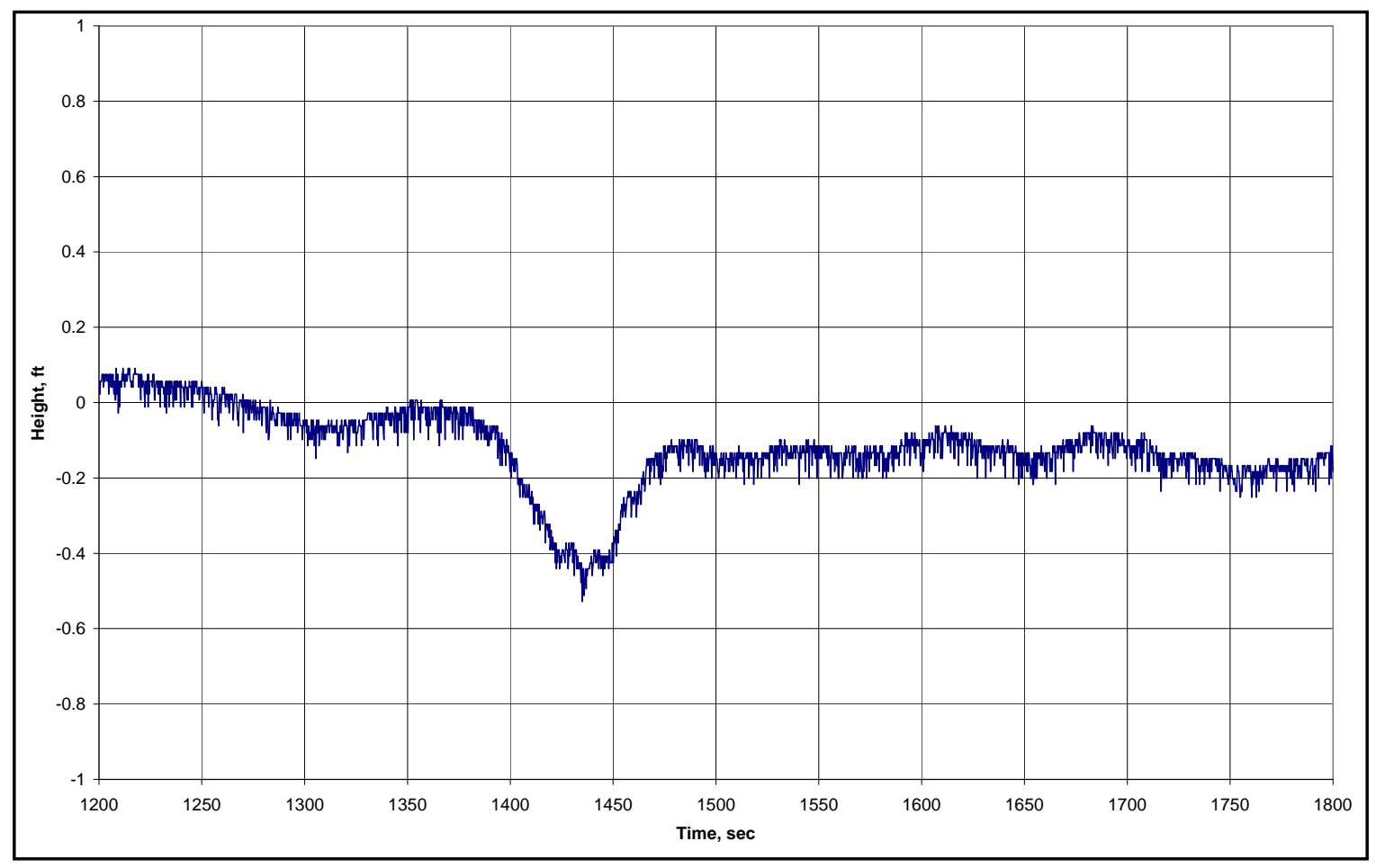

Figure A38. Jervis Bay, outbound, time 0 = 0100 EDT, 21 Sep 2005. 


\section{Appendix B: Ship Wave Height at Confined Disposal Facility, Wave Gauge CH3}

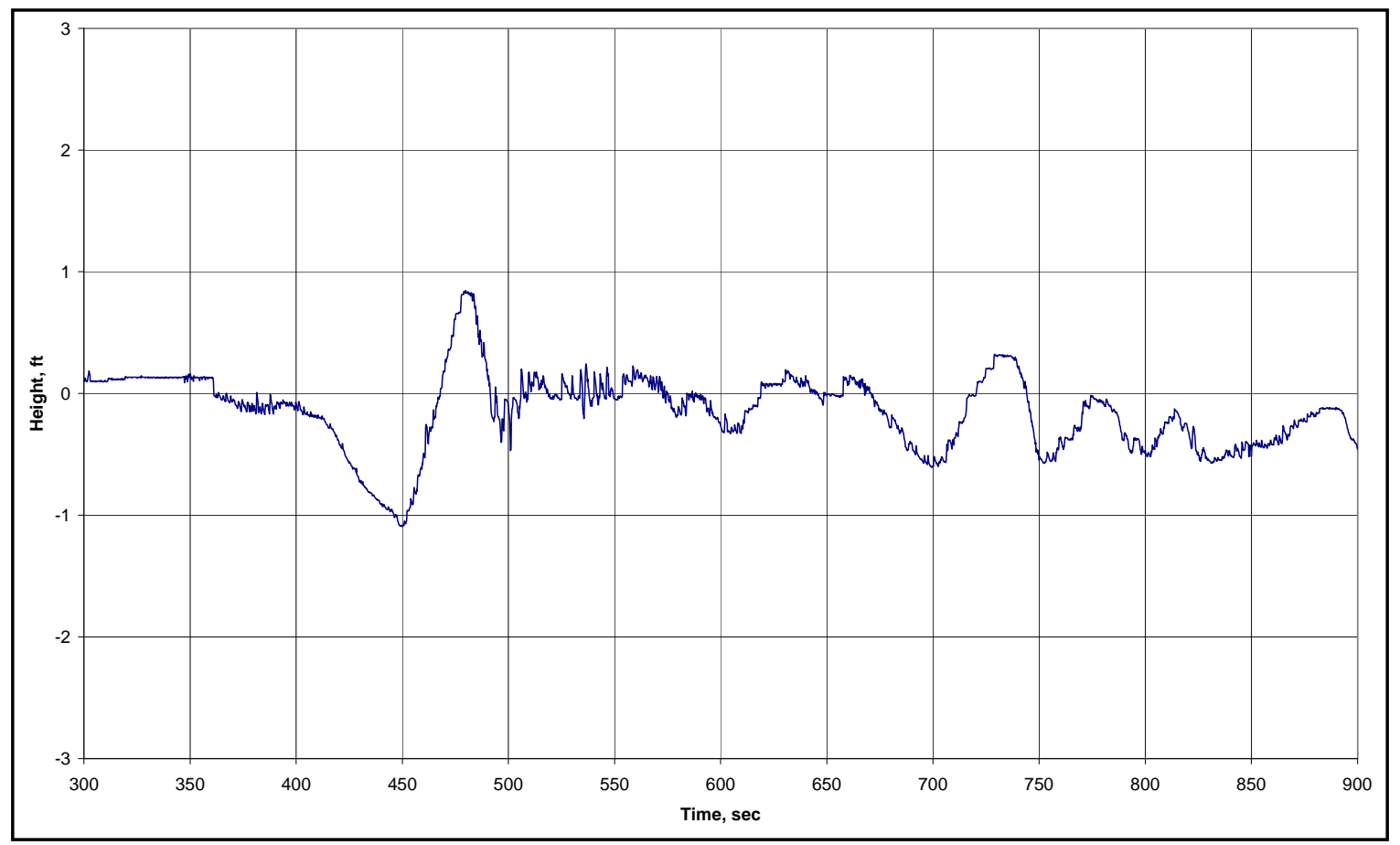

Figure B1. Emmanuel Tomassos, inbound, time 0 = 1400 EDT, 18 Sep 2005. 


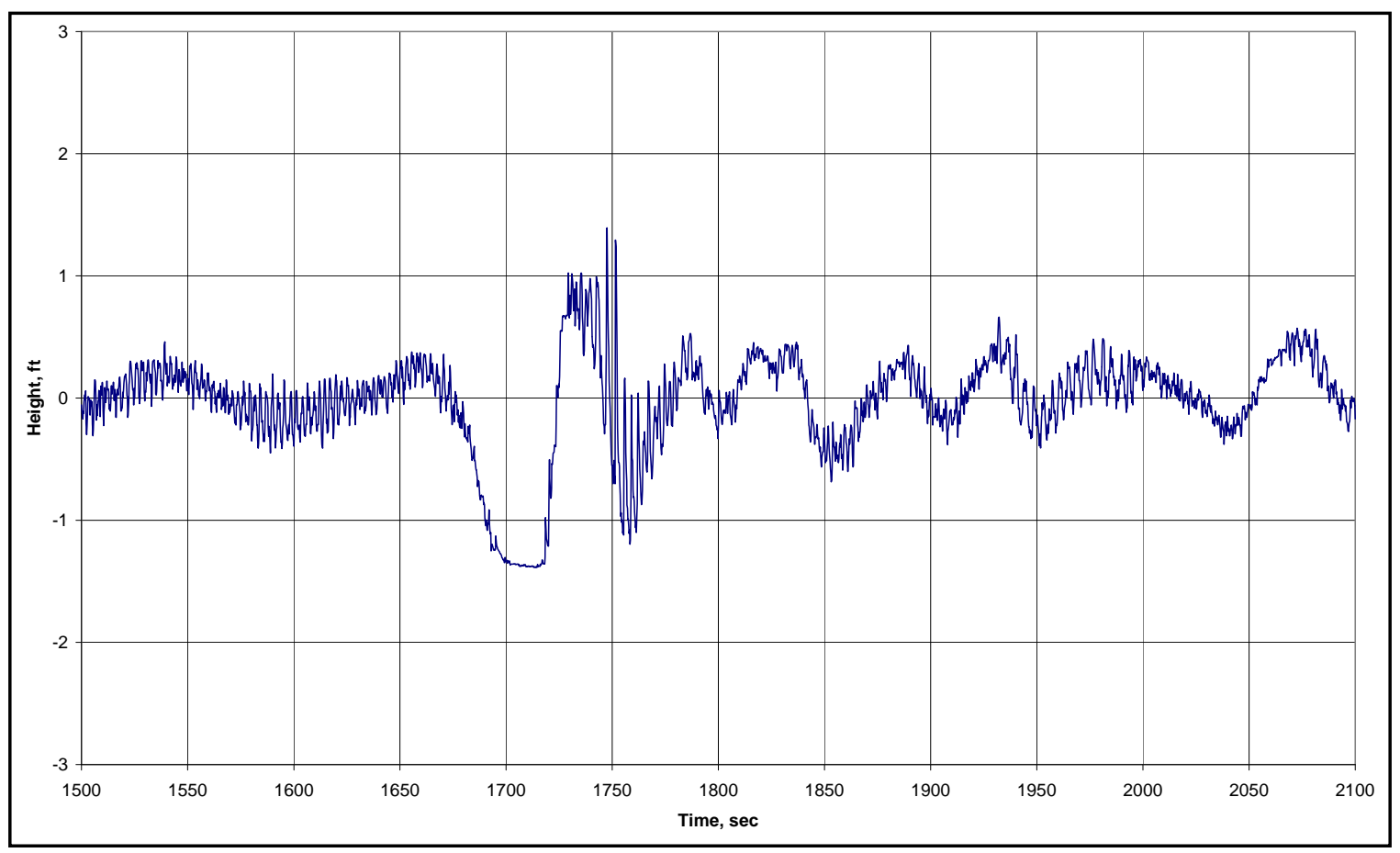

Figure B2. Hanjin Wilmington, inbound, time 0 = 1600 EDT, 18 Sep 2005.

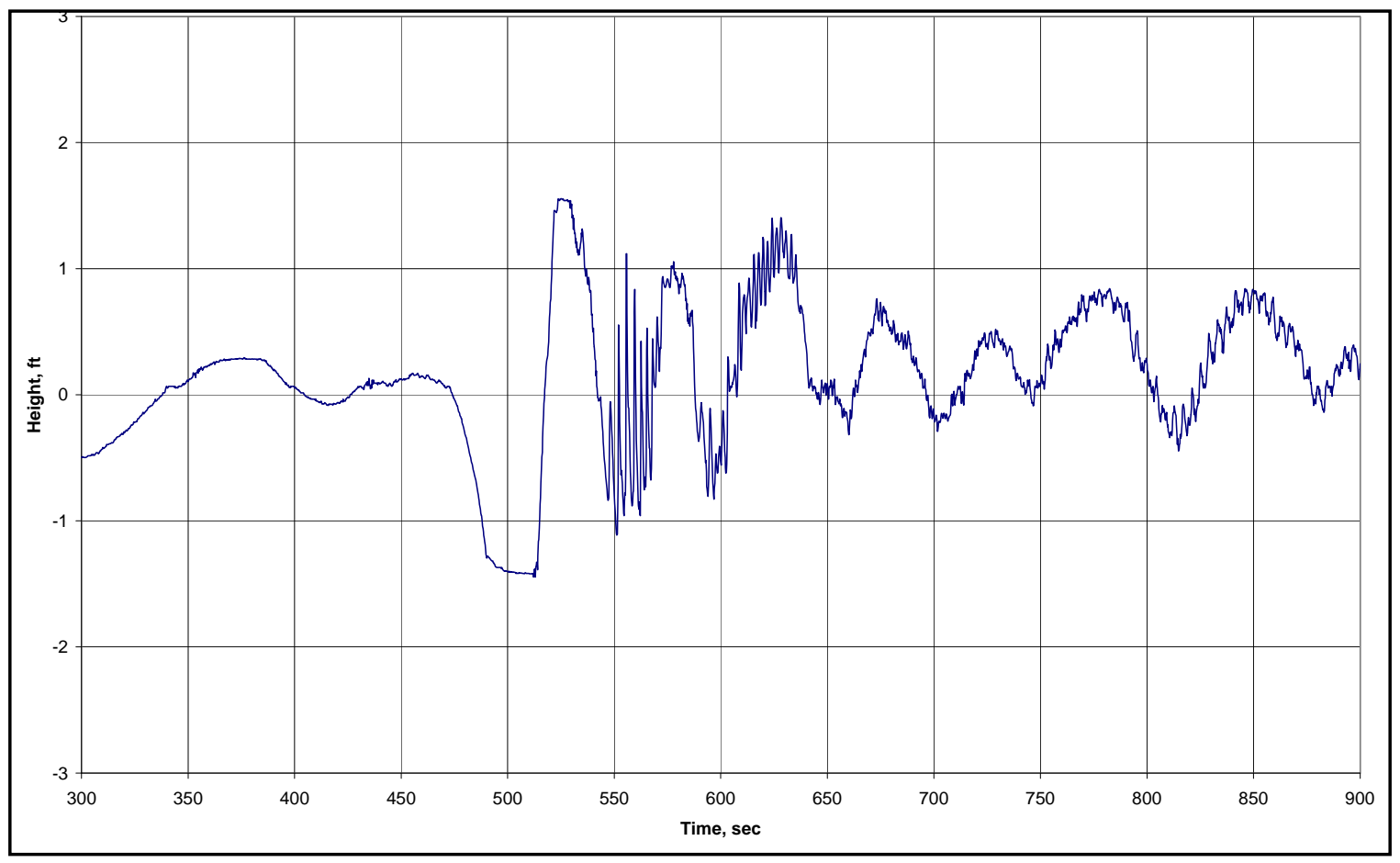

Figure B3. Essen Express, inbound, time 0 = 0500, 19 Sep 2005. 


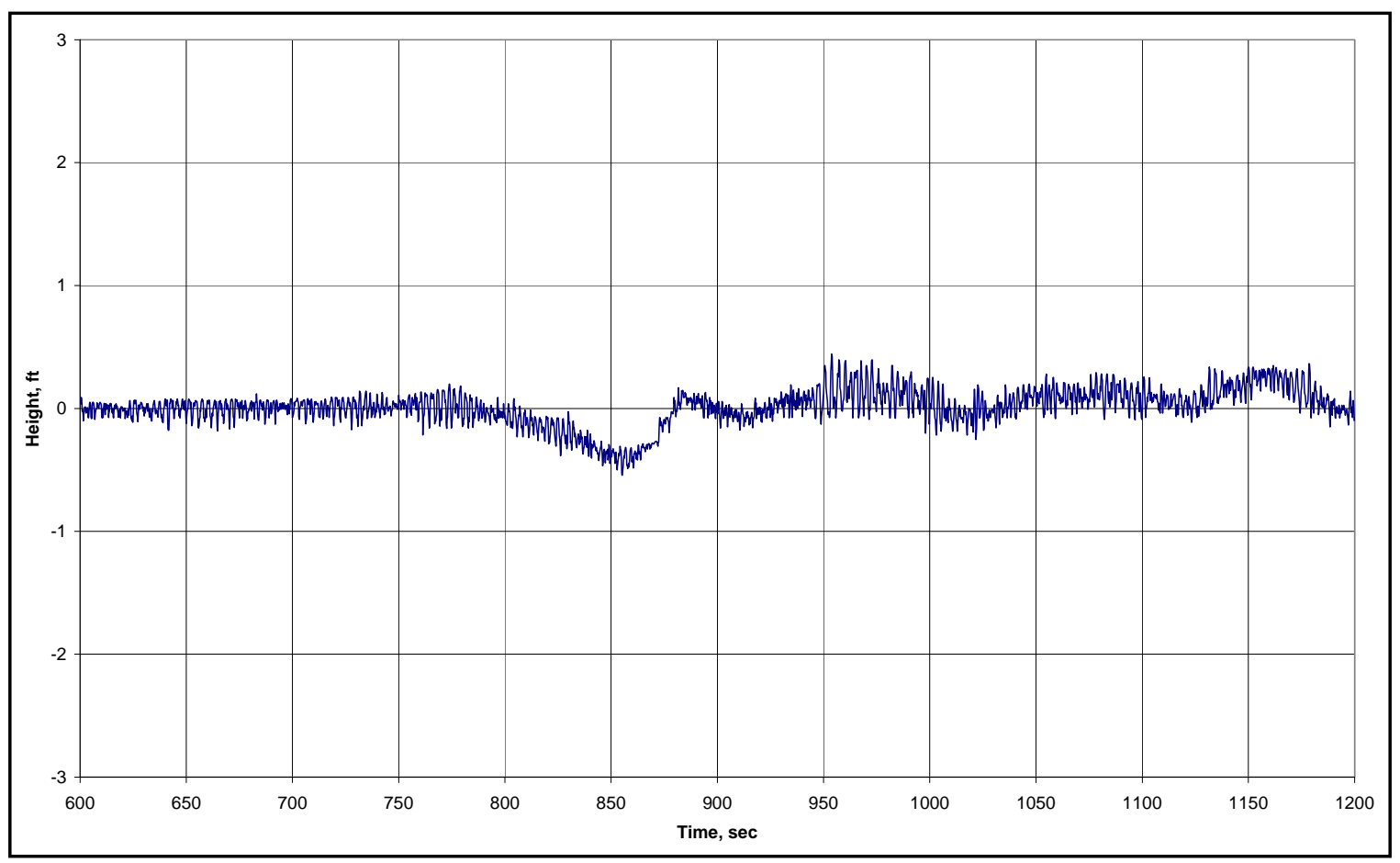

Figure B4. Angel Accord, inbound, time 0 = 1700 EDT, 19 Sep 2005.

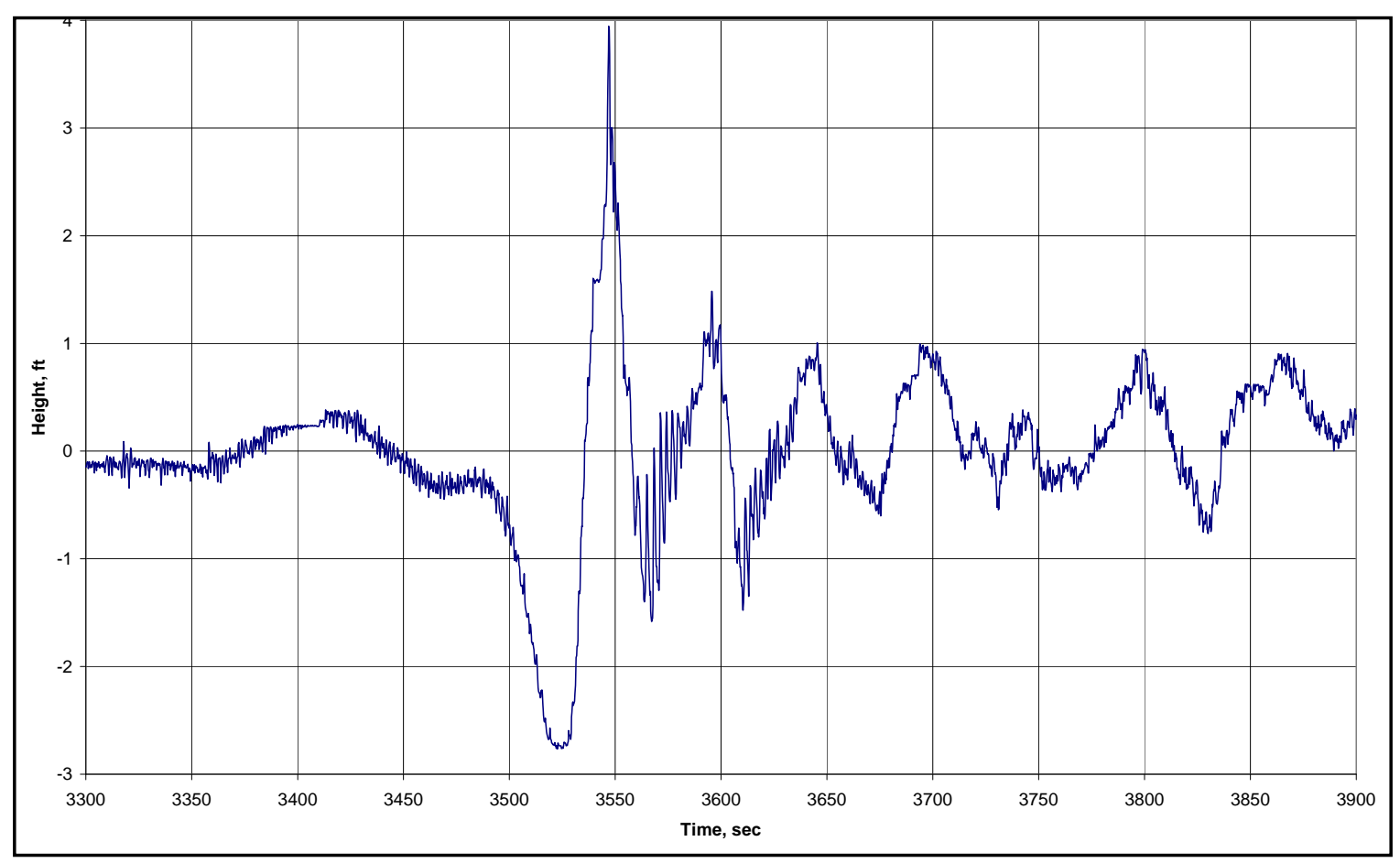

Figure B5. Mol Velocity, inbound, time 0 = 1700 EDT, 19 Sep 2005. 


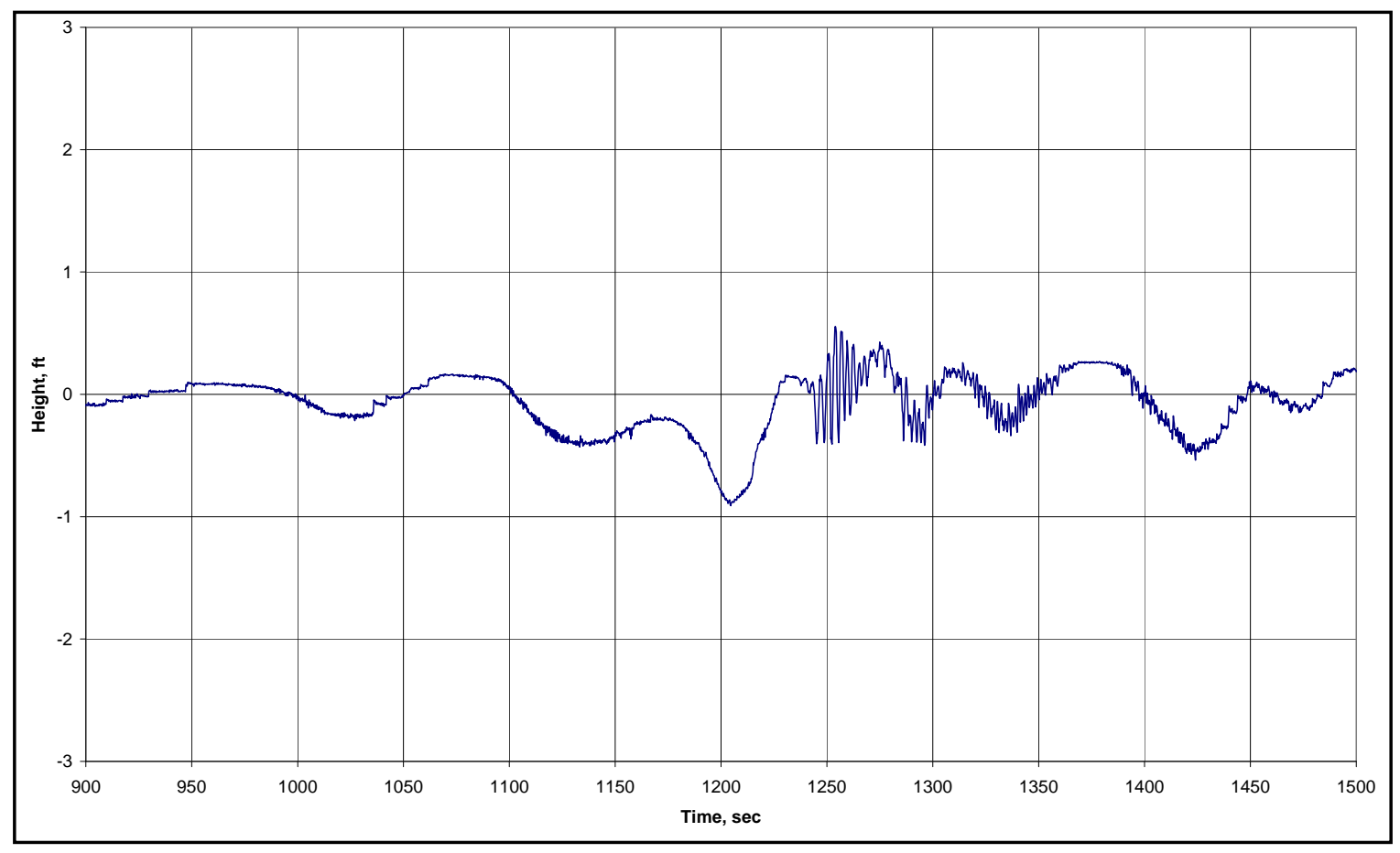

Figure B6. Stuttgart Express, inbound, time 0 = 2300 EDT, 19 Sep 2005.

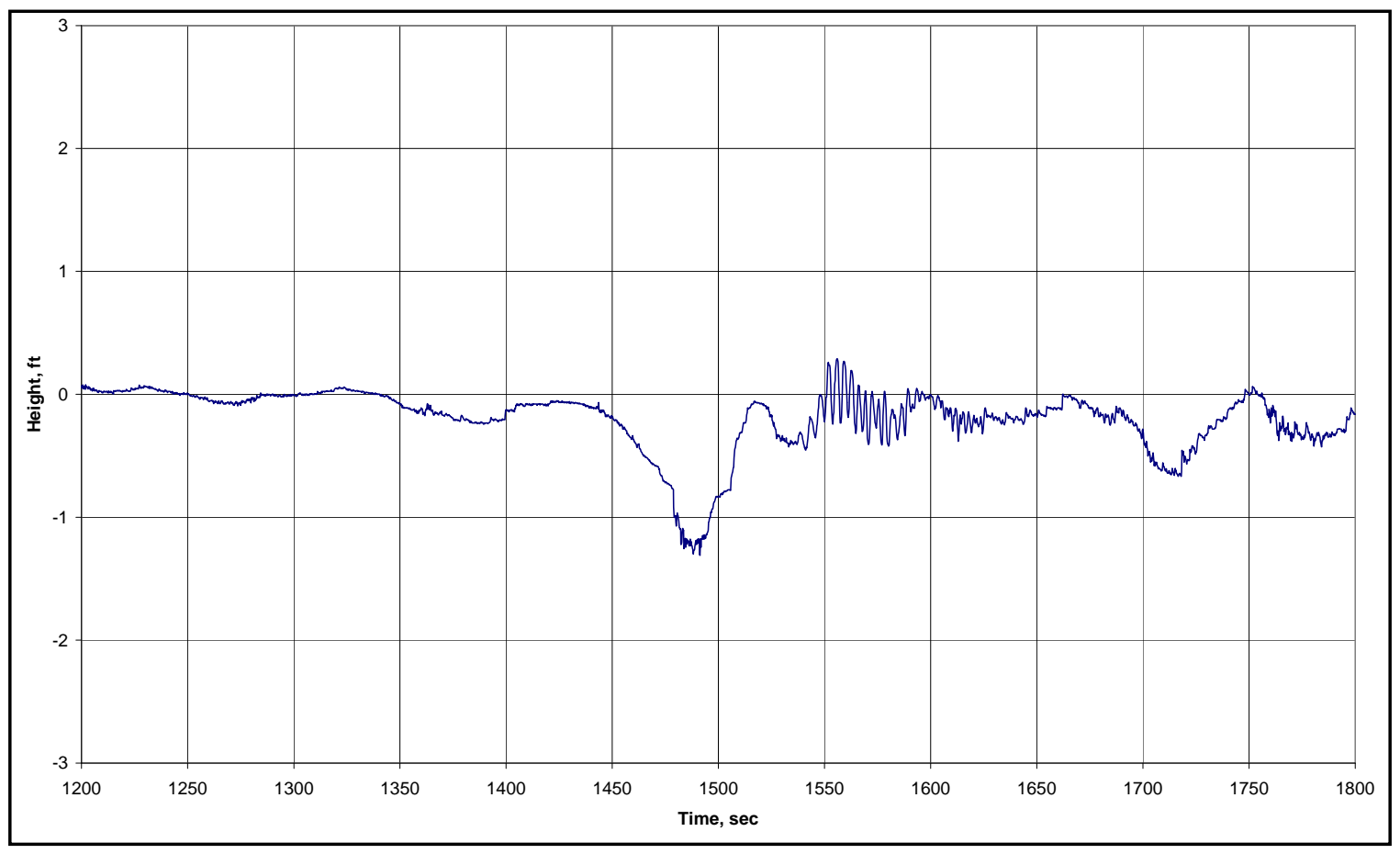

Figure B7. Ville de Taurus, inbound, time 0 = 0200 EDT, 21 Sep 2005. 


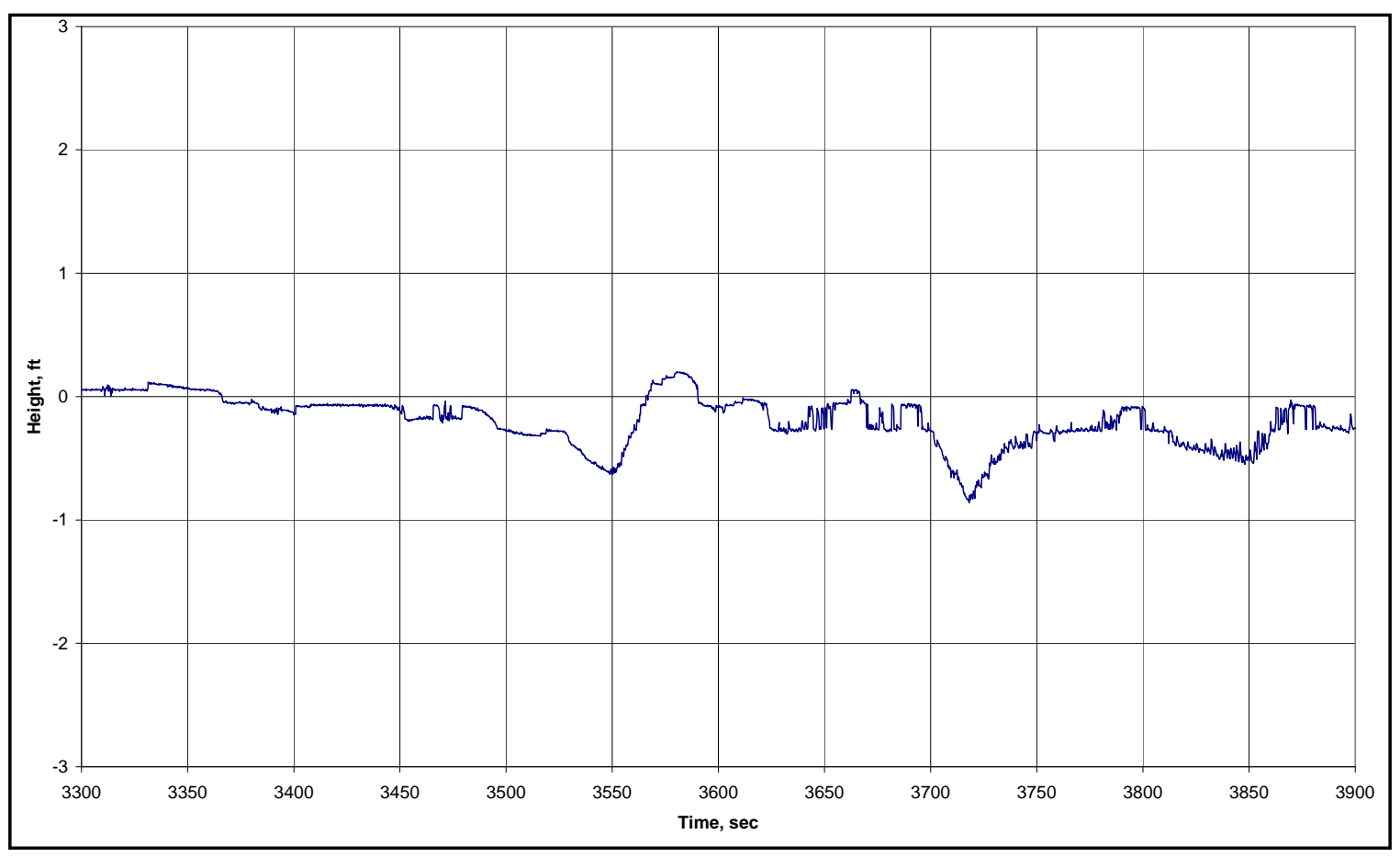

Figure B8. Midnight Sun, outbound, time 0 = 1300 EDT, 18 Sep 2005.

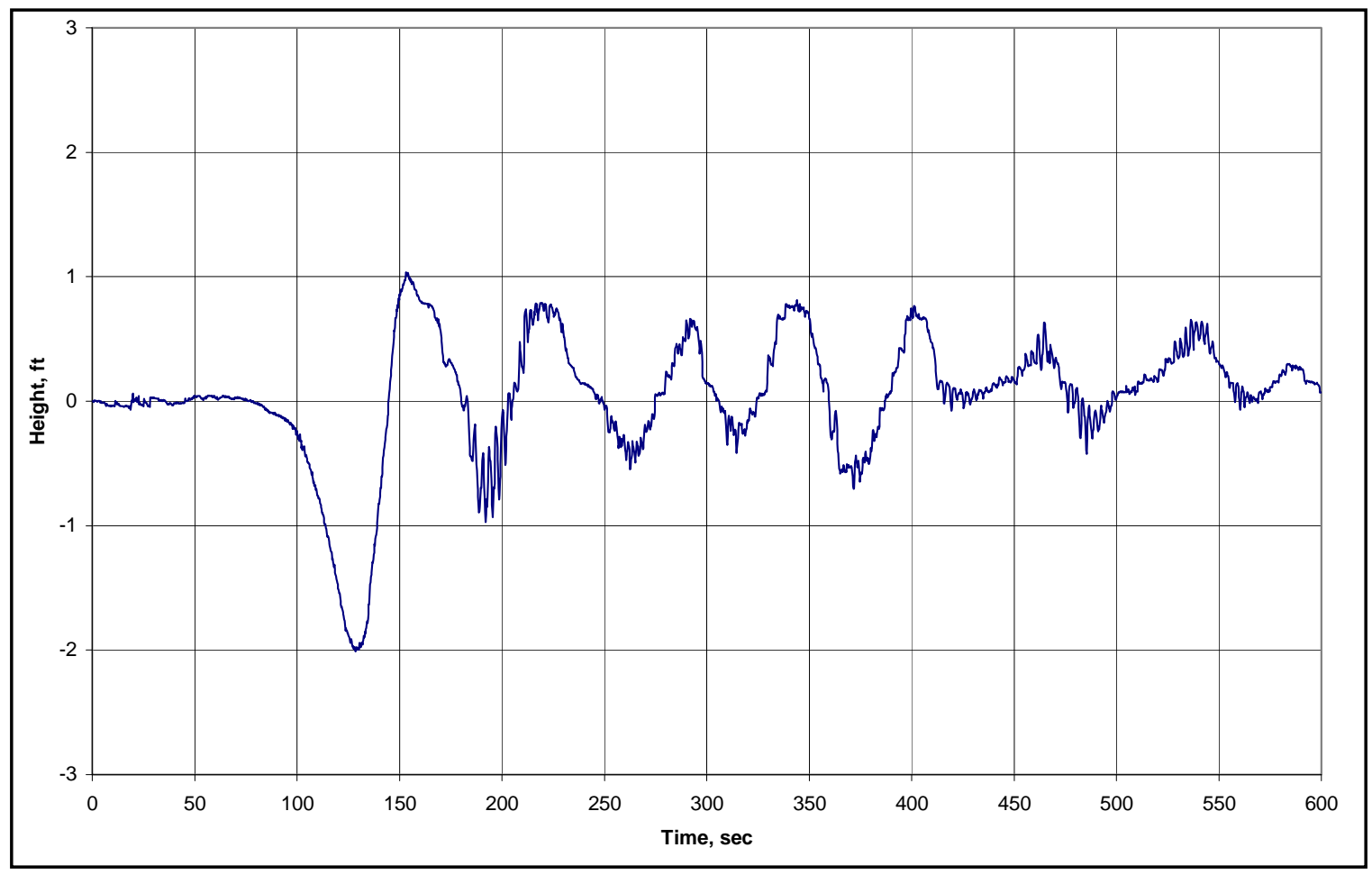

Figure B9. Zim Iberia and Darya Rani, inbound, time 0 = 2100 EDT, 18 Sep 2005. 


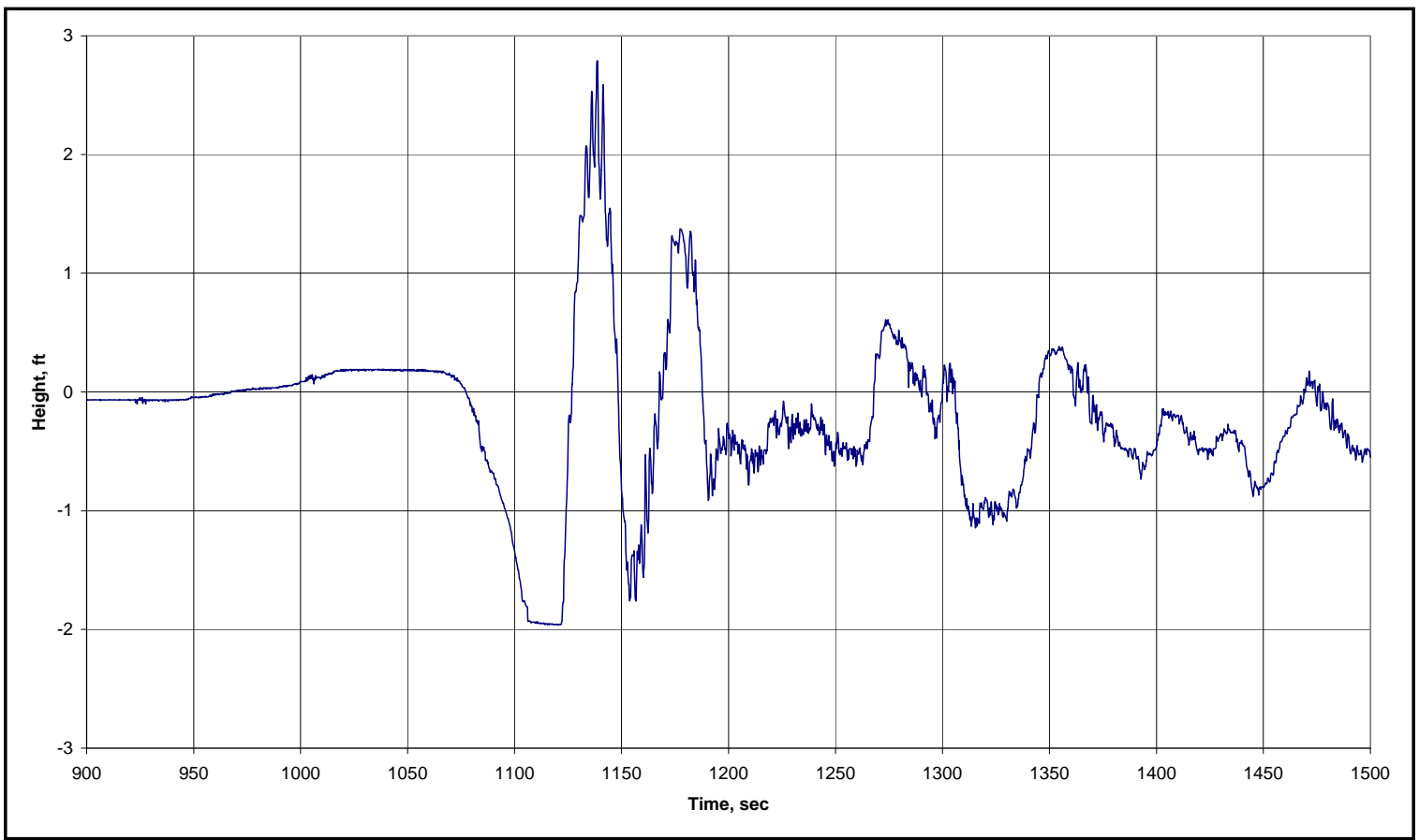

Figure B10. MSC Elena, outbound, time 0 = 0300 EDT, 19 Sep 2005.

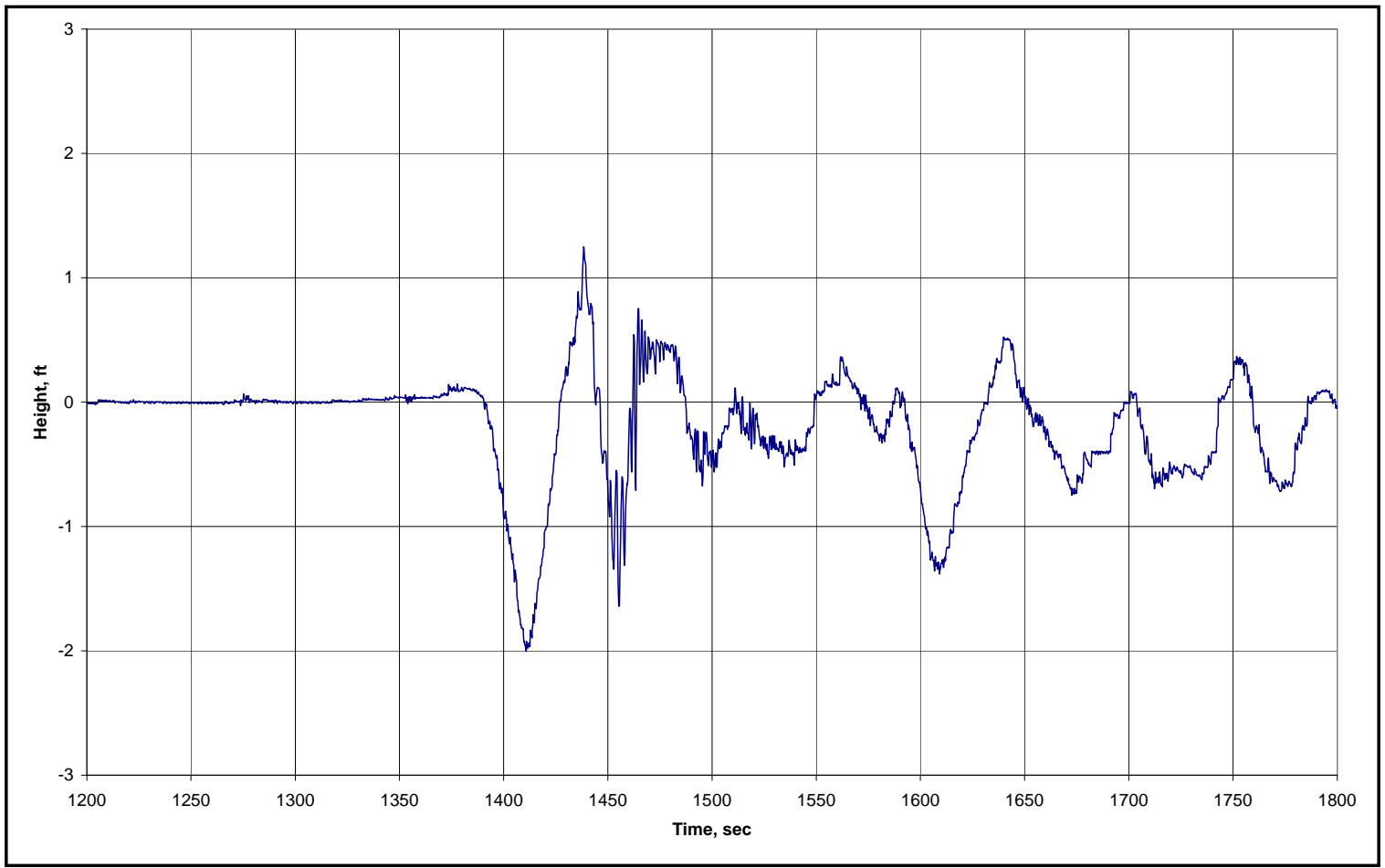

Figure B11. Condor, outbound, time 0 = 1400 EDT, 19 Sep 2005. 


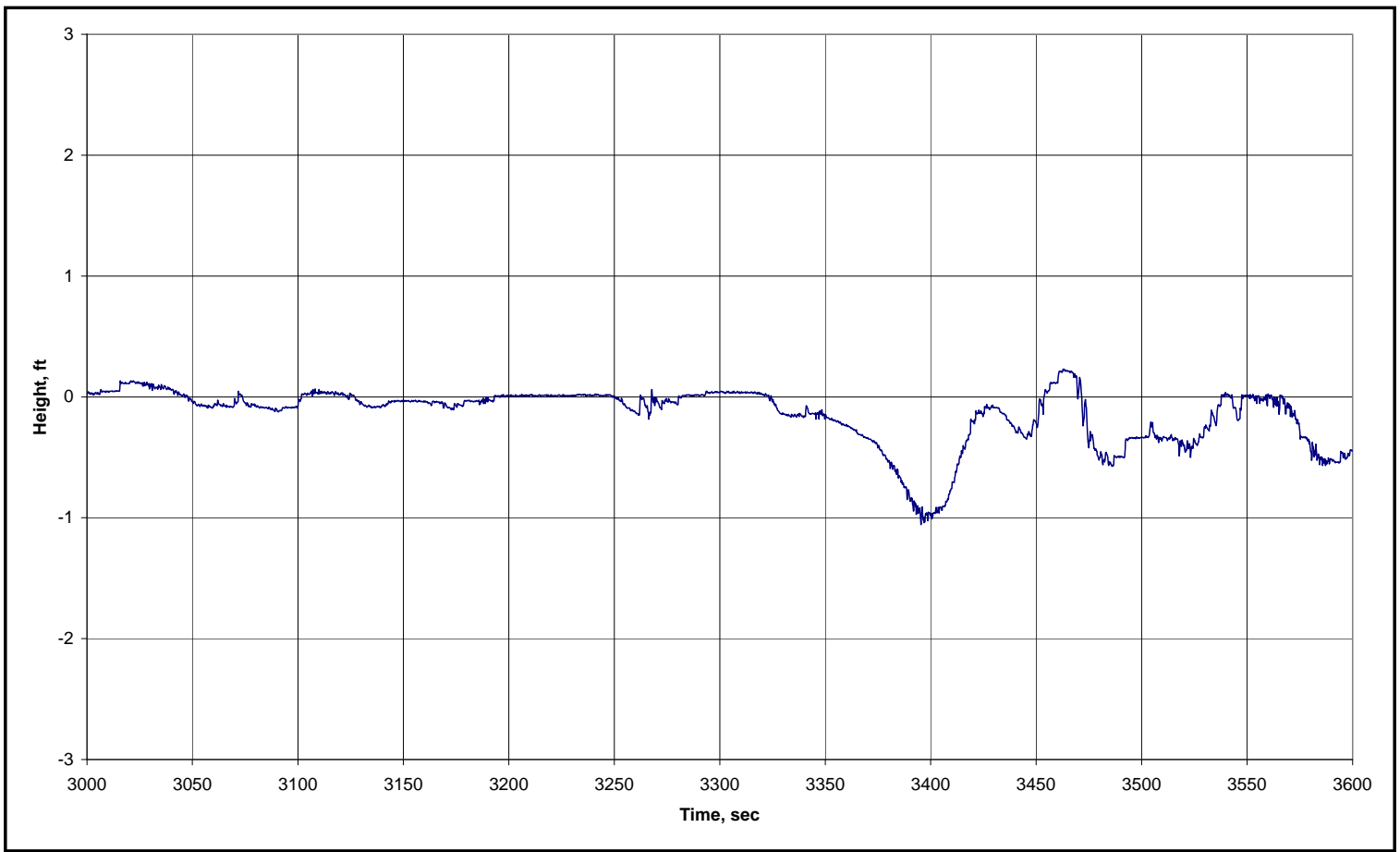

Figure B12. Emmanuel Tomassos, outbound, time 0 = 1400 EDT, 19 Sep 2005.

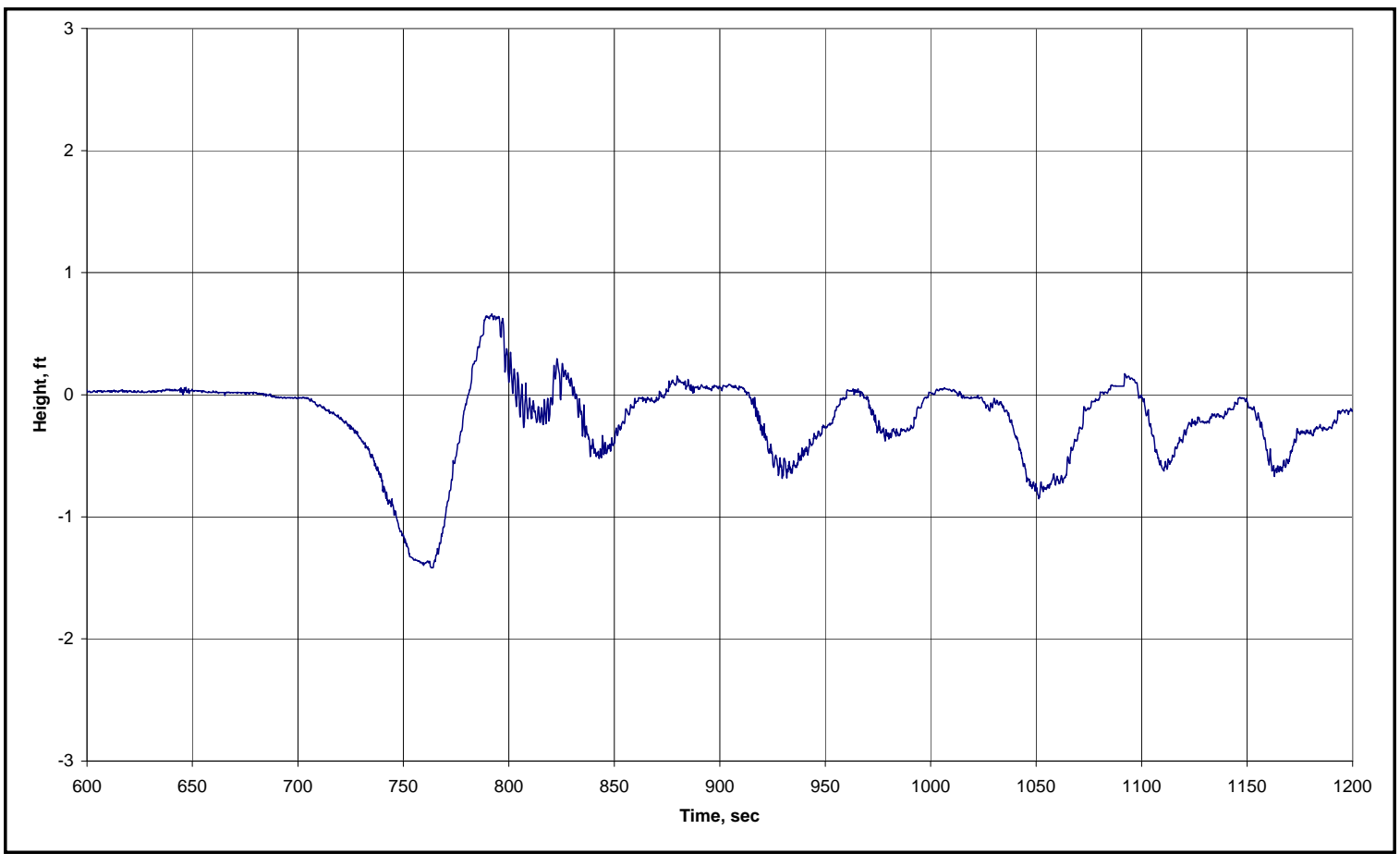

Figure B13. Essen Express, outbound, time 0 = 0300 EDT, 20 Sep 2005. 


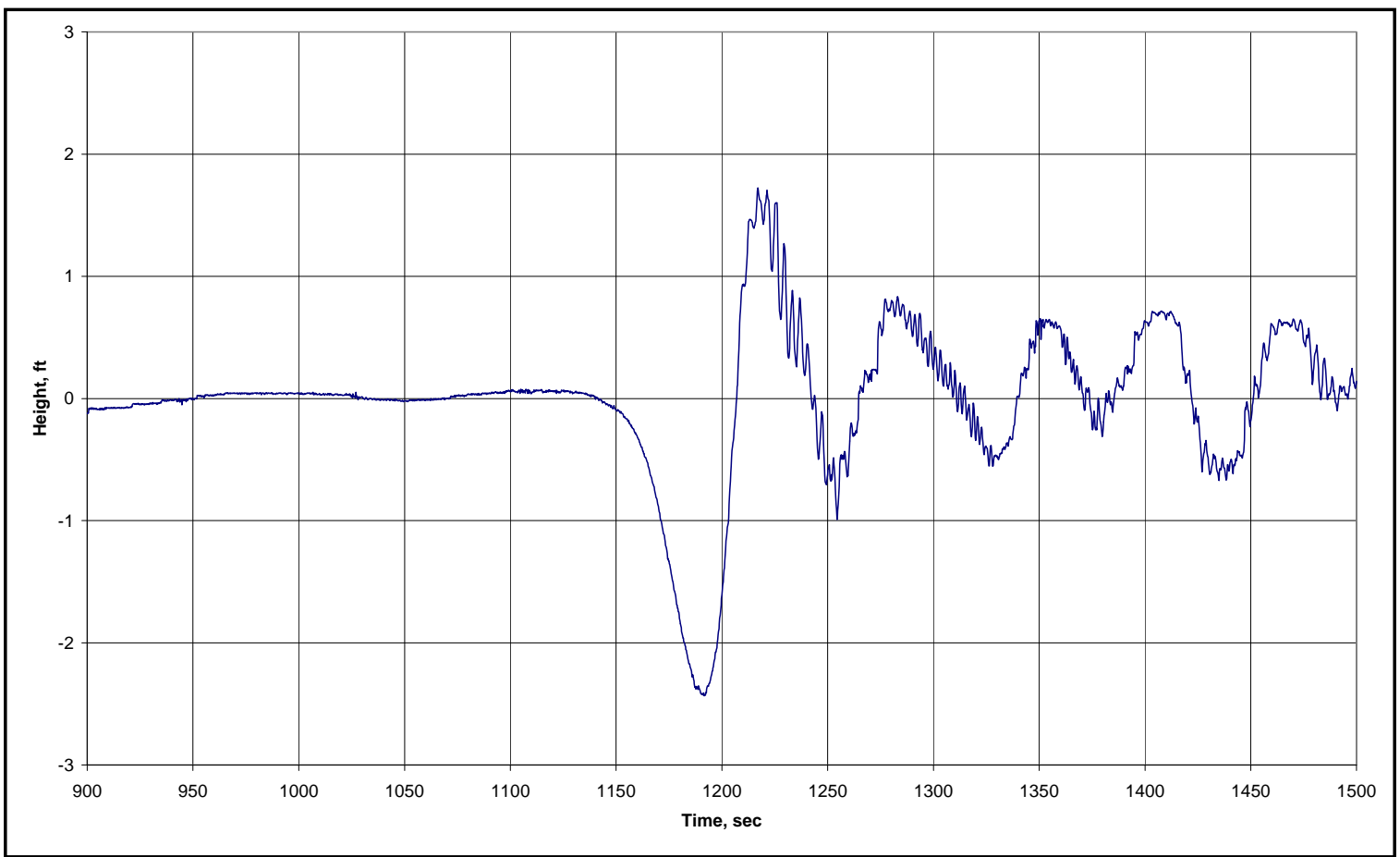

Figure B14. Mol Velocity, outbound, time 0 = 0900 EDT, 20 Sep 2005.

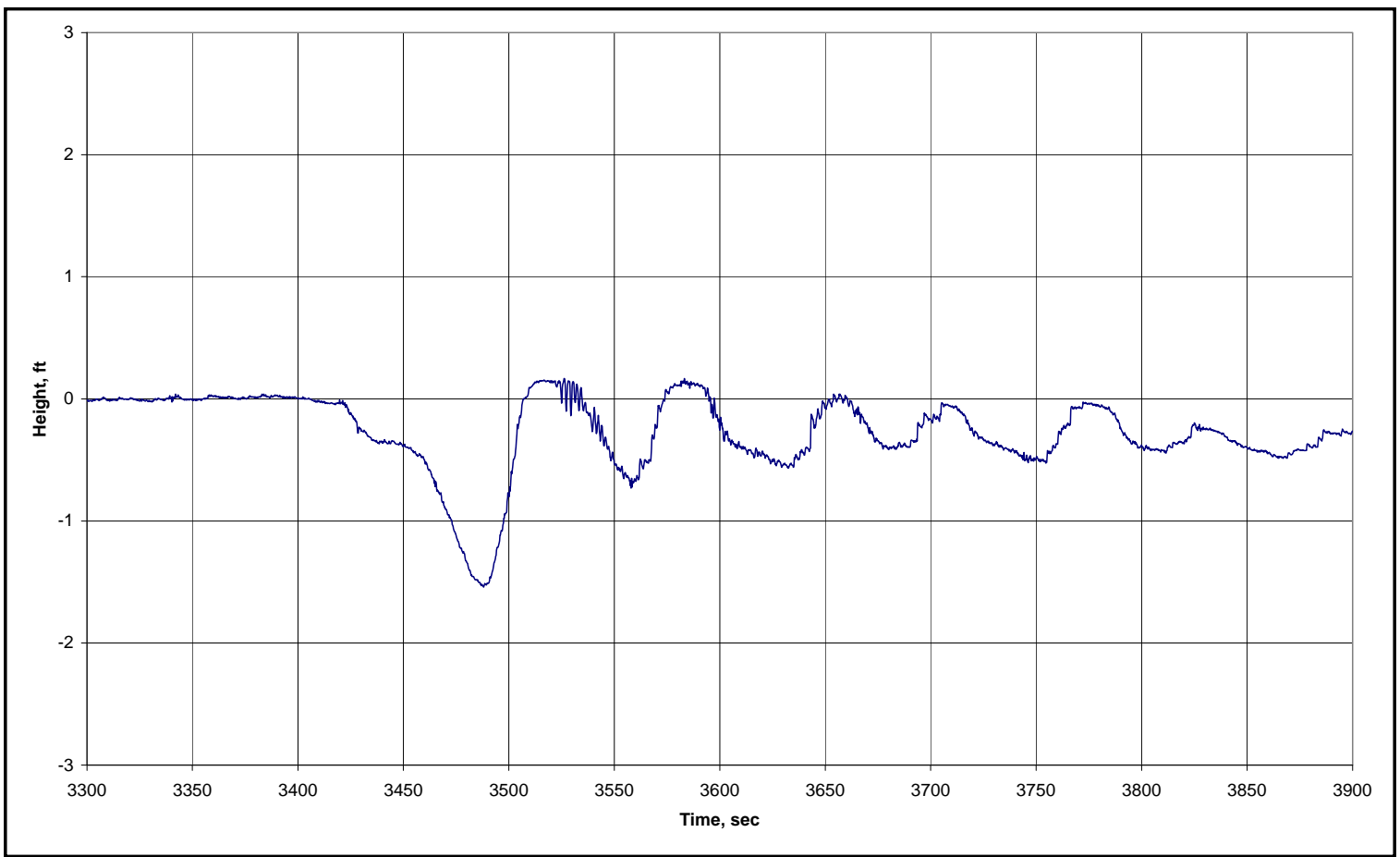

Figure B15. Jervis Bay, outbound, time 0 = 0100 EDT, 21 Sep 2005. 


\section{Appendix C: Ship Wave Height at Fort Pulaski, Wave Gauge CH2}

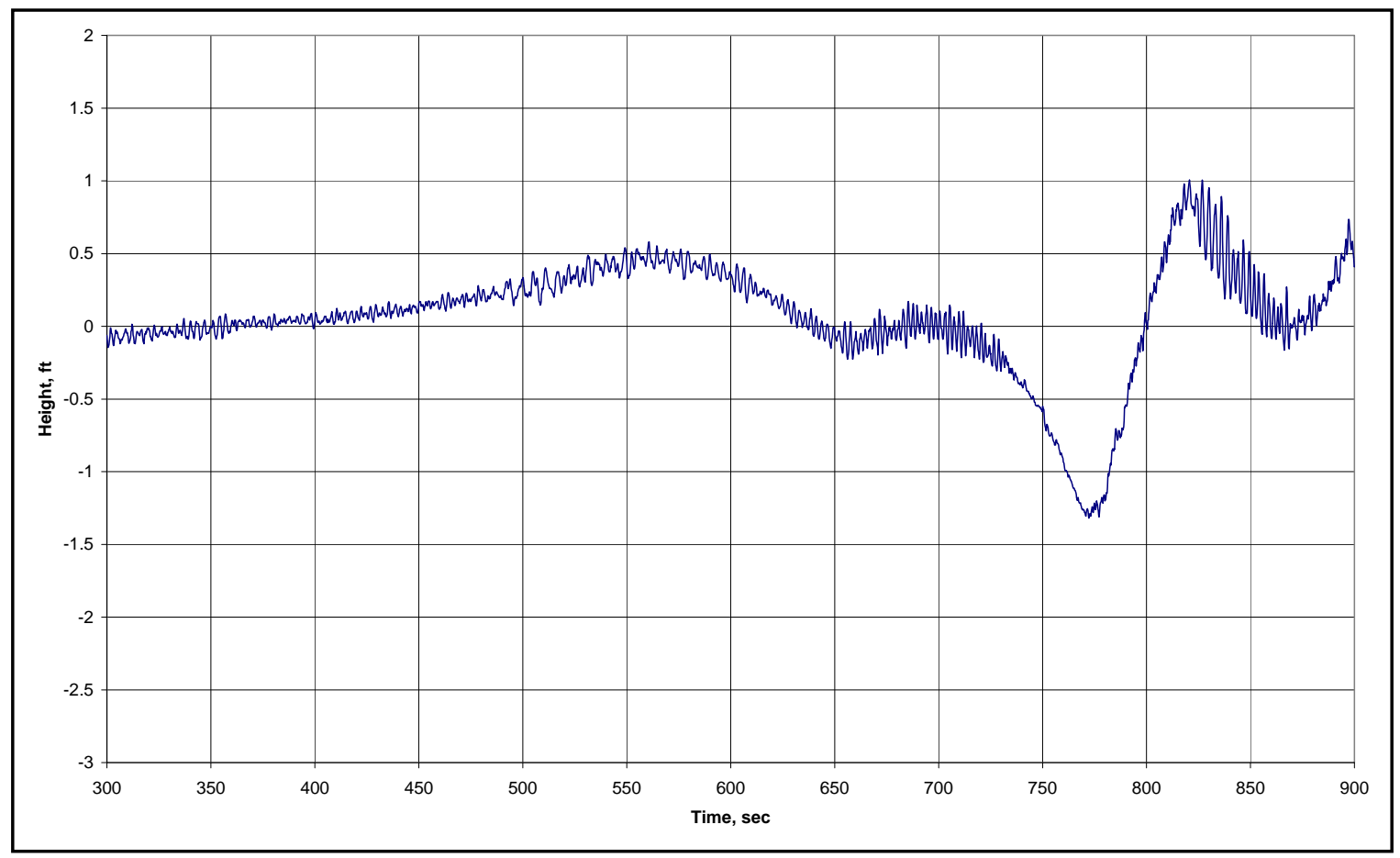

Figure C1. Sun Right, inbound, time 0 = 1500 EDT, 16 Sep 2005. 


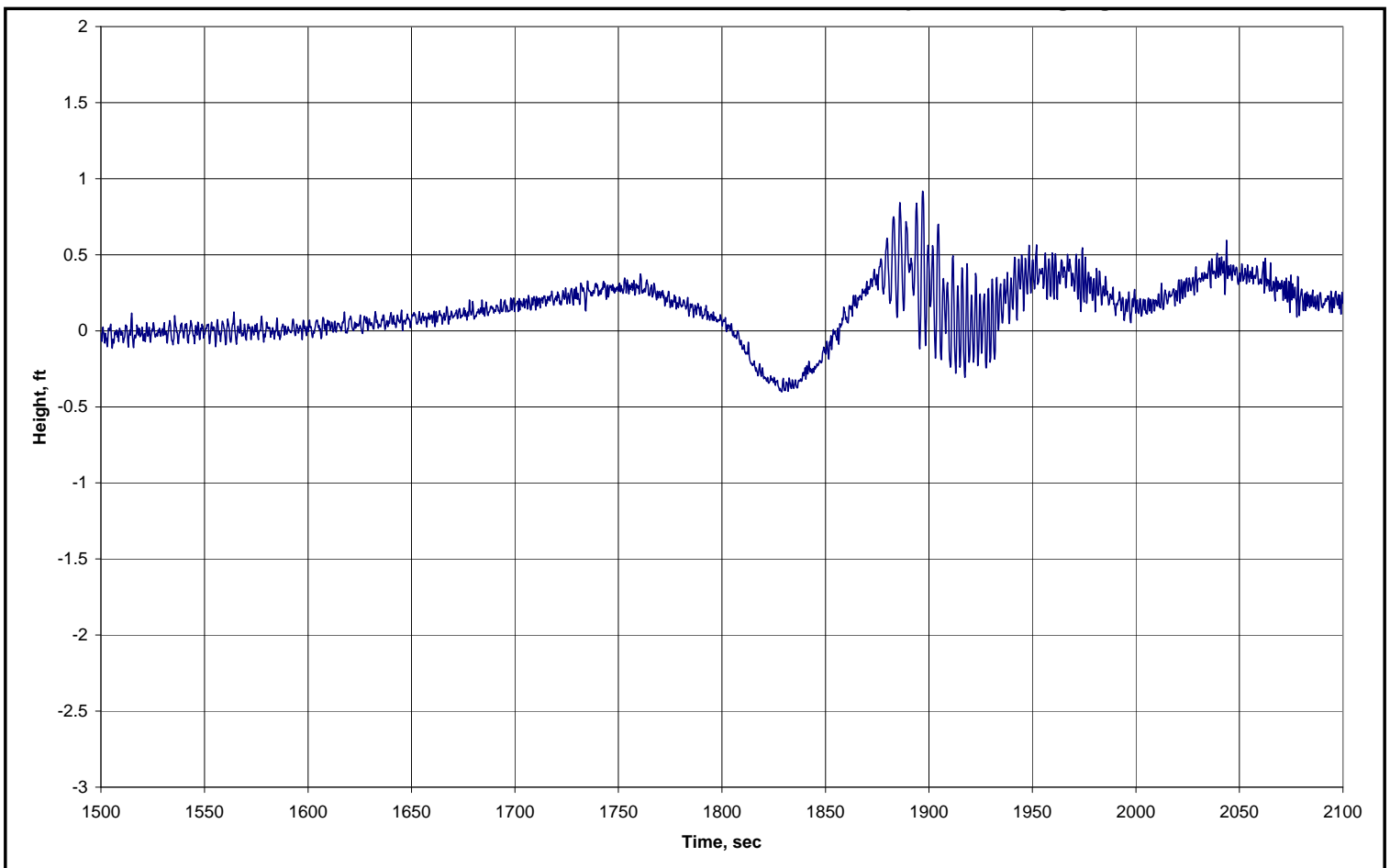

Figure C2. Mol Americas, inbound, time 0 = 1700 EDT, 16 Sep 2005.

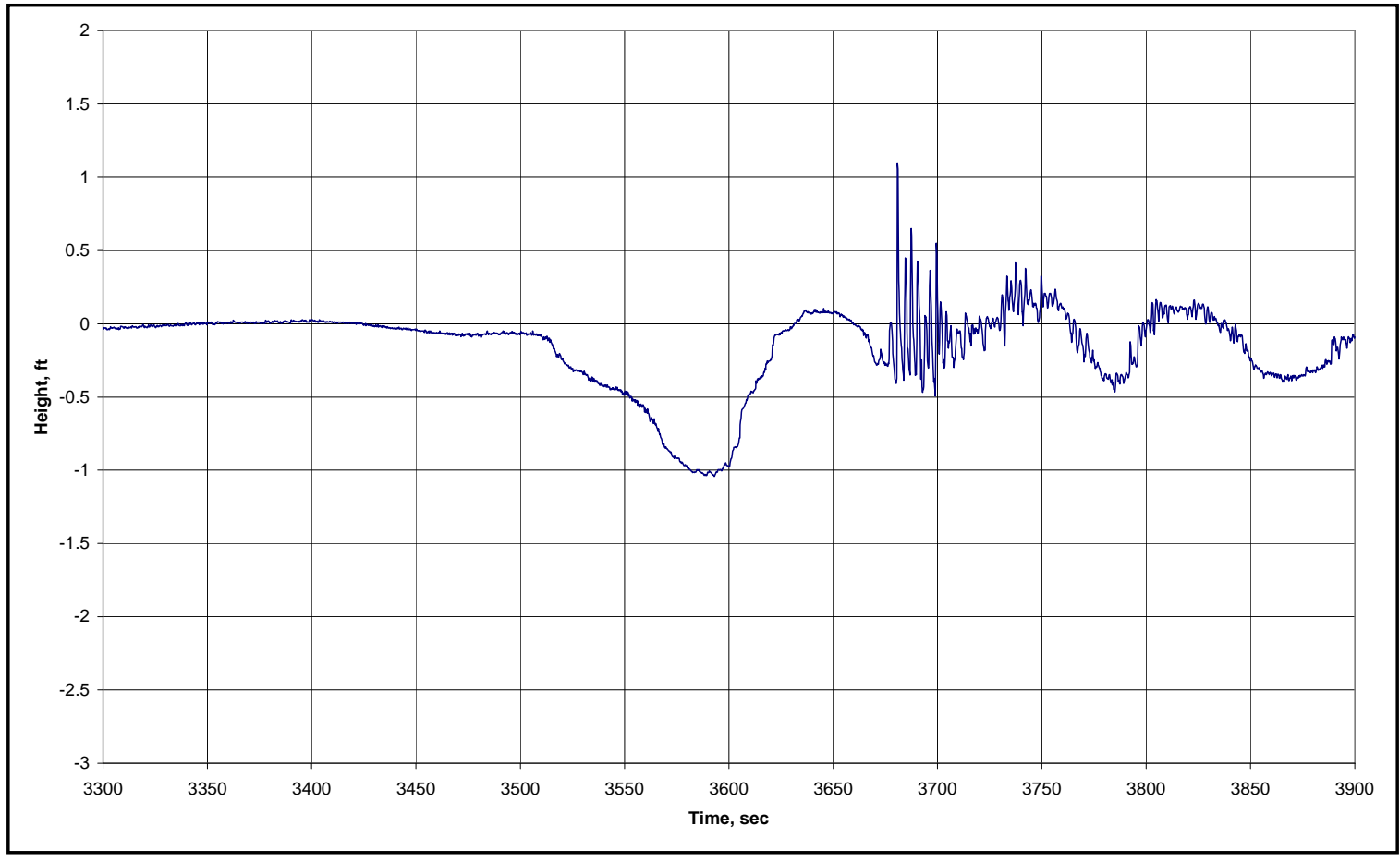

Figure C3. Zim Israel, inbound, time 0 = 0100 EDT, 17 Sep 2005. 


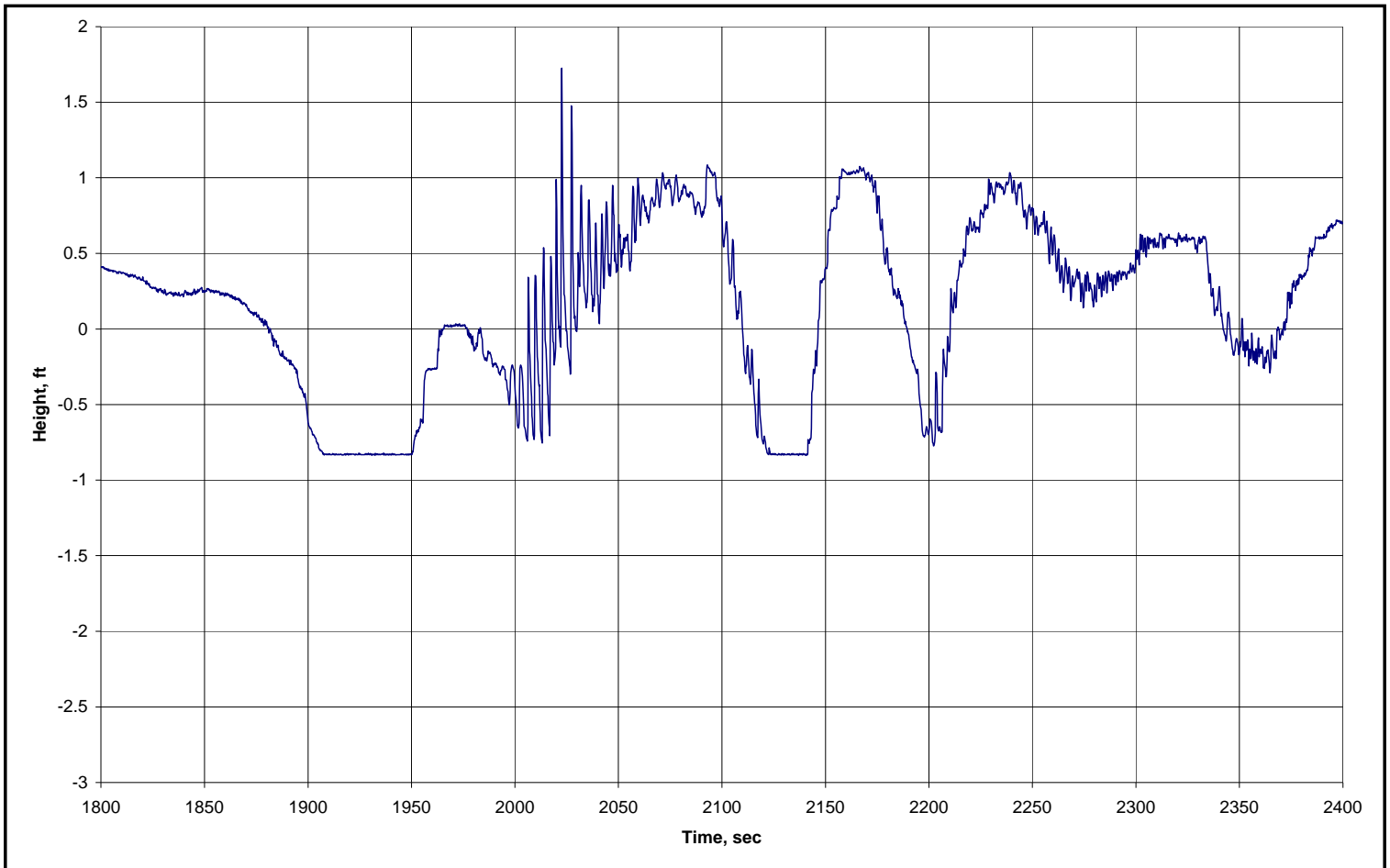

Figure C4. MSC Christinia, inbound, time 0 = 0200 EDT, 17 Sep 2005.

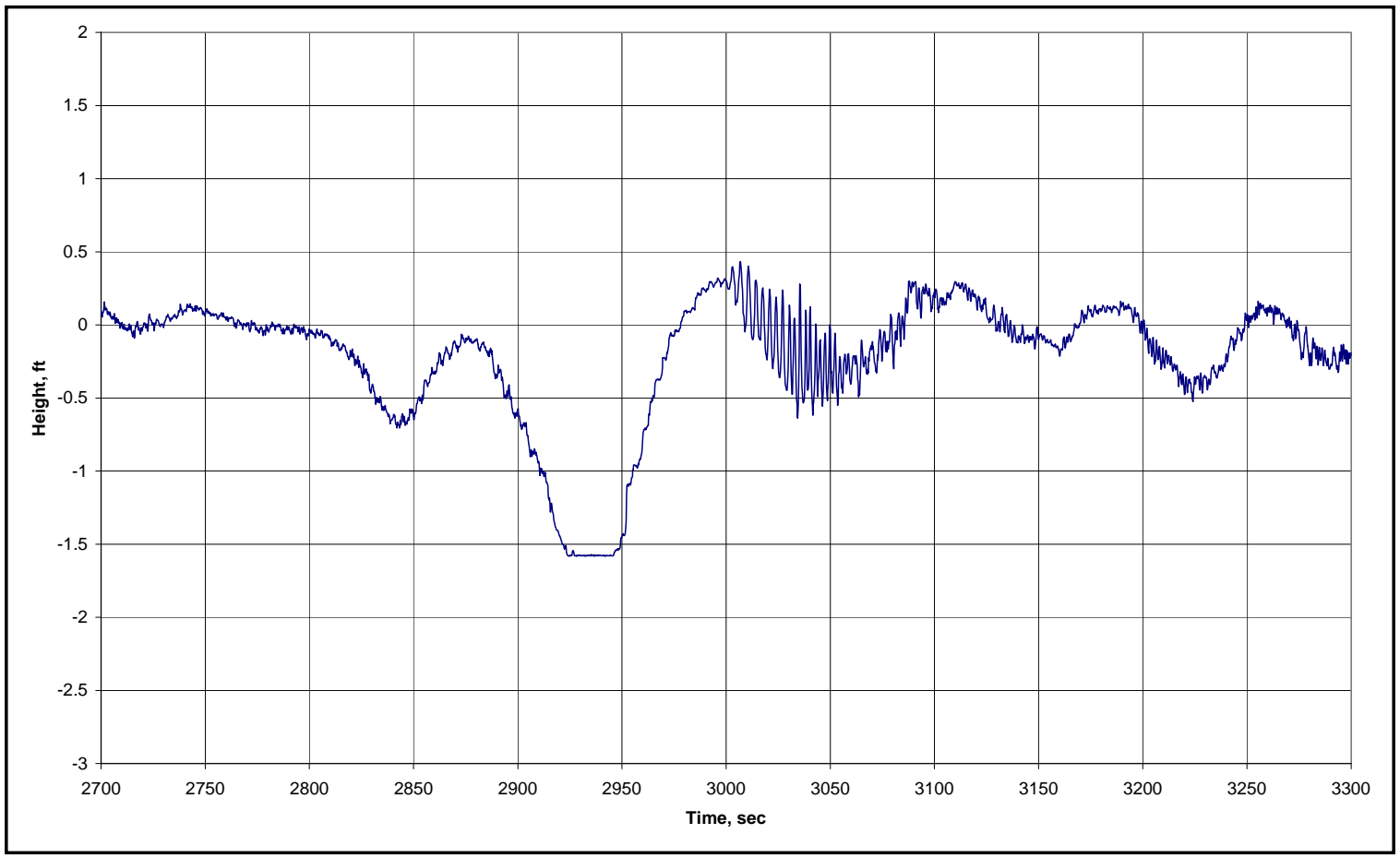

Figure C5. Mol Elbe, inbound, time 0 = 0200 EDT, 17 Sep 2005. 


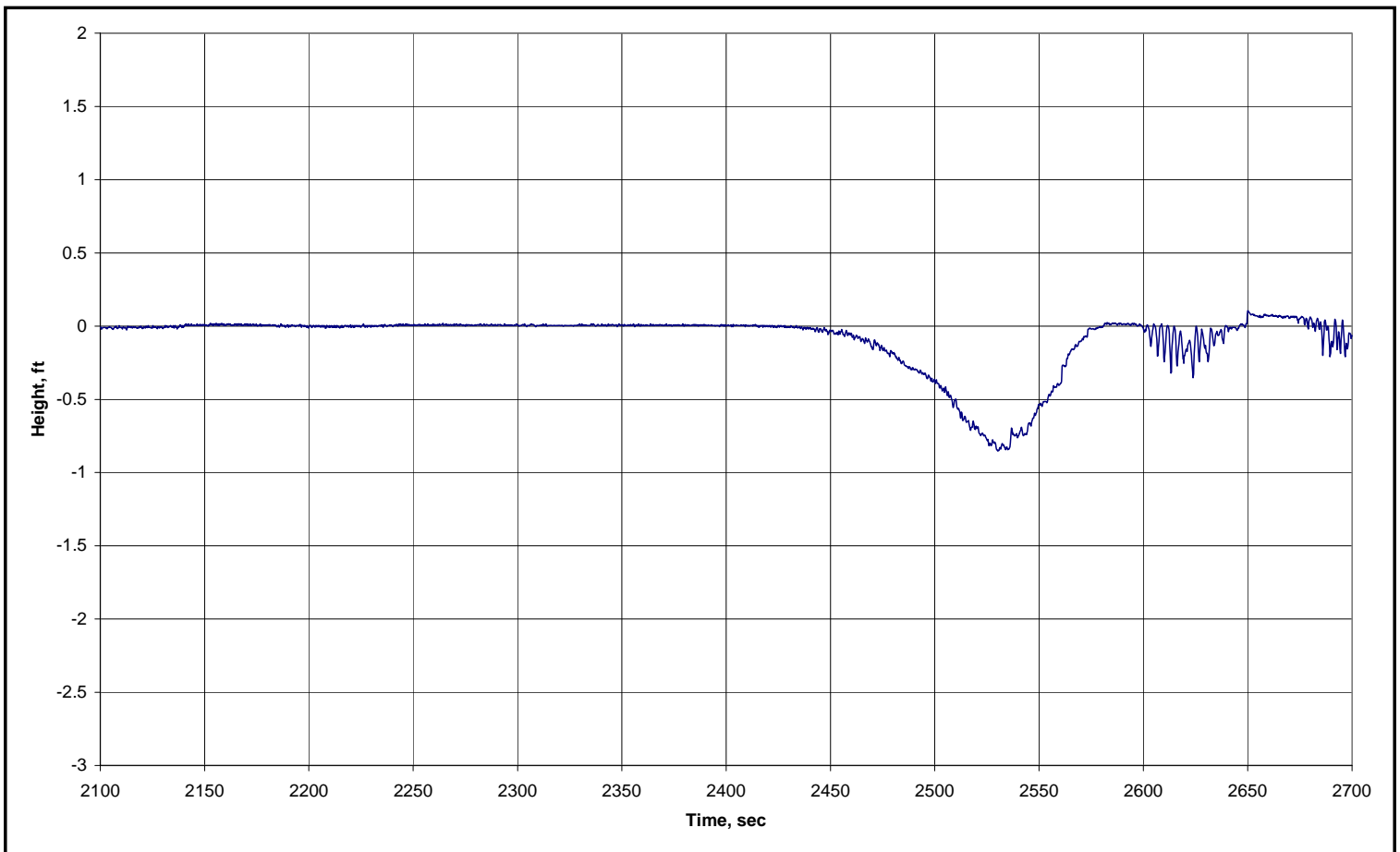

Figure C6. MSC Eleni, inbound, time 0 = 0800 EDT, 17 Sep 2005.

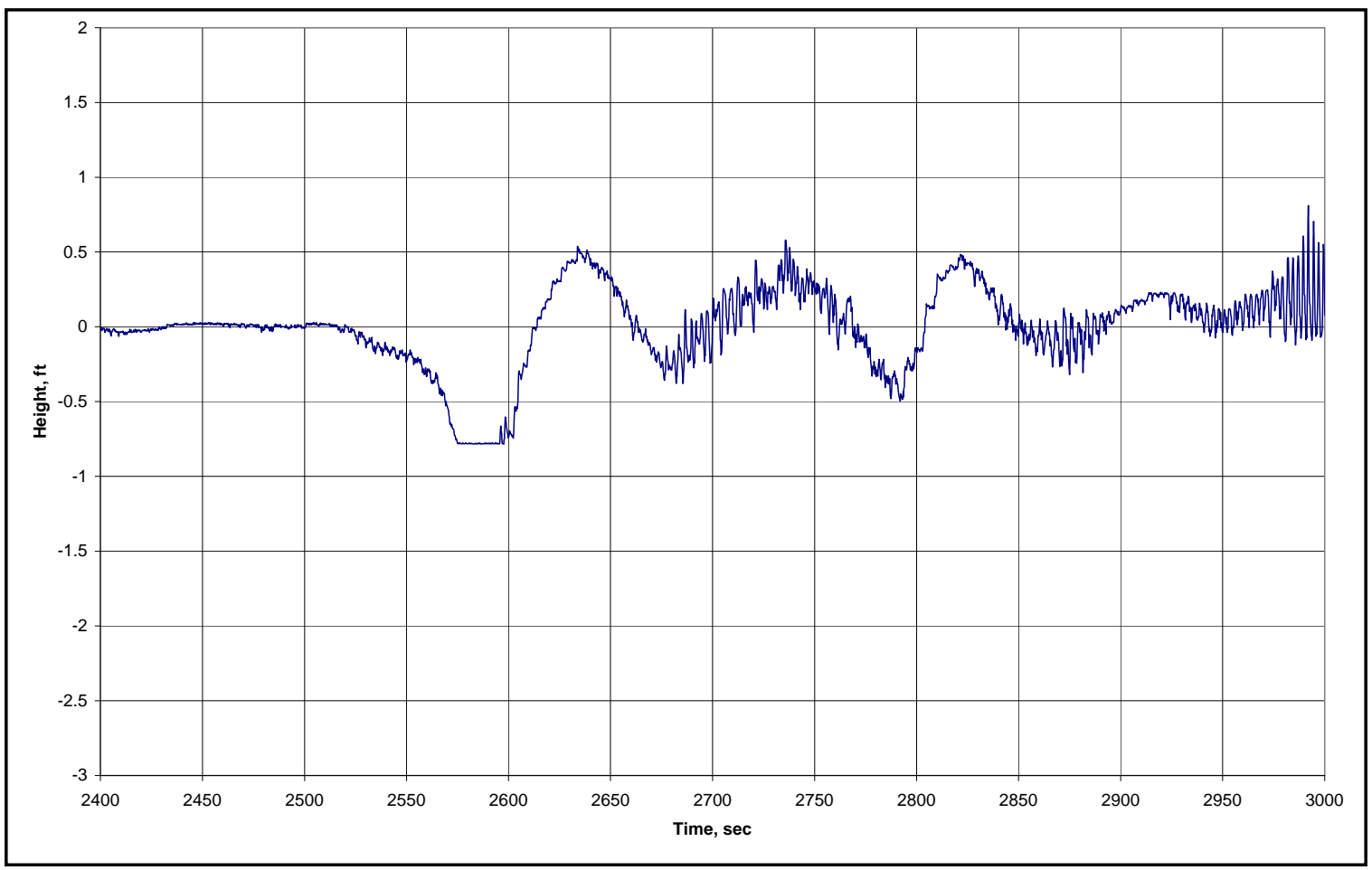

Figure C7. Midnight Sun, inbound, time 0 = 1400 EDT, 17 Sep 2005. 


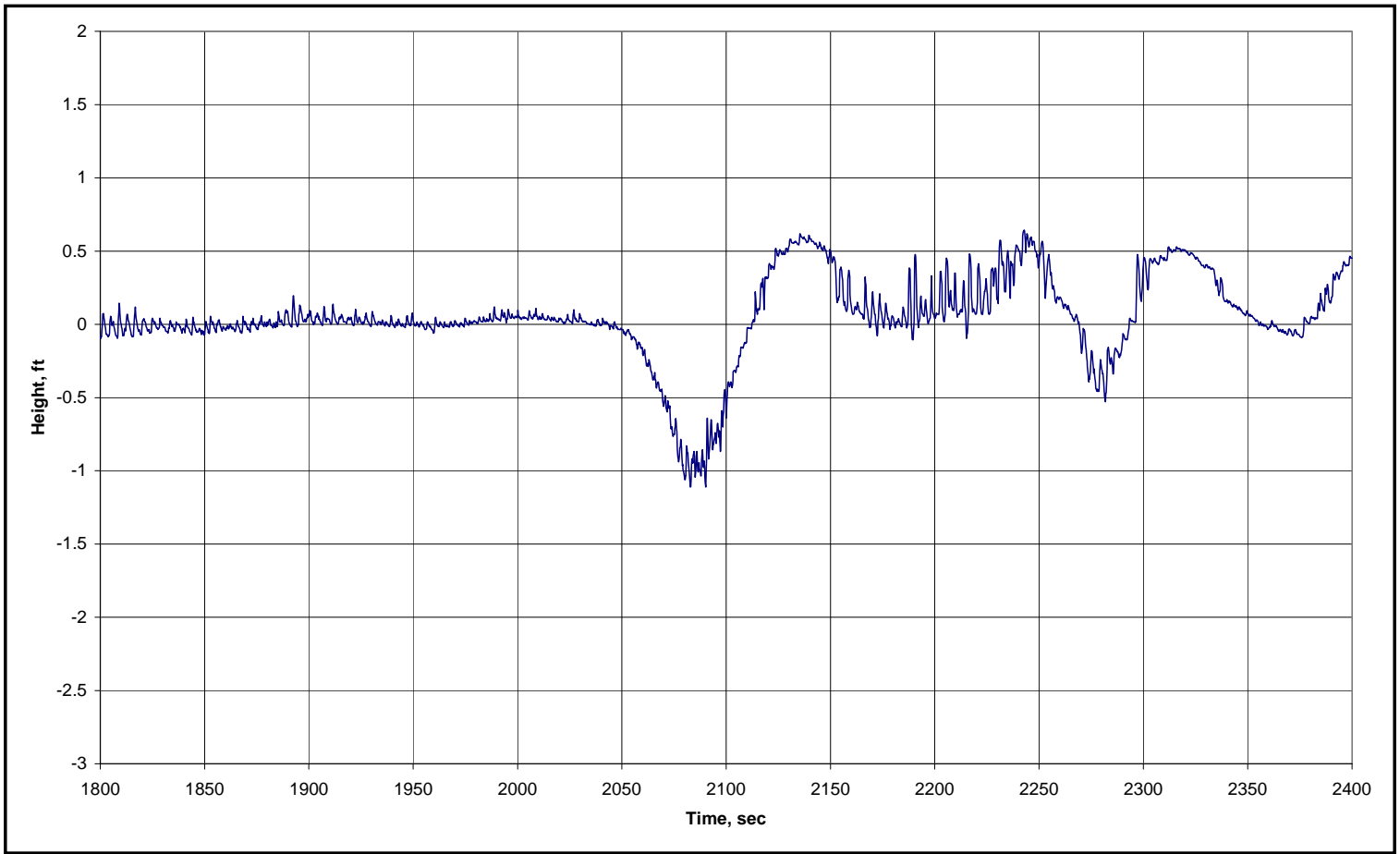

Figure C8. Darya Rani, inbound, time 0 = 1500 EDT, 17 Sep 2005.

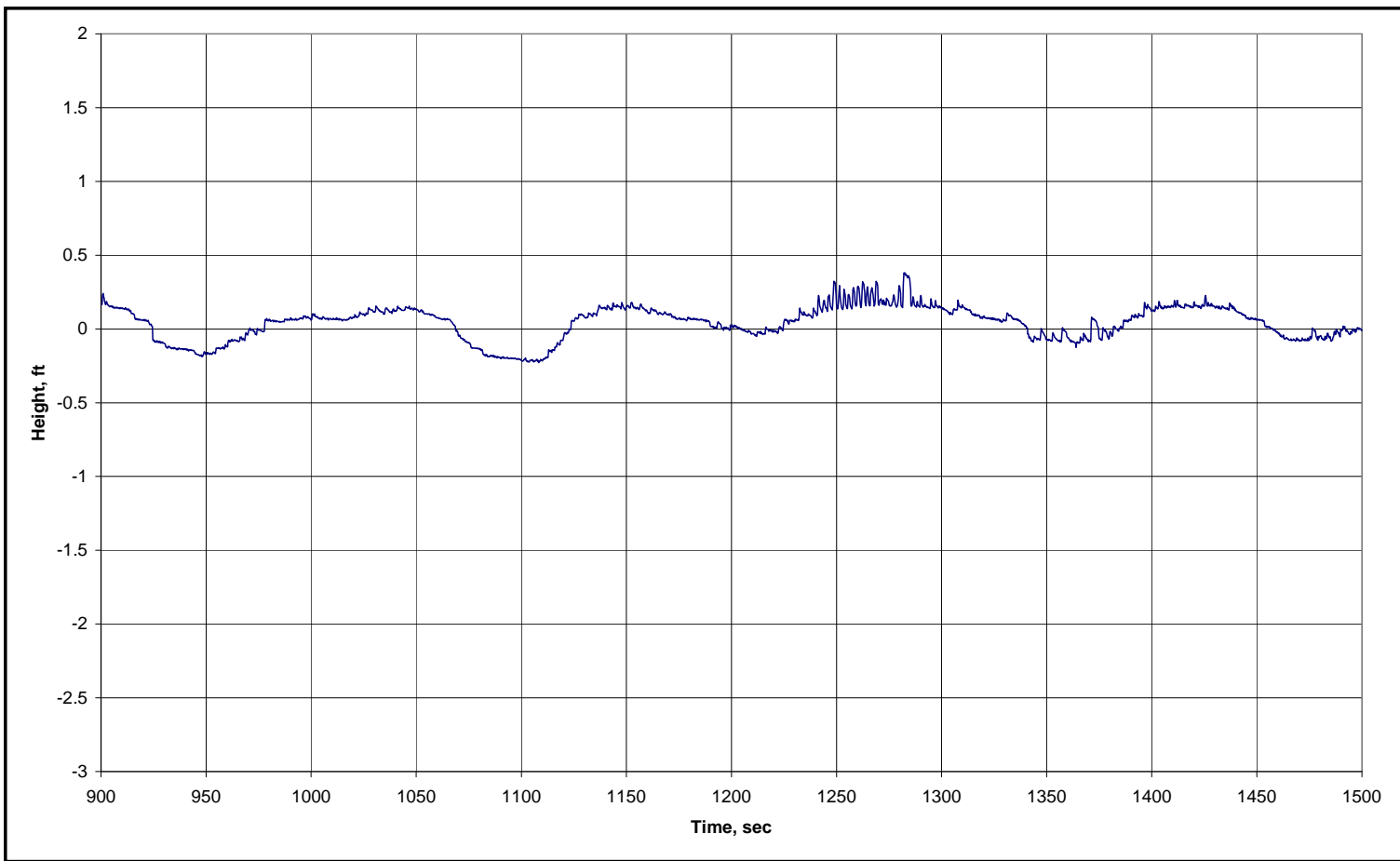

Figure C9. Alyona, inbound, time $0=2100$ EDT, 17 Sep 2005. 


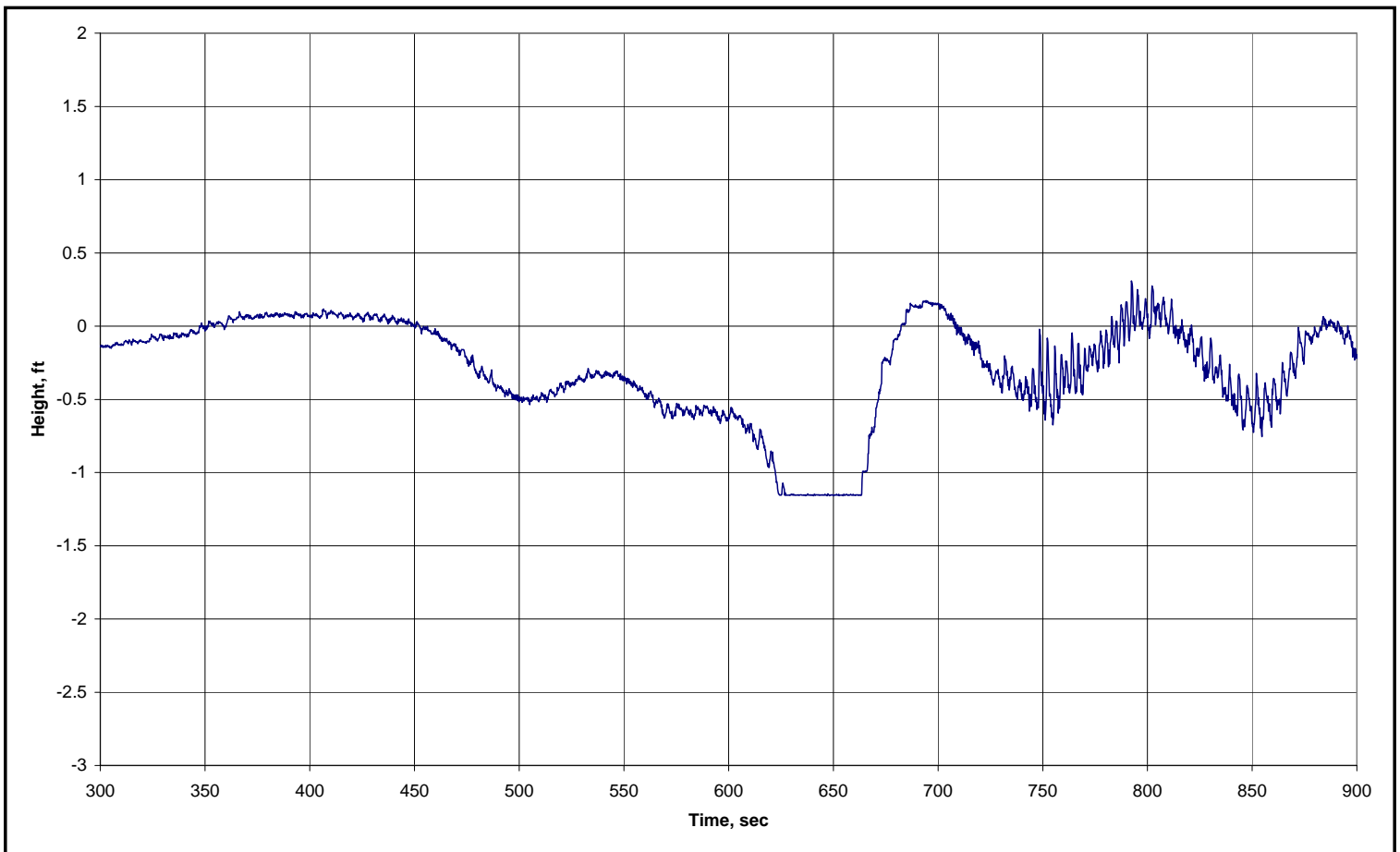

Figure C10. Zim Iberia, inbound, time 0 = 0300 EDT, 18 Sep 2005.

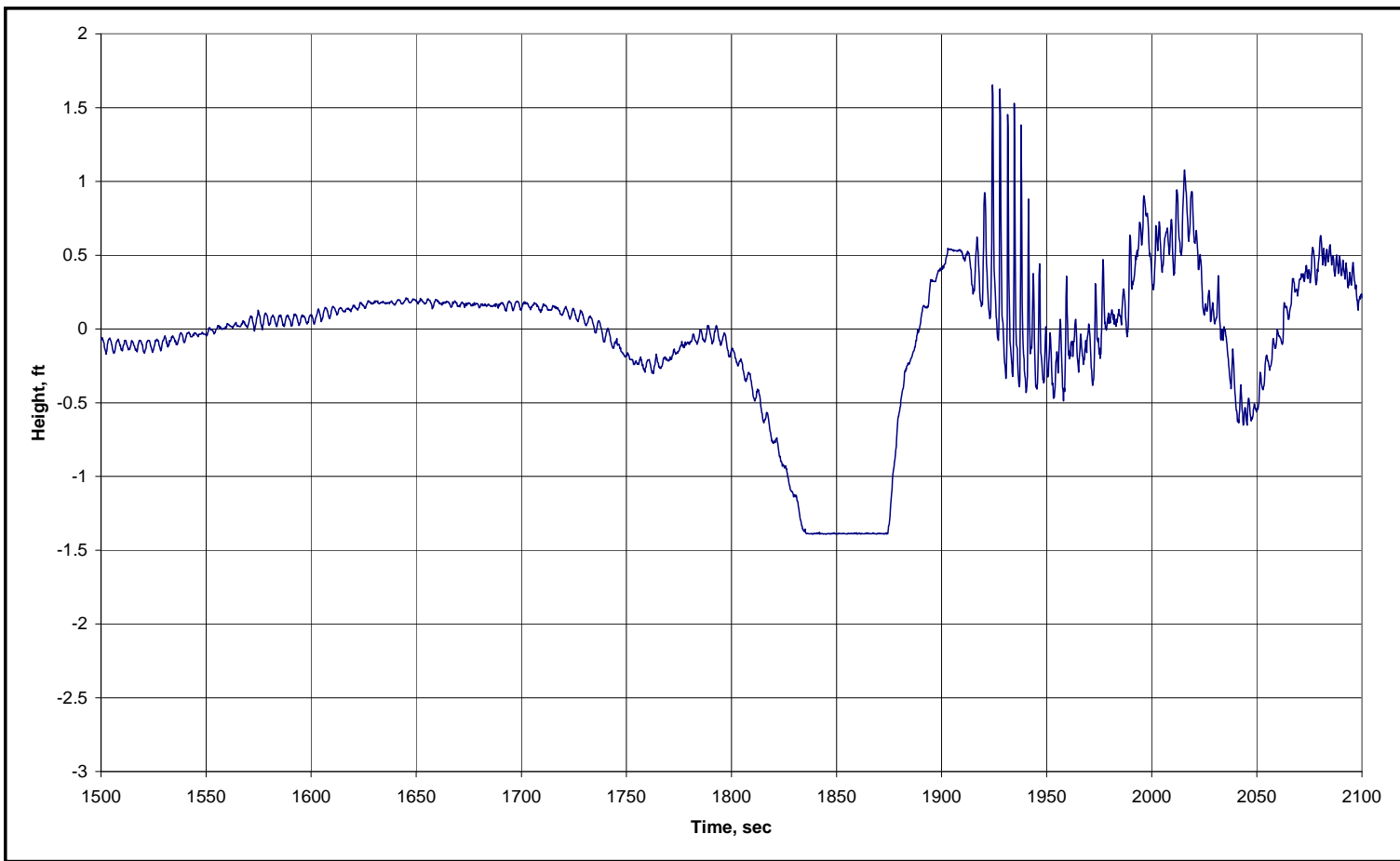

Figure C11. Essen Express, inbound, time 0 = 0400 EDT, 19 Sep 2005. 


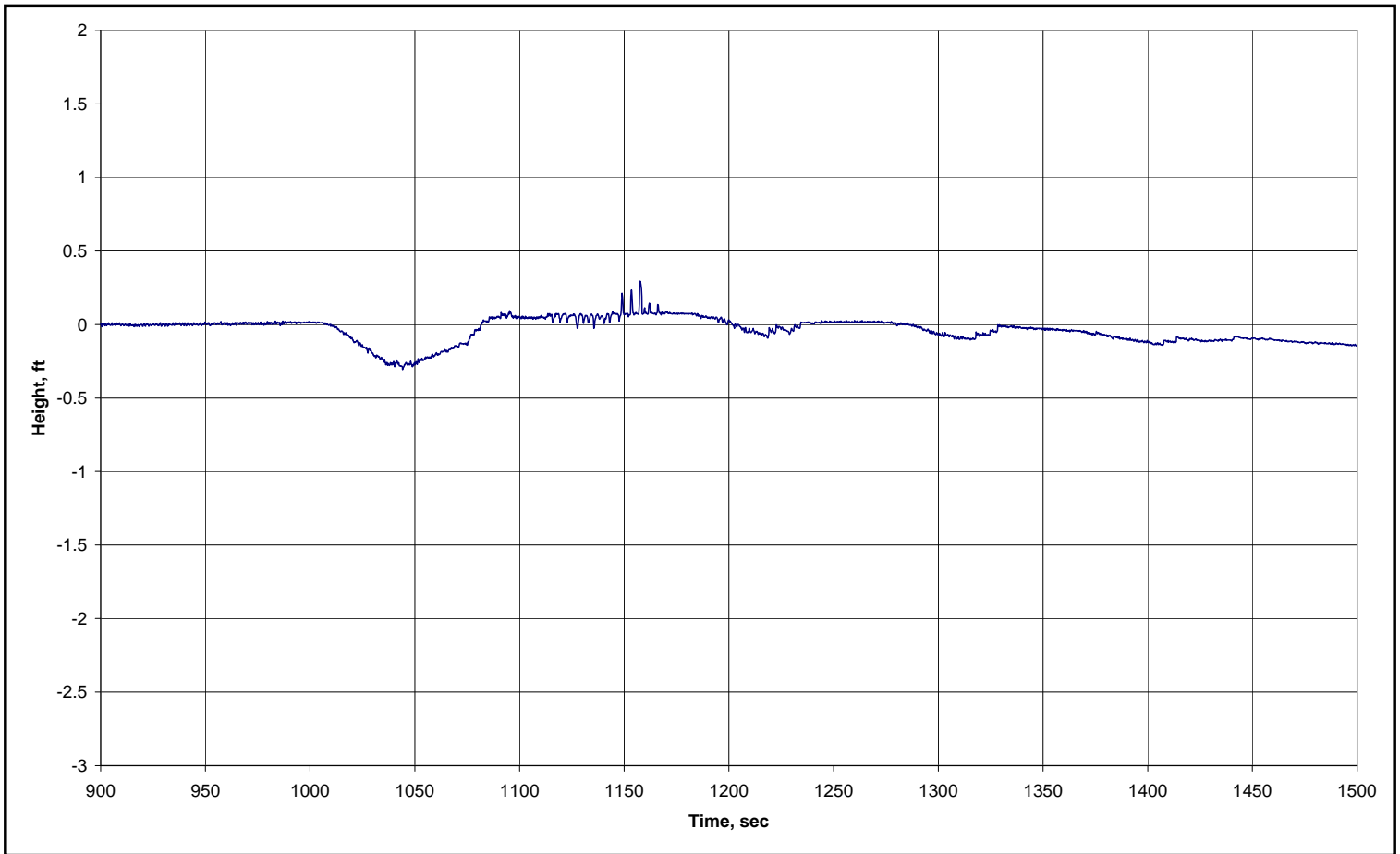

Figure C12. Al Mariyah, inbound, time 0 = 0900 EDT, 18 Sep 2005.

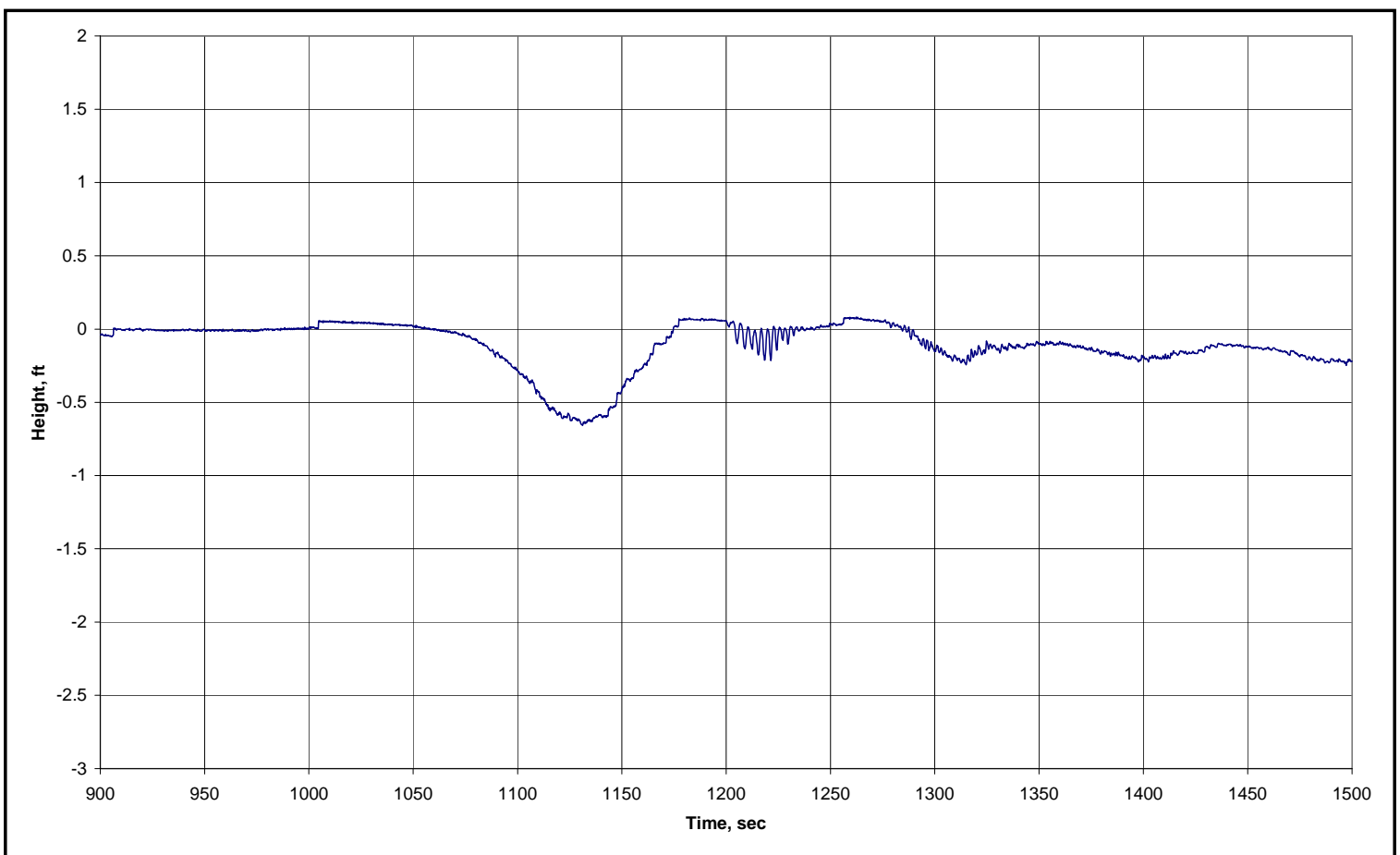

Figure C13. MSC Elena, inbound, time 0 = 1000 EDT, 18 Sep 2005. 
ERDC/CHL TR-07-7

88

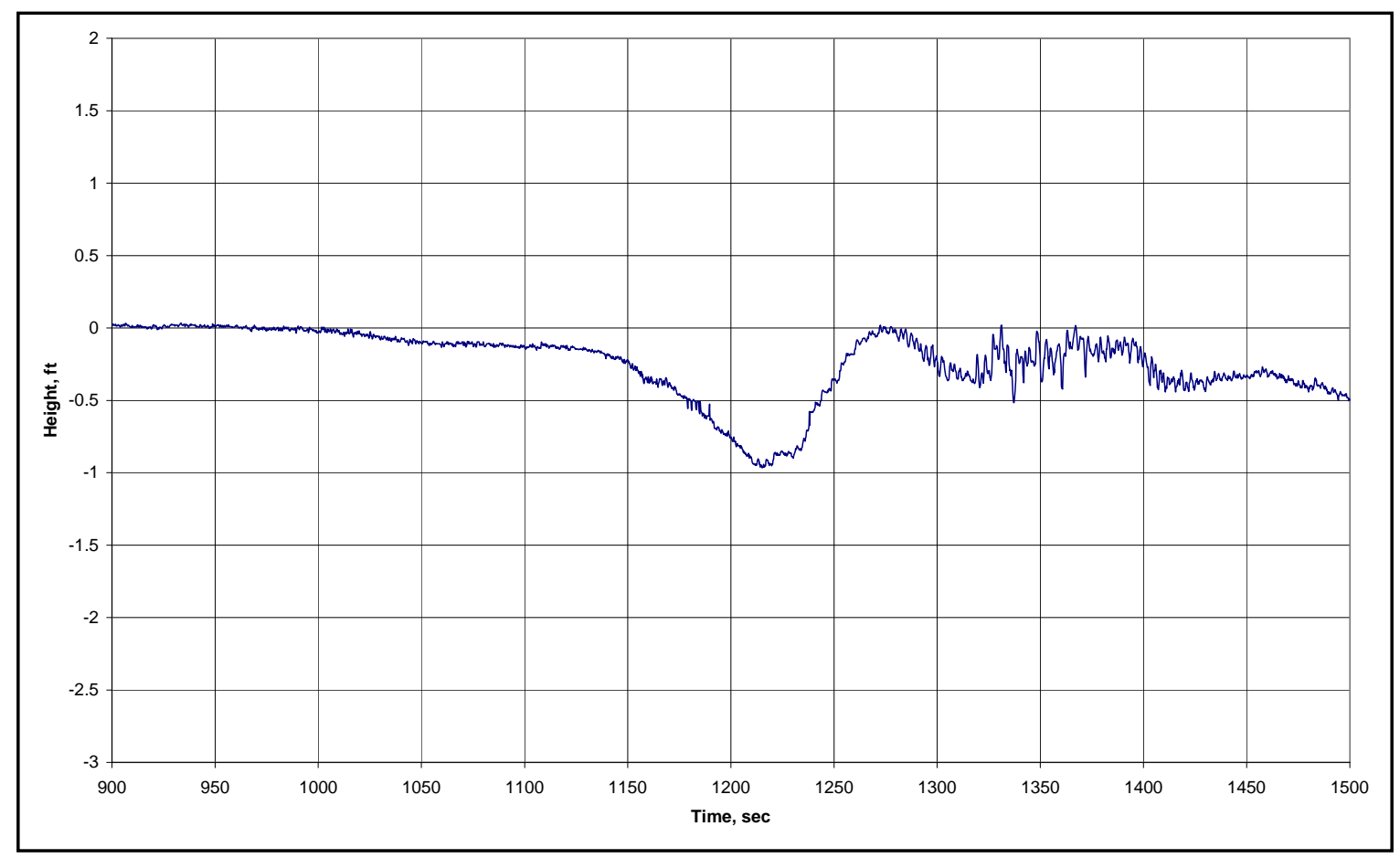

Figure C14. Emmanuelle Tomassos, inbound, time 0 = 1300 EDT, 18 Sep 2005.

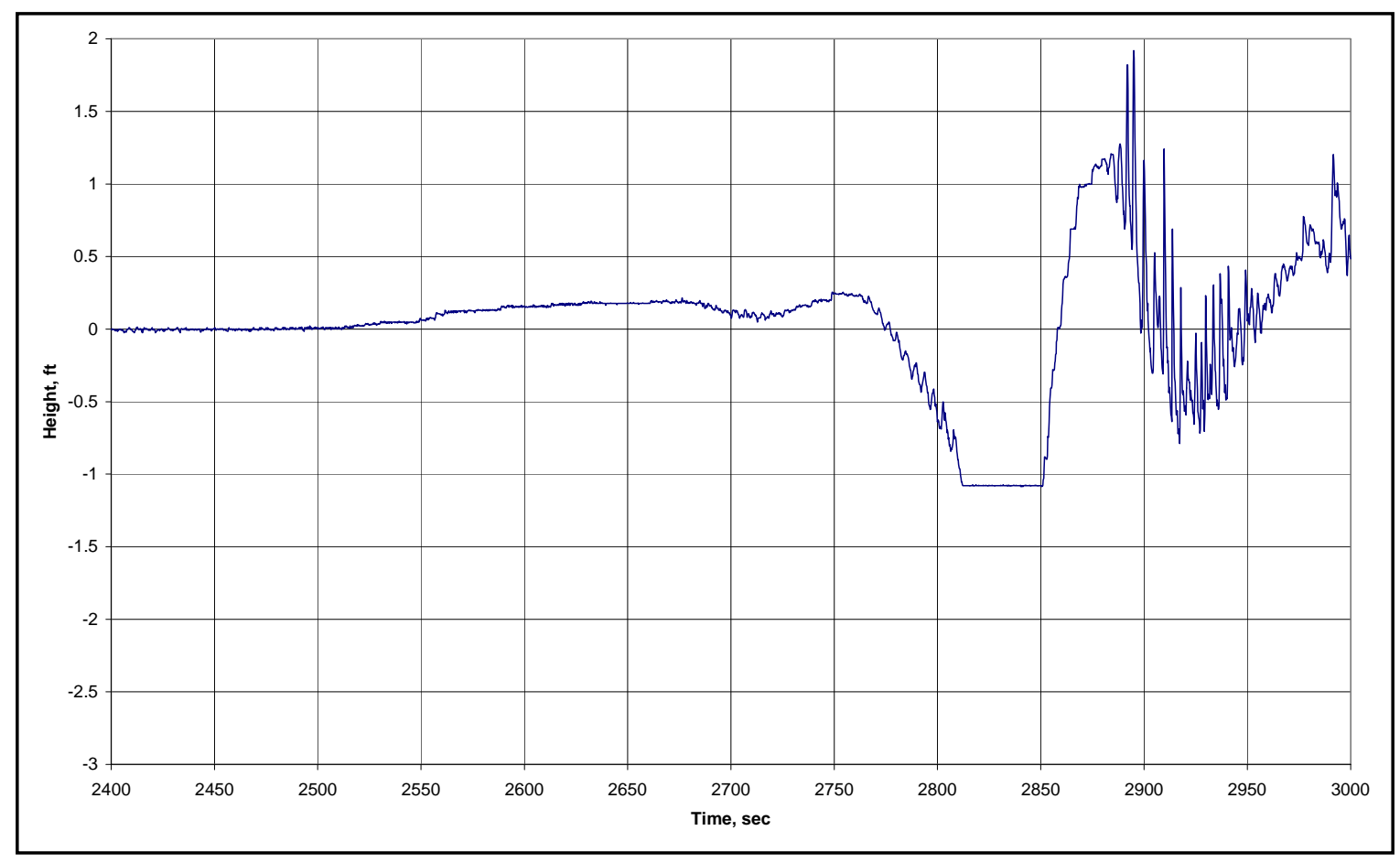

Figure C15. Hanjin Wilmington, inbound, time 0 = 1500 EDT, 18 Sep 2005. 


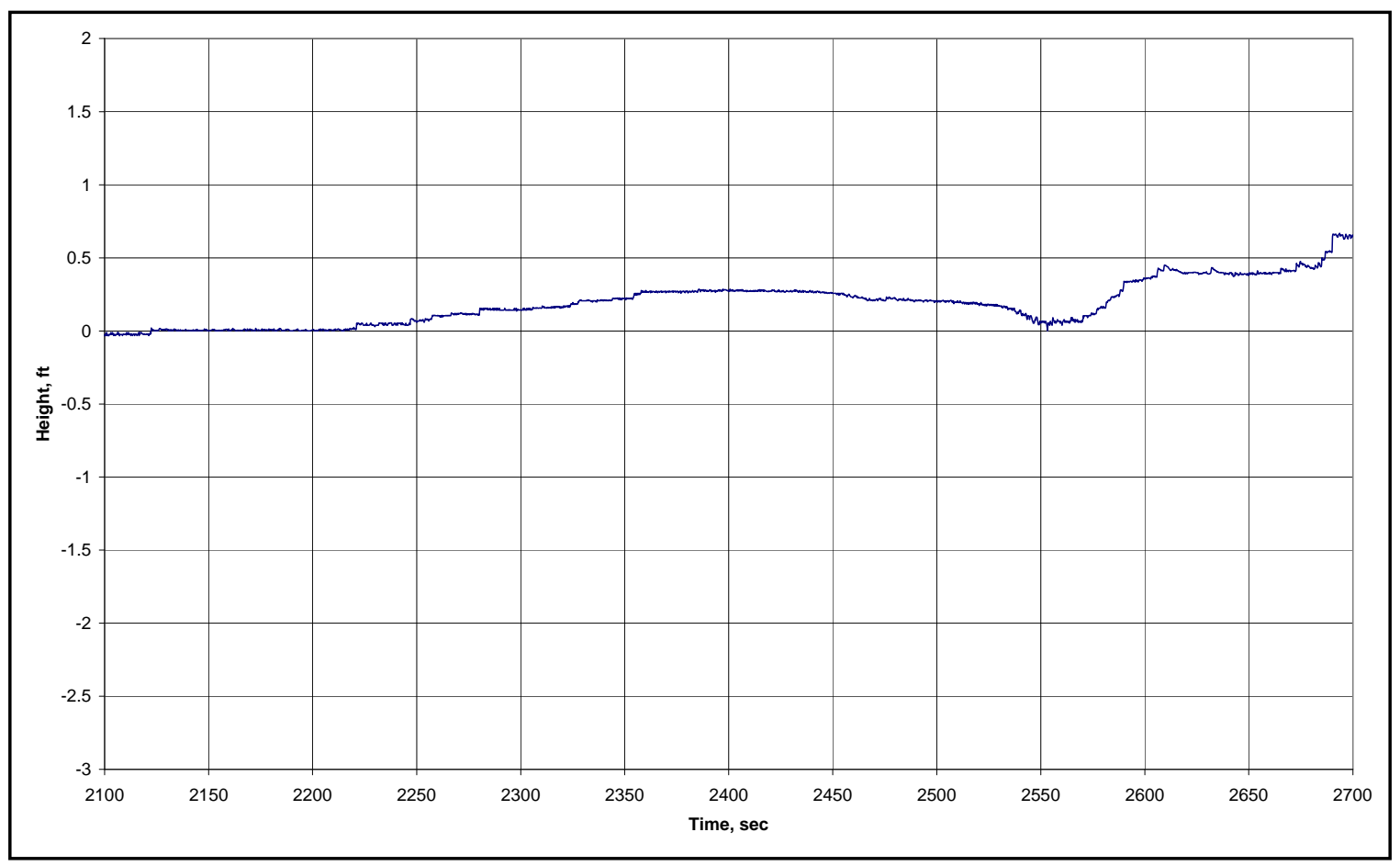

Figure C16. Condor, inbound, time 0 = 1700 EDT, 18 Sep 2005.

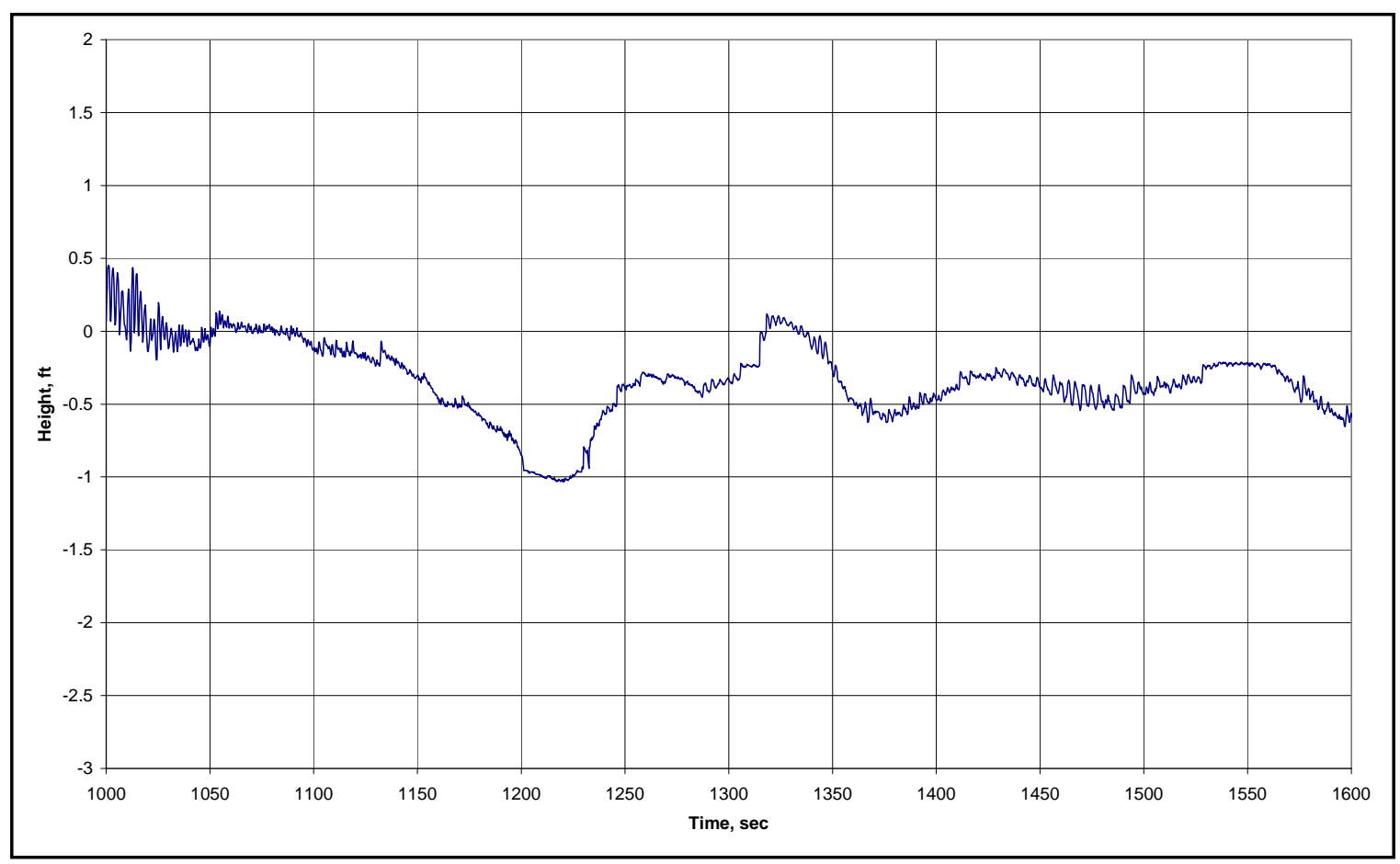

Figure C17. Victoria Bridge, inbound, time 0 = 2300 EDT, 18 Sep 2005. 


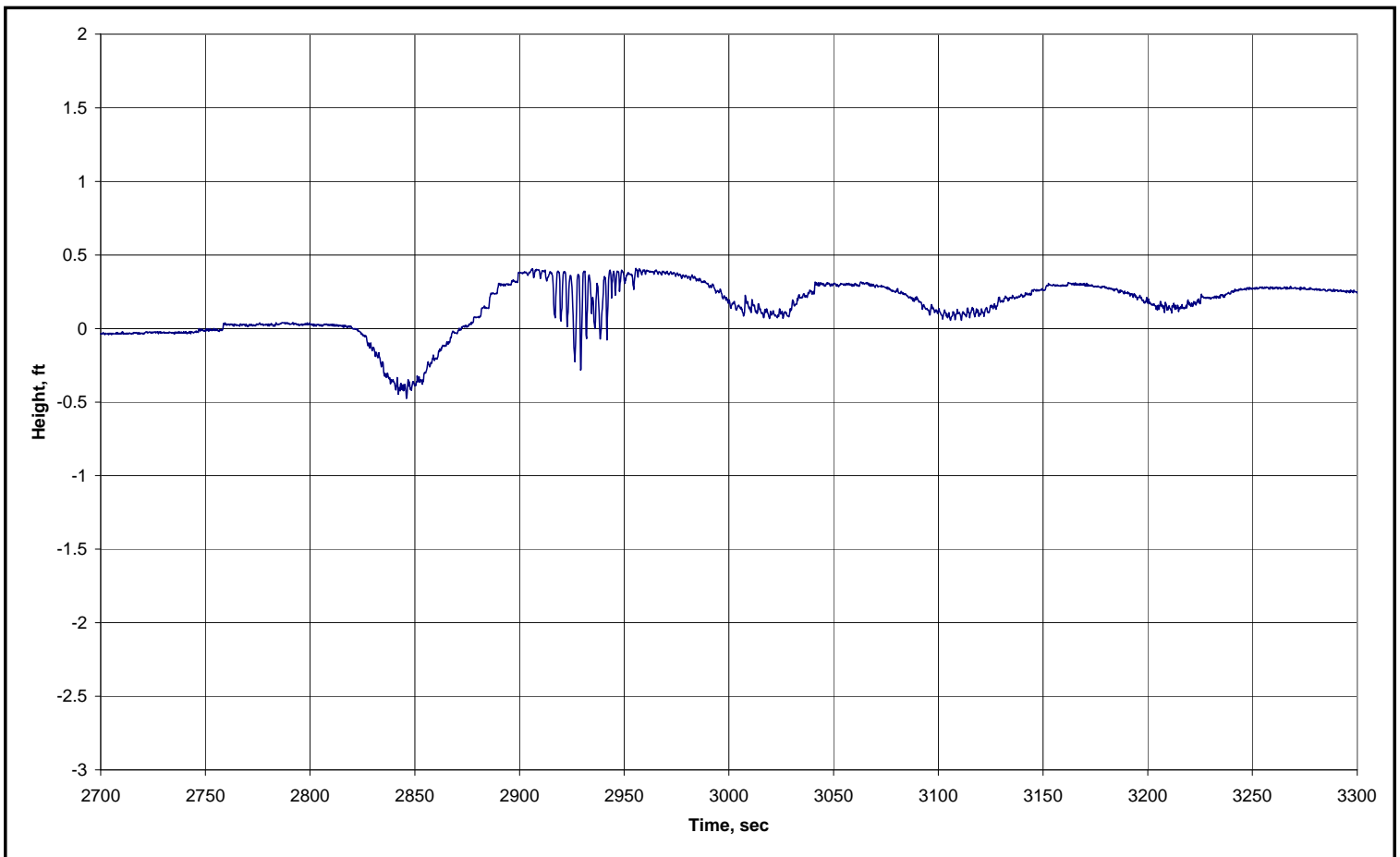

Figure C18. Kavo Alexandros II, inbound, time 0 = 0700 EDT, 19 Sep 2005.

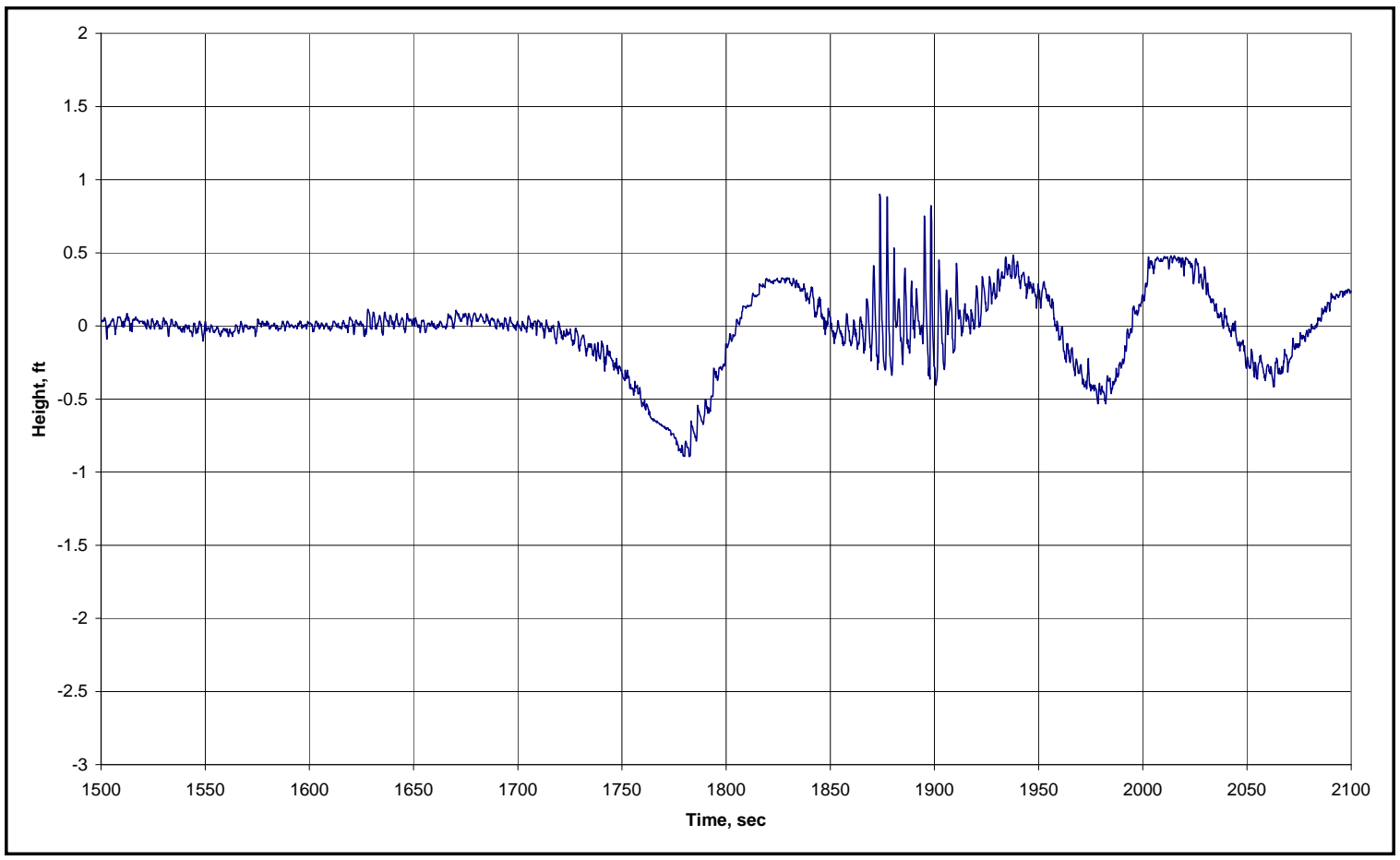

Figure C19. Angel Accord, inbound, time $0=1600$ EDT, 19 Sep 2005. 


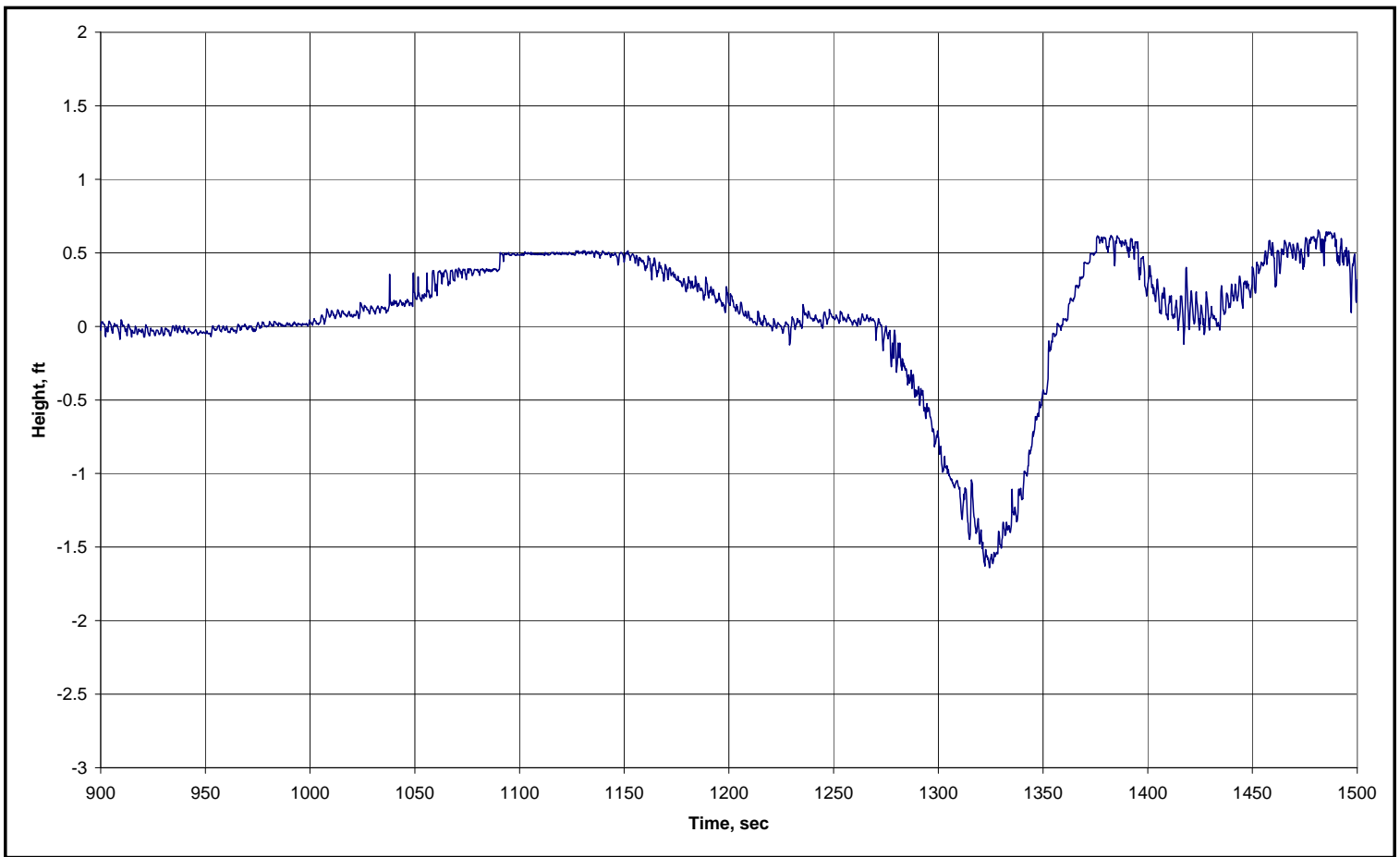

Figure C20. Mol Velocity, inbound, time 0 = 1700 EDT, 19 Sep 2005.

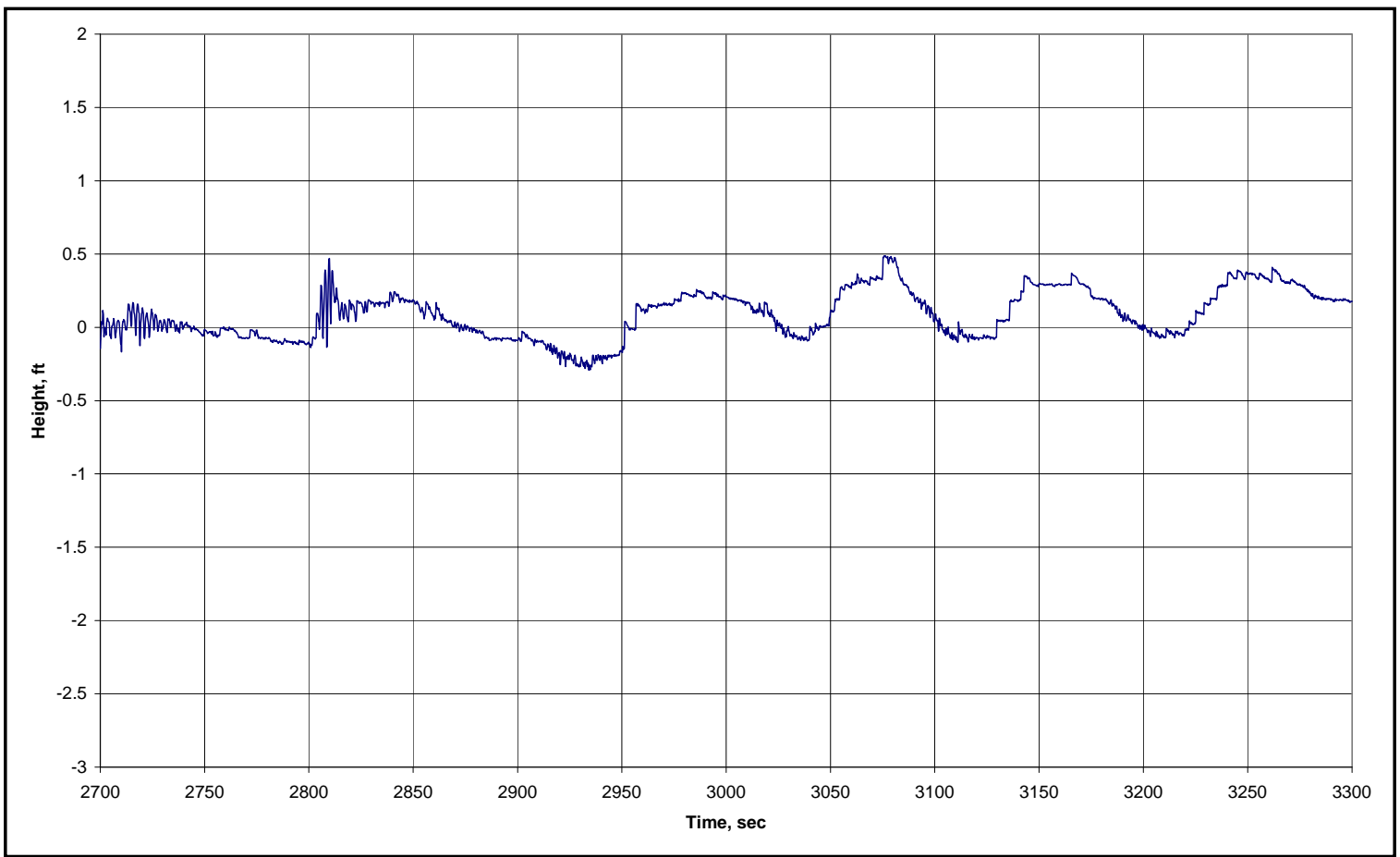

Figure C21. Borc, inbound, time $0=1800$ EDT, 19 Sep 2005. 


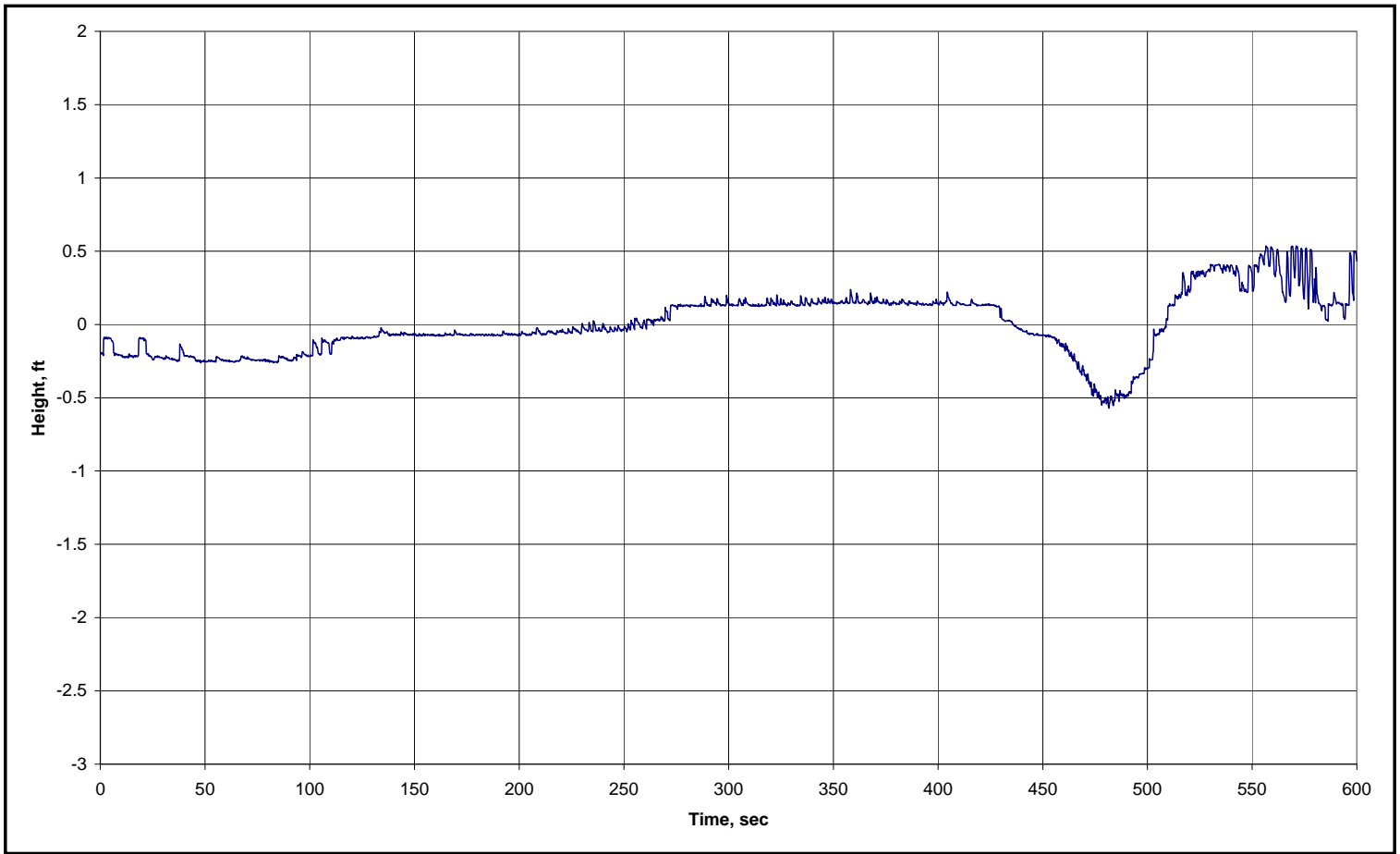

Figure C22. Jervis Bay, inbound, time 0 = 1800 EDT, 19 Sep 2005.

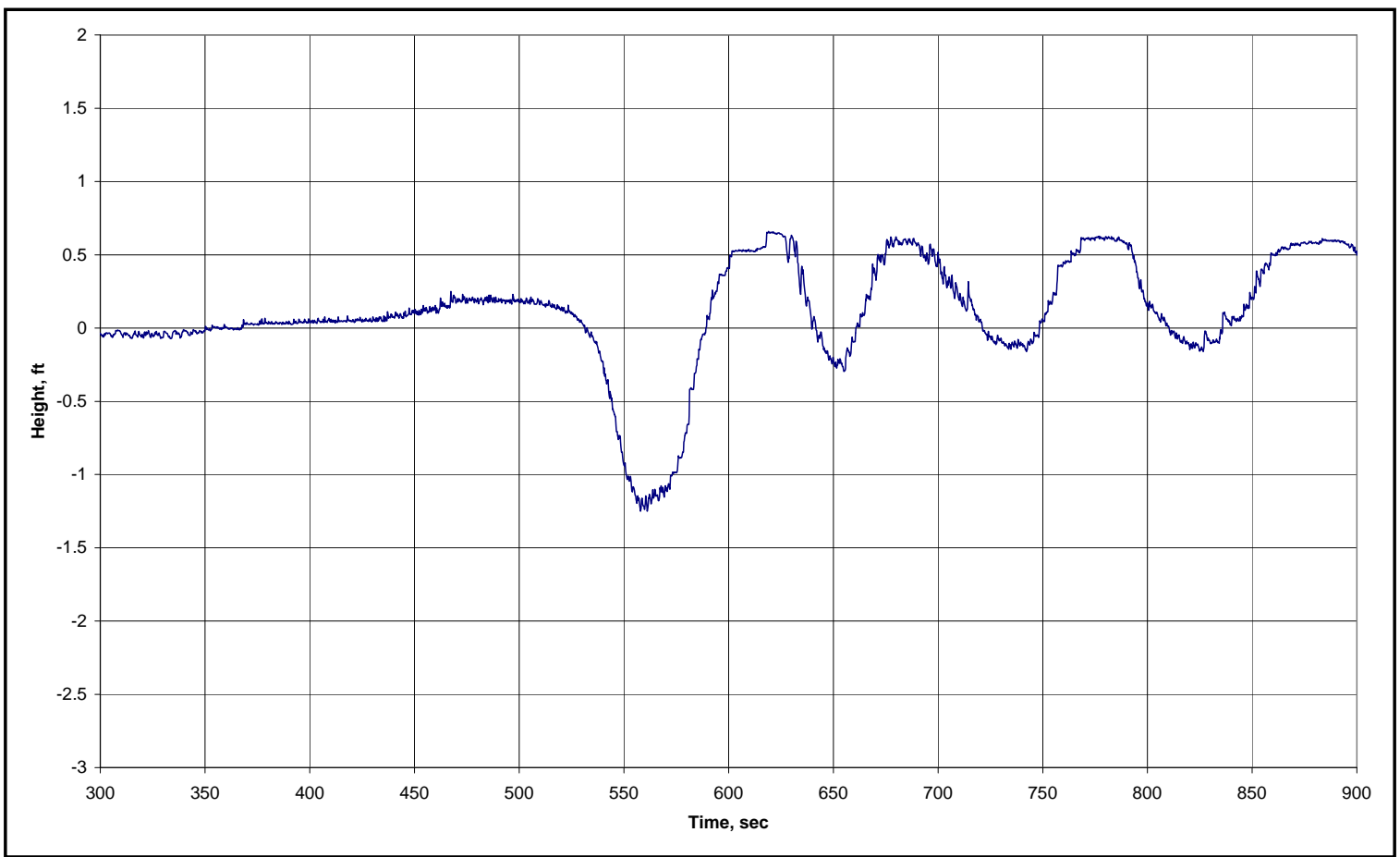

Figure C23. Ismini, inbound, time 0 = 2000 EDT, 19 Sep 2005. 


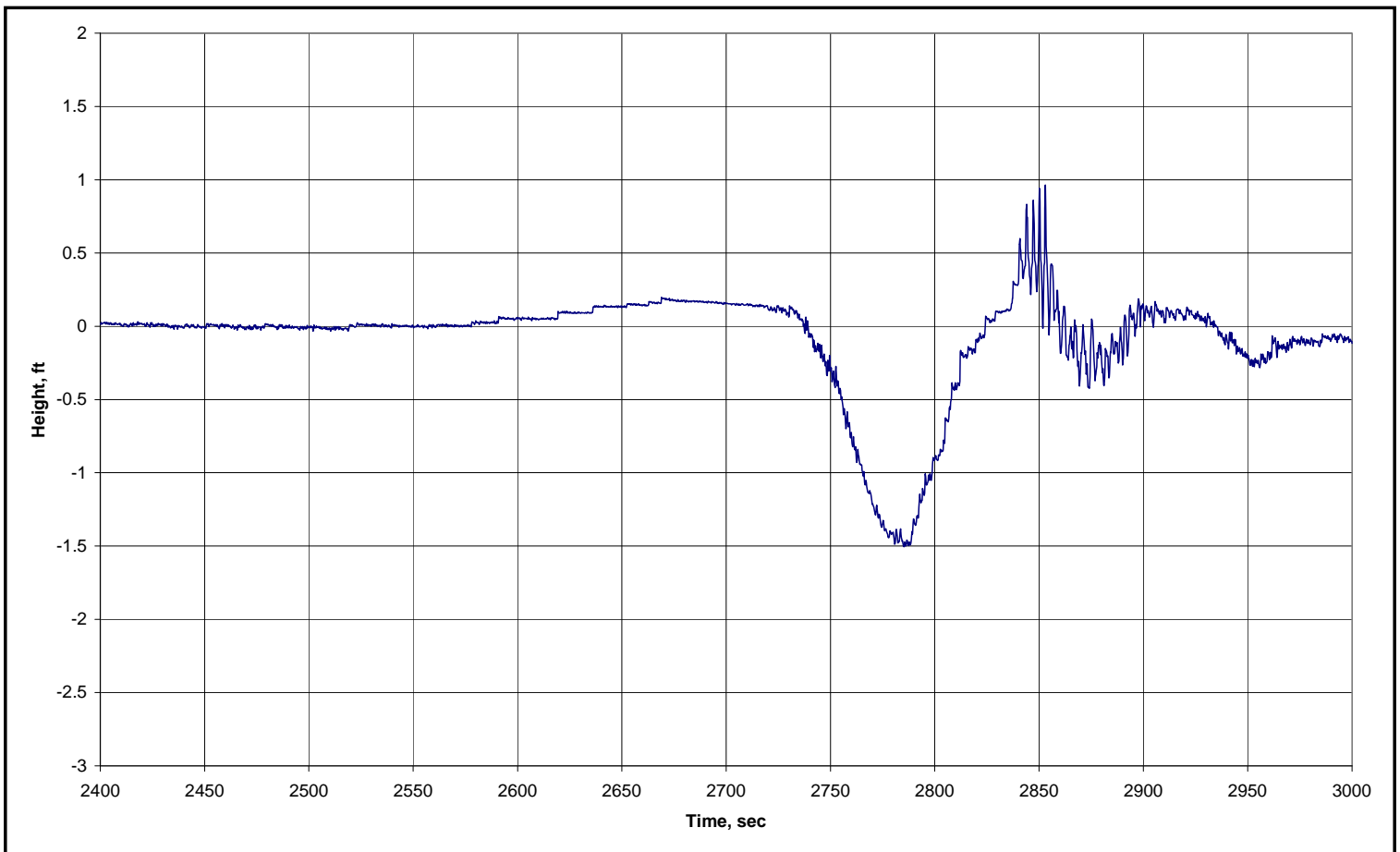

Figure C24. Stuttgart Express, inbound, time 0 = 2200 EDT, 19 Sep 2005.

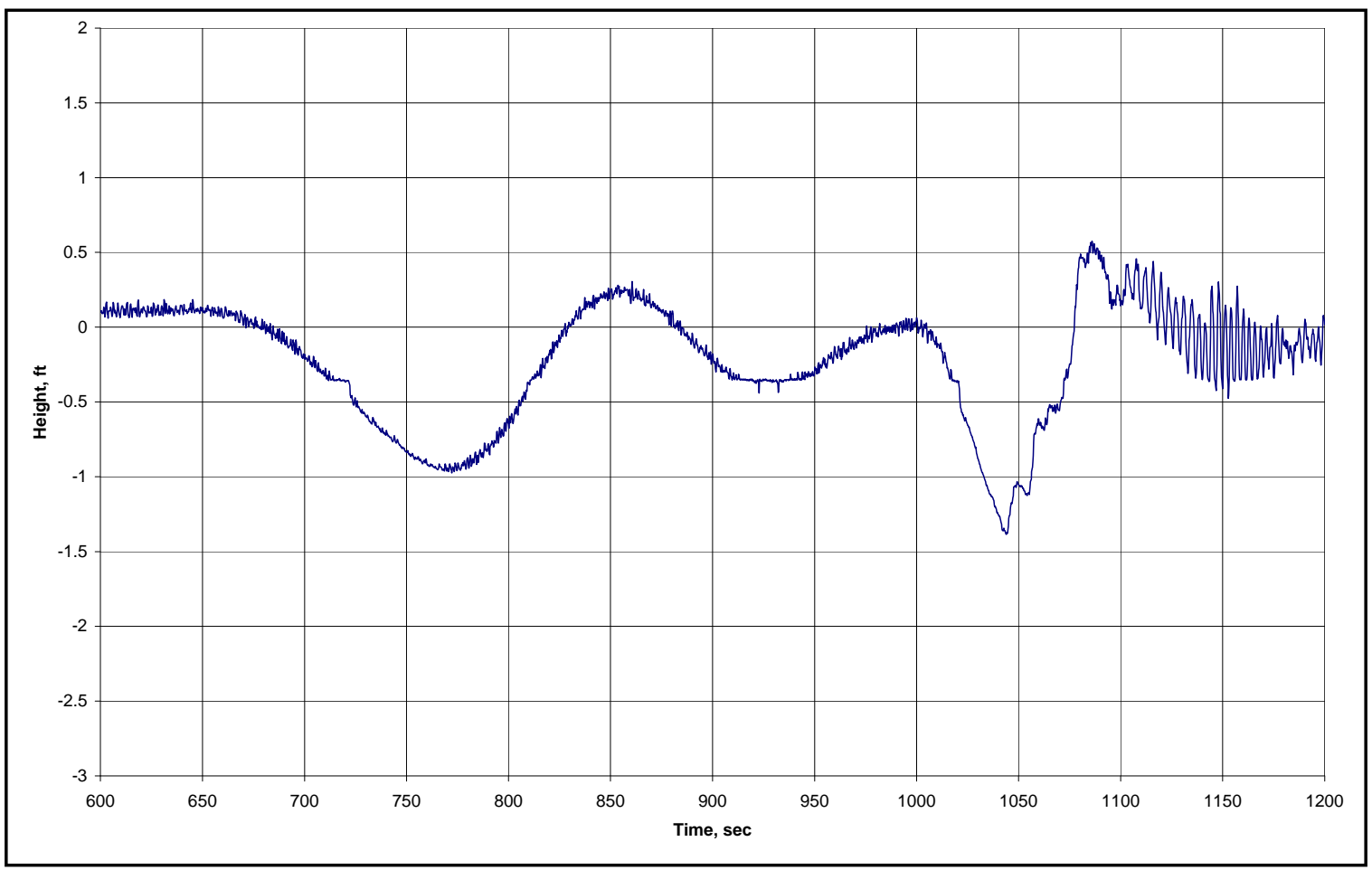

Figure C25. Talisman, outbound, time 0 = 1800 EDT, 16 Sep 2005. 


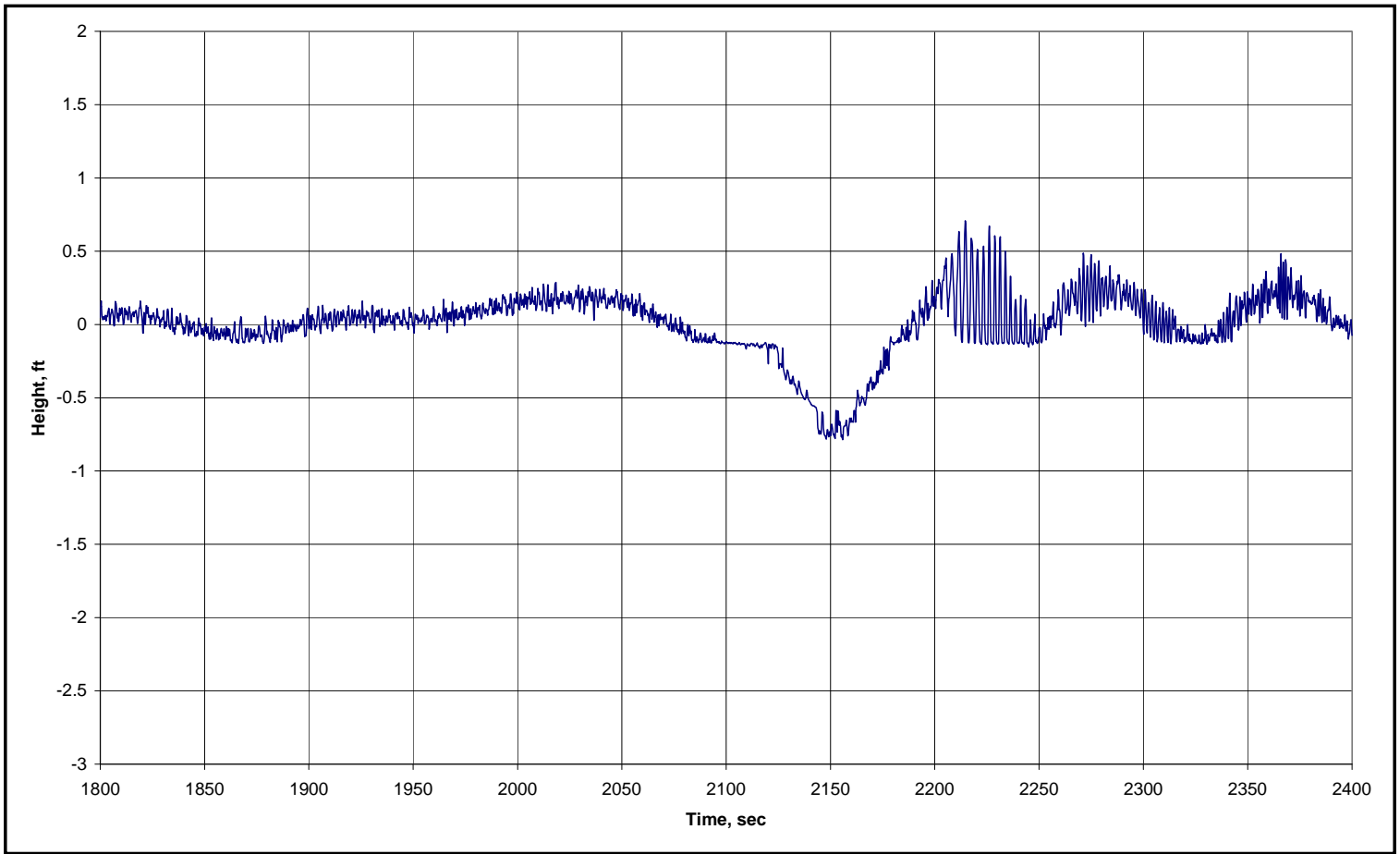

Figure C26. Jens Maersk, inbound, time 0 = 1800 EDT, 16 Sep 2005.

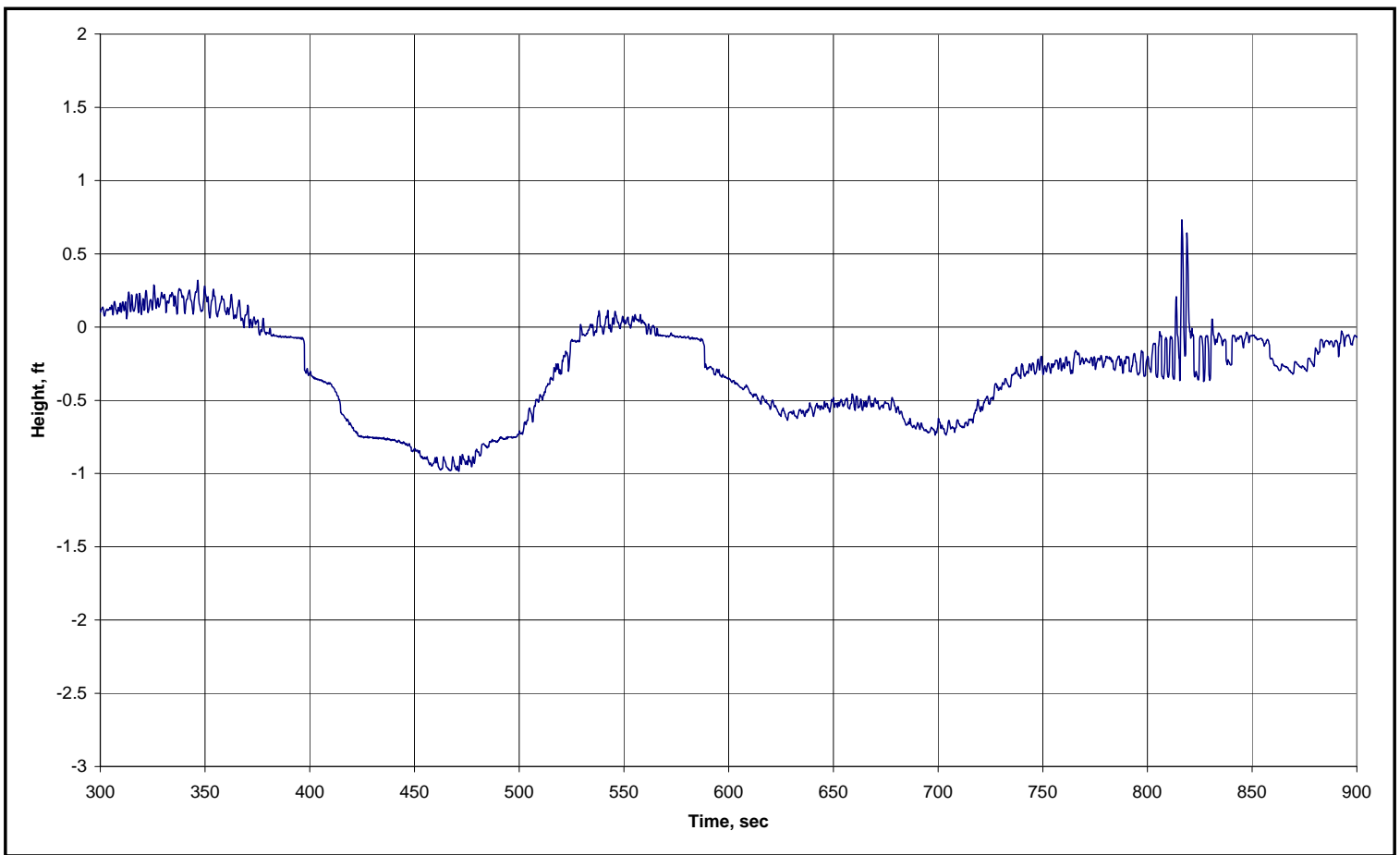

Figure C27. Xin Fang Cheng, outbound, time $0=2000$ EDT, 16 Sep 2005. 
ERDC/CHL TR-07-7

95

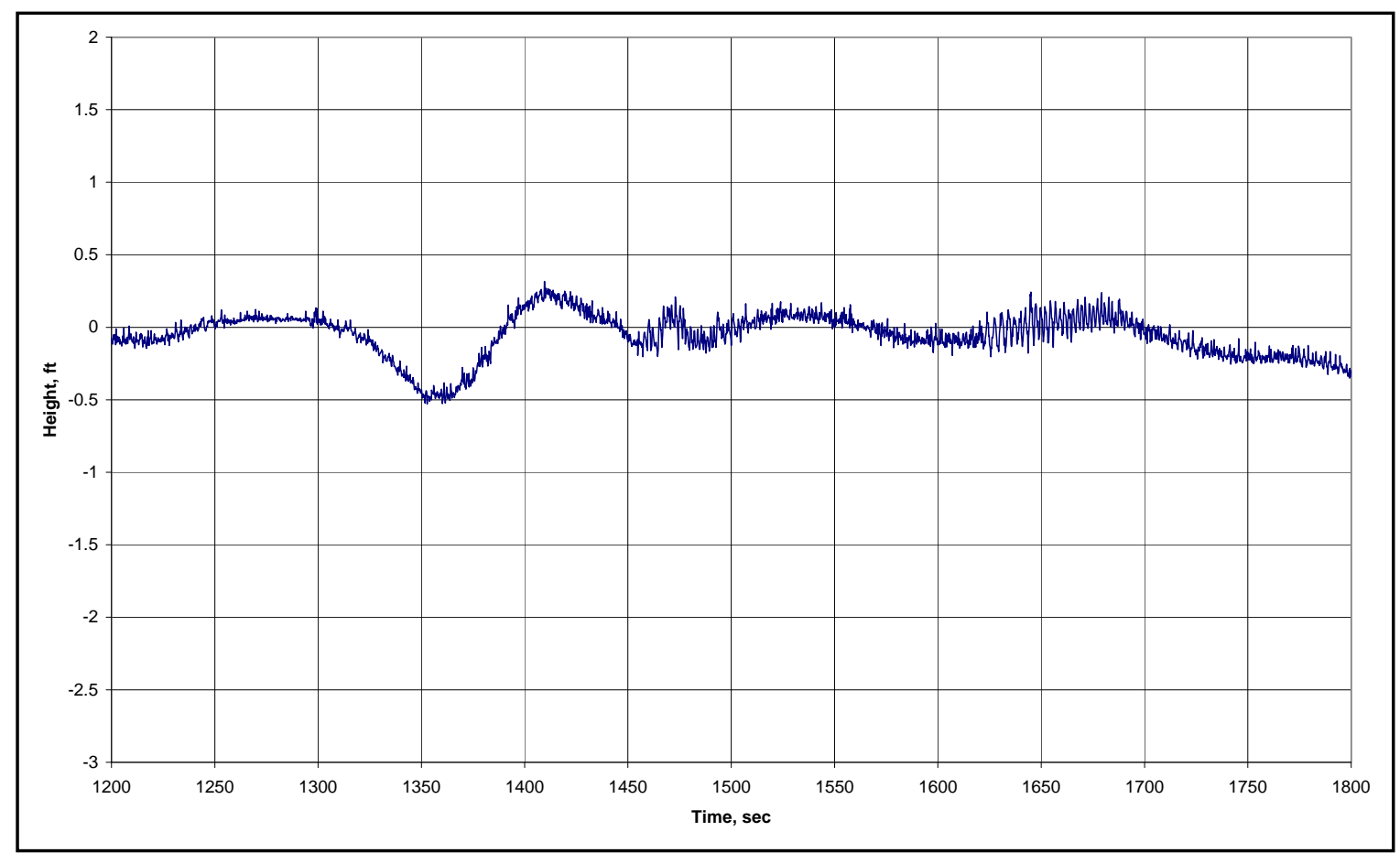

Figure C28. YM South, outbound, time 0 = 2100 EDT, 16 Sep 2005.

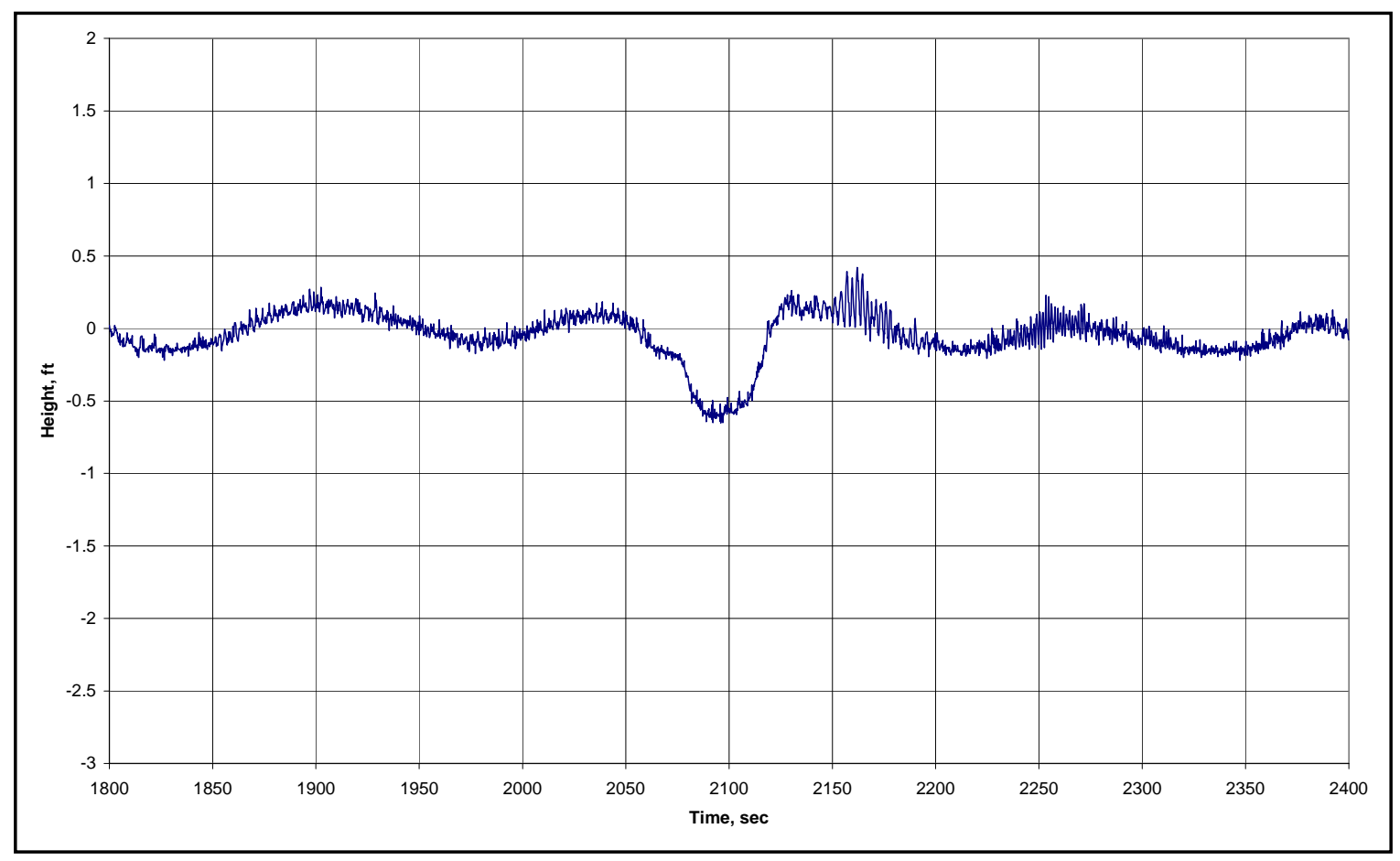

Figure C29. Maersk Garonne, outbound, time 0 = 2100 EDT, 16 Sep 2005. 


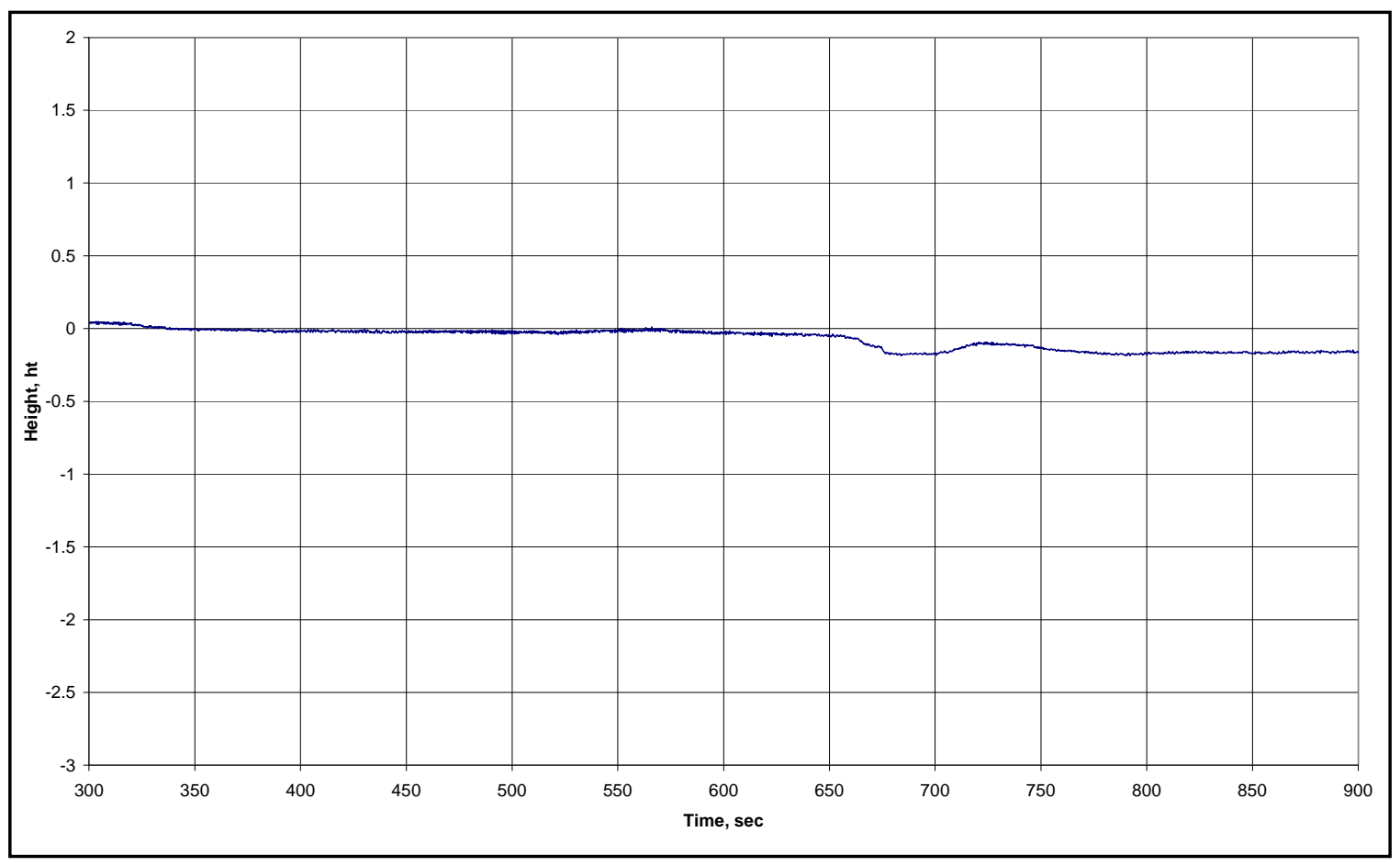

Figure C30. Star Drivanger, outbound, time 0 = 2200 EDT, 16 Sep 2005.

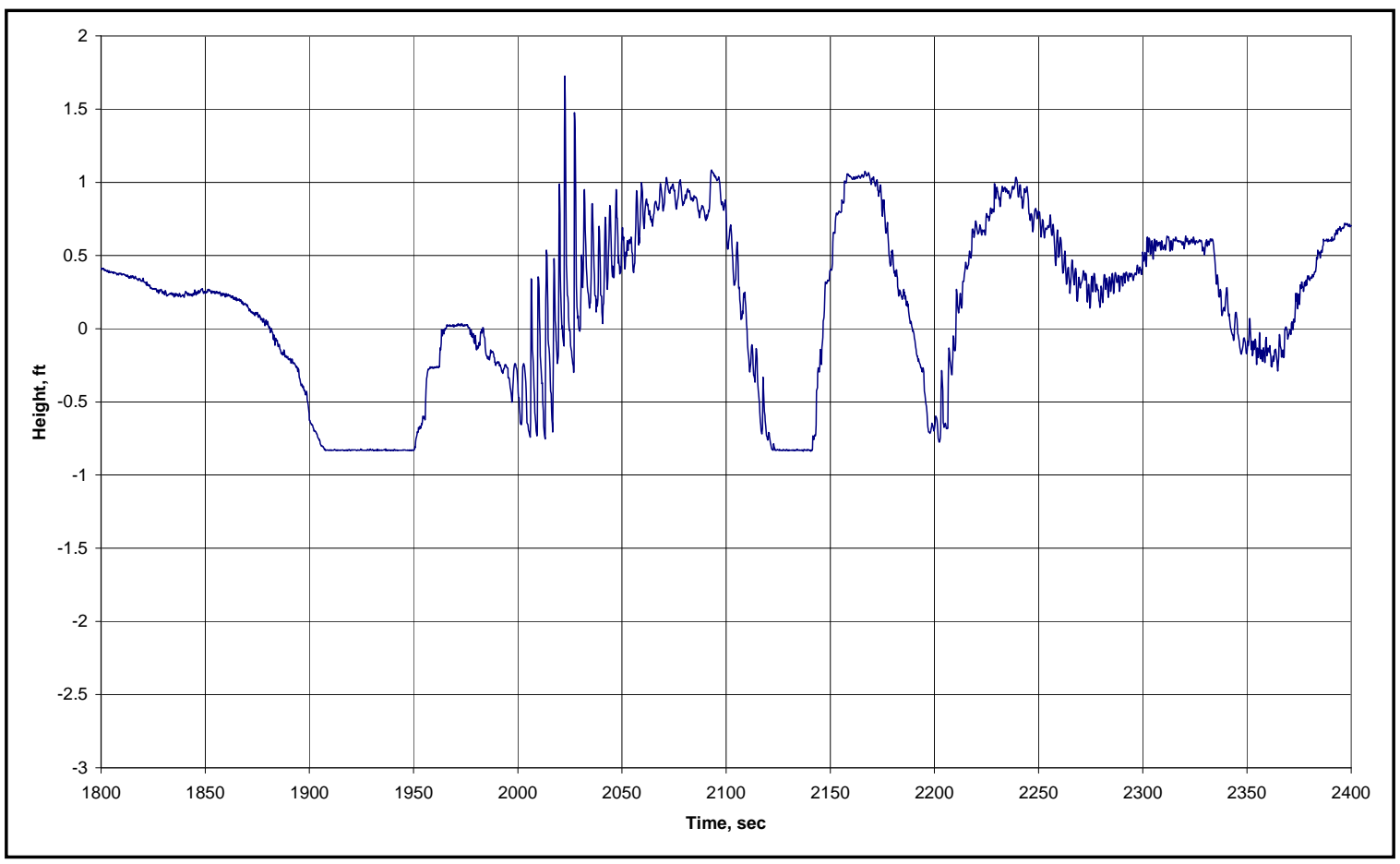

Figure C31. Leyla Kalkavan, outbound, time 0 = 0200 EDT, 17 Sep 2005. 


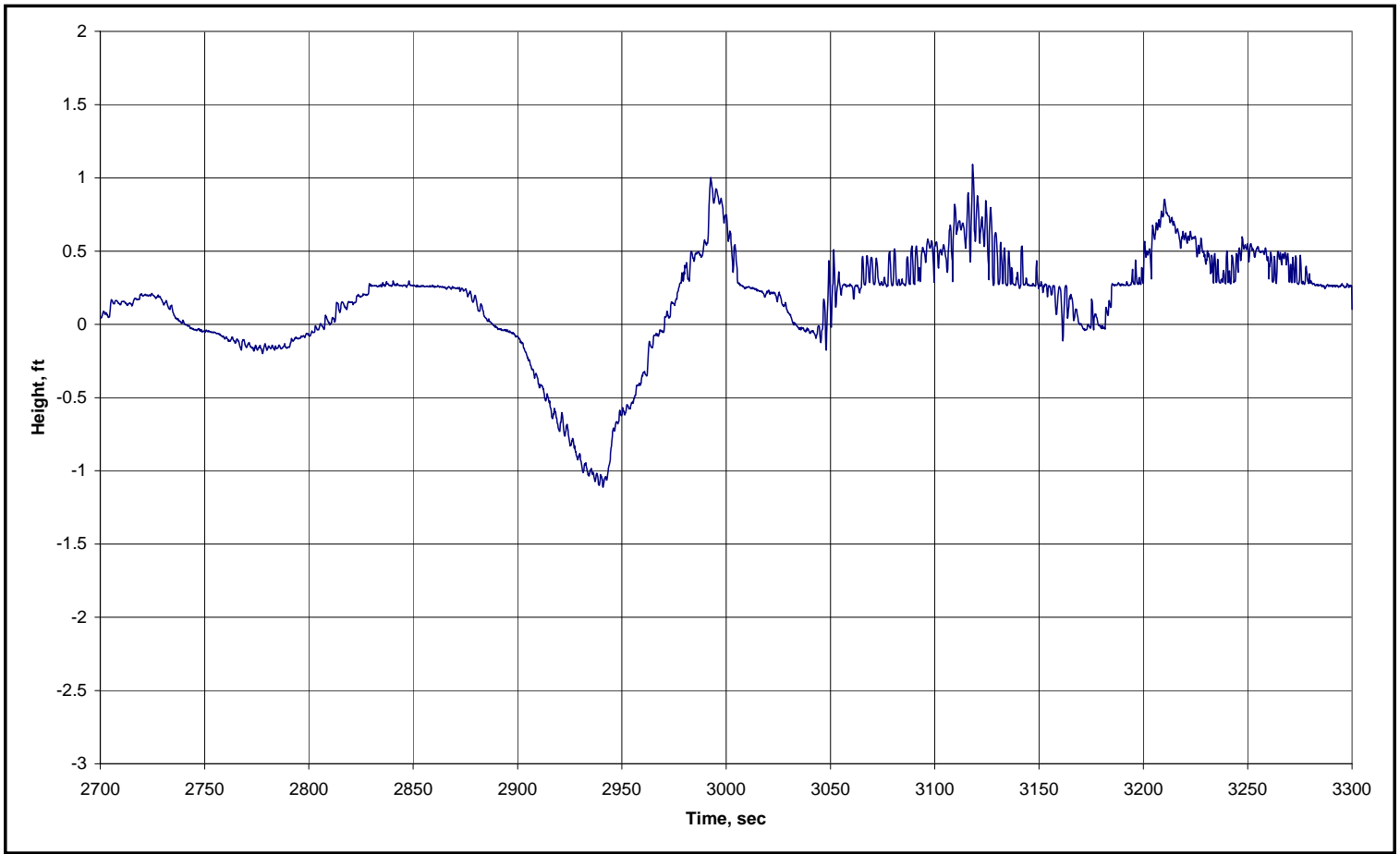

Figure C32. New York Express, outbound, time 0 = 0300 EDT, 17 Sep 2005.

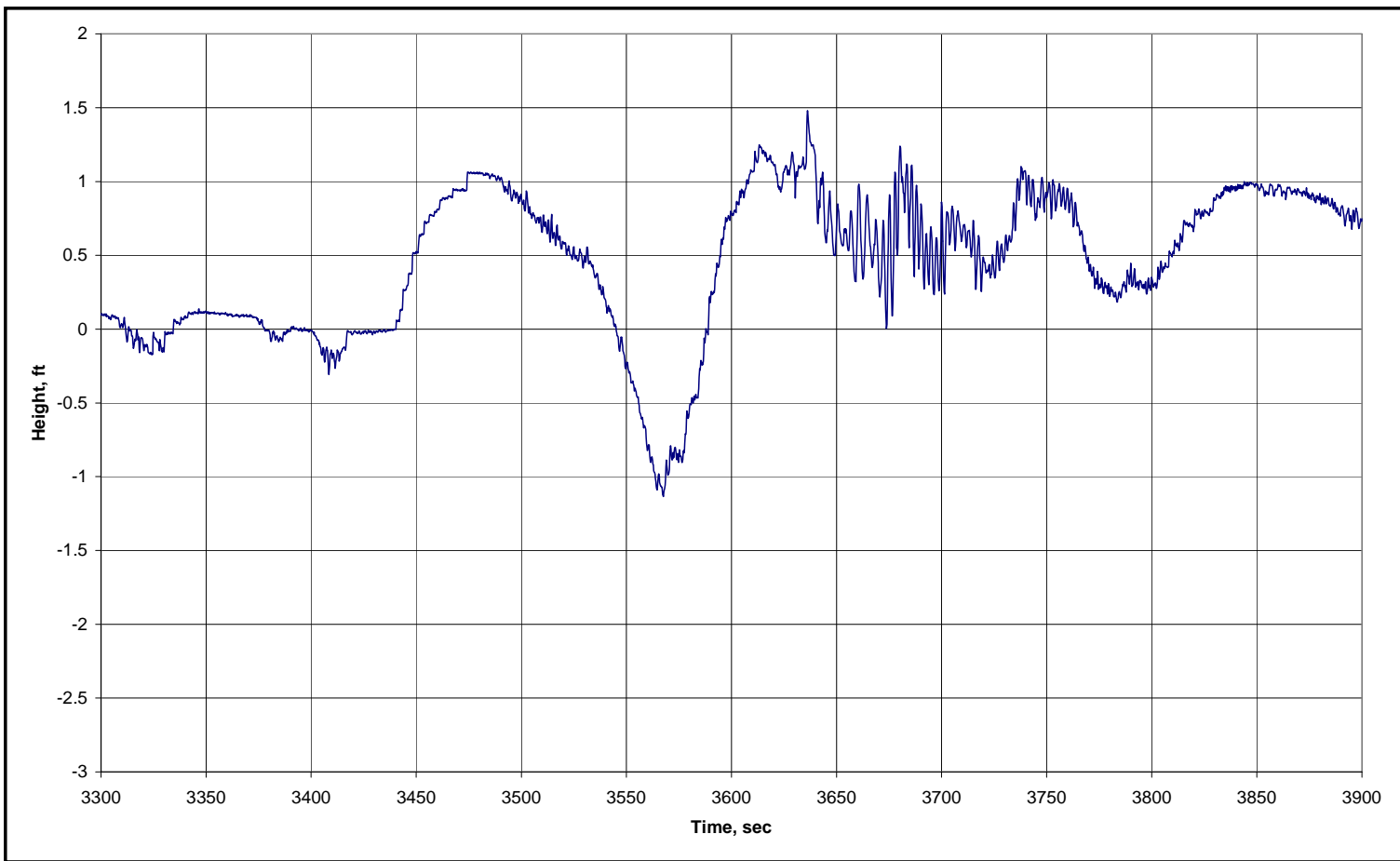

Figure C33. Star Florida, outbound, time 0 = 0300 EDT, 17 Sep 2005. 


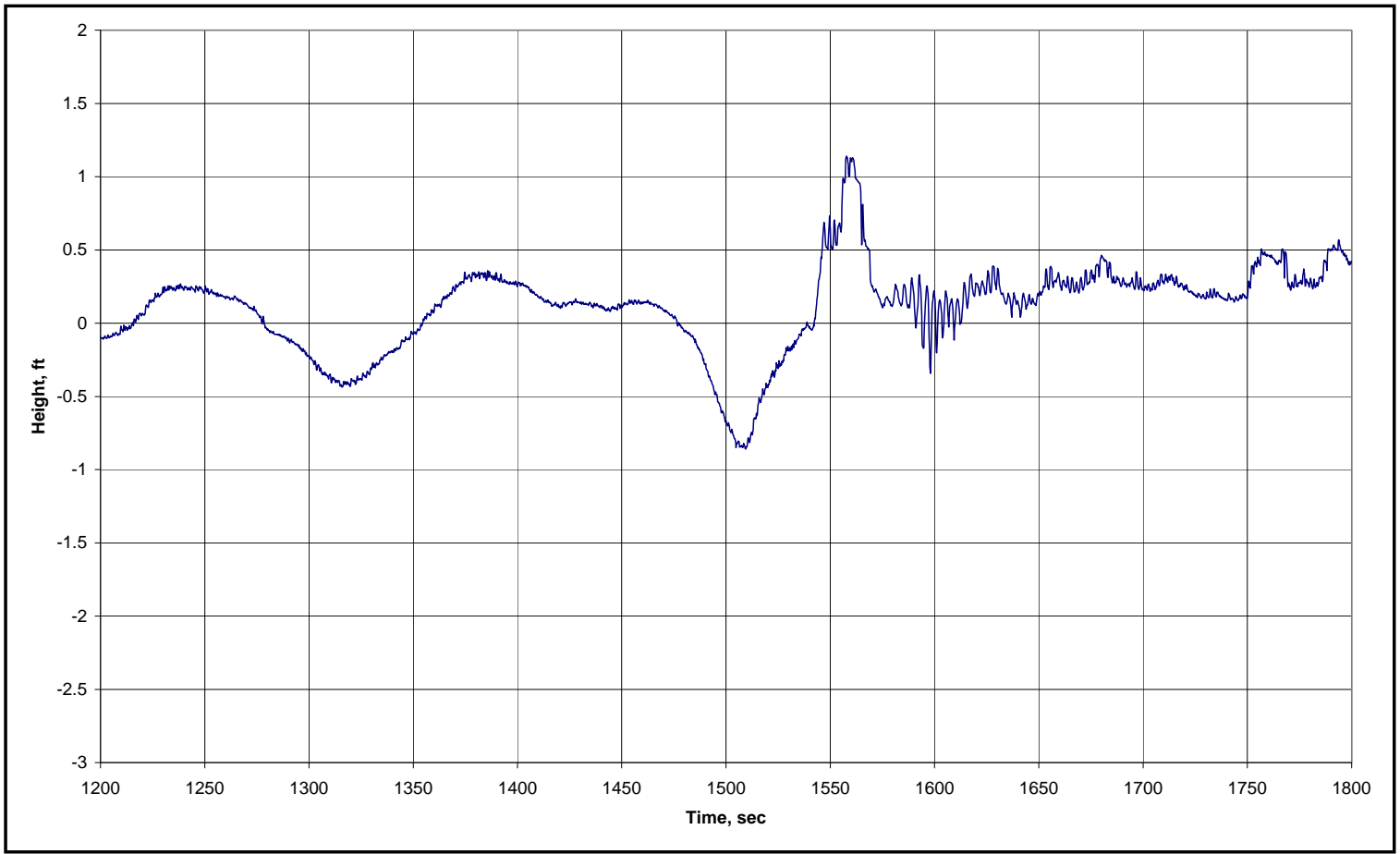

Figure C34. Jens Maersk, outbound, time 0 = 0300 EDT, 17 Sep 2005.

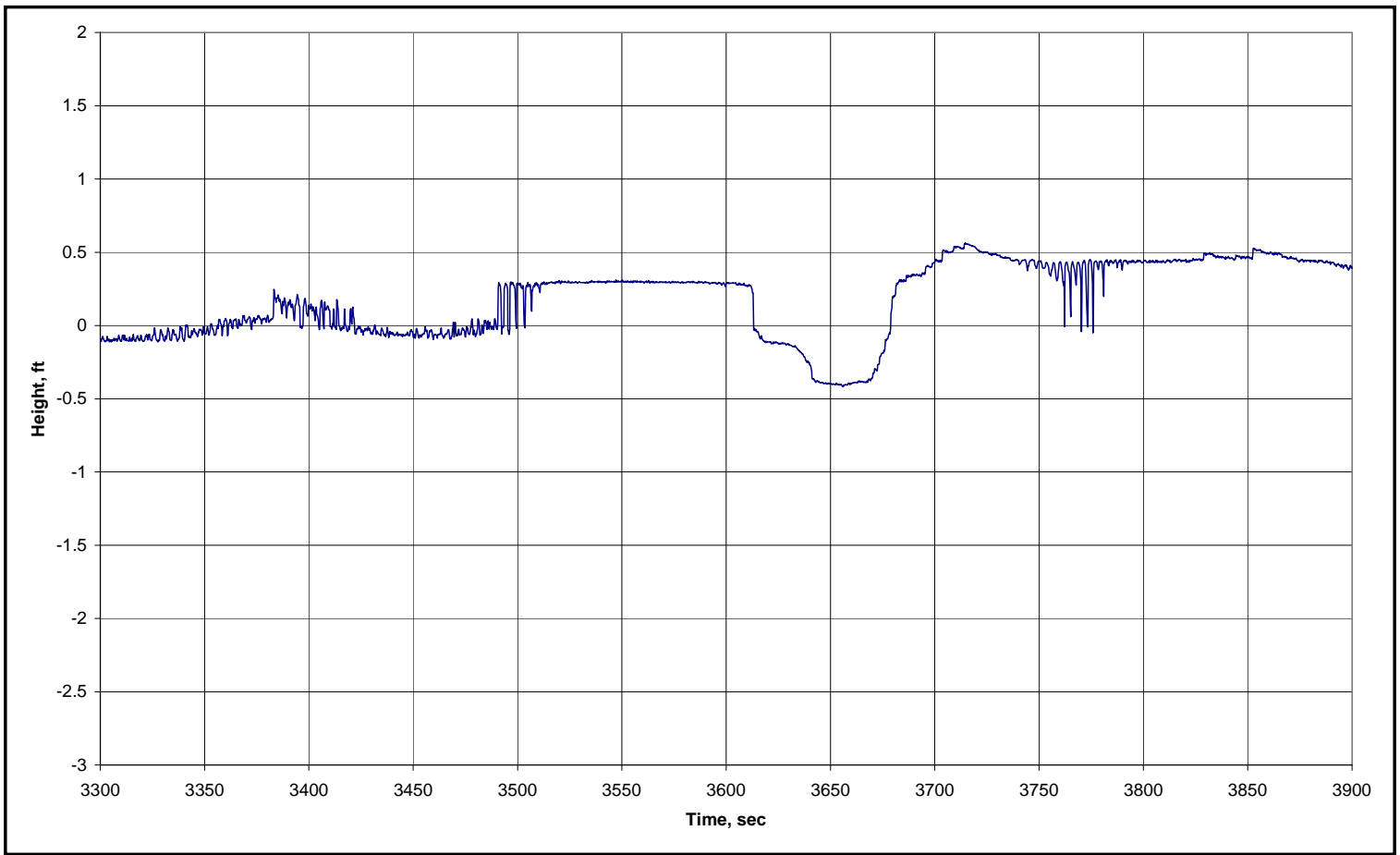

Figure C35. Kyriakoula, outbound, time 0 = 0500 EDT, 17 Sep 2005. 
ERDC/CHL TR-07-7

99

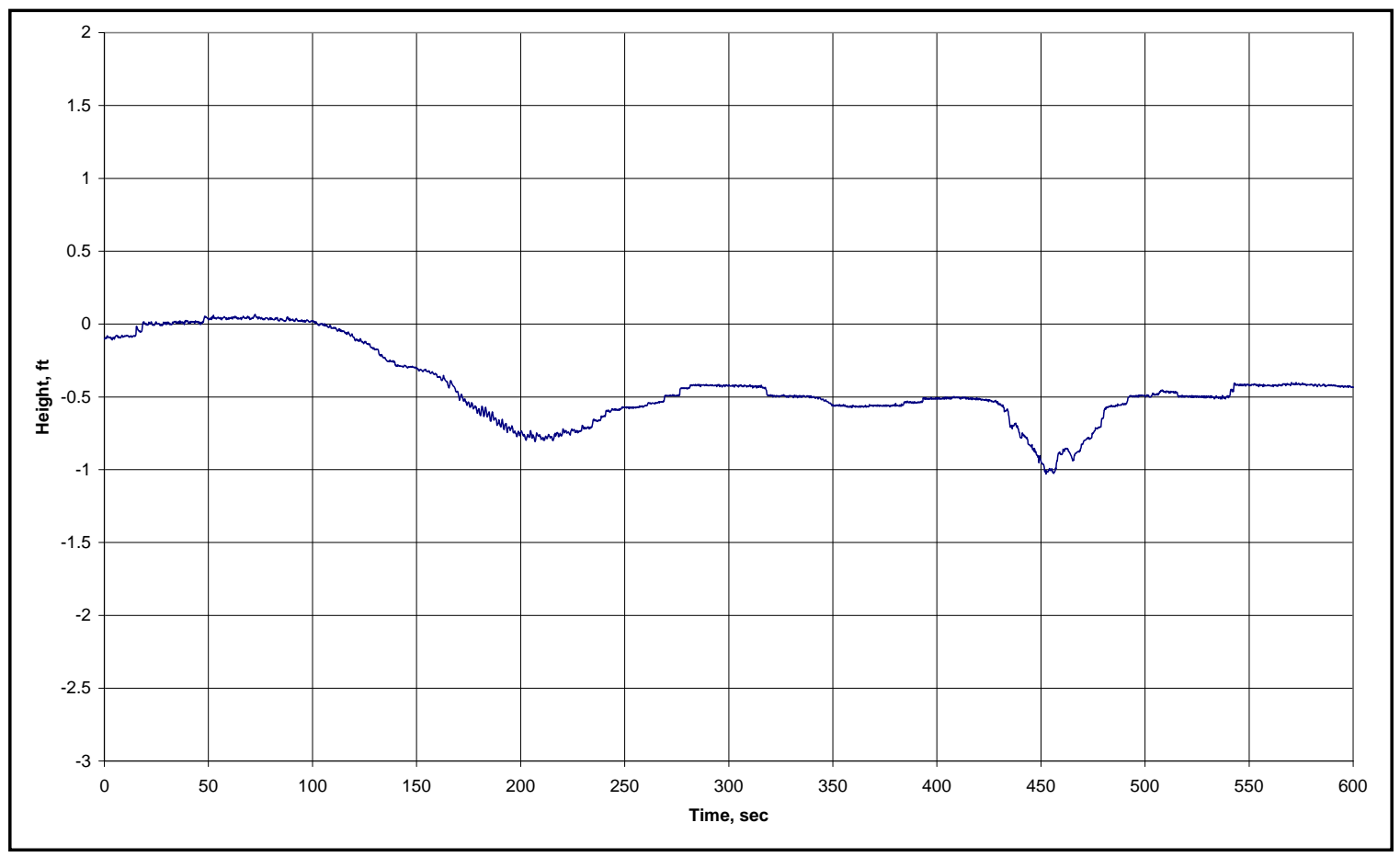

Figure C36. Sun Right, outbound, time 0 = 1000 EDT, 17 Sep 2005.

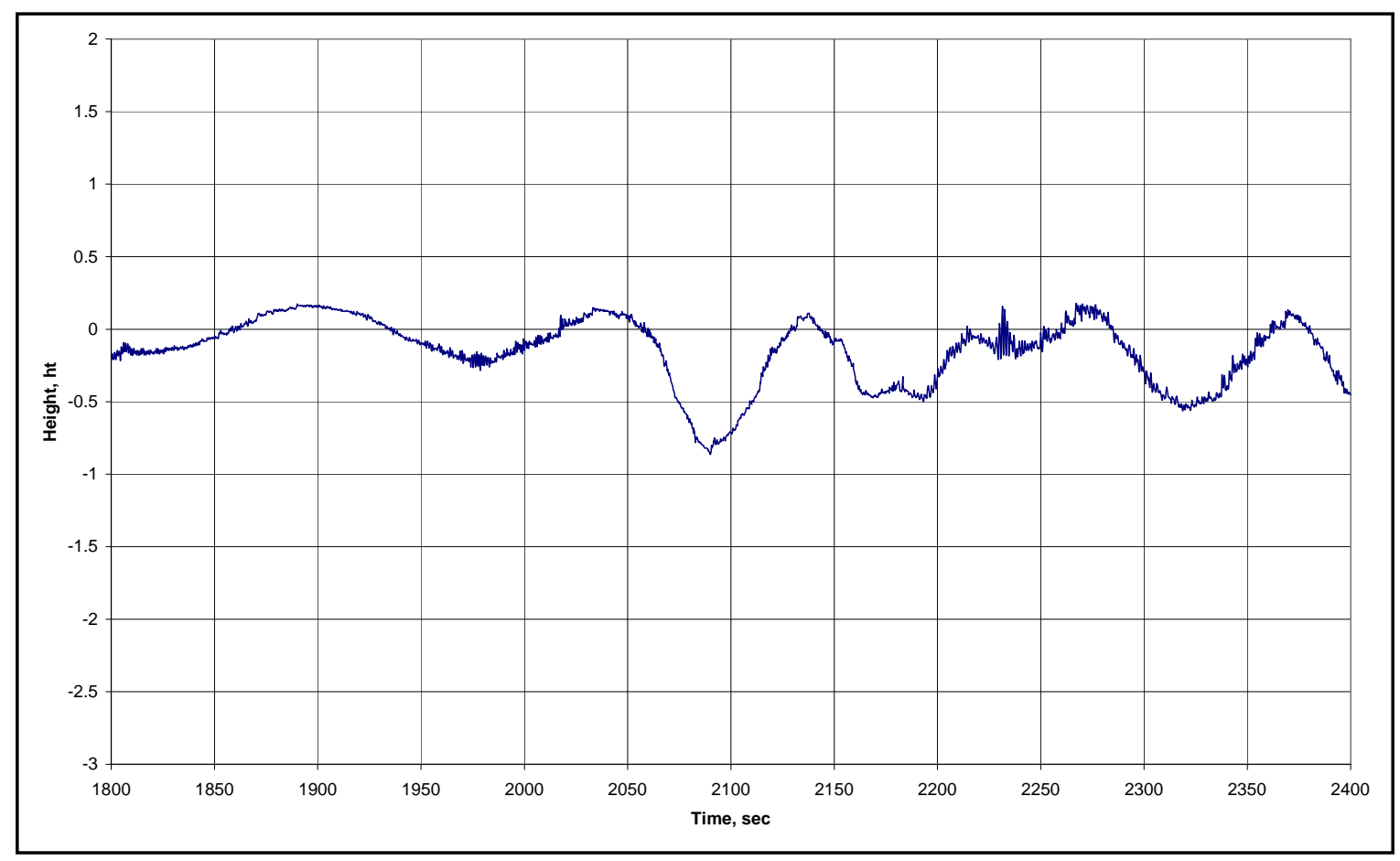

Figure C37. CMA CGM Potomoc, outbound, time 0 = 1200 EDT, 17 Sep 2005. 


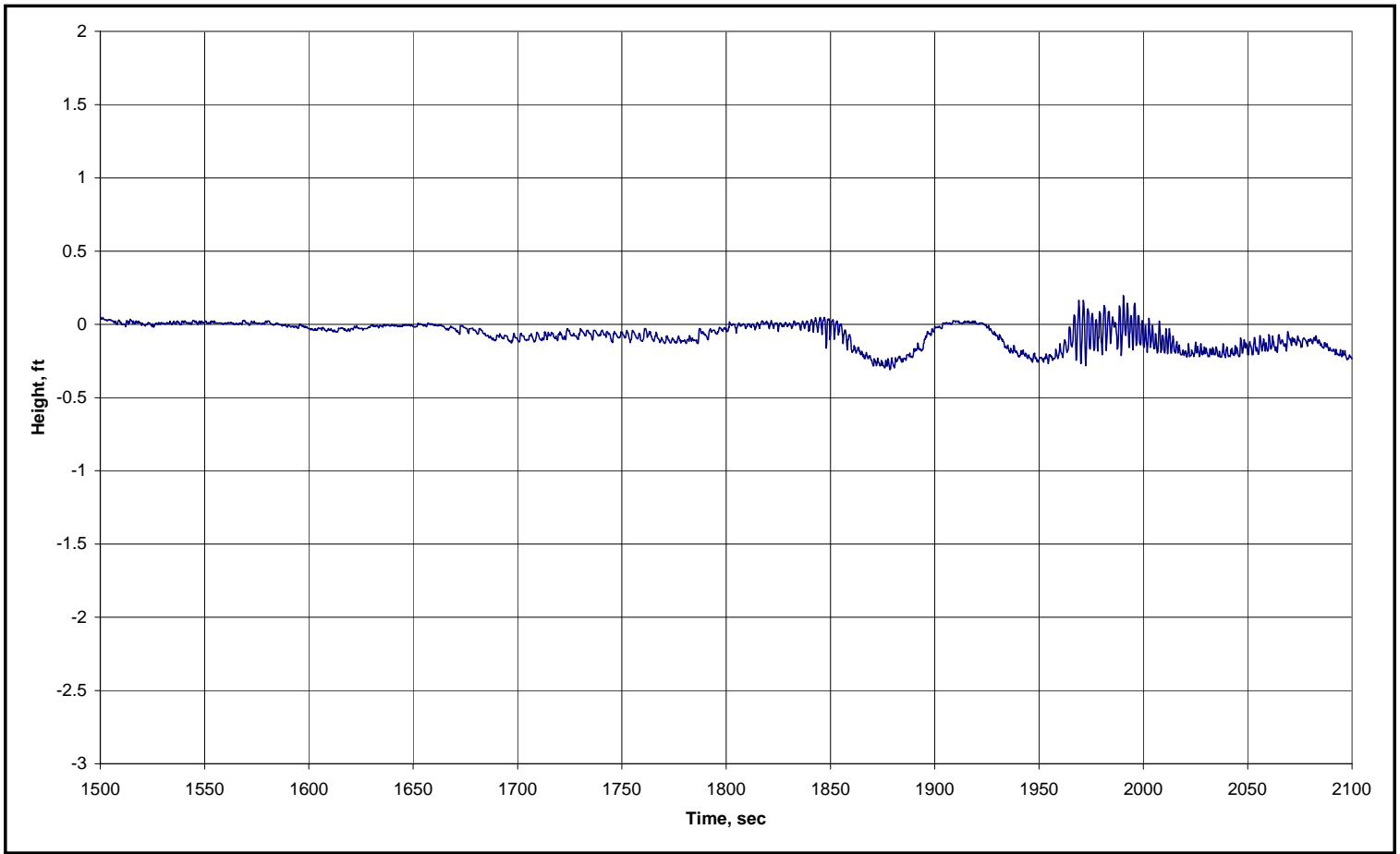

Figure C38. Flintereems, outbound, time $0=1300$ EDT, 17 Sep 2005.

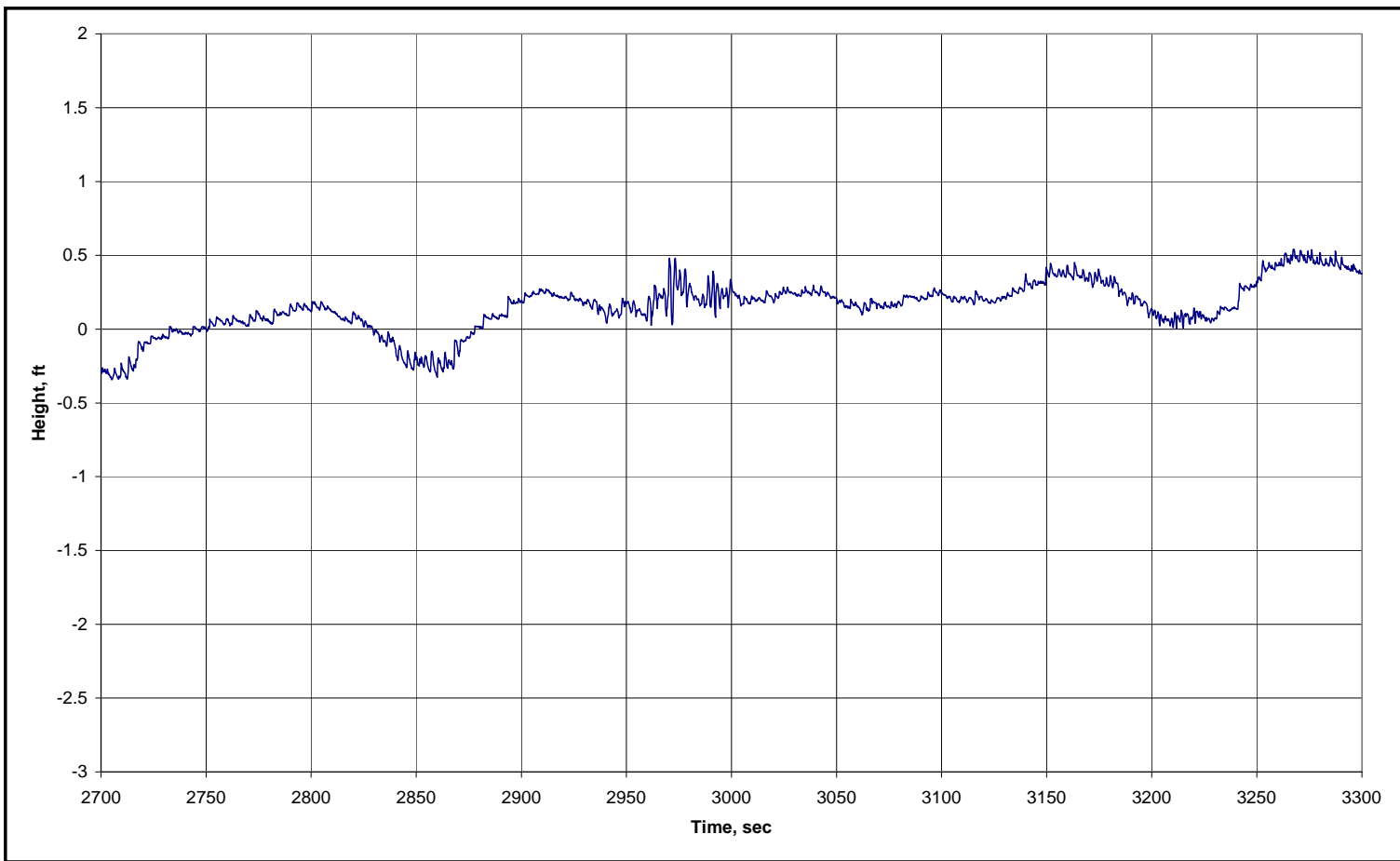

Figure C39. Kochnev, outbound, time 0 = 1500 EDT, 17 Sep 2005. 


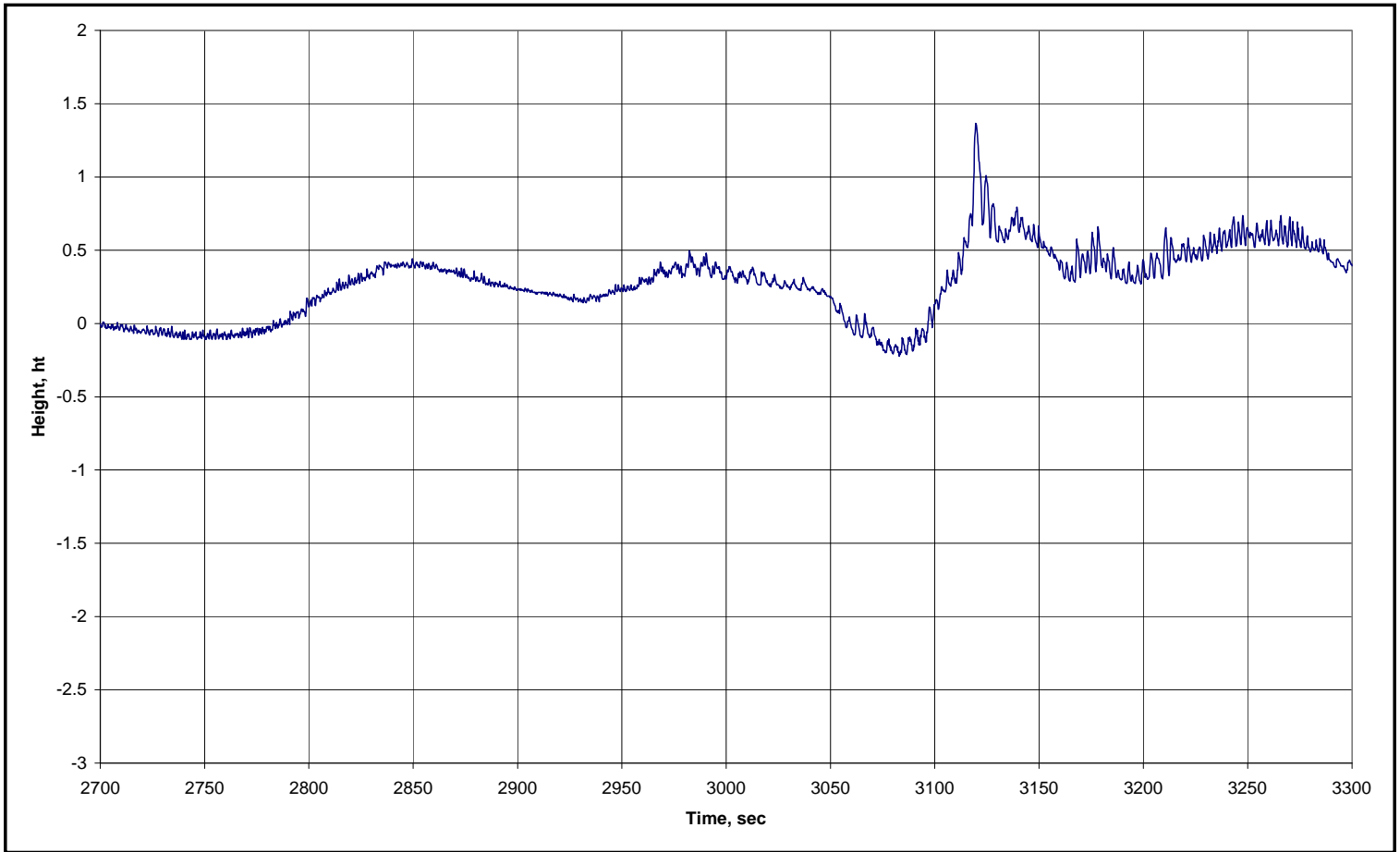

Figure C40. Jian An Cheng, outbound, time 0 = 1600 EDT, 17 Sep 2005.

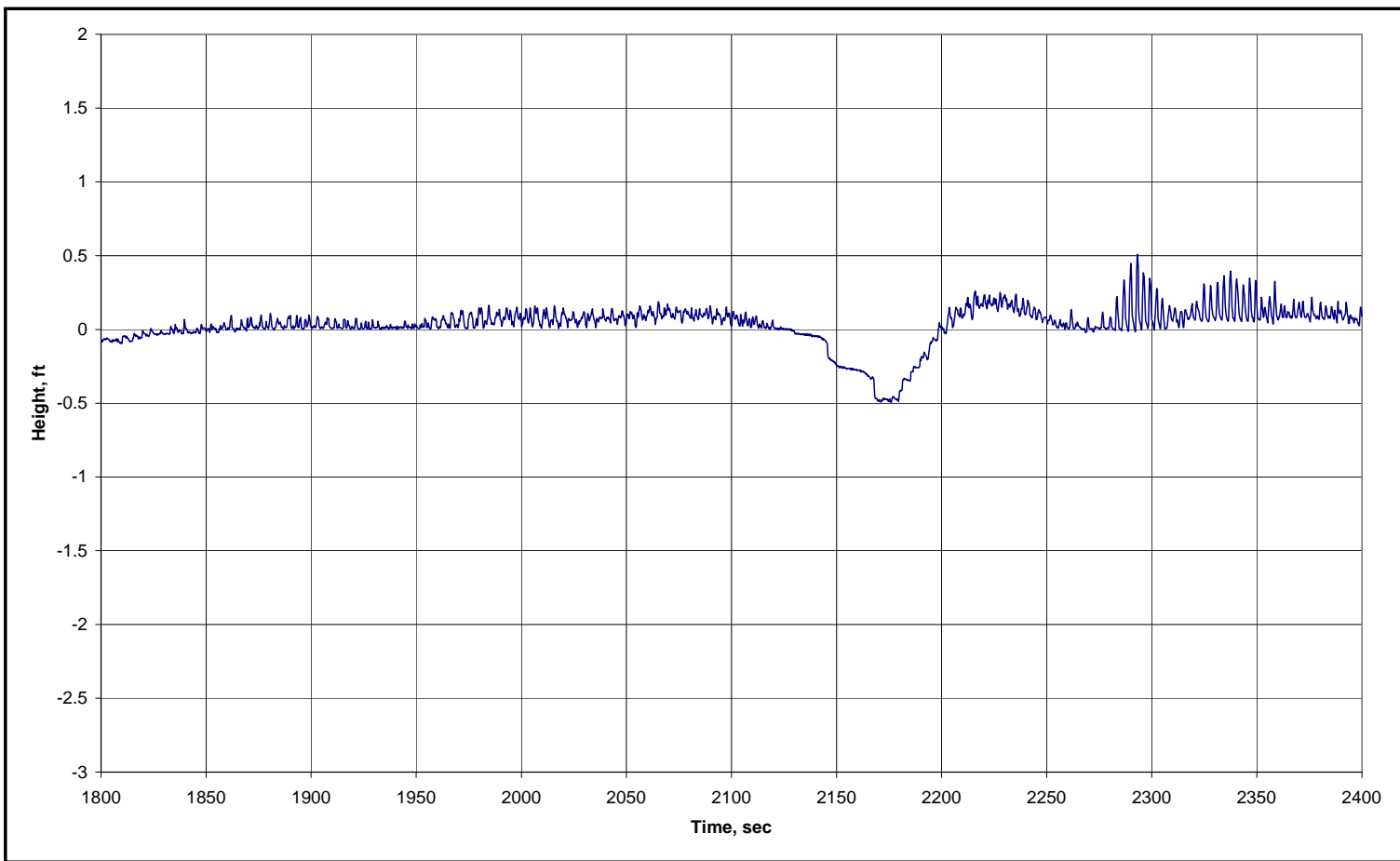

Figure C41. Mol Elbe, outbound, time 0 = 2000 EDT, 17 Sep 2005. 


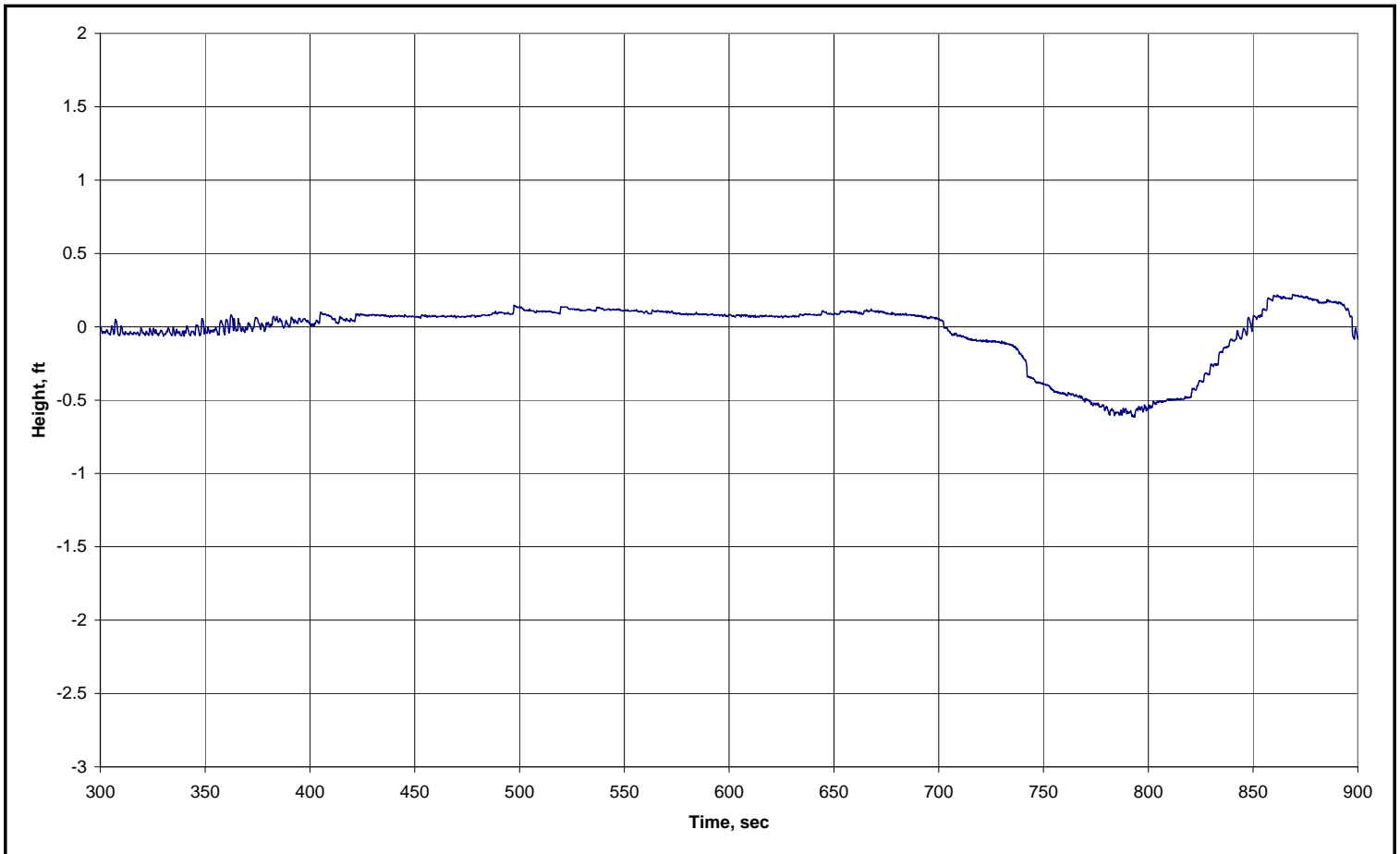

Figure C42. MSC Christina, outbound, time 0 = 2100 EDT, 17 Sep 2005.

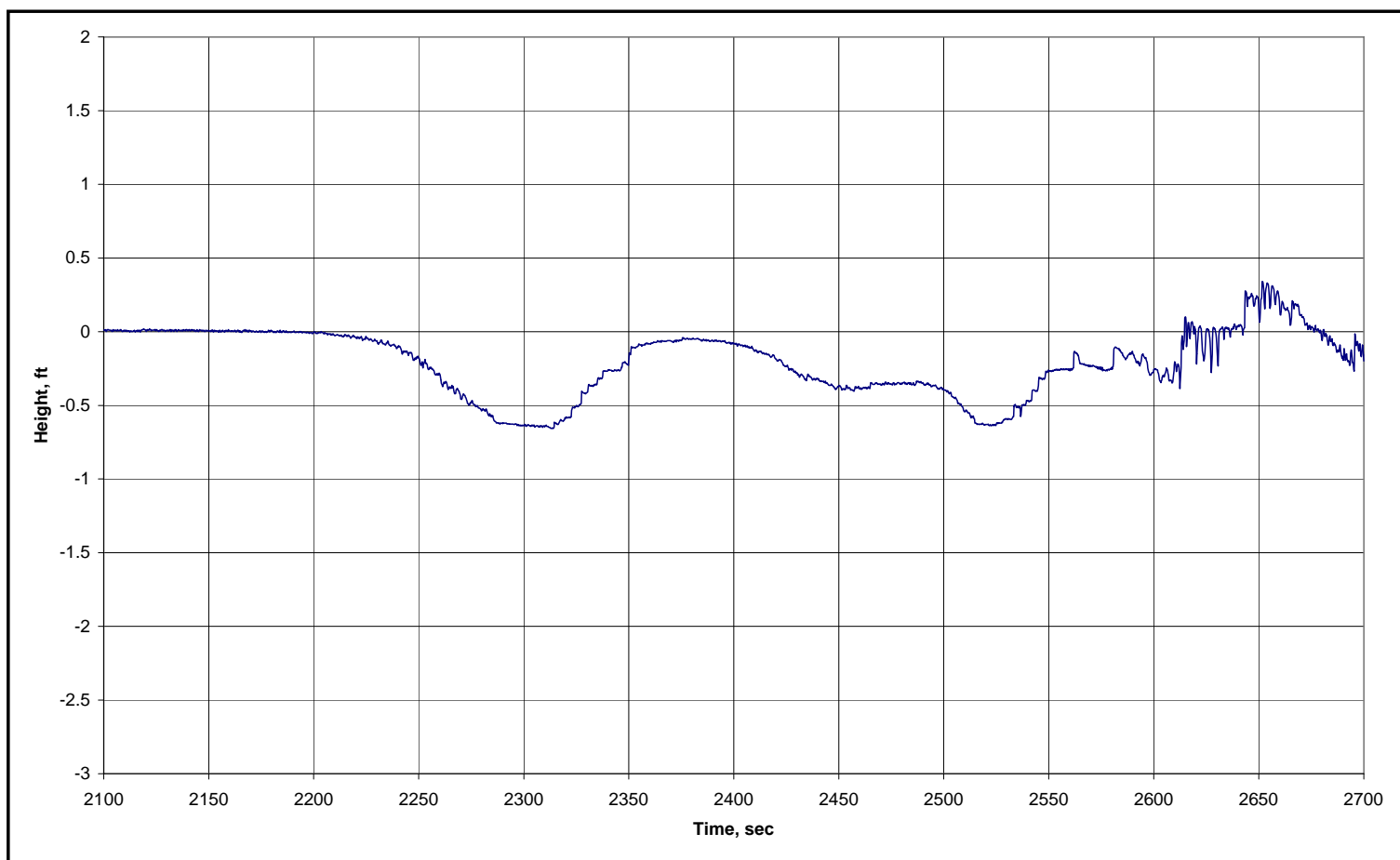

Figure C43. Zim Israel, outbound, time 0 = 2200 EDT, 17 Sep 2005. 


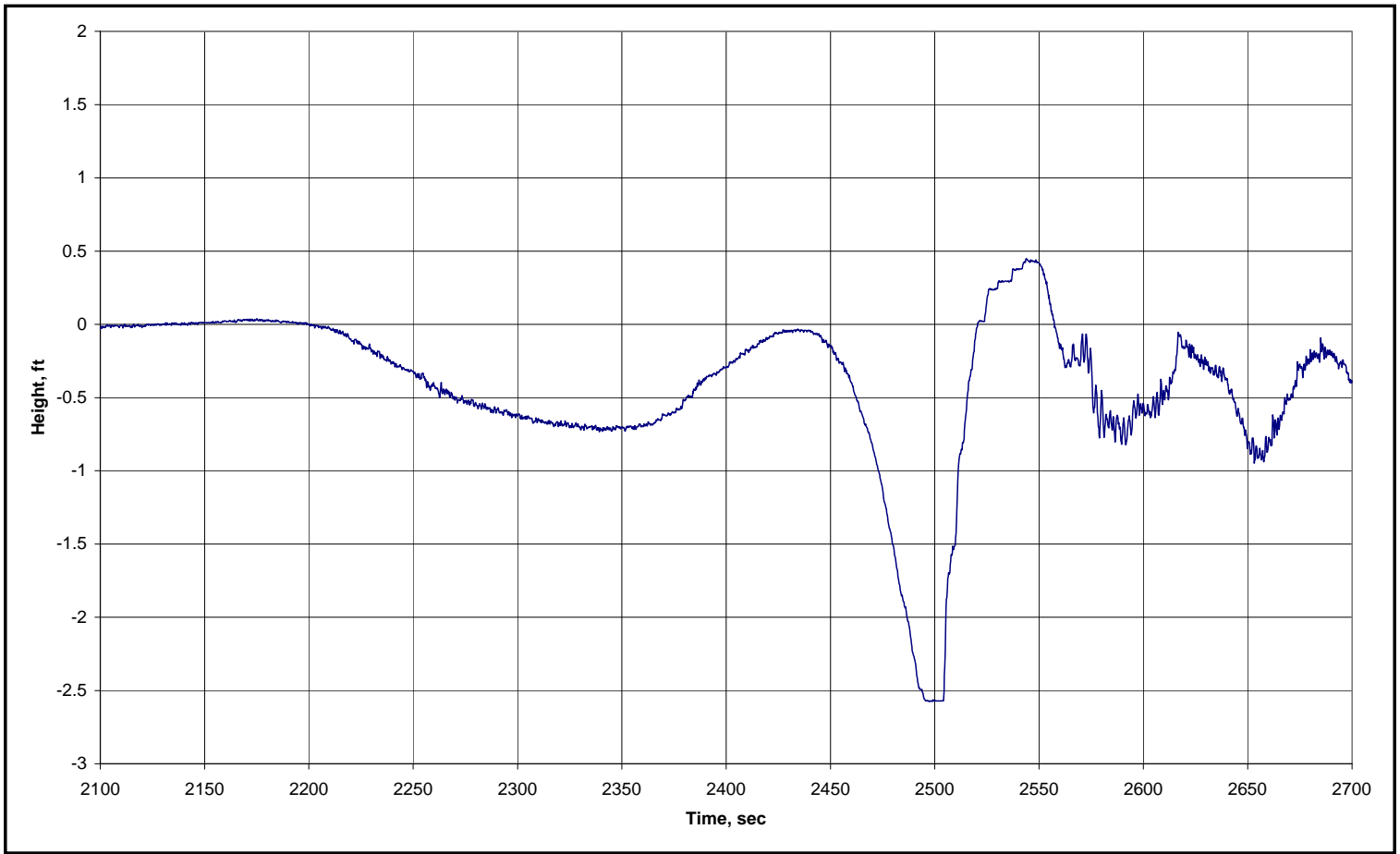

Figure C44. MSC Eleni, outbound, time 0 = 0100 EDT, 18 Sep 2005.

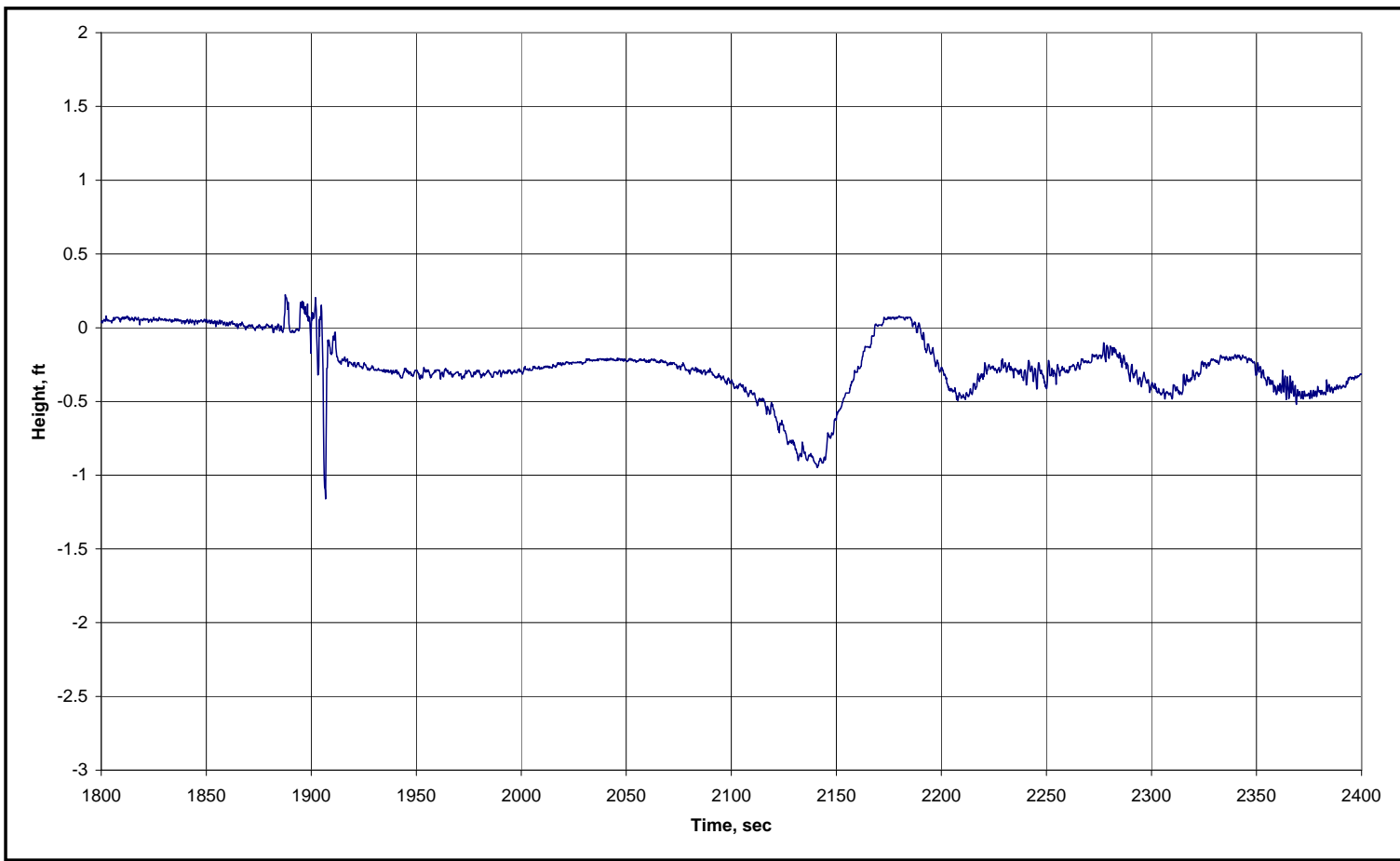

Figure C45. Midnight Sun, outbound, time 0 = 1400 EDT, 18 Sep 2005. 


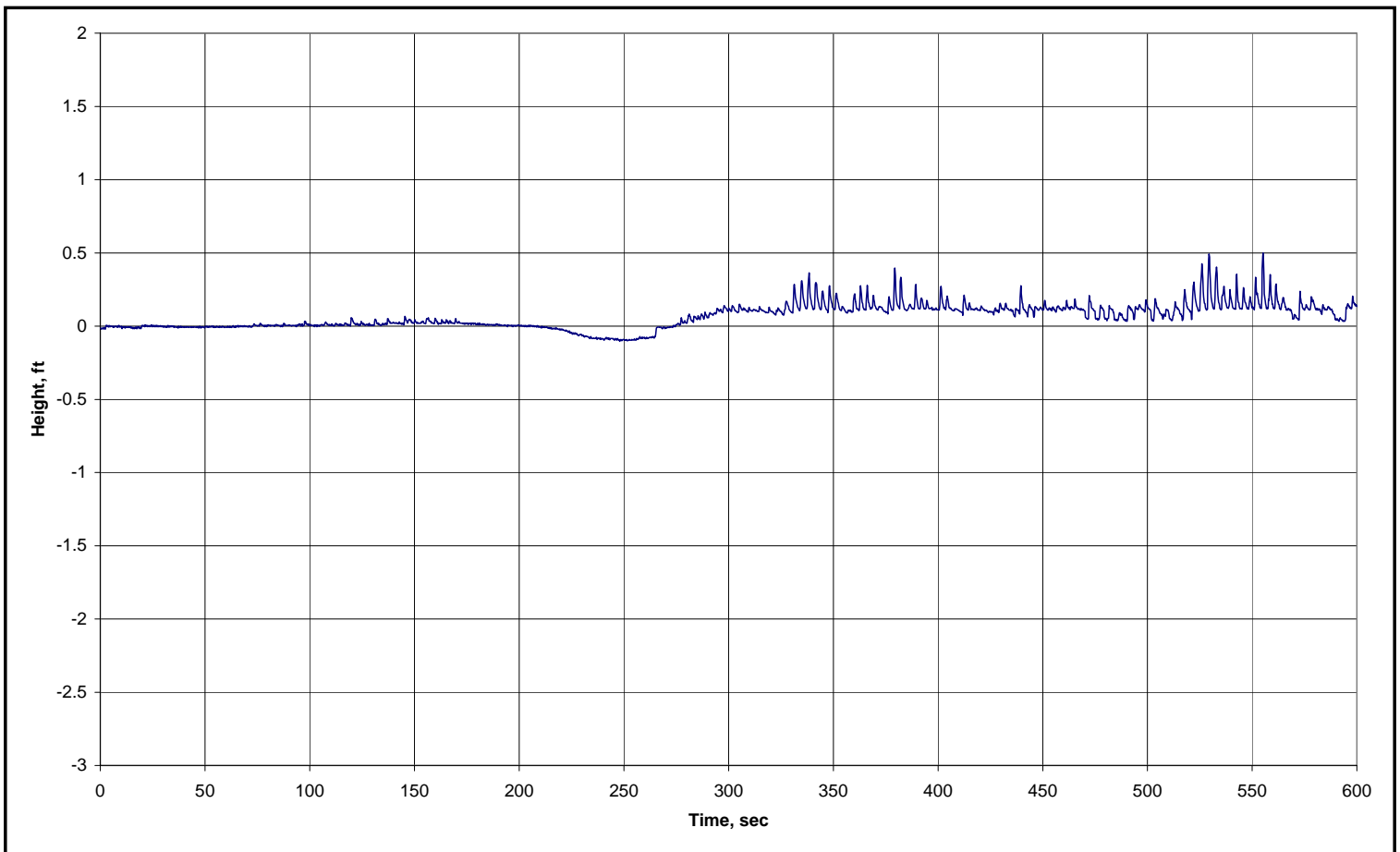

Figure C46. Alyona, outbound, time $0=2100$ EDT, 18 Sep 2005.

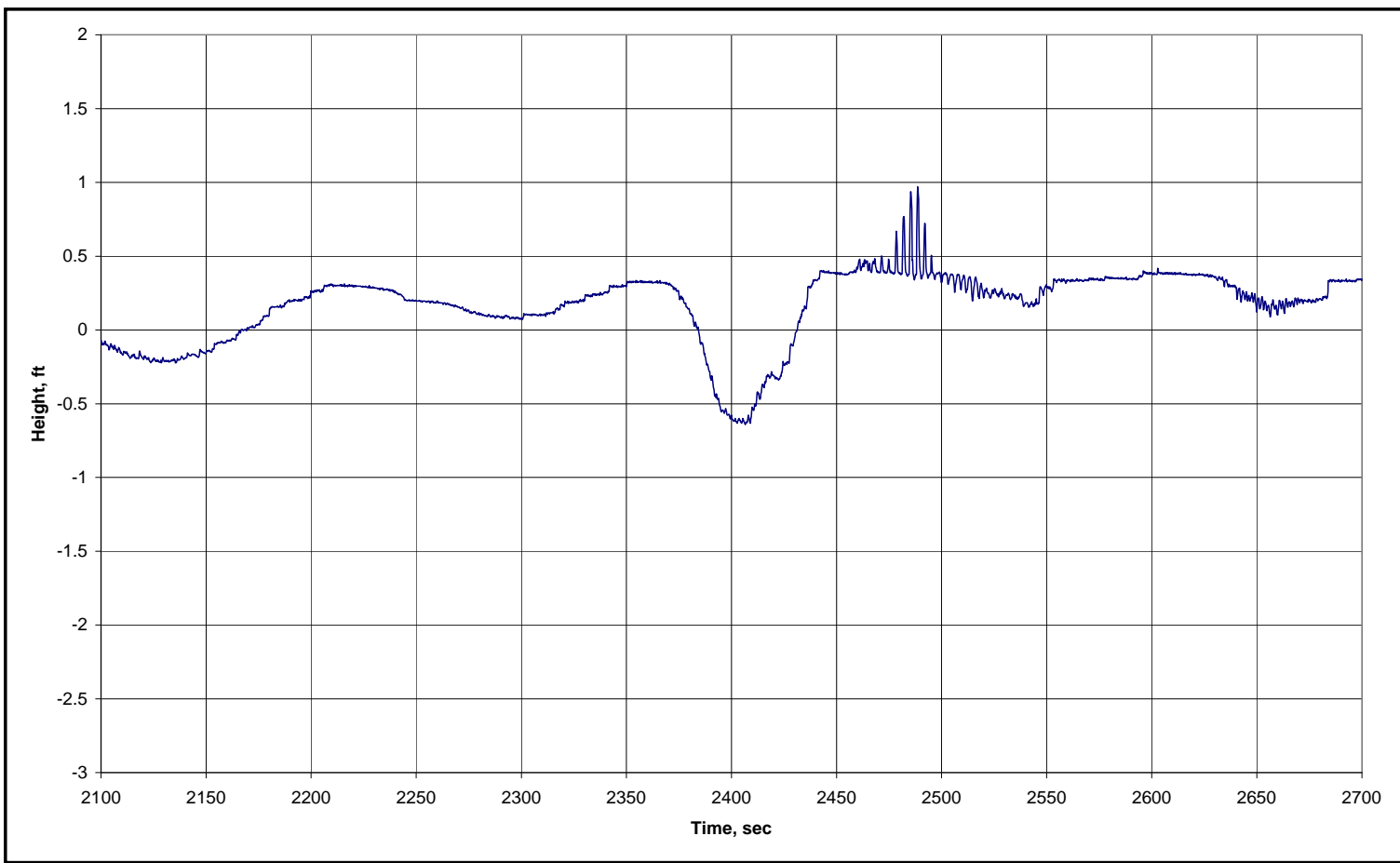

Figure C47. Zim Iberia, outbound, time 0 = 2100 EDT, 18 Sep 2005. 


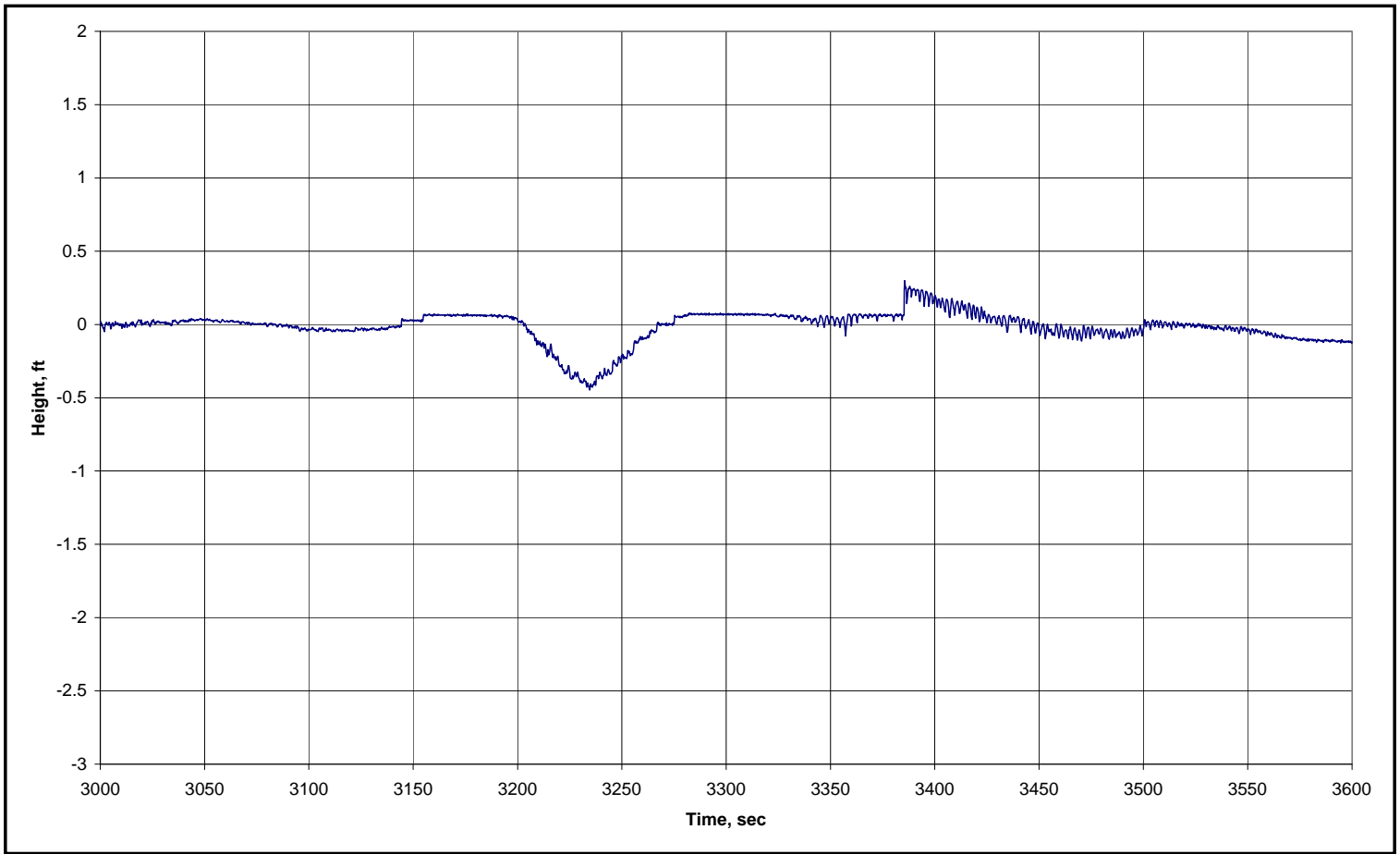

Figure C48. Darya Rani, outbound, time 0 = 2100 EDT, 18 Sep 2005.

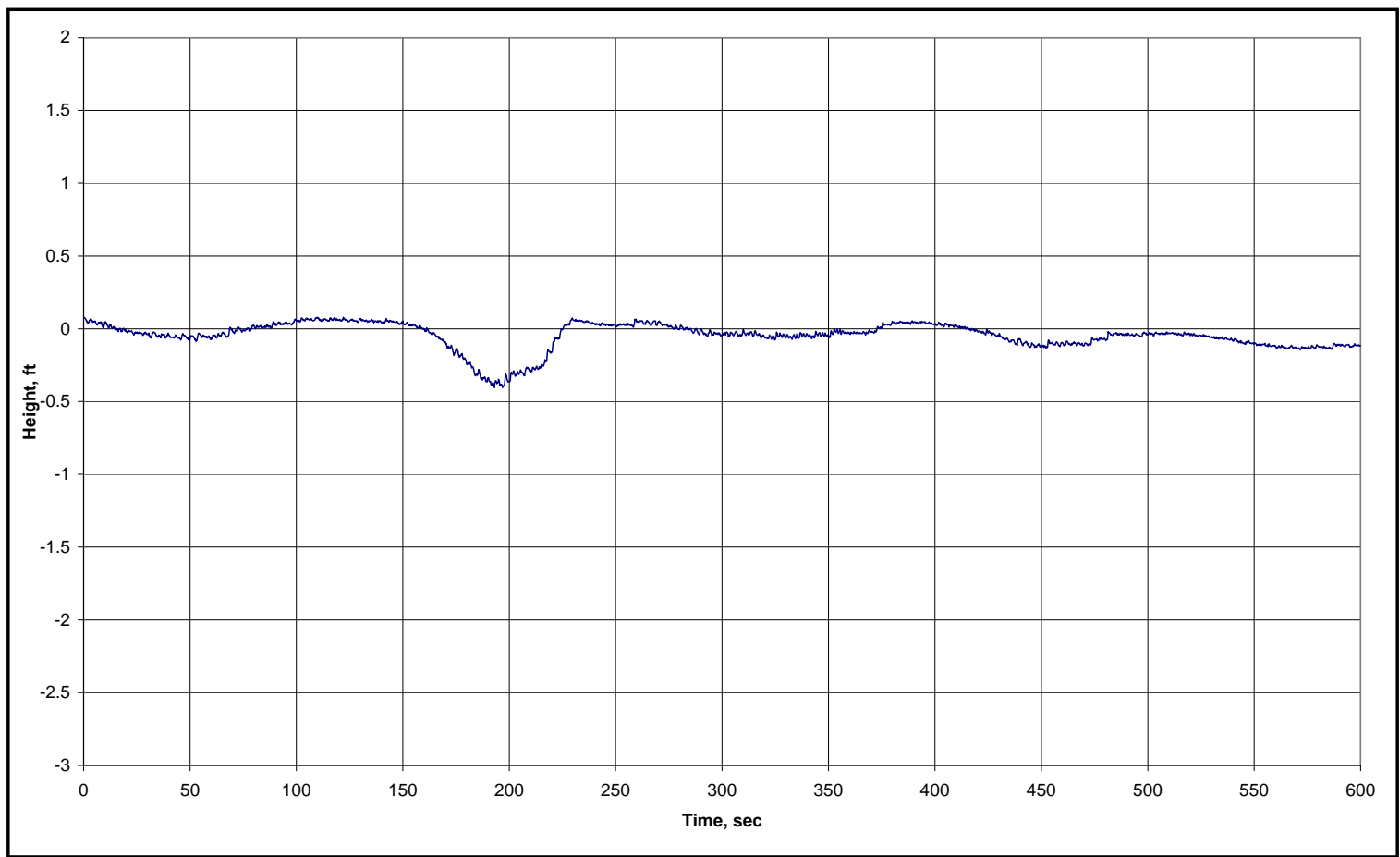

Figure C49. Sumida, outbound, time 0 = 2300 EDT, 18 Sep 2005. 


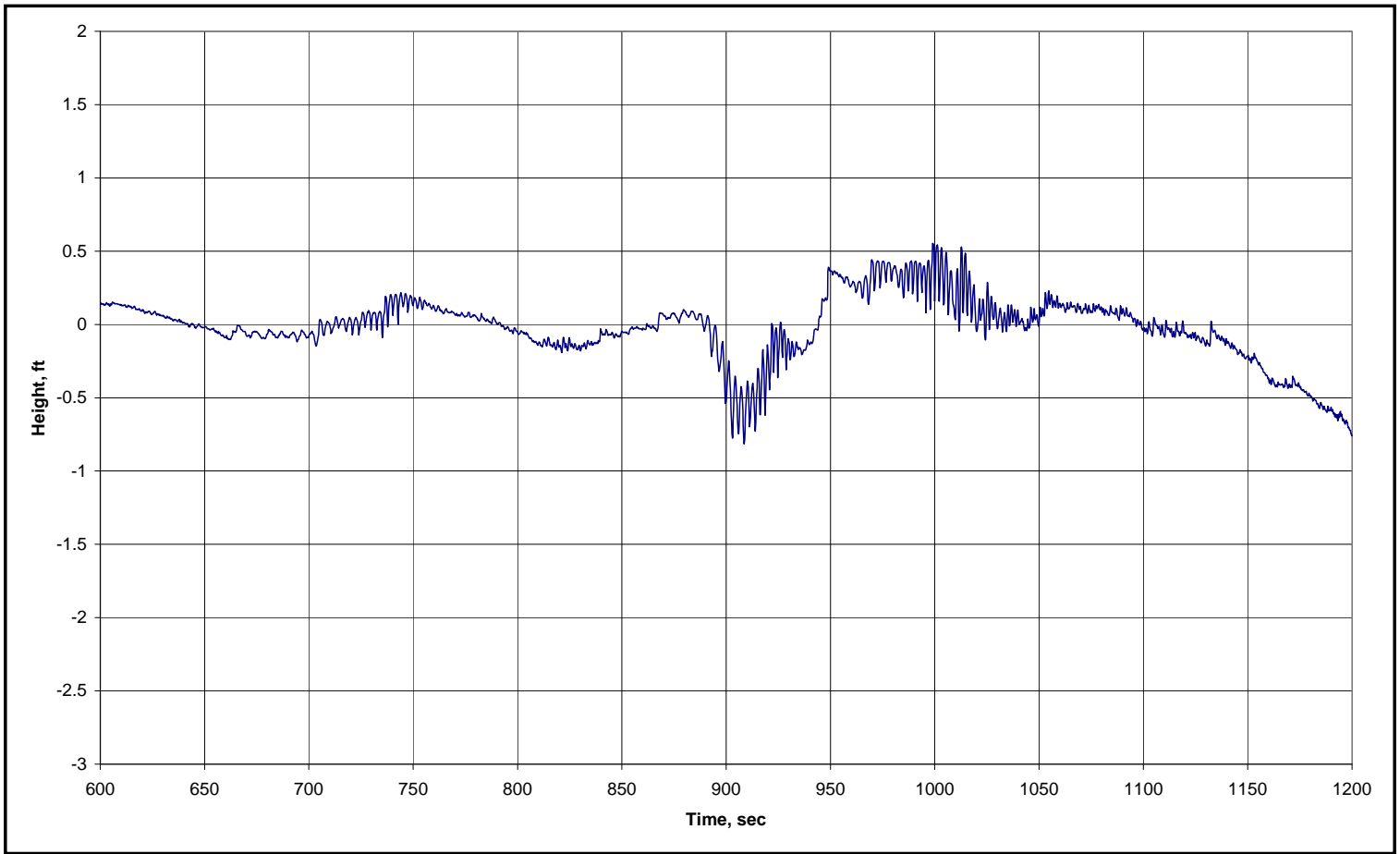

Figure C50. Al Mariyah, outbound, time 0 = 2300 EDT, 18 Sep 2005.

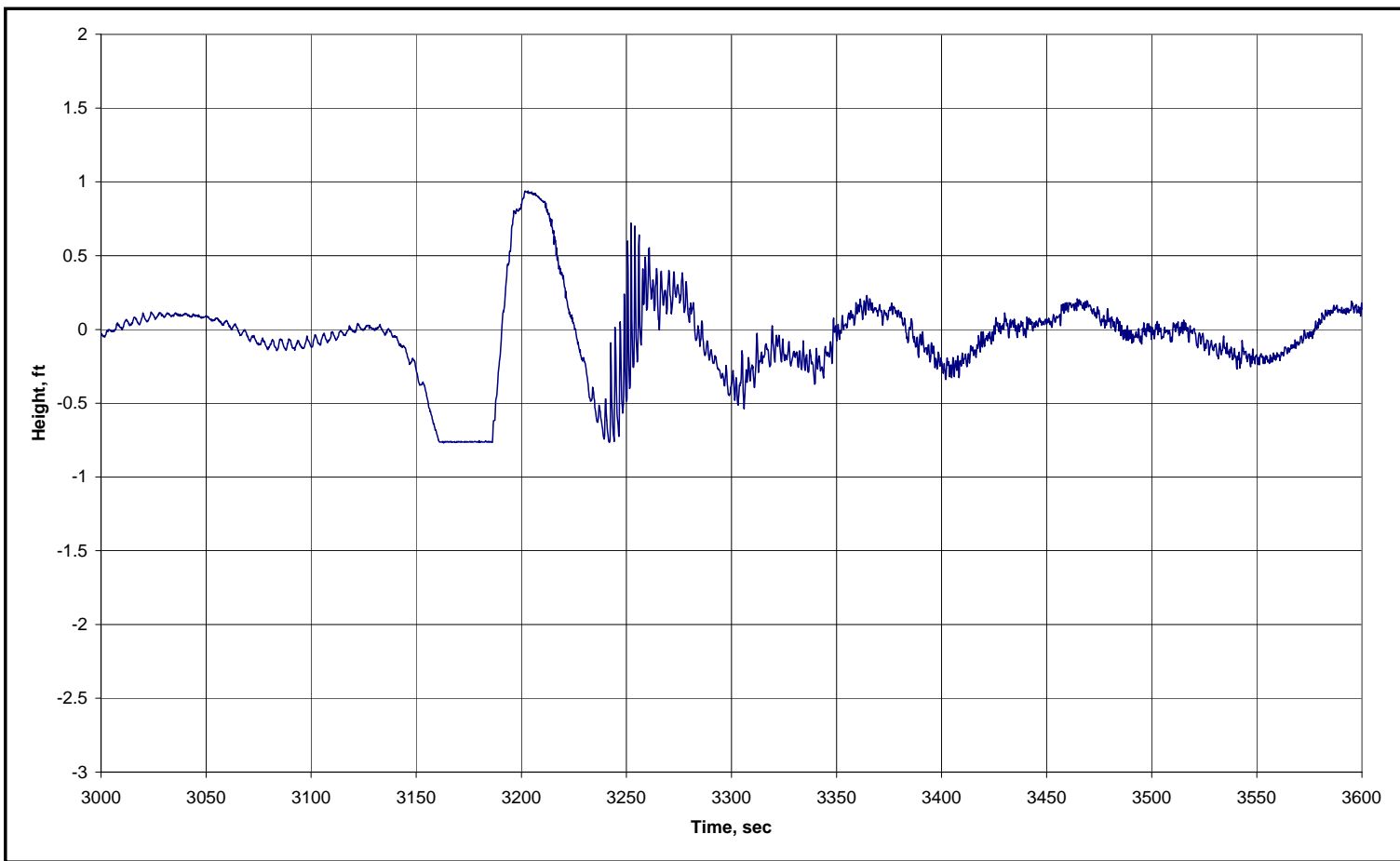

Figure C51. MSC Elena, outbound, time 0 = 0300 EDT, 19 Sep 2005. 


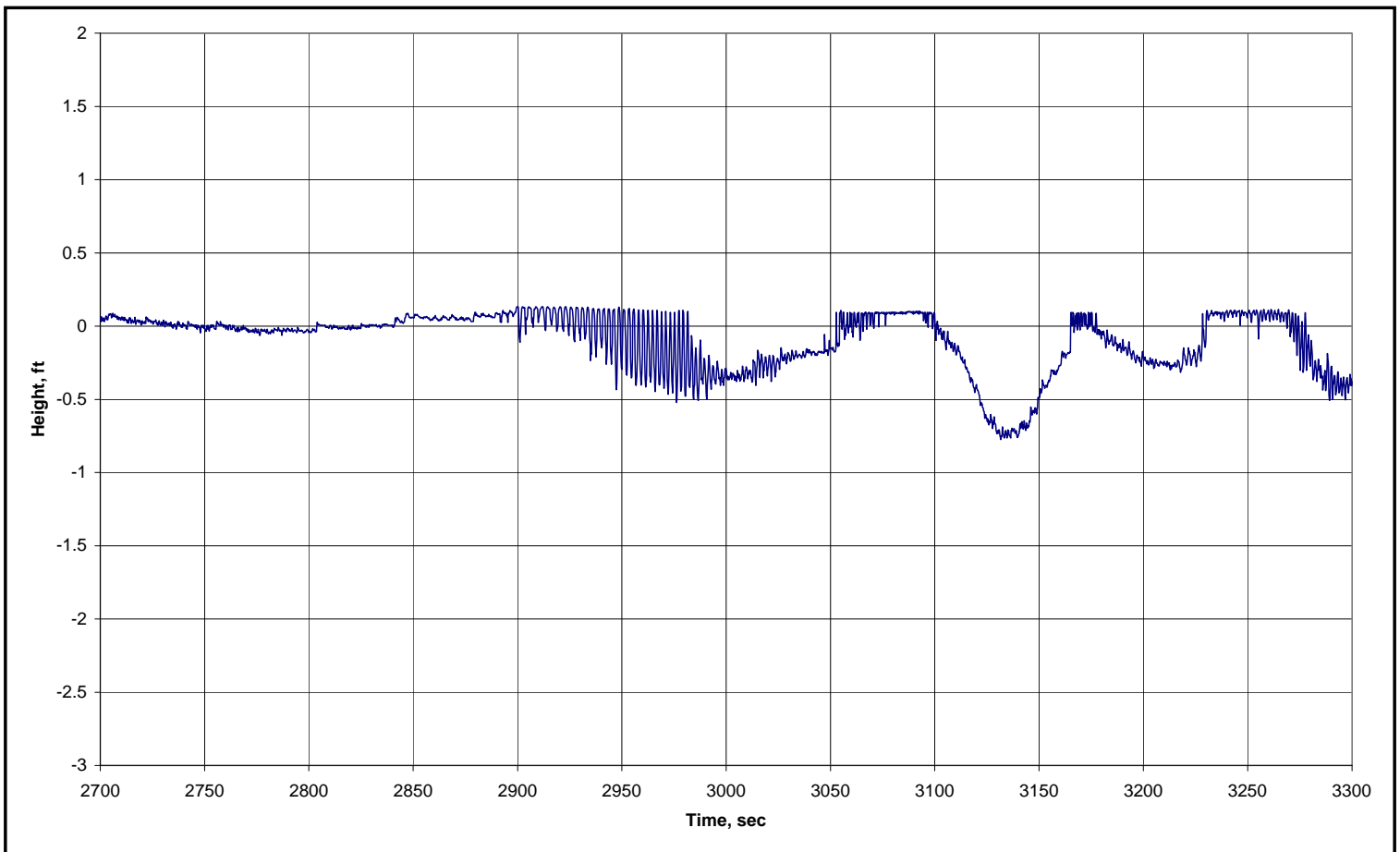

Figure C52. Condor, outbound, time $0=1400$ EDT, 19 Sep 2005.

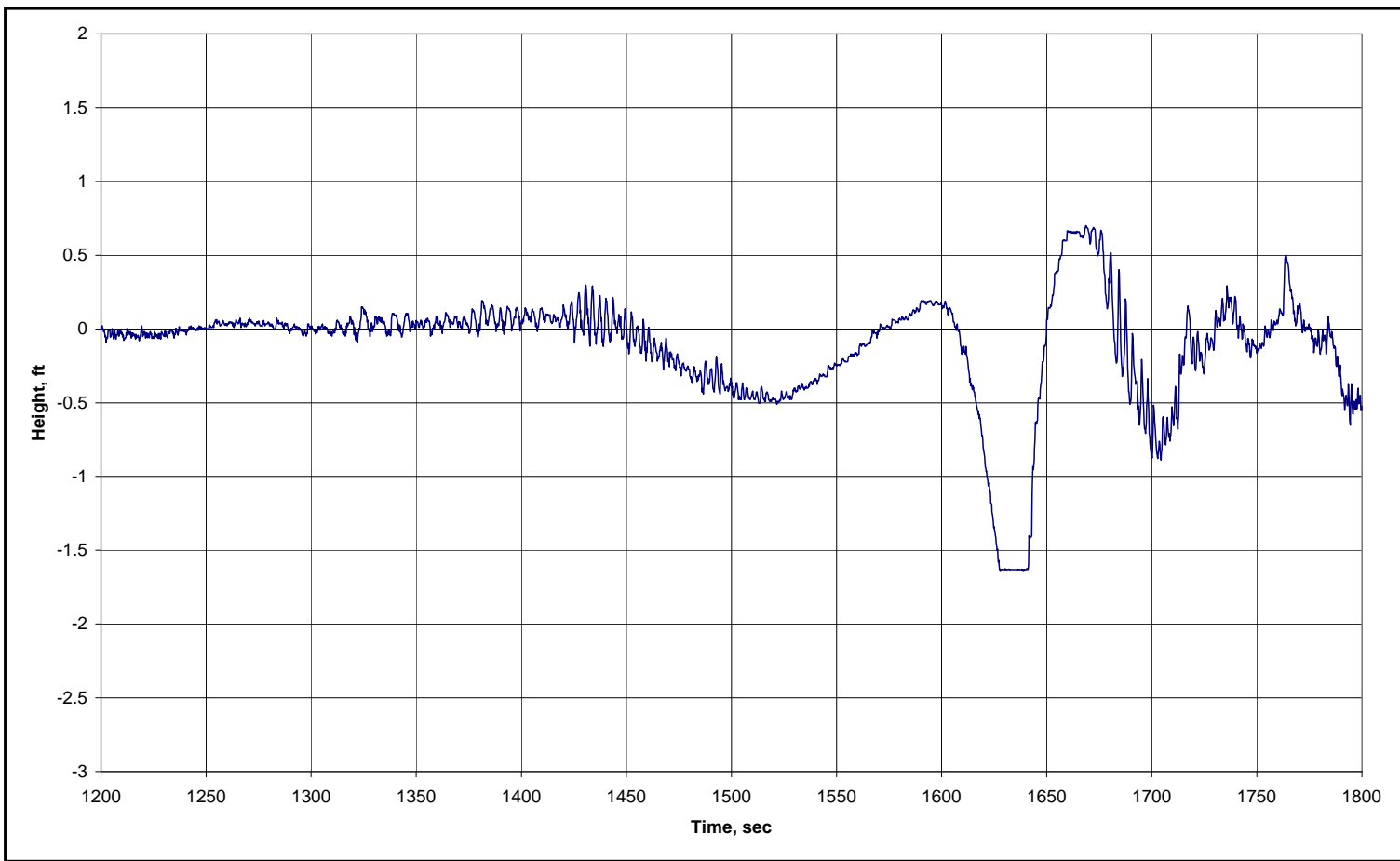

Figure C53. Emmanuel Tomassos, outbound, time 0 = 1500 EDT, 19 Sep 2005. 


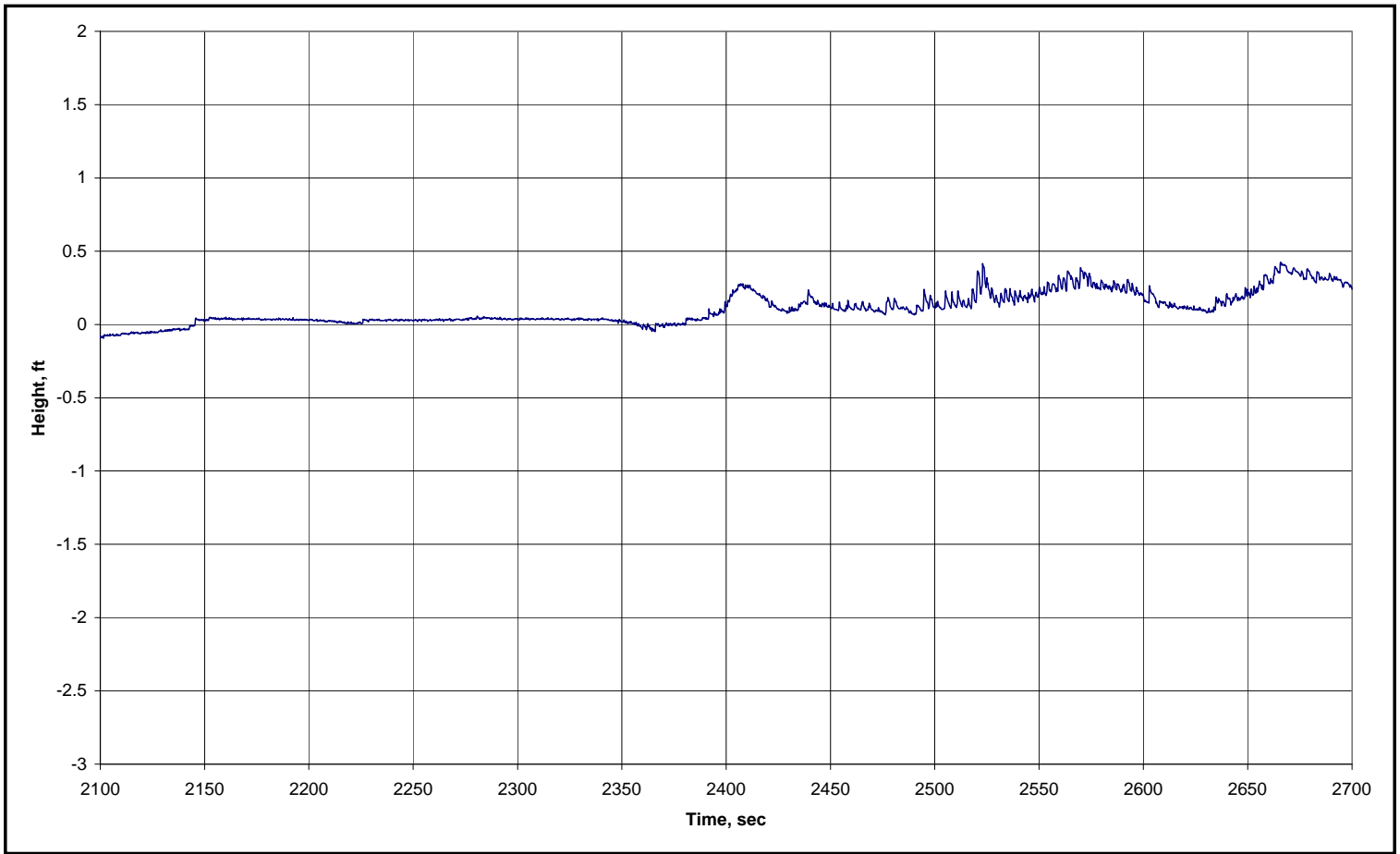

Figure C54. Nelson, outbound, time 0 = 1900 EDT, 19 Sep 2005.

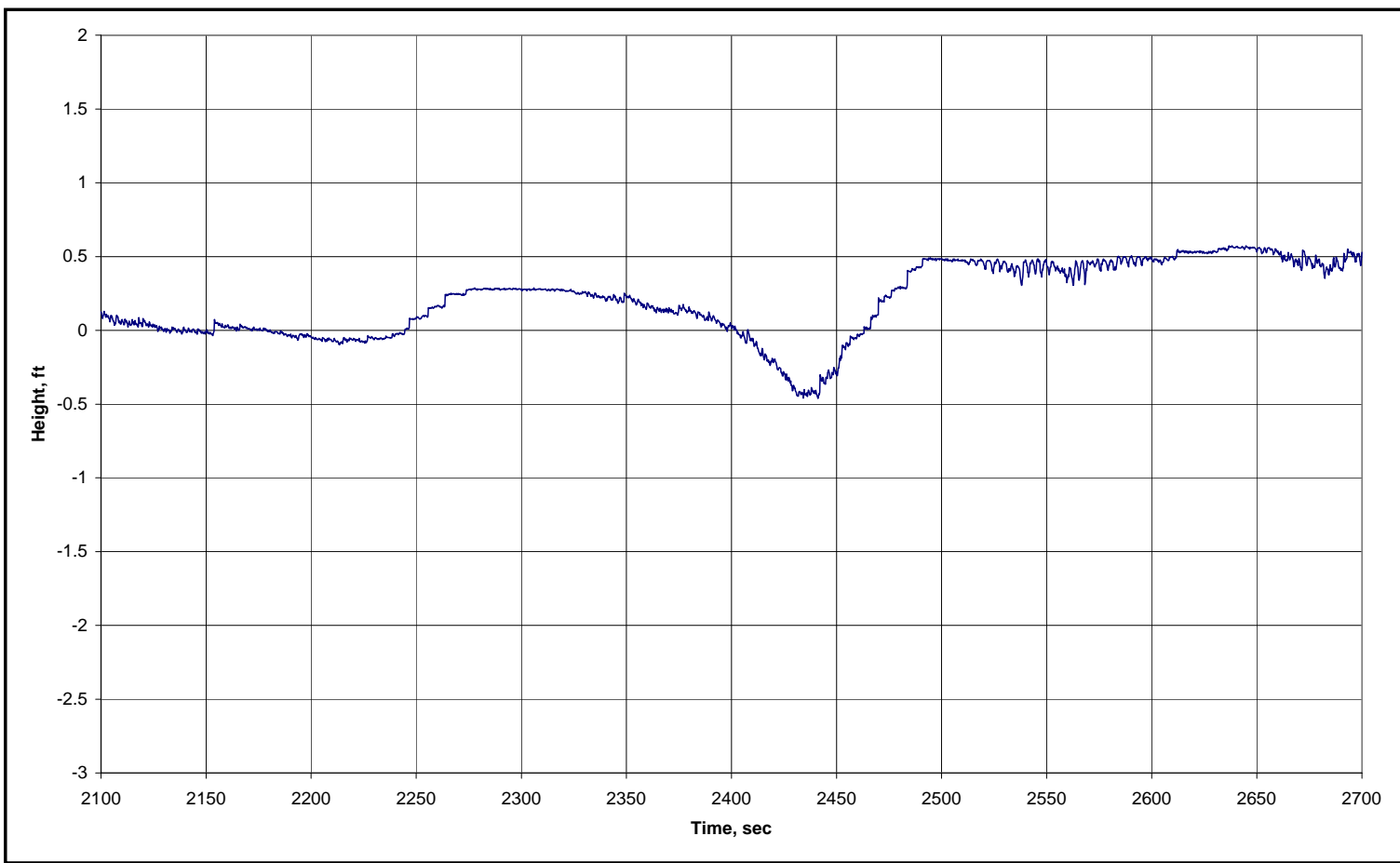

Figure C55. Victoria Bridge, outbound, time $0=2000$ EDT, 19 Sep 2005. 


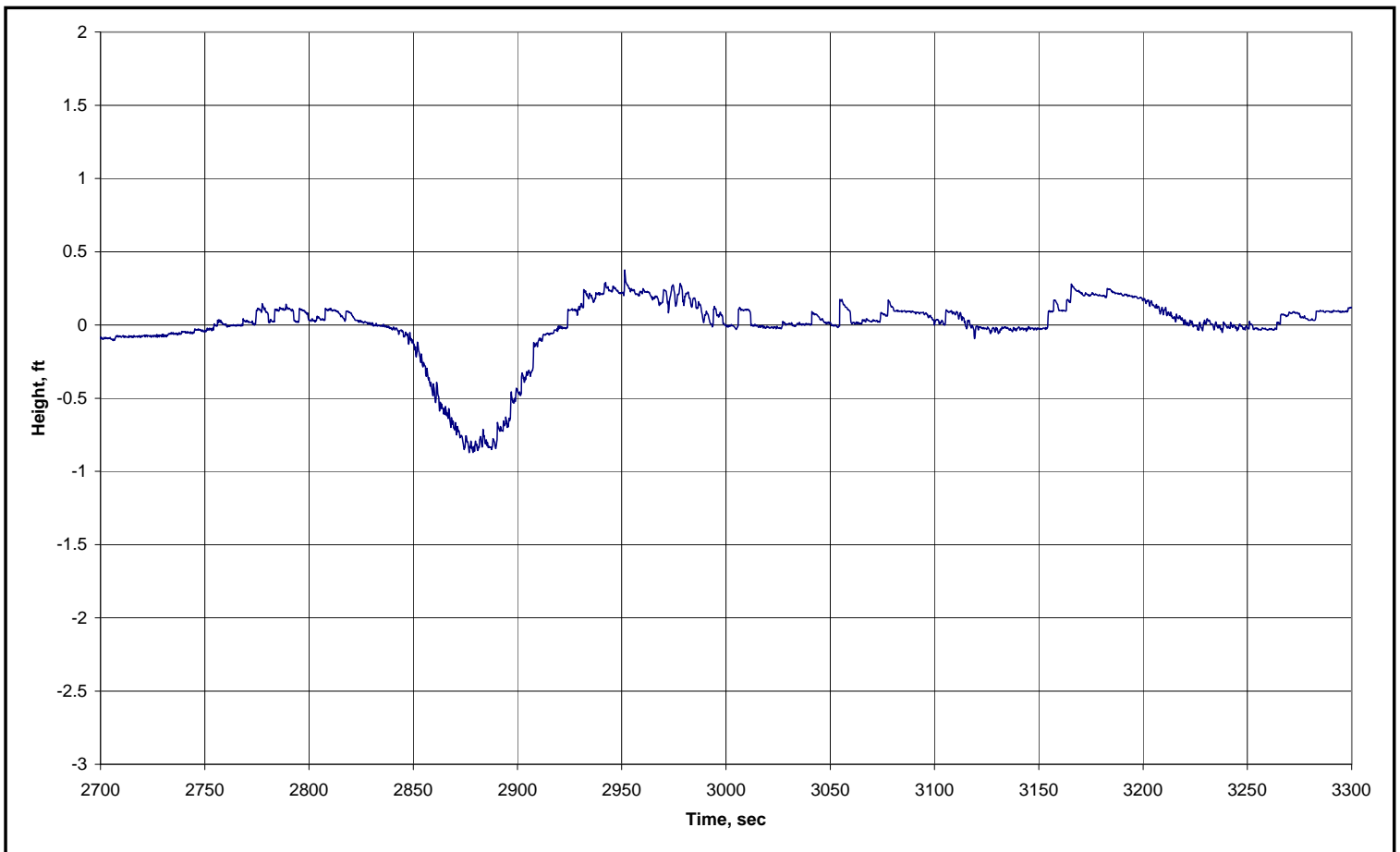

Figure C56. Hanjin Wilmington, outbound, time 0 =2100, 19 Sep 2005.

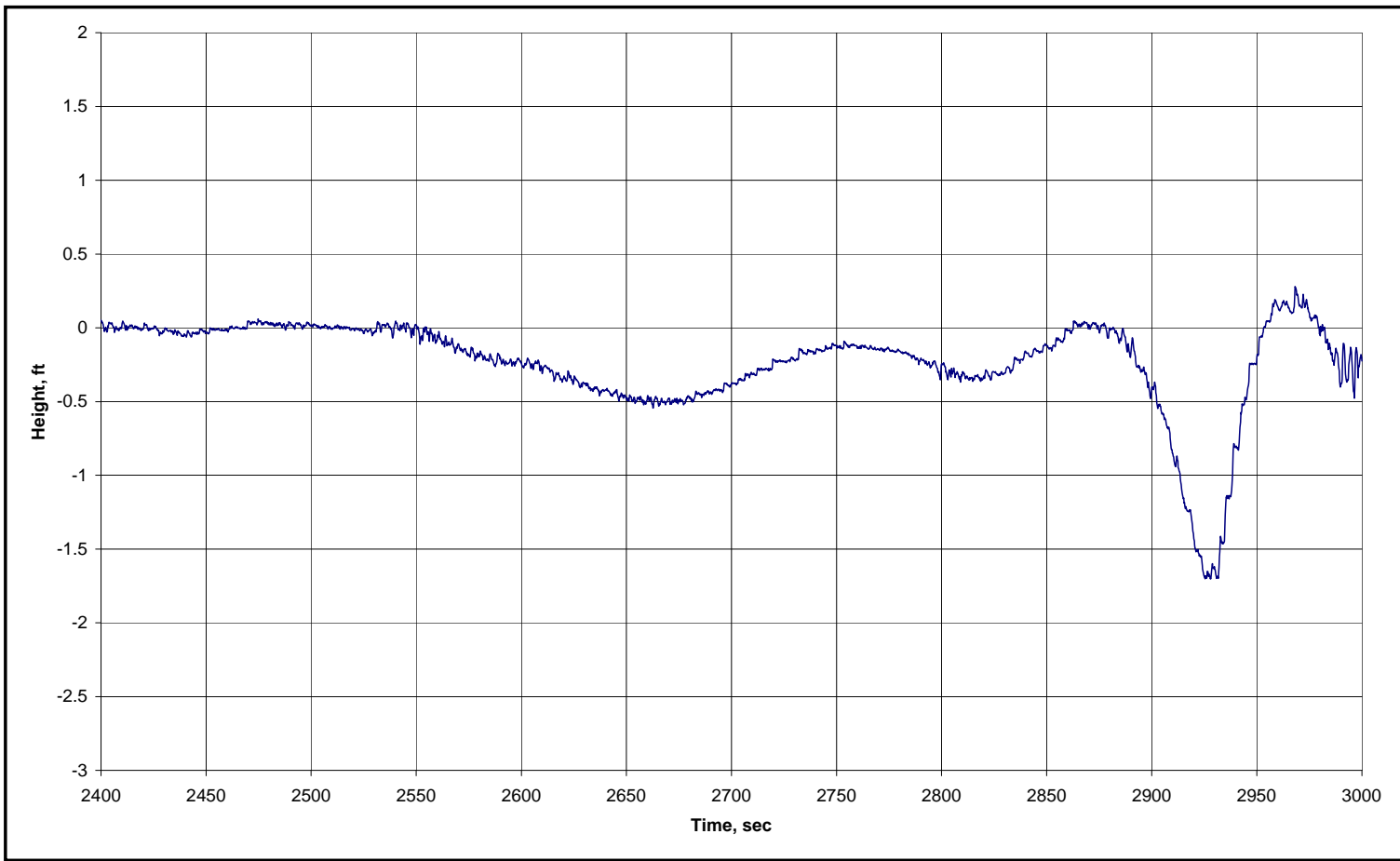

Figure C57. Essen Express, outbound, time 0 = 0300 EDT, 20 Sep 2005. 


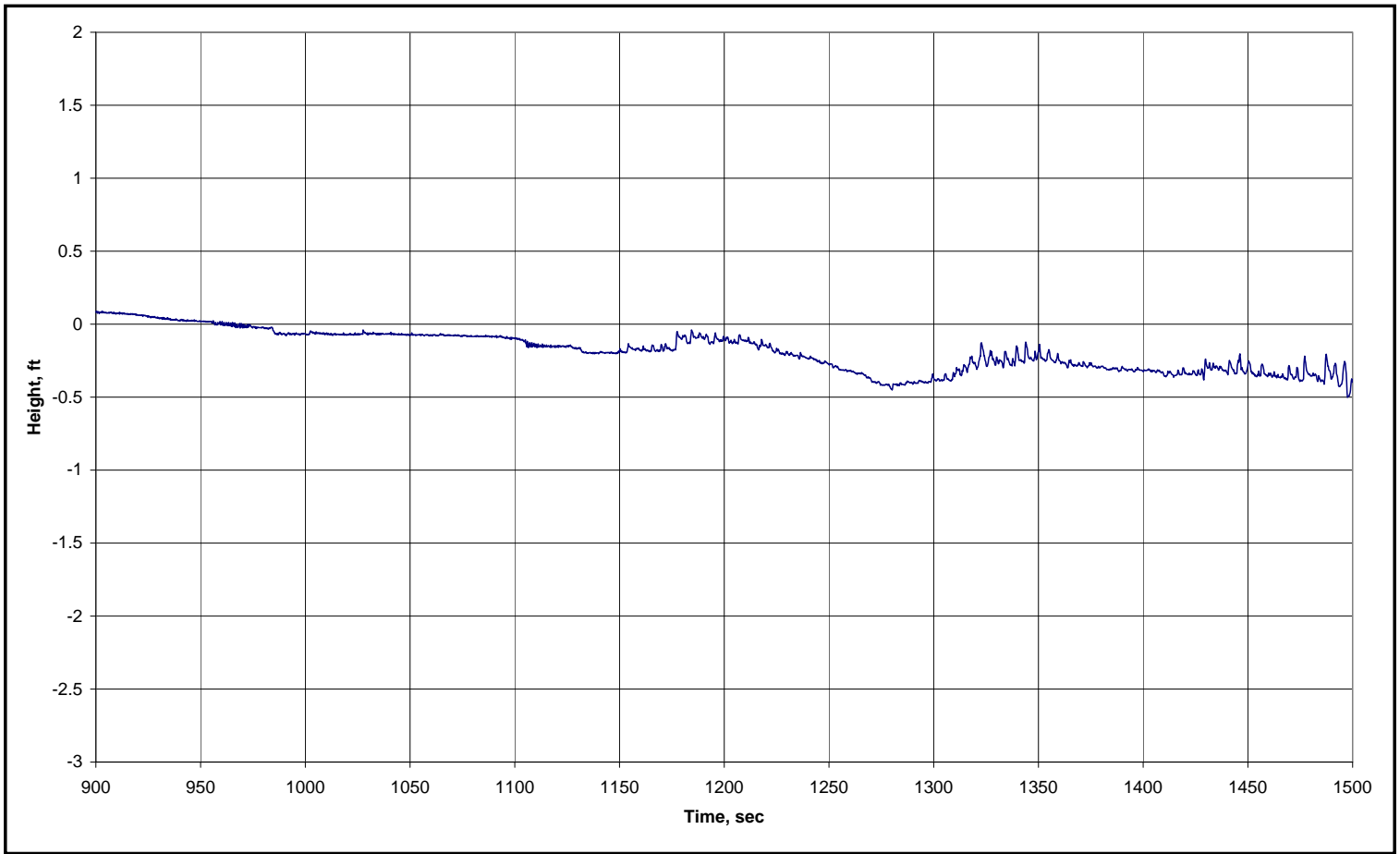

Figure C58. Julia, outbound, time 0 = 0200 EDT, 20 Sep 2005.

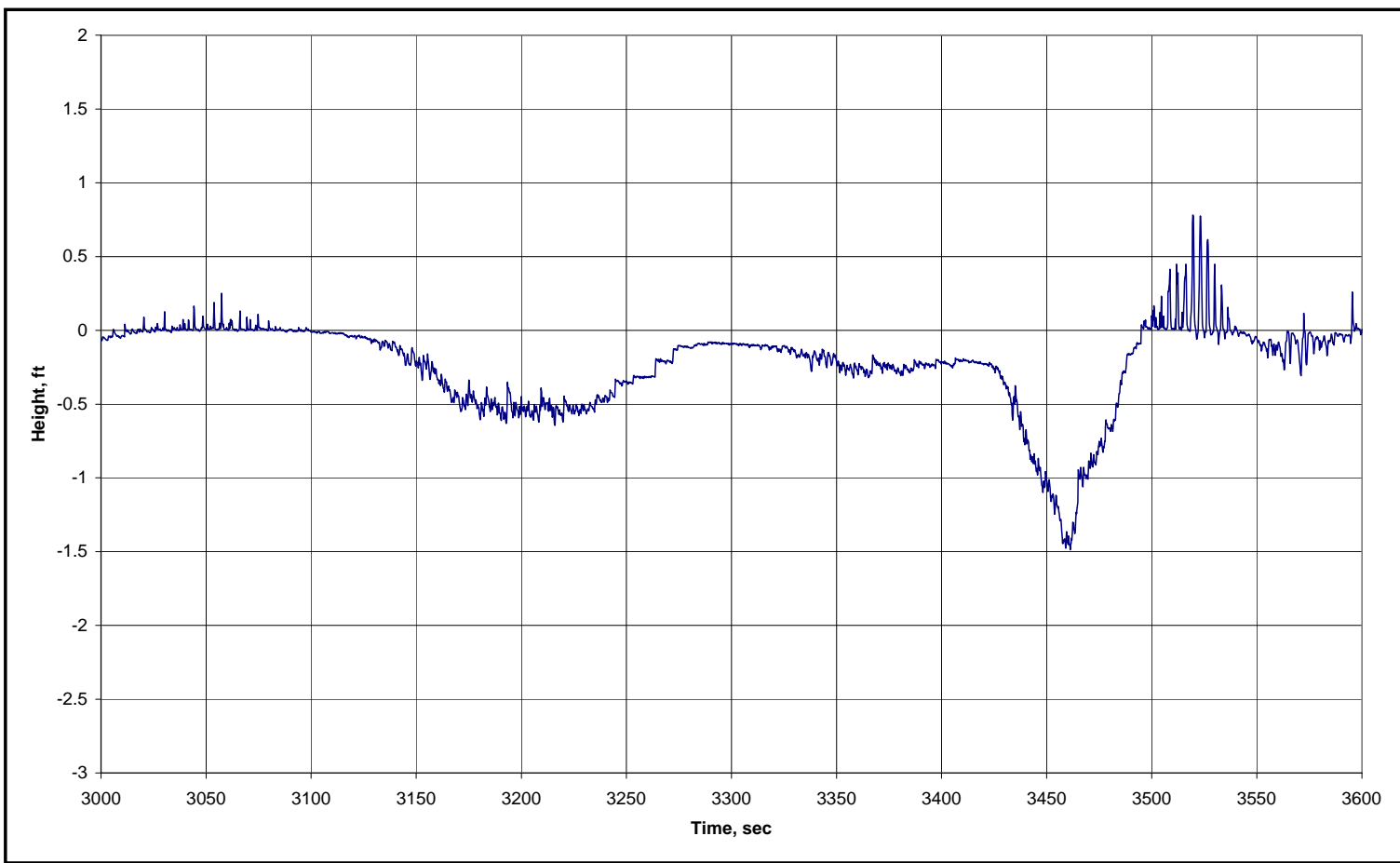

Figure C59. Mol Velocity, outbound, time 0 = 0900 EDT, 20 Sep 2005. 


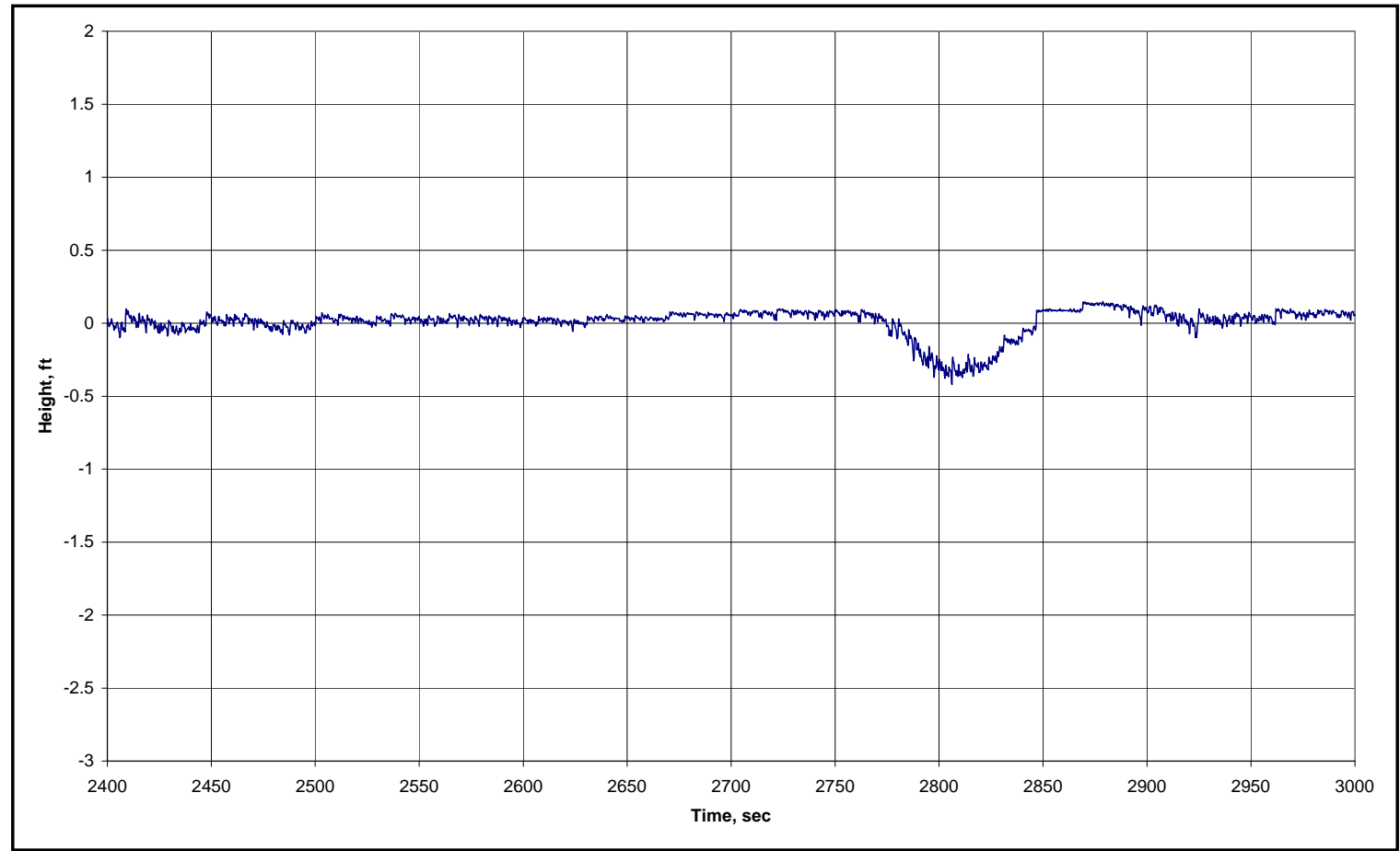

Figure C60. Kavo Alexandros II, outbound, time 0 = 1000 EDT, 20 Sep 2005. 


\section{Appendix D: Ship Wave Height at Tybee Island, Wave Gauge CH3}

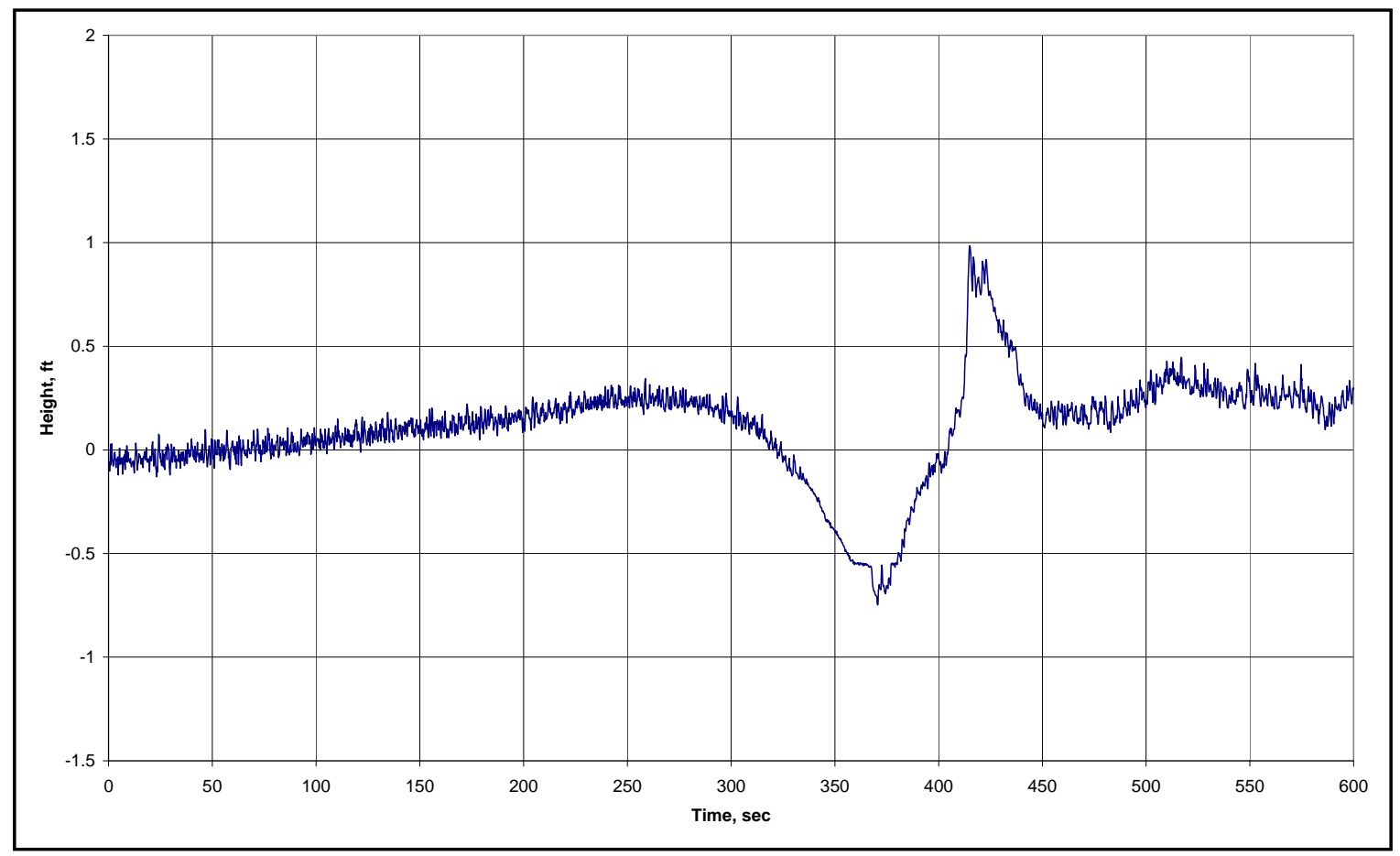

Figure D1. Sun Right, inbound, time 0 = 1500 EDT, 16 Sep 2005. 


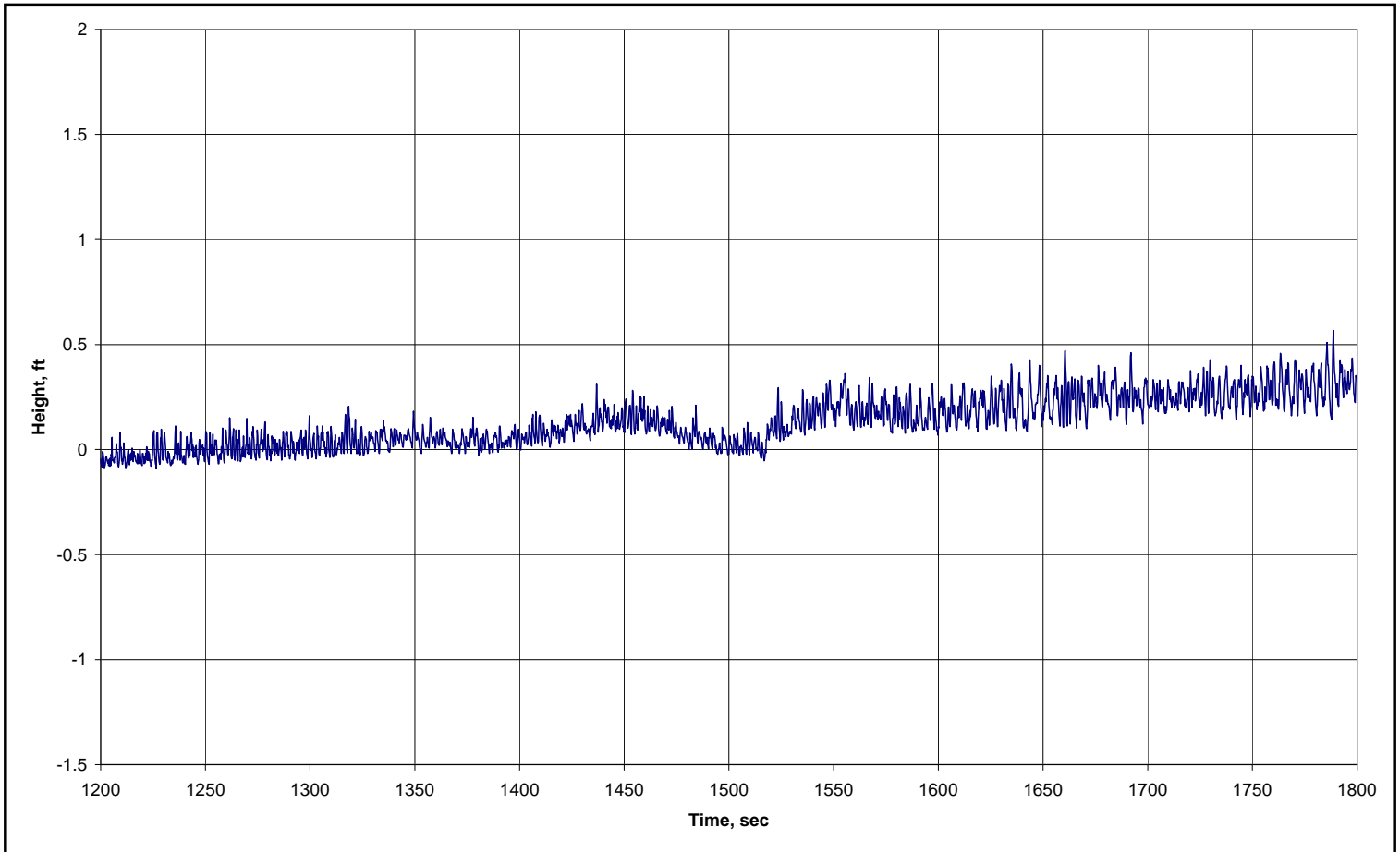

Figure D2. Mol Americas, inbound, time 0 = 1700 EDT, 16 Sep 2005.

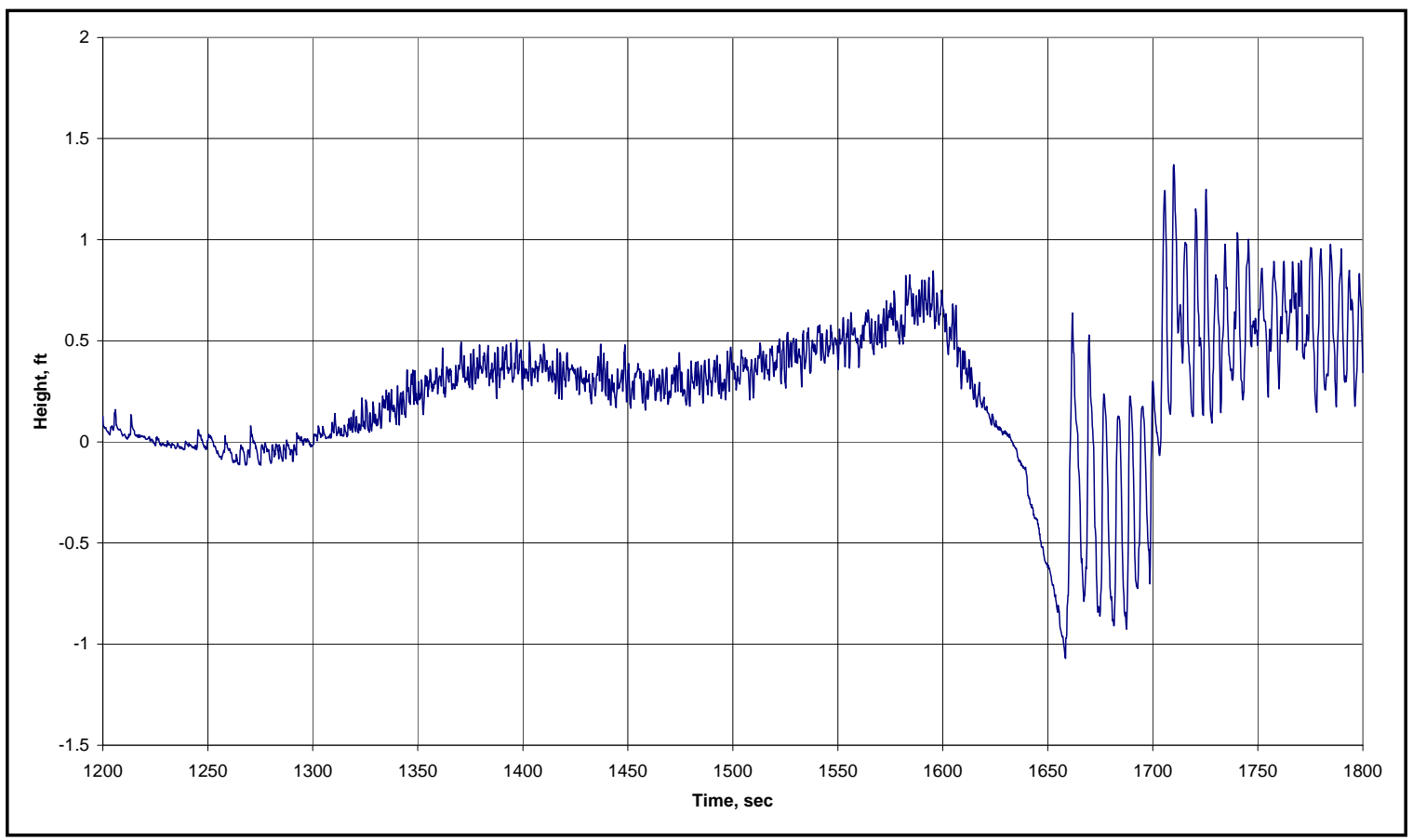

Figure D3. Jens Maersk (in) and Talisman (out), time 0 = 1800 EDT, 16 Sep 2005. 


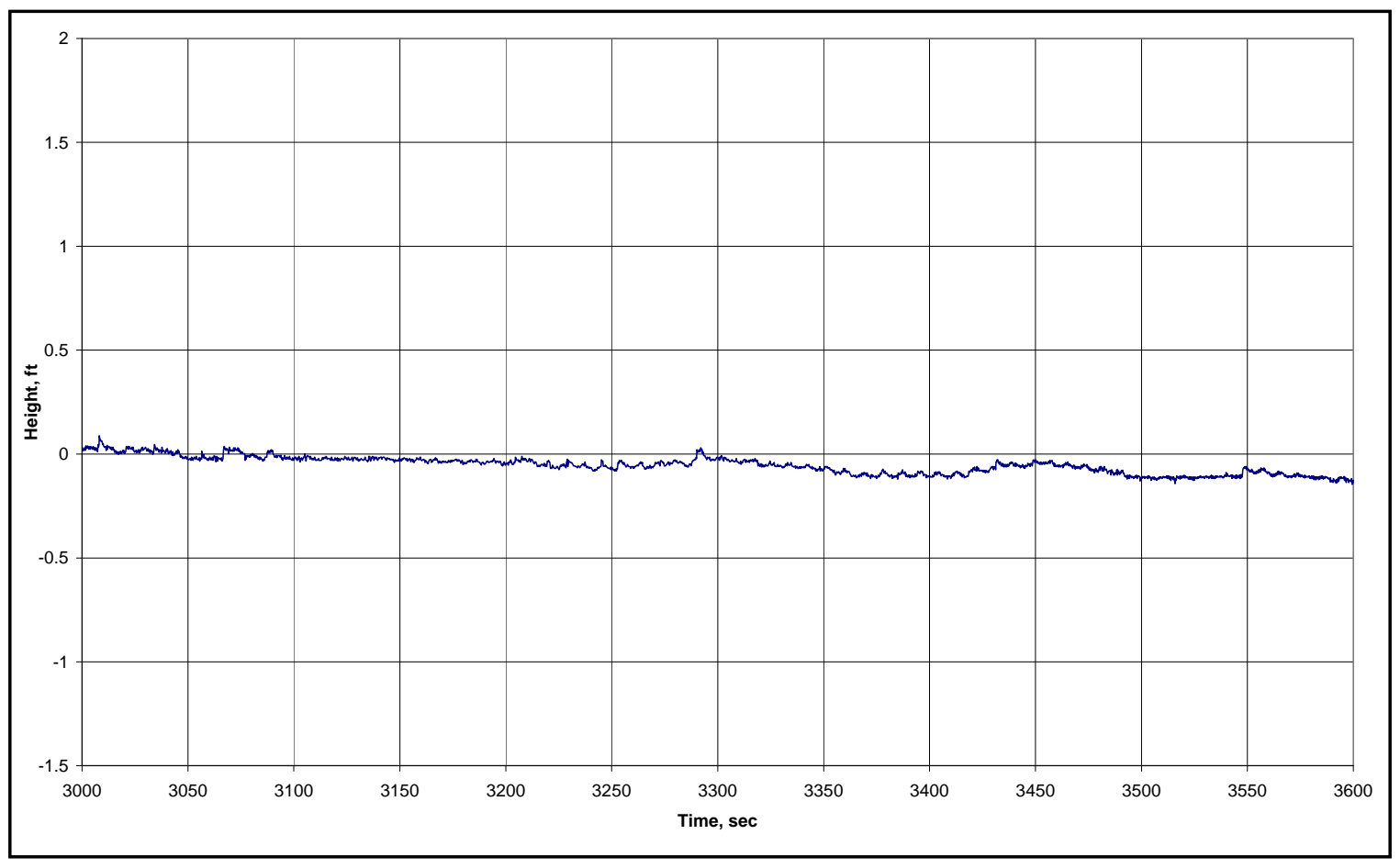

Figure D4. CMA CGM Potomoc, inbound, time 0 = 2000 EDT, 16 Sep 2005.

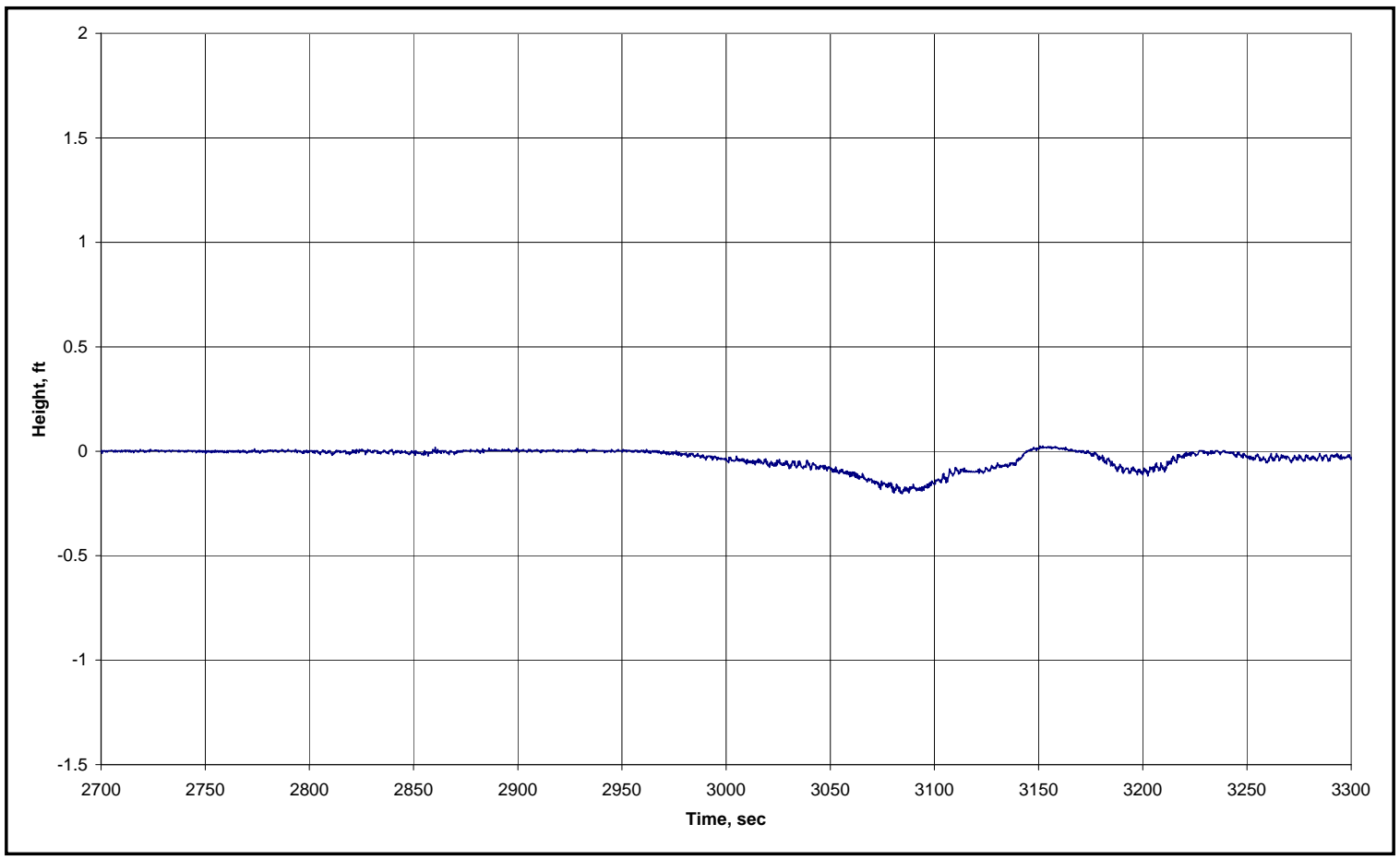

Figure D5. Zim Israel, inbound, time 0 = 0100 EDT, 17 Sep 2005. 


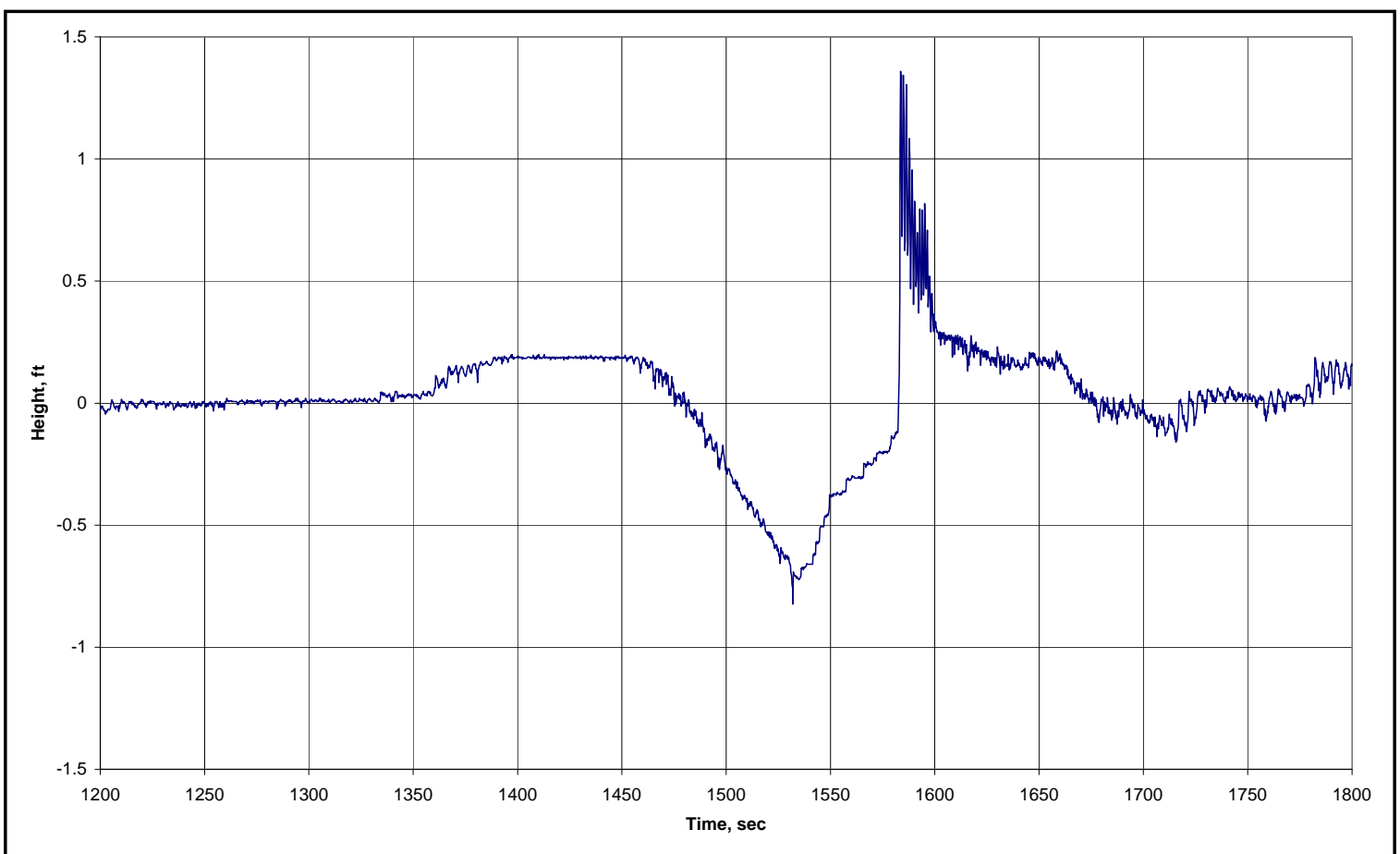

Figure D6. MSC Christina, inbound, time 0 = 0200 EDT, 17 Sep 2005.

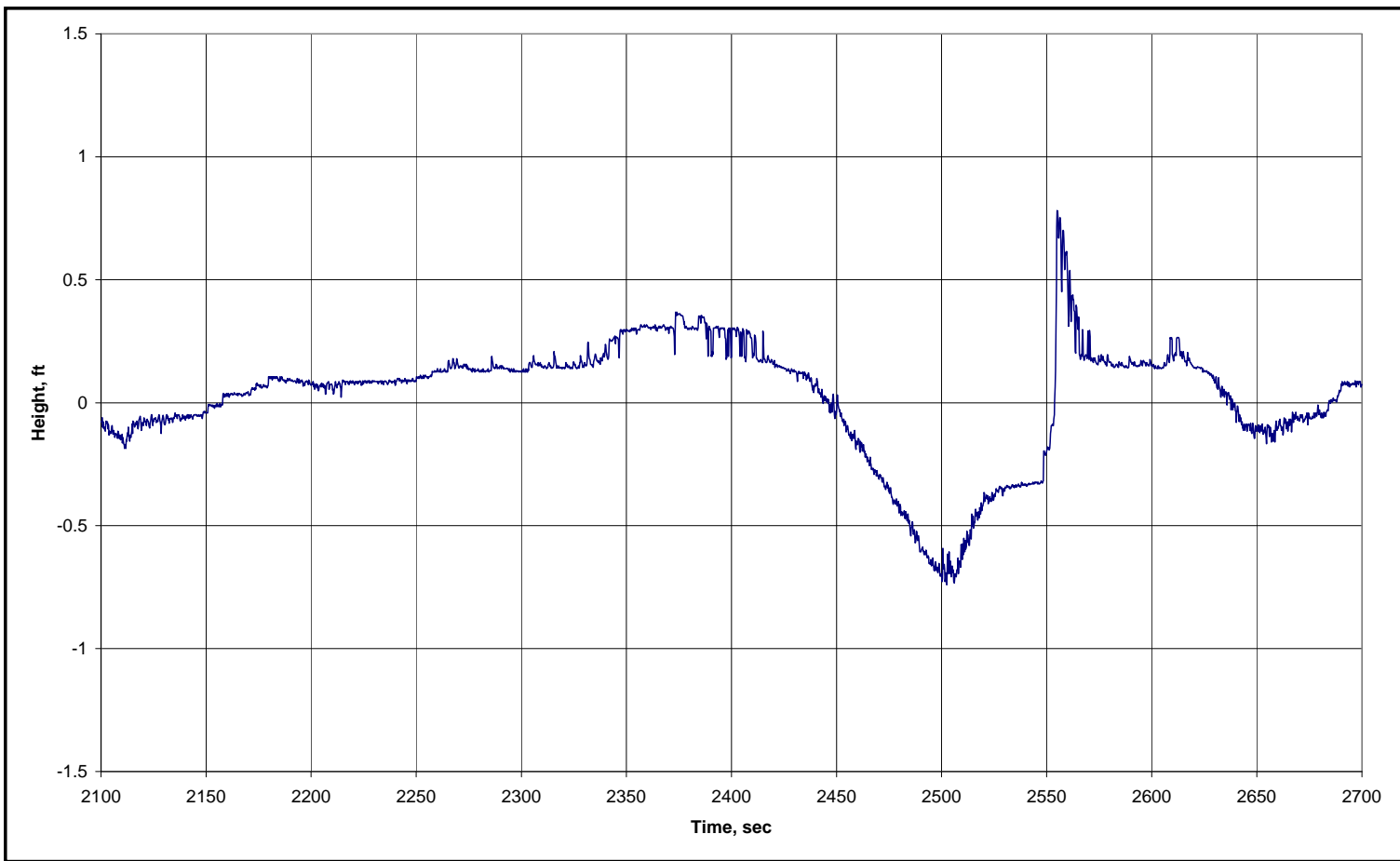

Figure D7. MSC Christina, inbound, time 0 = 0200 EDT, 17 Sep 2005. 
ERDC/CHL TR-07-7

116

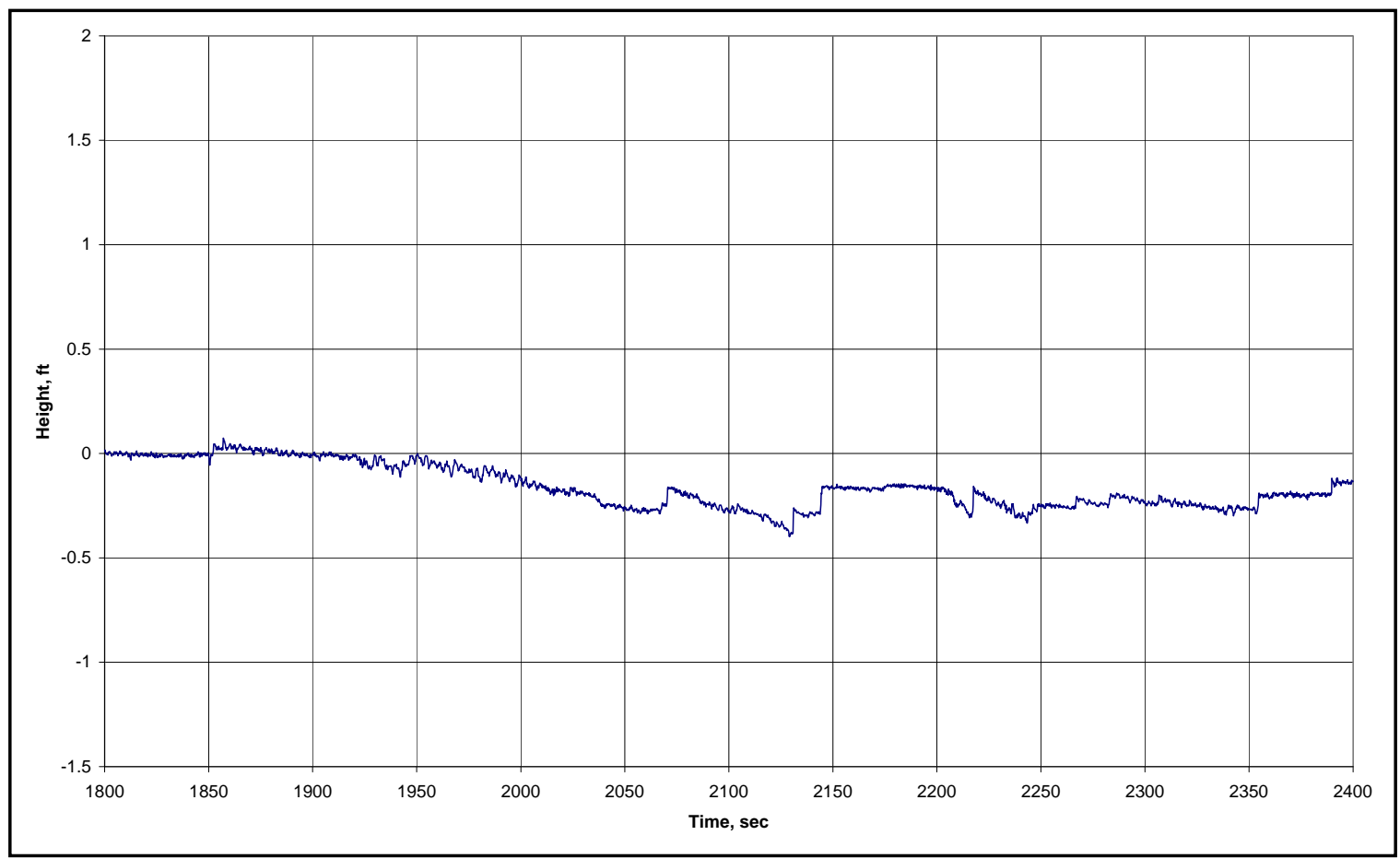

Figure D8. MSC Elemi, inbound, time 0 = 0800 EDT, 17 Sep 2005.

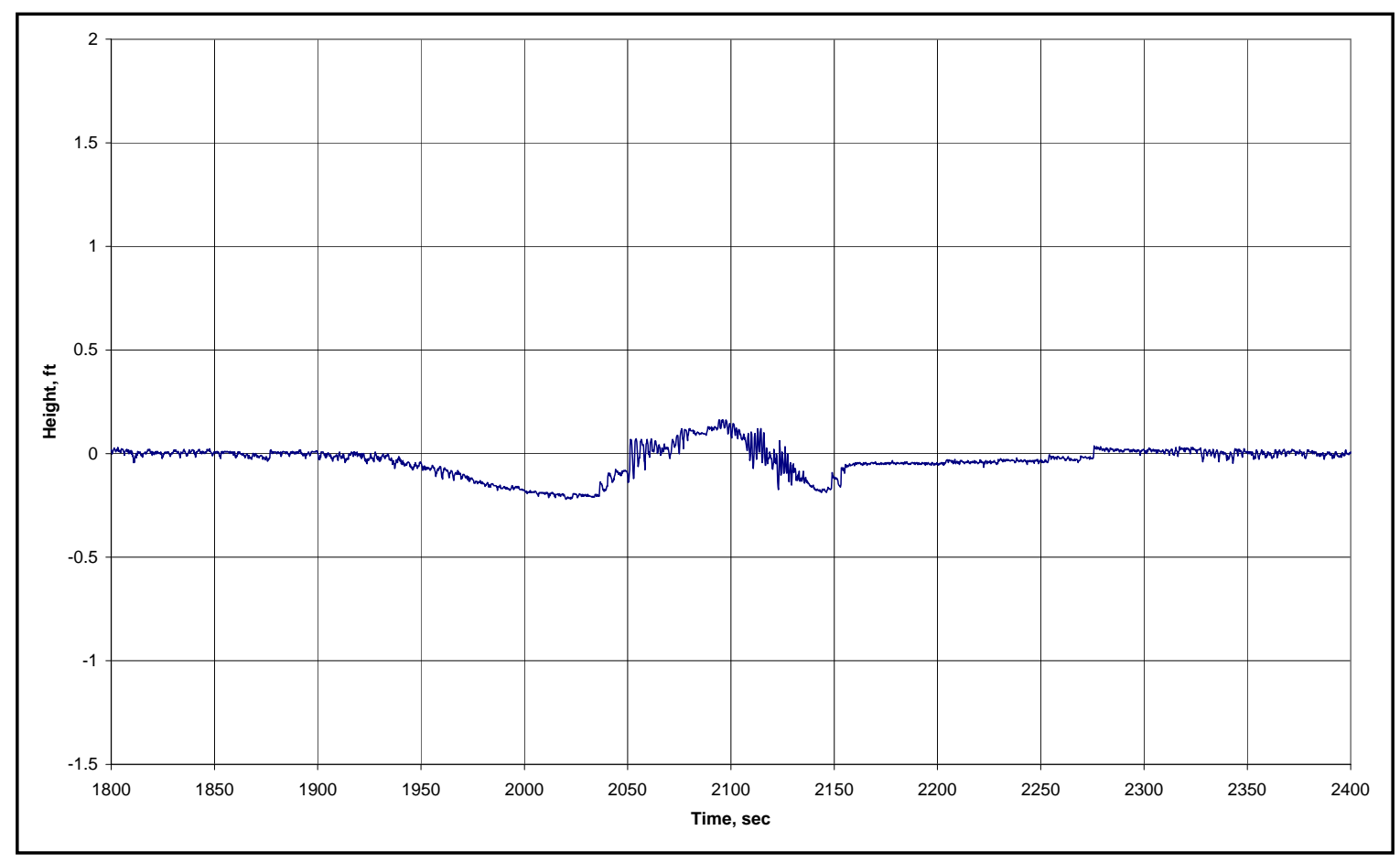

Figure D9. Midnight Sun, inbound, time 0 = 1400 EDT, 17 Sep 2005. 


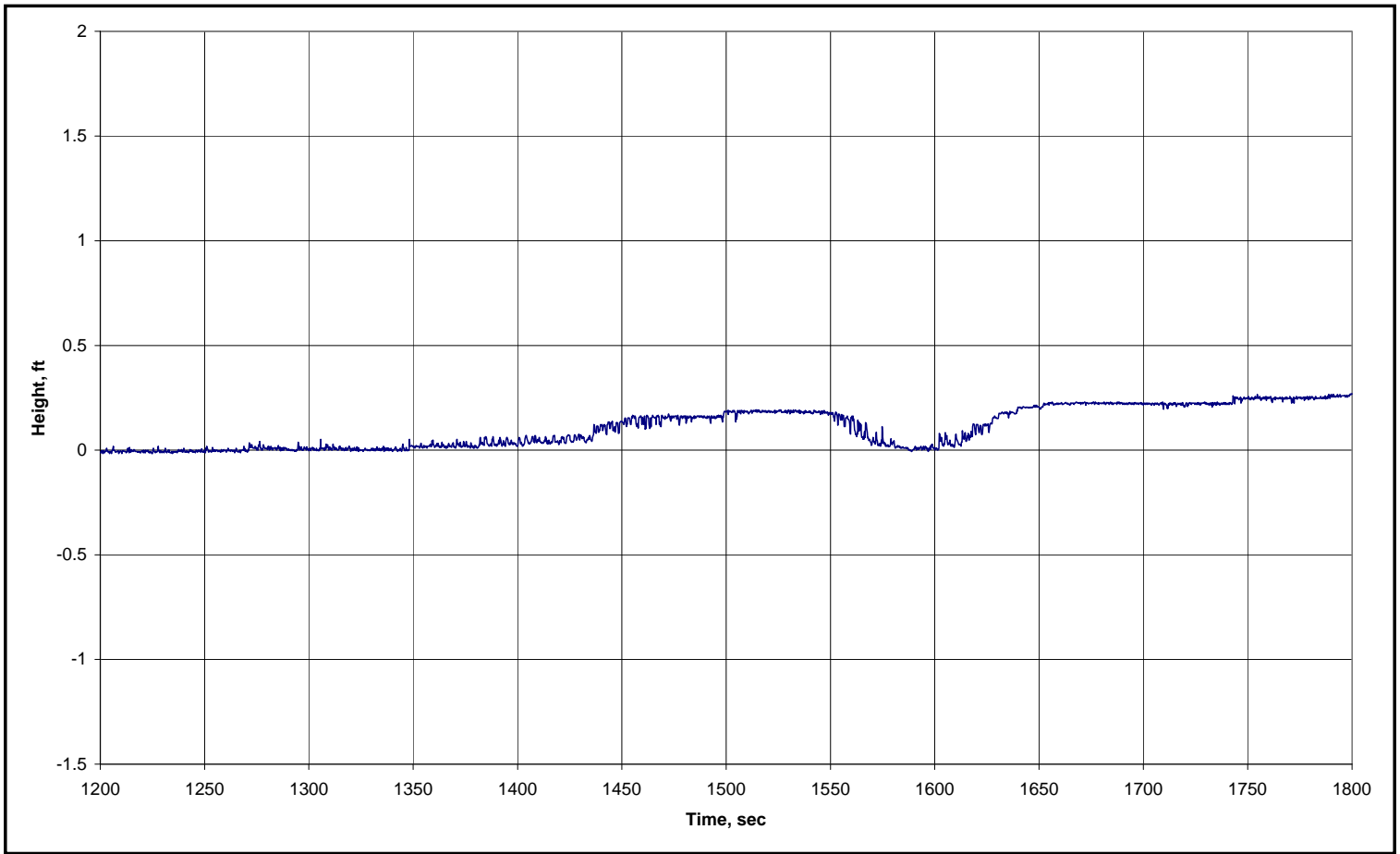

Figure D10. Darya Rani, inbound, time 0 = 1500 EDT, 17 Sep 2005.

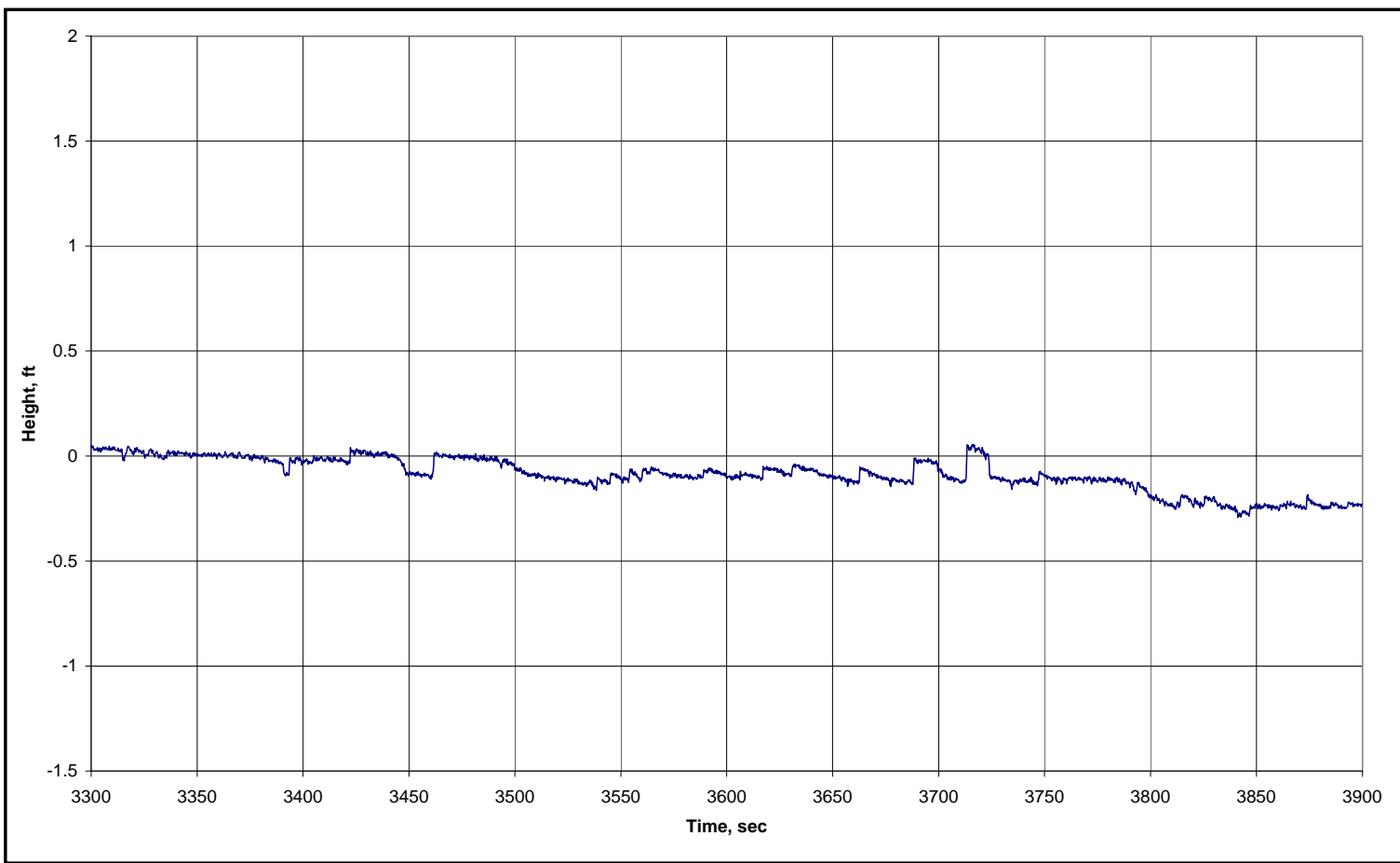

Figure D11. Alyona, inbound, time 0 = 2000 EDT, 17 Sep 2005. 


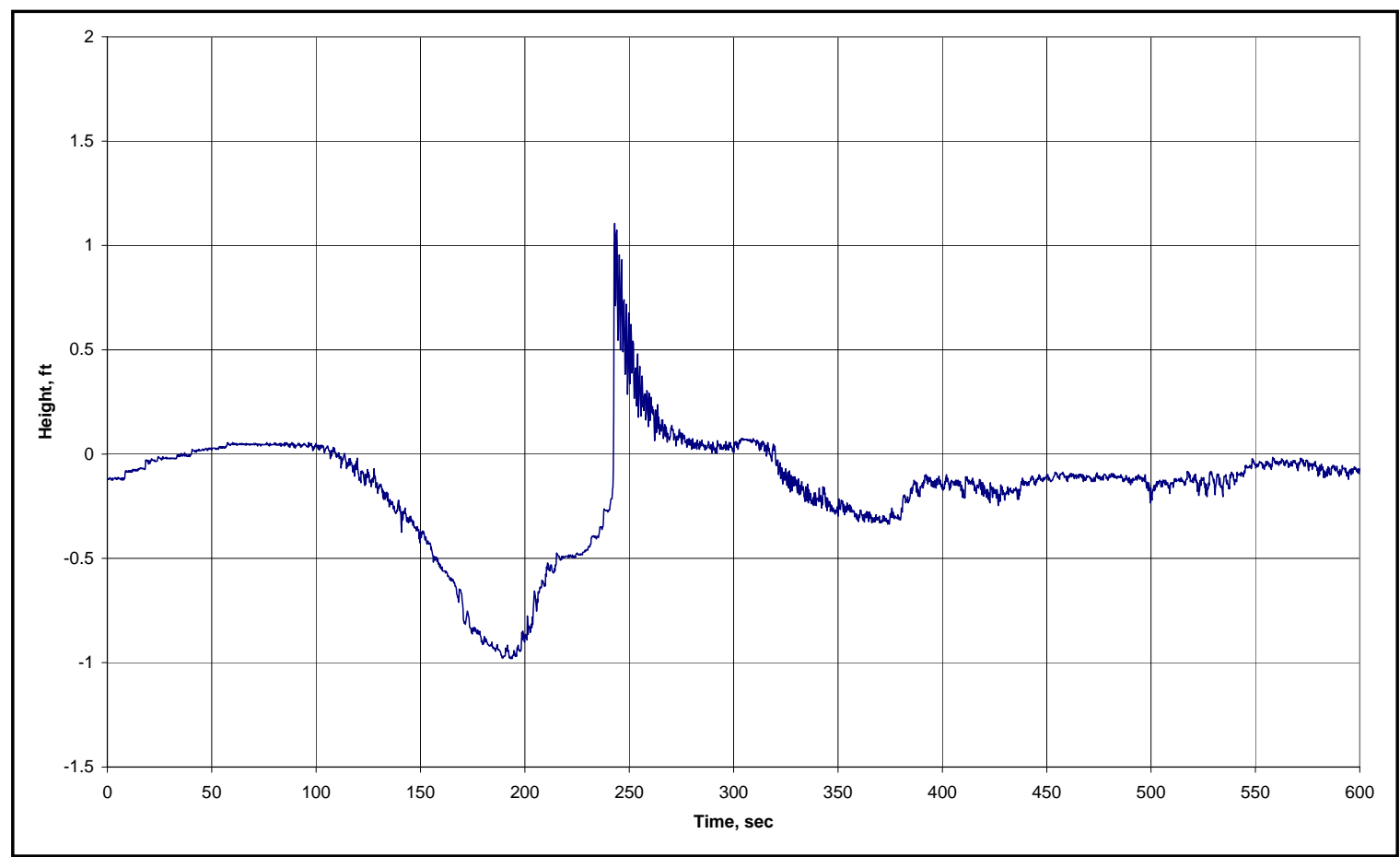

Figure D12. Zim Iberia, inbound, time 0 = 0300 EDT, 18 Sep 2005.

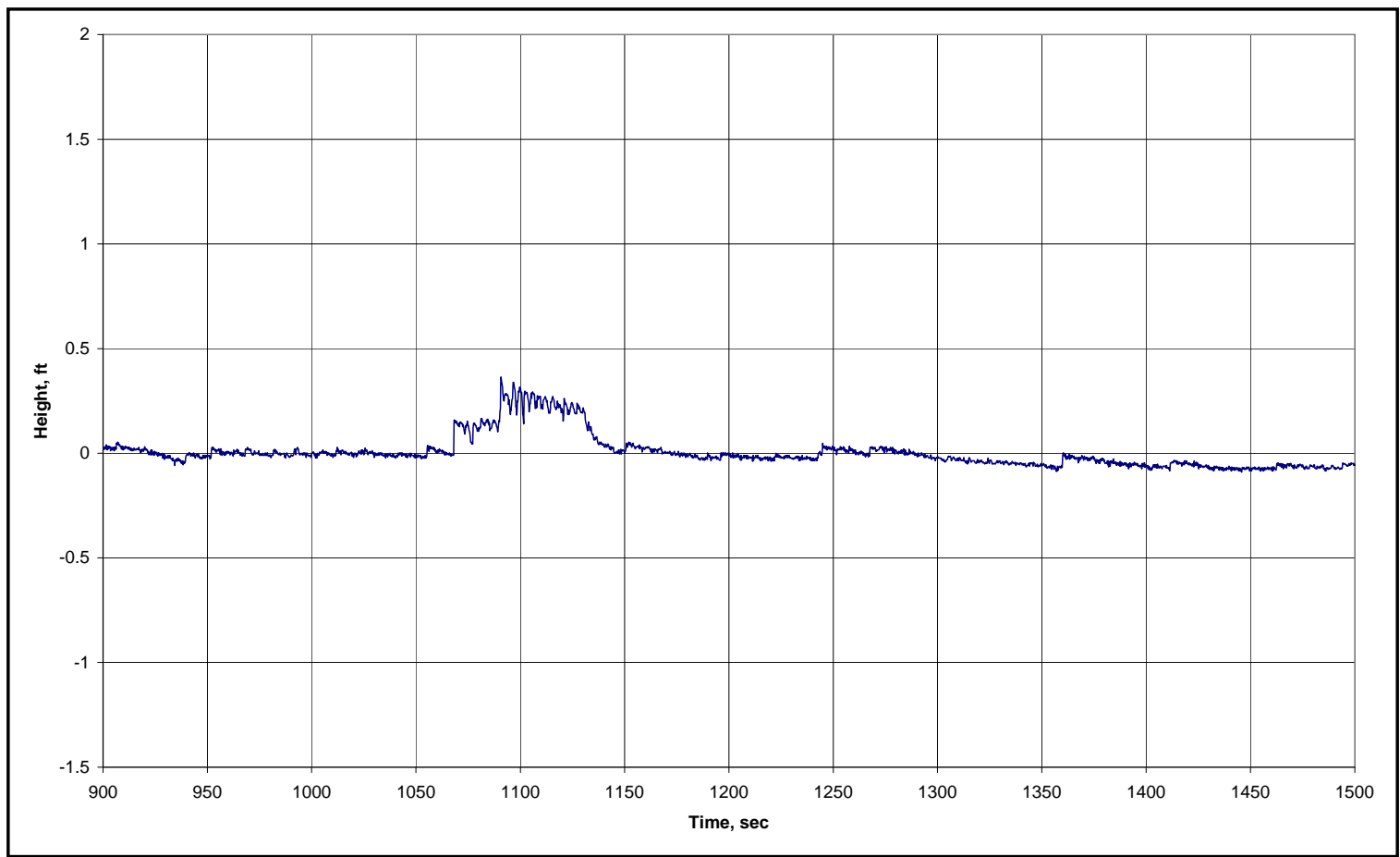

Figure D13. Al Mariyah, inbound, time 0 = 0900 EDT, 18 Sep 2005. 


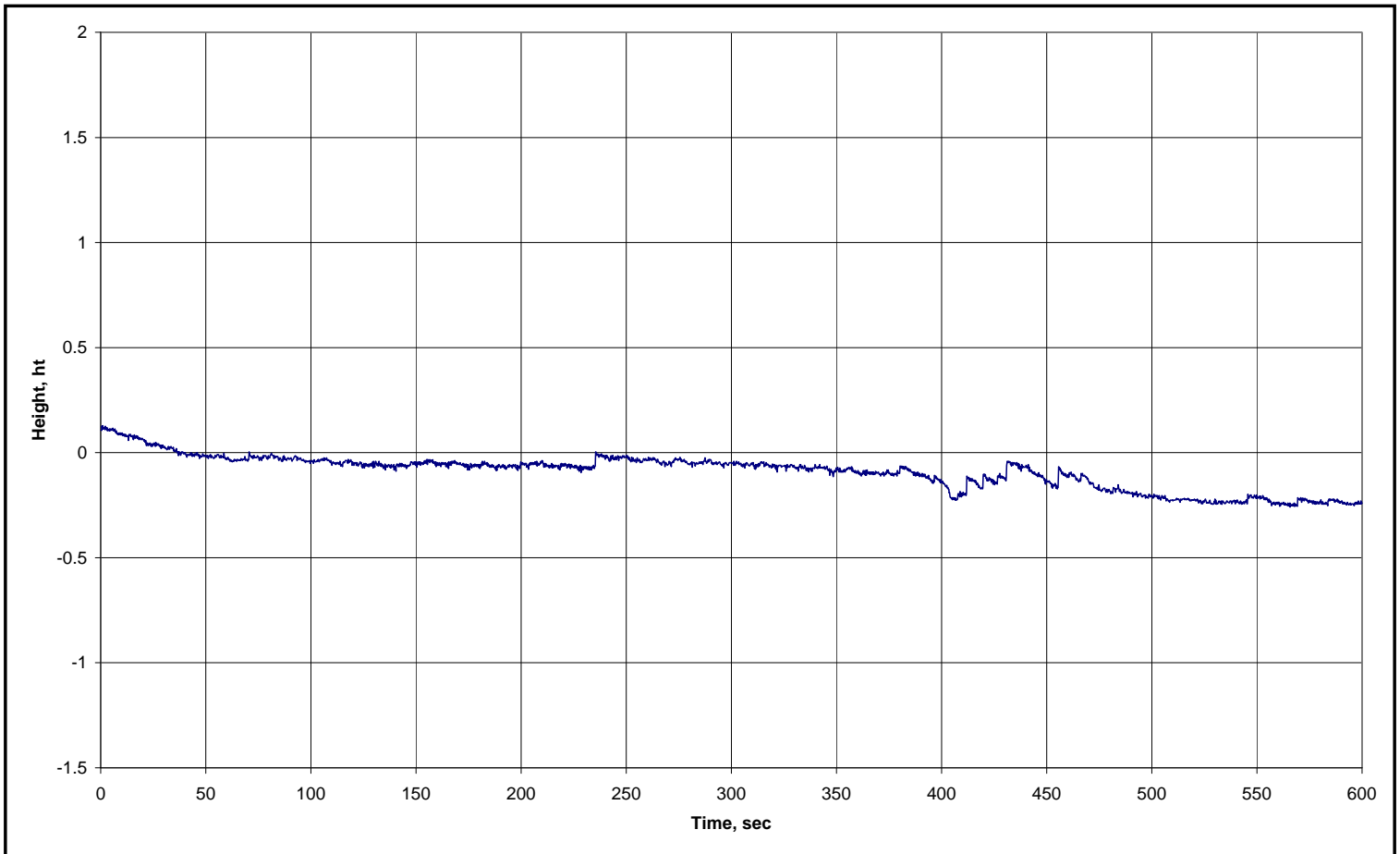

Figure D14. MSC Elena, inbound, time 0 = 1000 EDT, 18 Sep 2005.

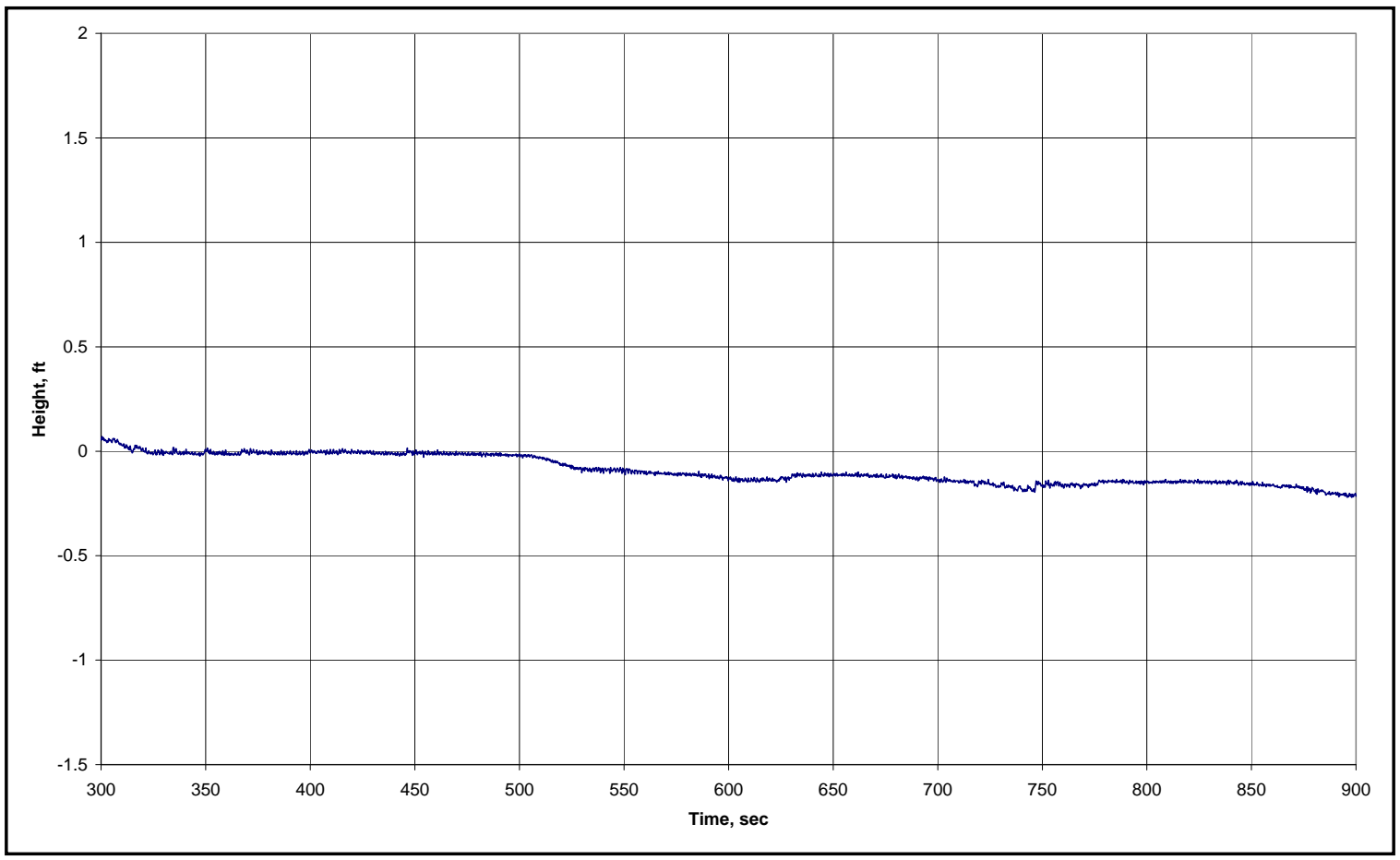

Figure D15. Emanuell Tomassos, inbound, time 0 = 1300 EDT, 18 Sep 2005. 


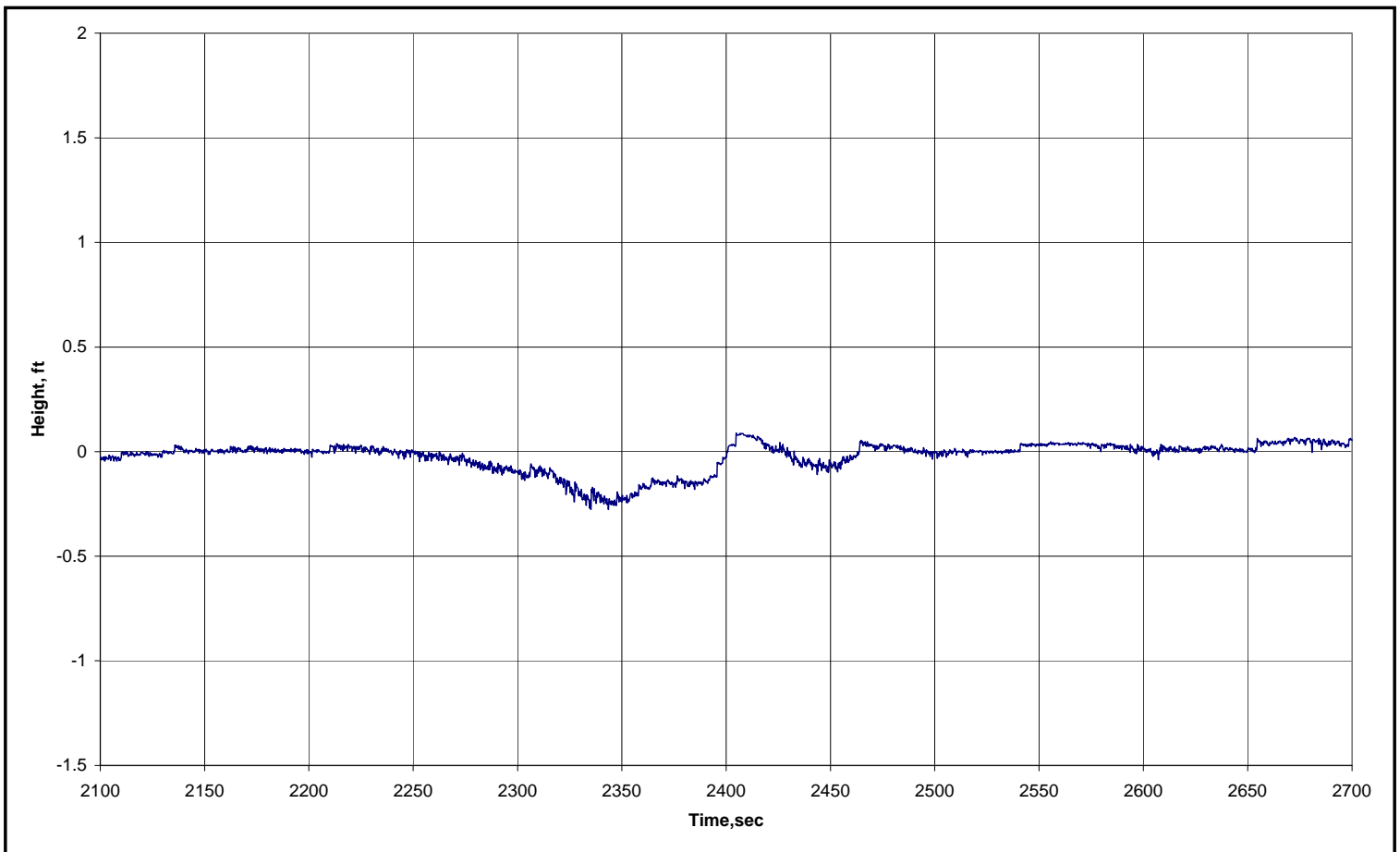

Figure D16. Hanjin Wilmington, inbound, time 0 = 1500 EDT, 18 Sep 2005.

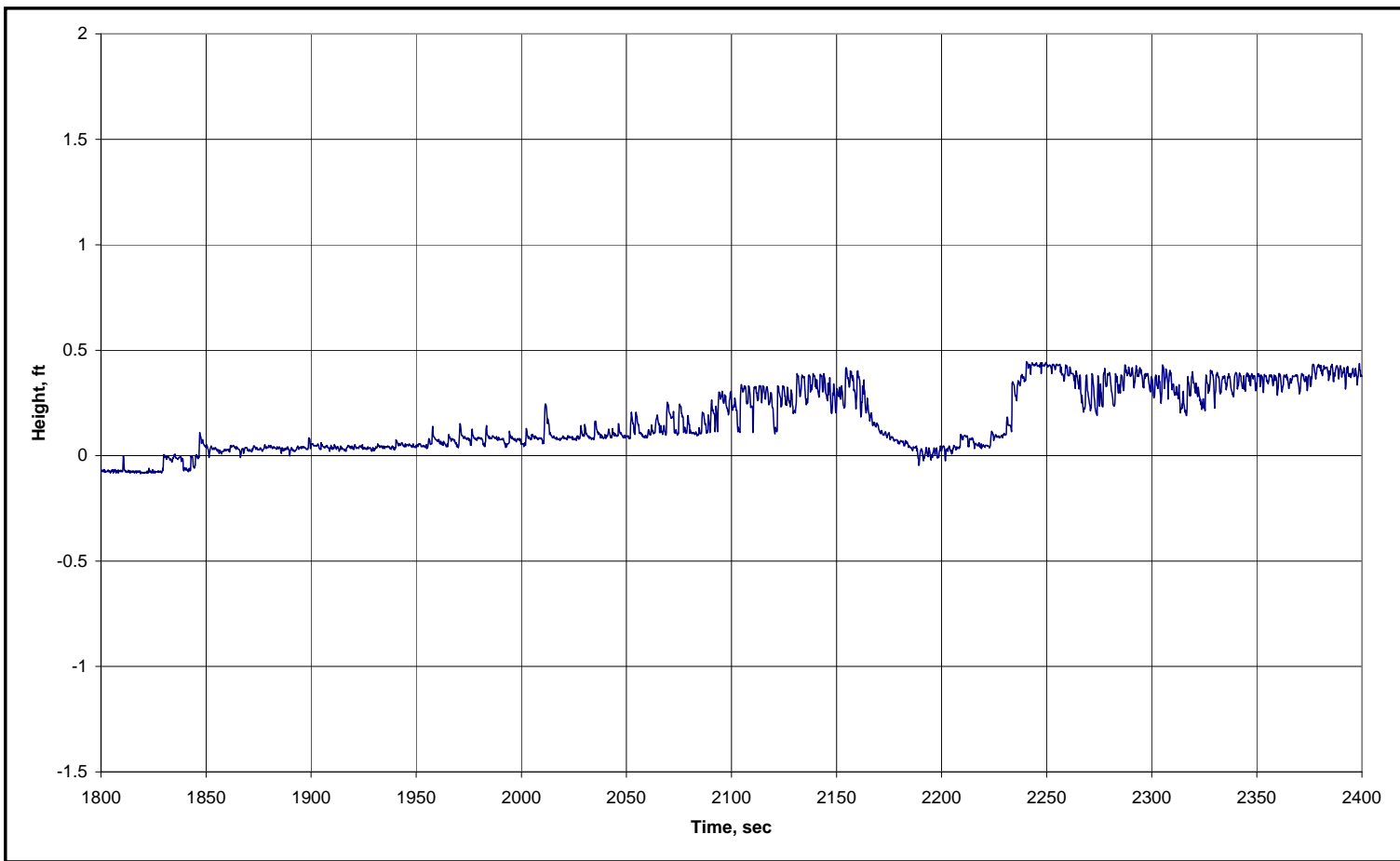

Figure D17. Condor, inbound, time 0 = 1700 EDT, 18 Sep 2005. 


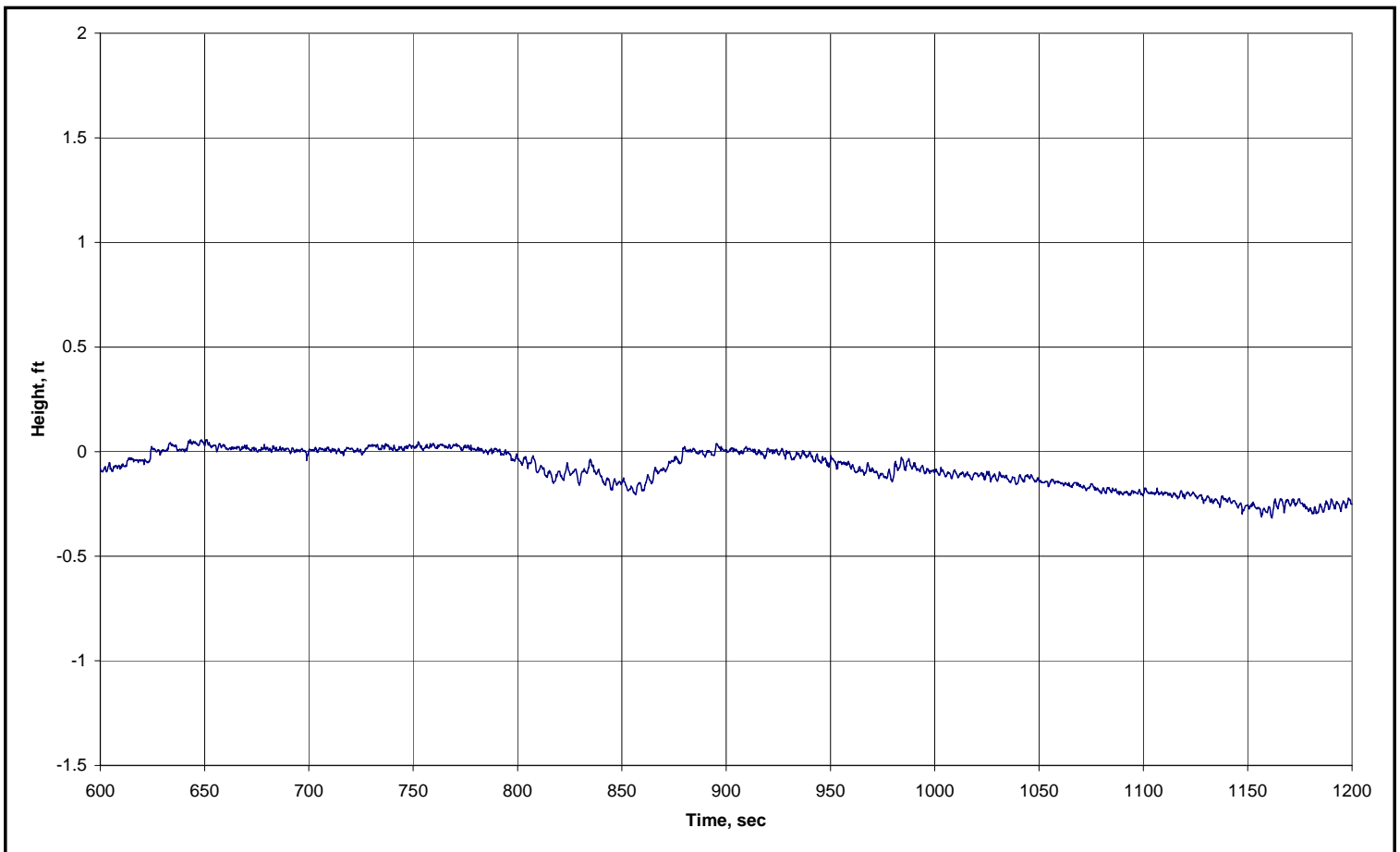

Figure D18. Victoria Bridge, inbound, time 0 = 2300 EDT, 18 Sep 2005.

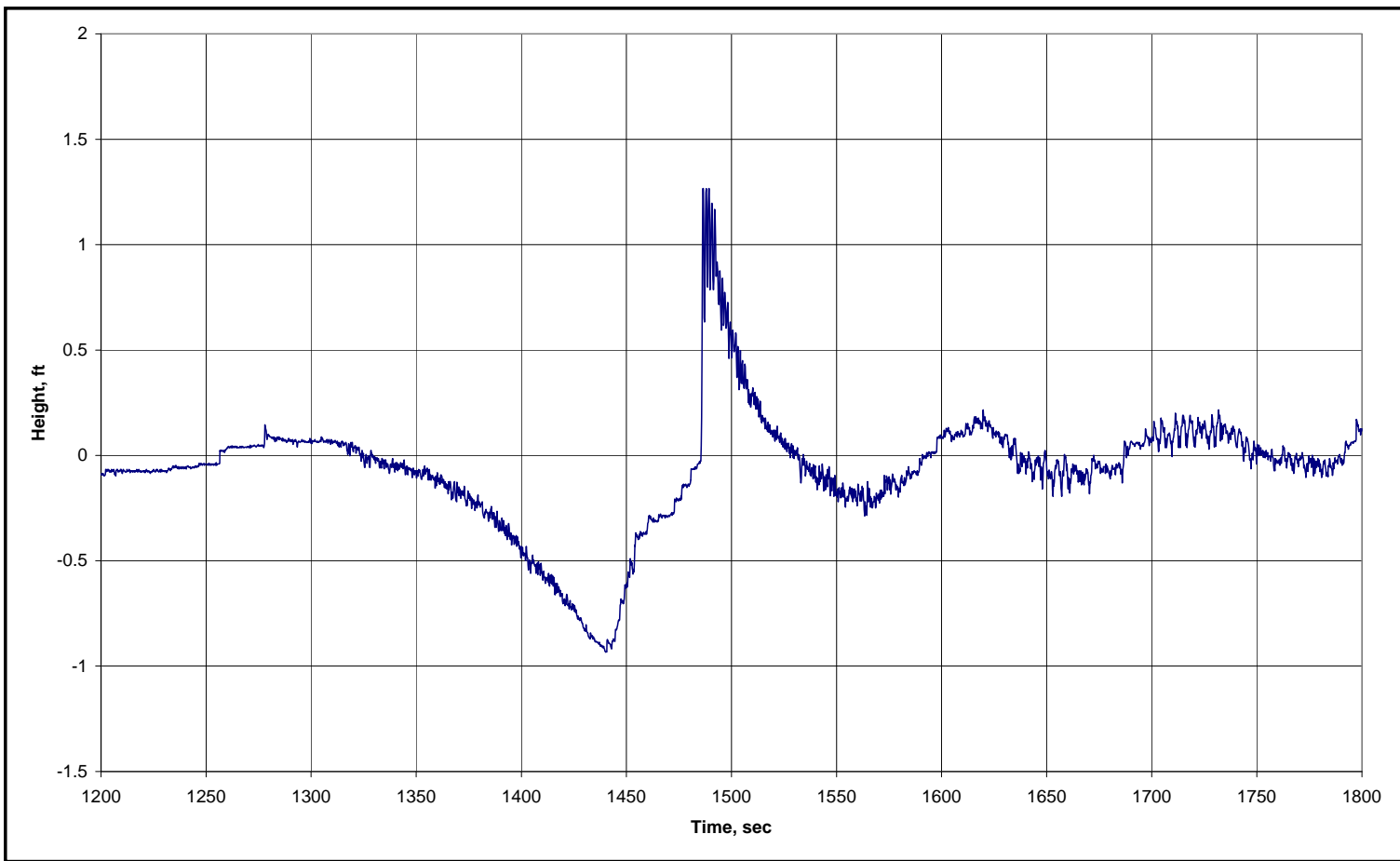

Figure D19. Essen Express, inbound, time 0 = 0400 EDT, 19 Sep 2005. 


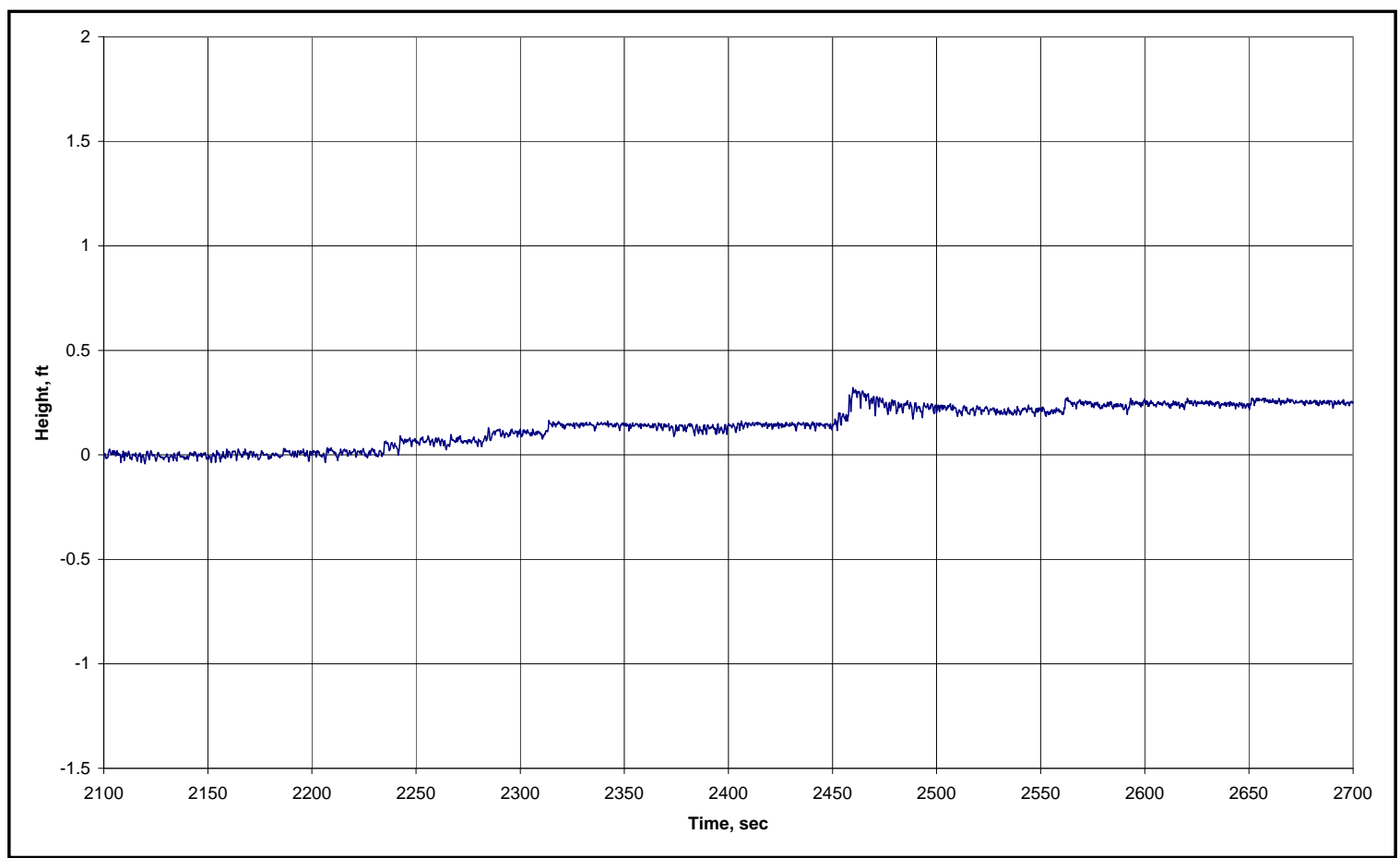

Figure D20. Kavo Alexandros II, inbound, time 0 = 0700 EDT, 19 Sep 2005.

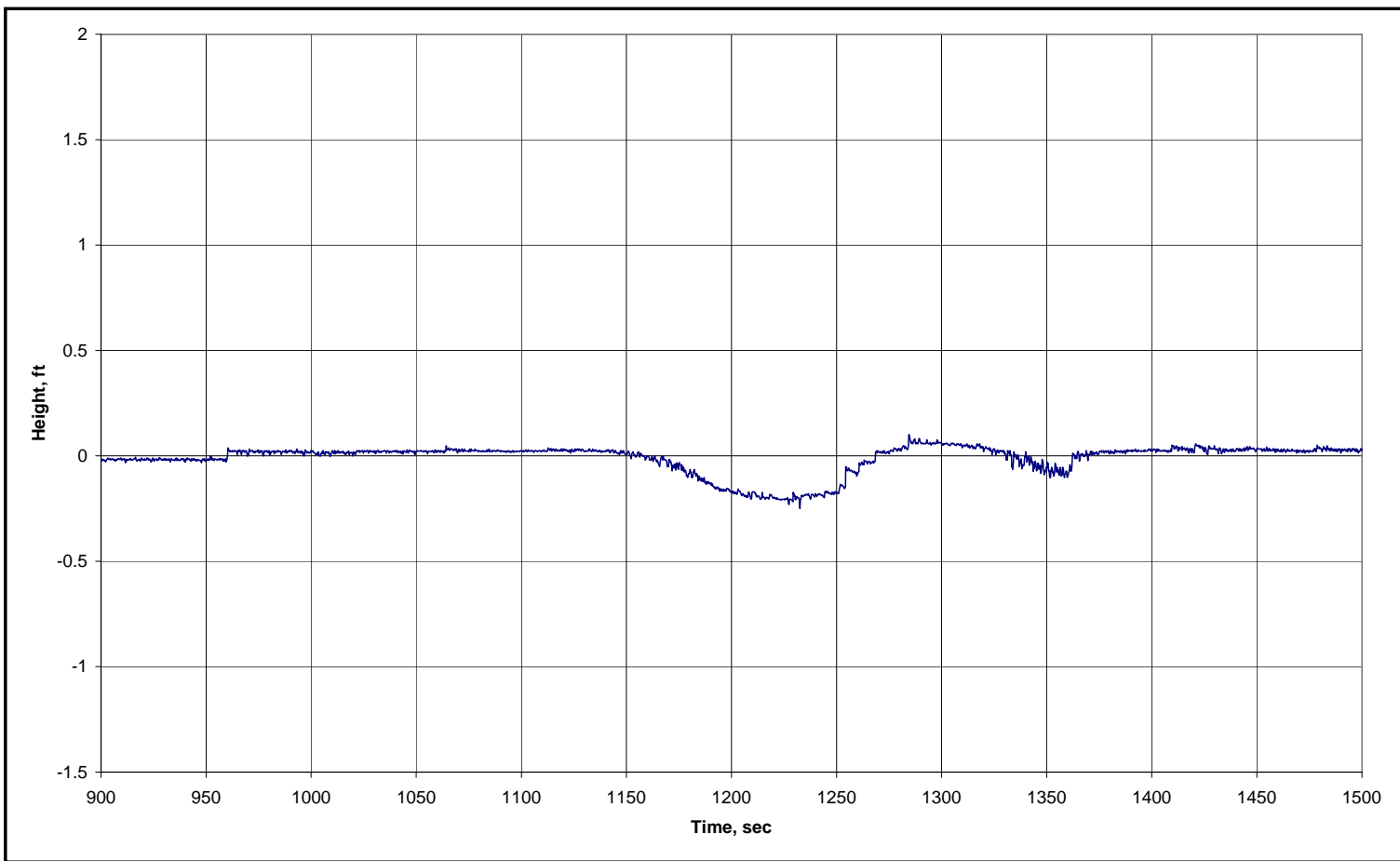

Figure D21. Angel Accord, inbound, time 0 = 1600 EDT, 19 Sep 2005. 


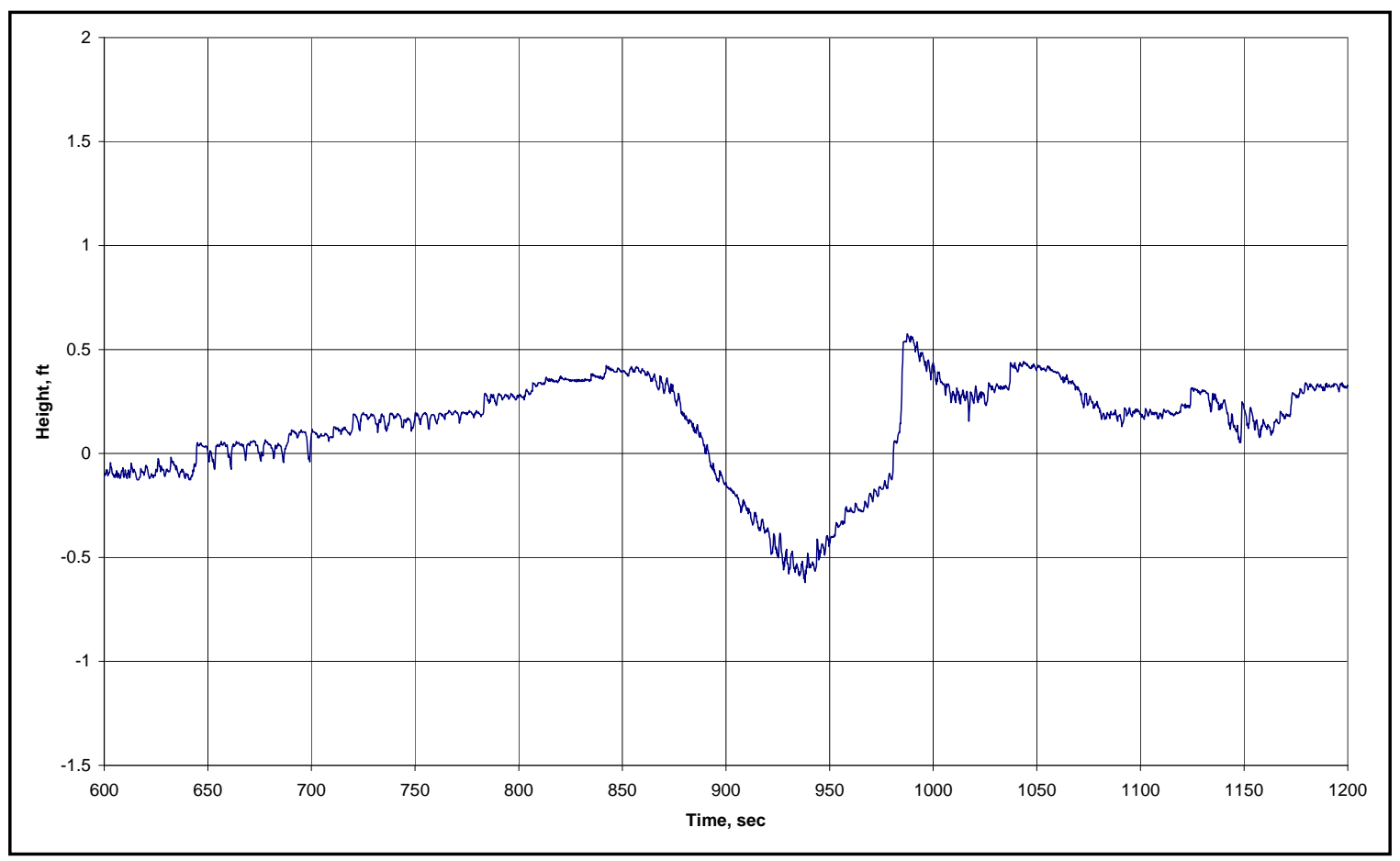

Figure D22. Mol Velocity, inbound, time 0 = 1700 EDT, 19 Sep 2005.

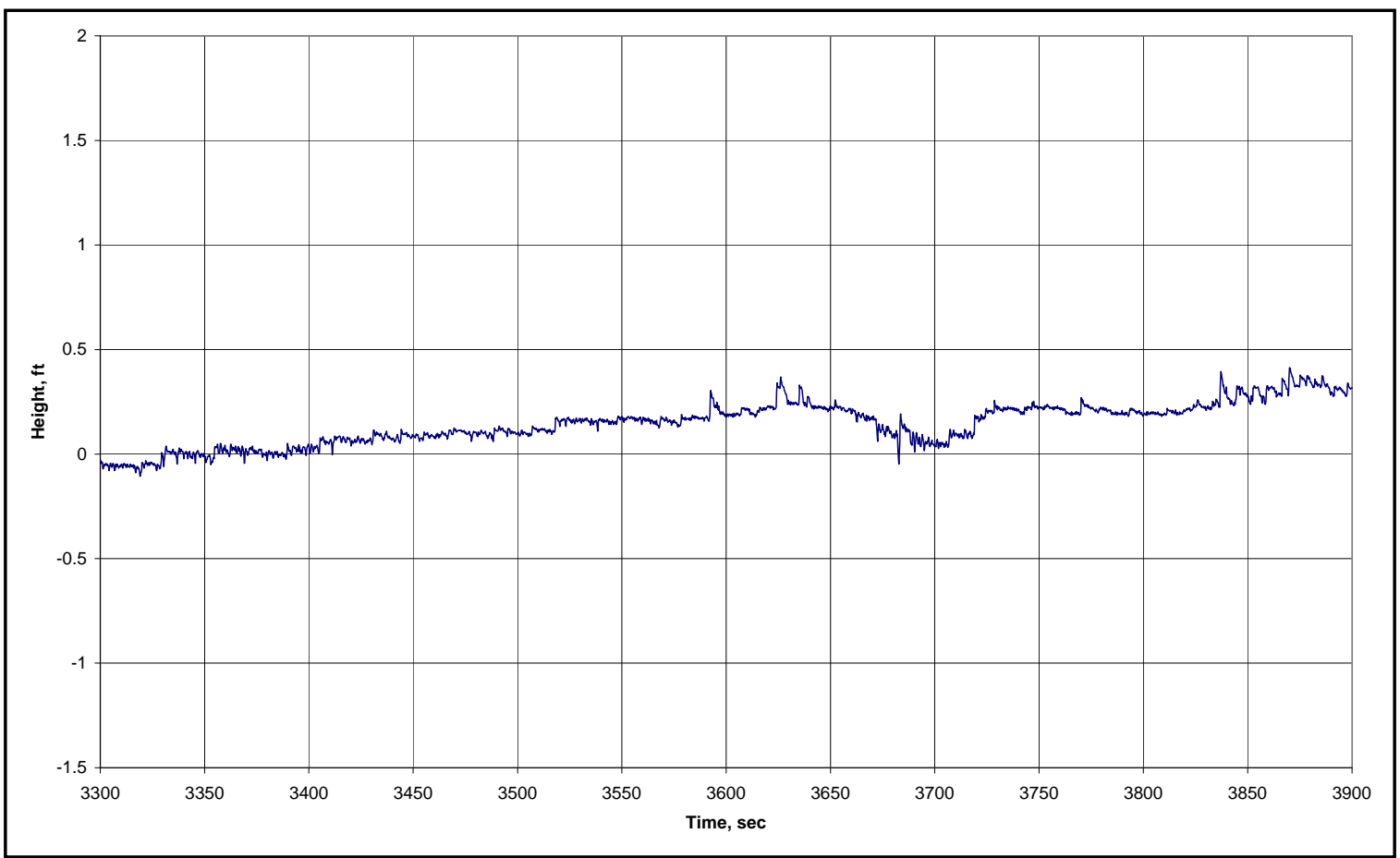

Figure D23. Jervis Bay, inbound, time 0 = 1800, 19 Sep 2005. 


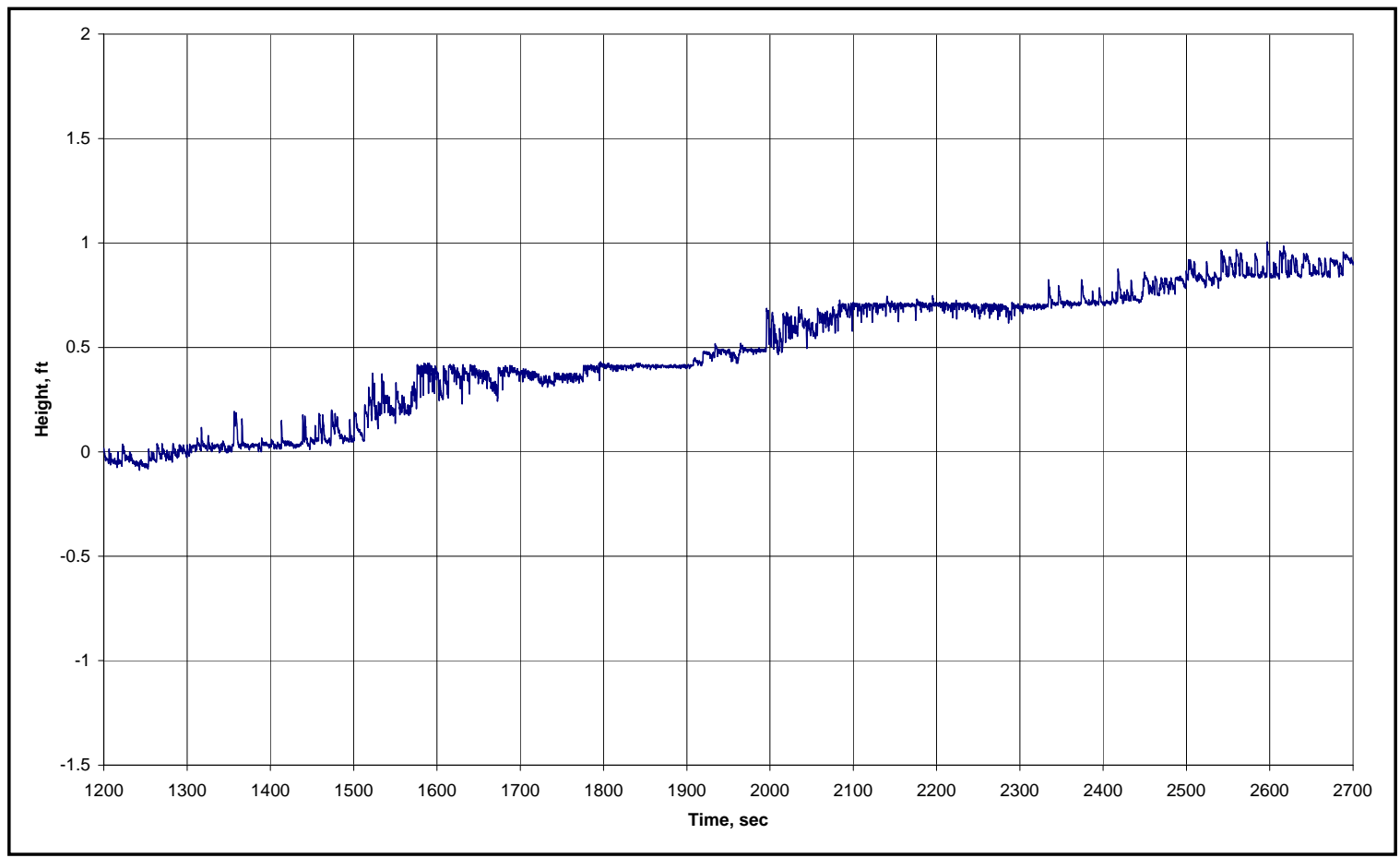

Figure D24. Borc, inbound, time 0 = 1800 EDT, 19 Sep 2005.

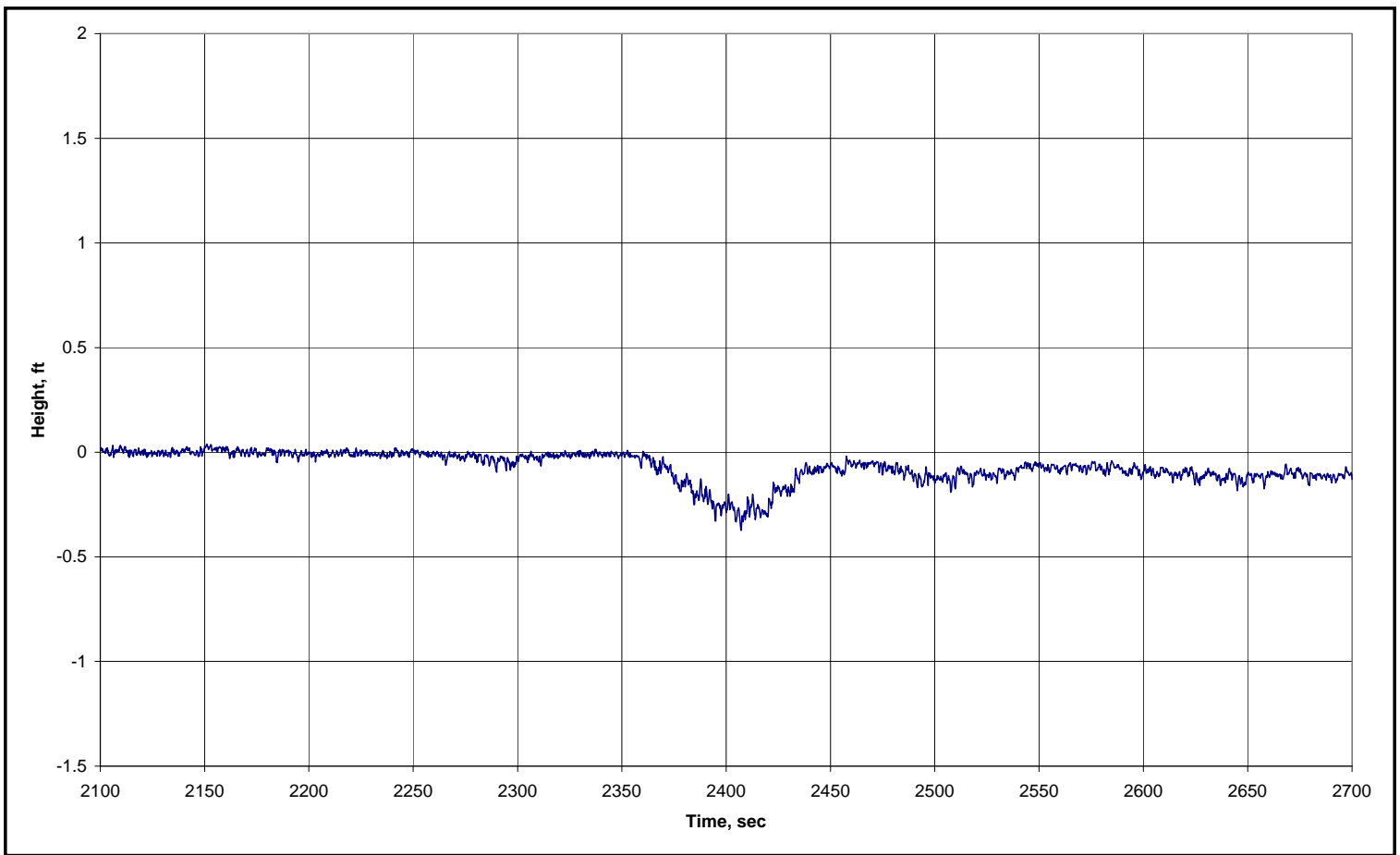

Figure D25. Stuttgart Express, inbound, time $0=2200$ EDT, 19 Sep 2005. 


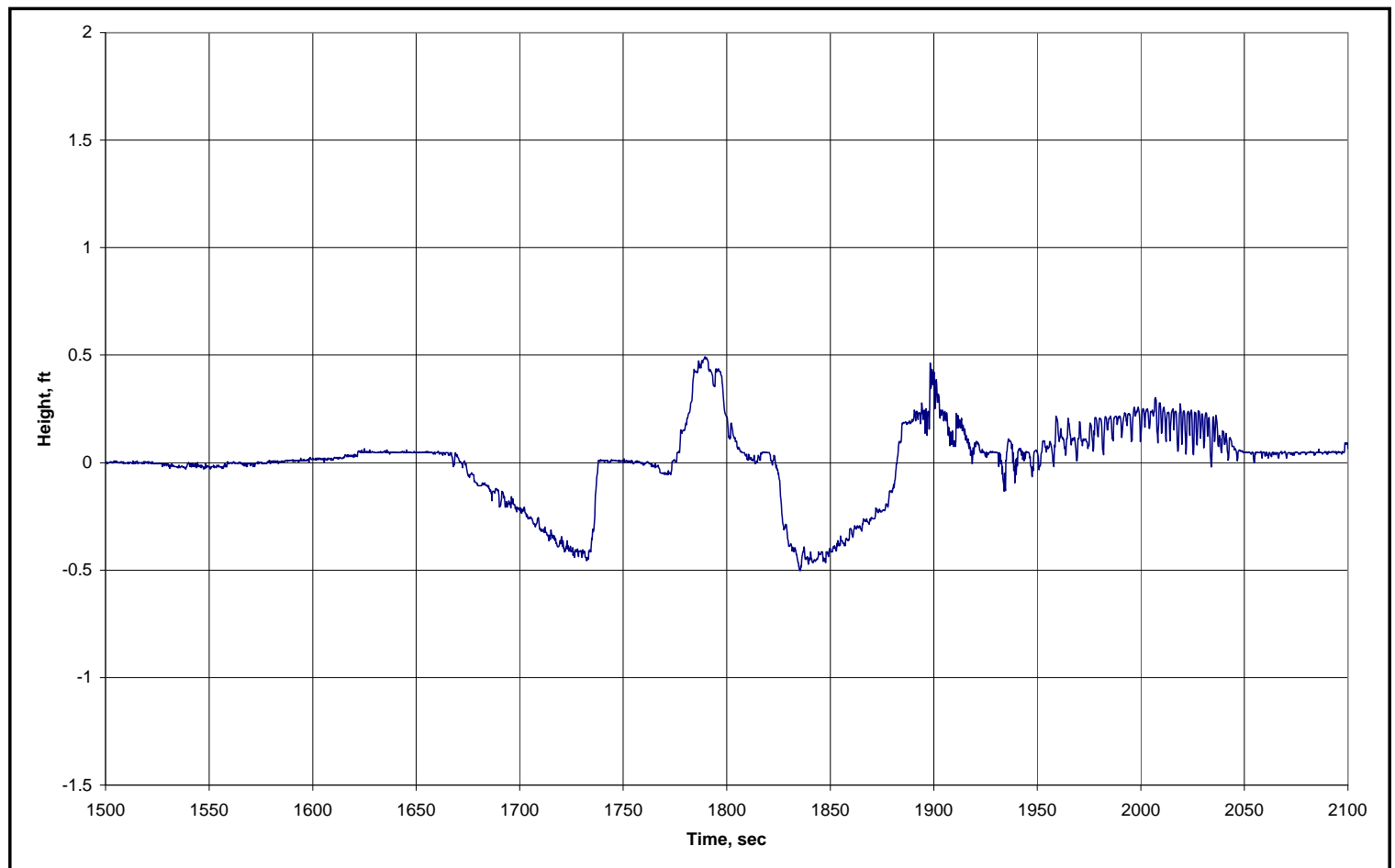

Figure D26. Khannur, outbound, time 0 = 1300 EDT, 16 Sep 2005.

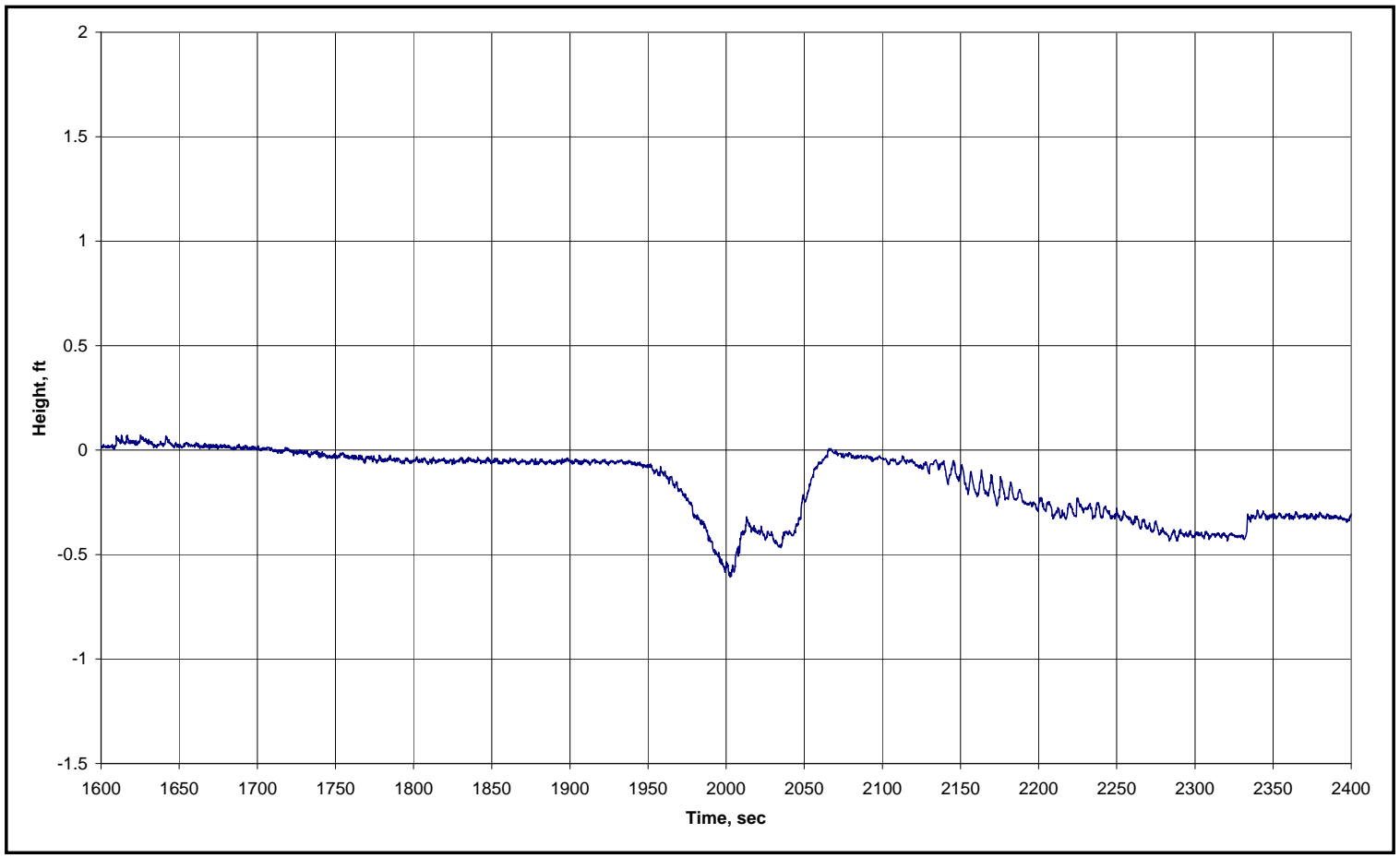

Figure D27. YM South, outbound, time 0 = 2100 EDT, 16 Sep 2005. 


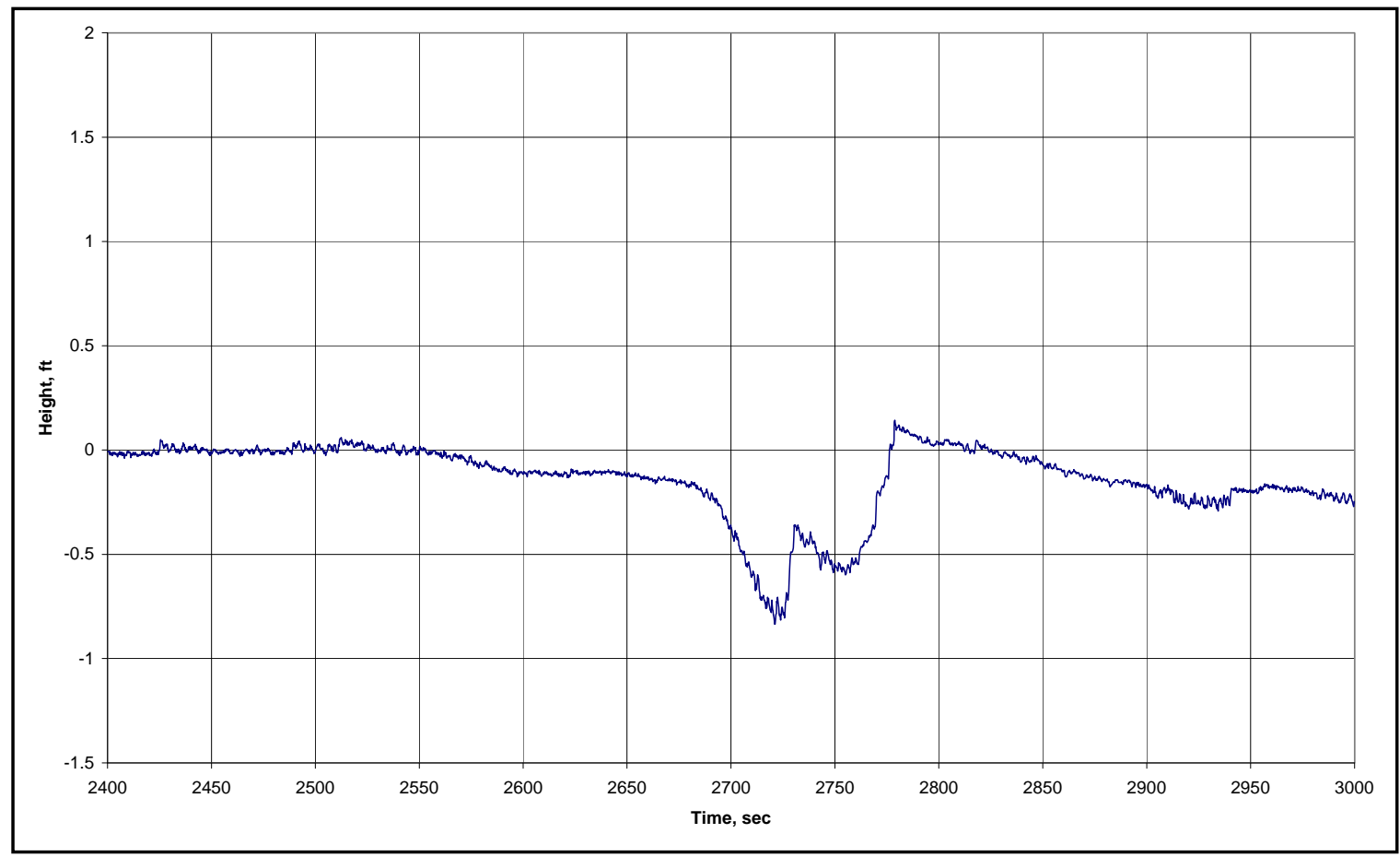

Figure D28. Maersk Garonne, outbound, time 0 = 2100 EDT, 16 Sep 2005.

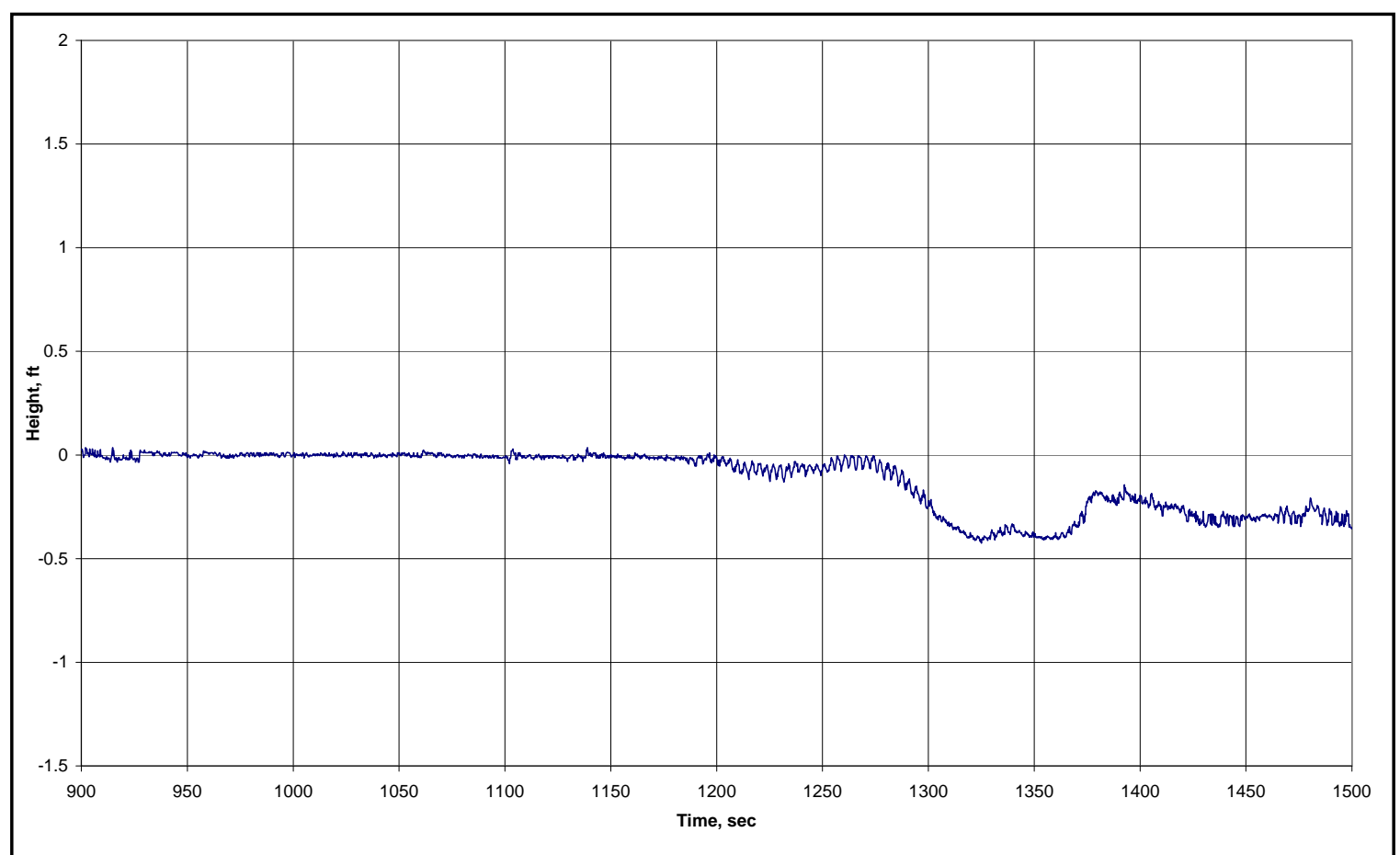

Figure D29. Star Drivanger, outbound, time 0 = 2200 EDT, 16 Sep 2005. 


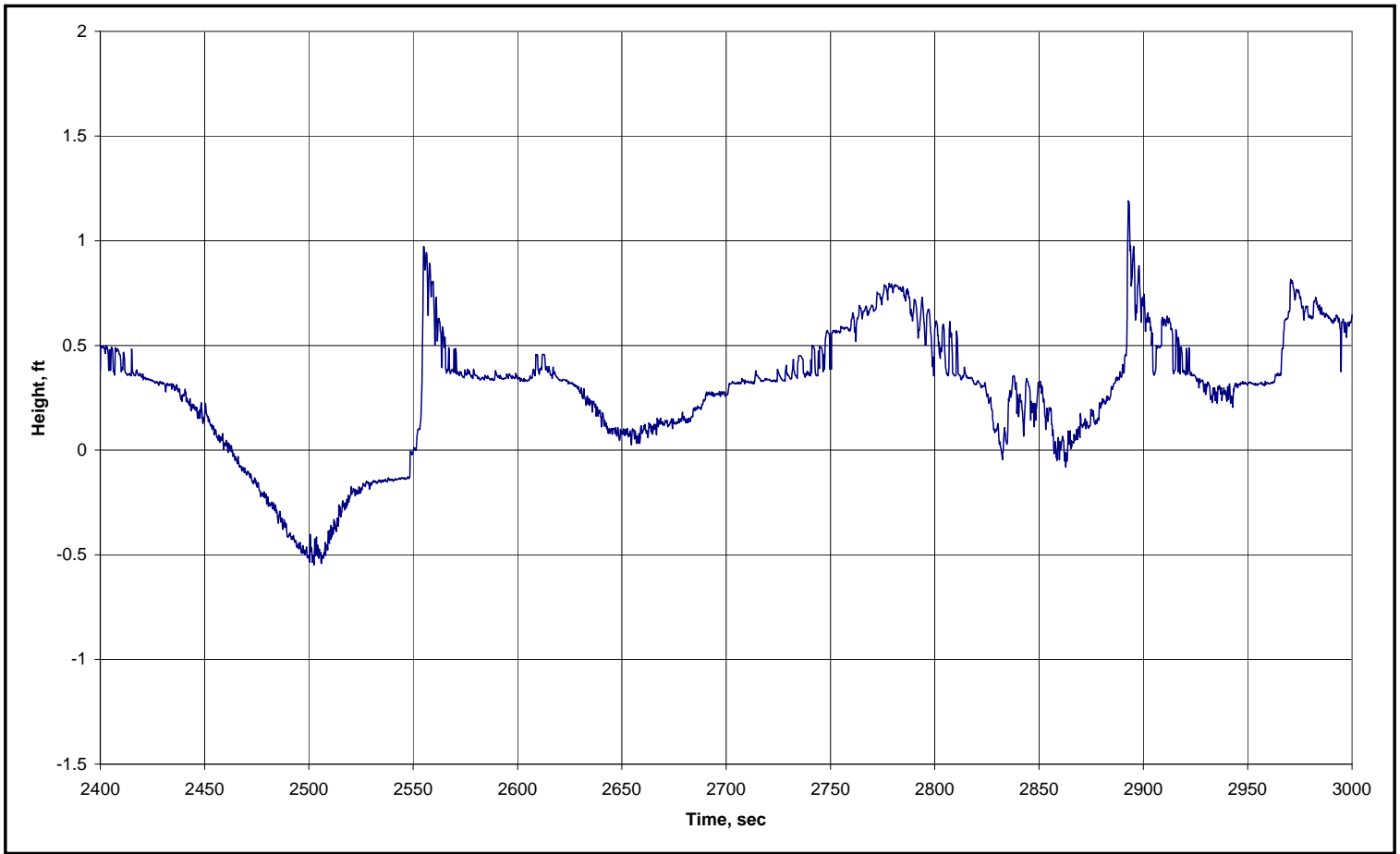

Figure D30. Leyla Kalkavan, outbound, time 0 = 0200 EDT, 17 Sep 2005.

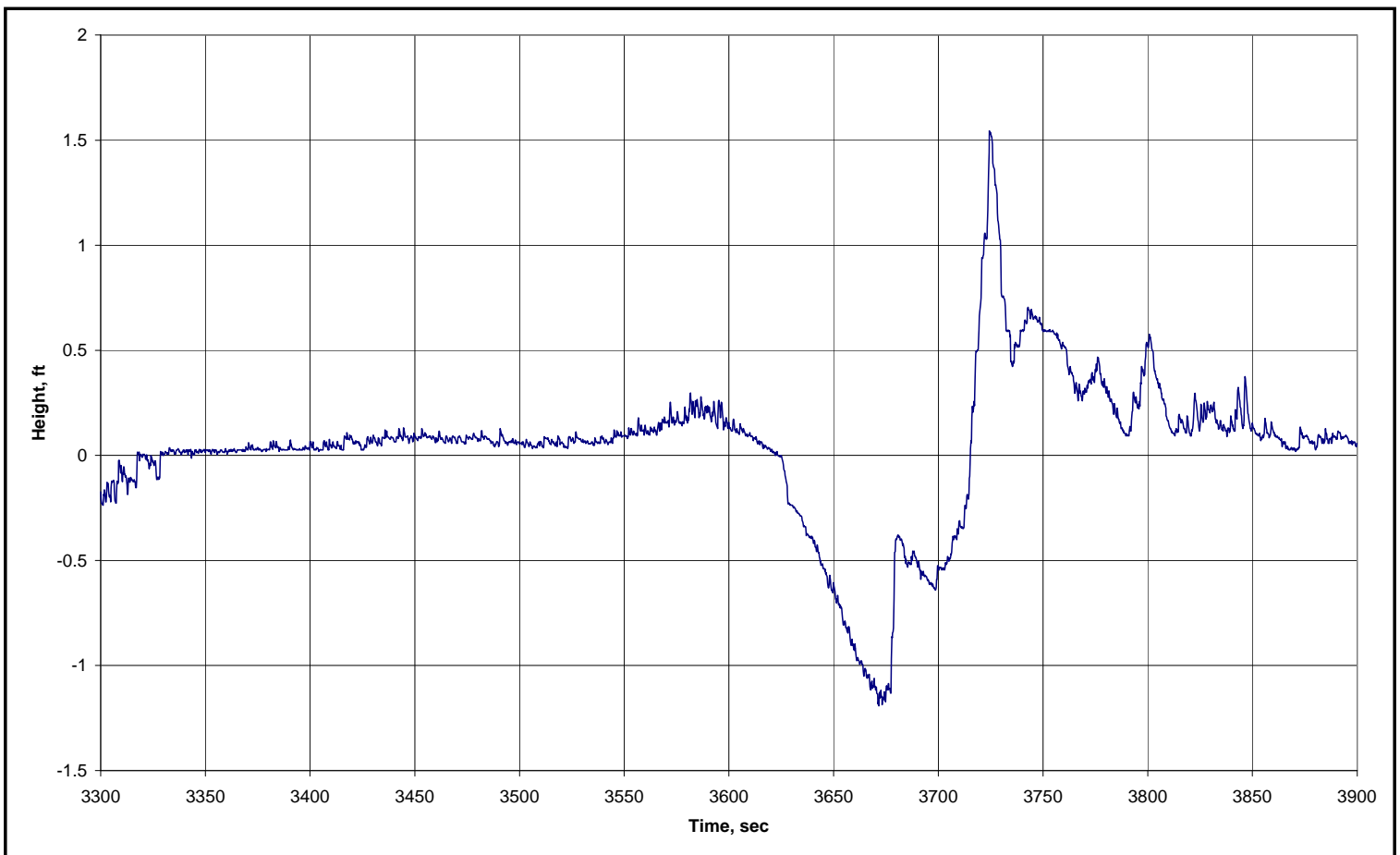

Figure D31. New York Express, outbound, time 0 = 0300 EDT, 17 Sep 2005. 
ERDC/CHL TR-07-7

128

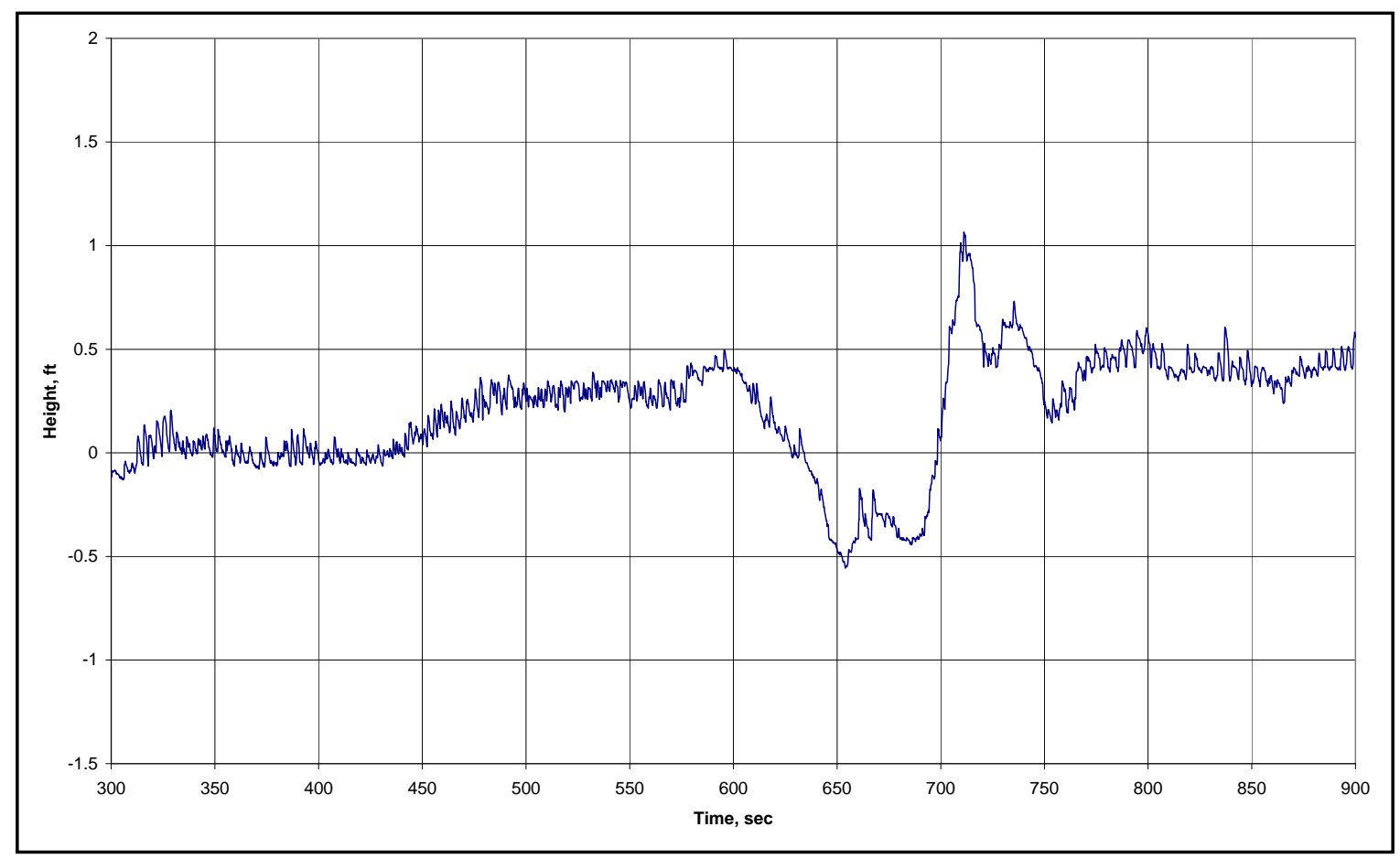

Figure D32. Star Florida, outbound, time 0 = 0400 EDT, 17 Sep 2005.

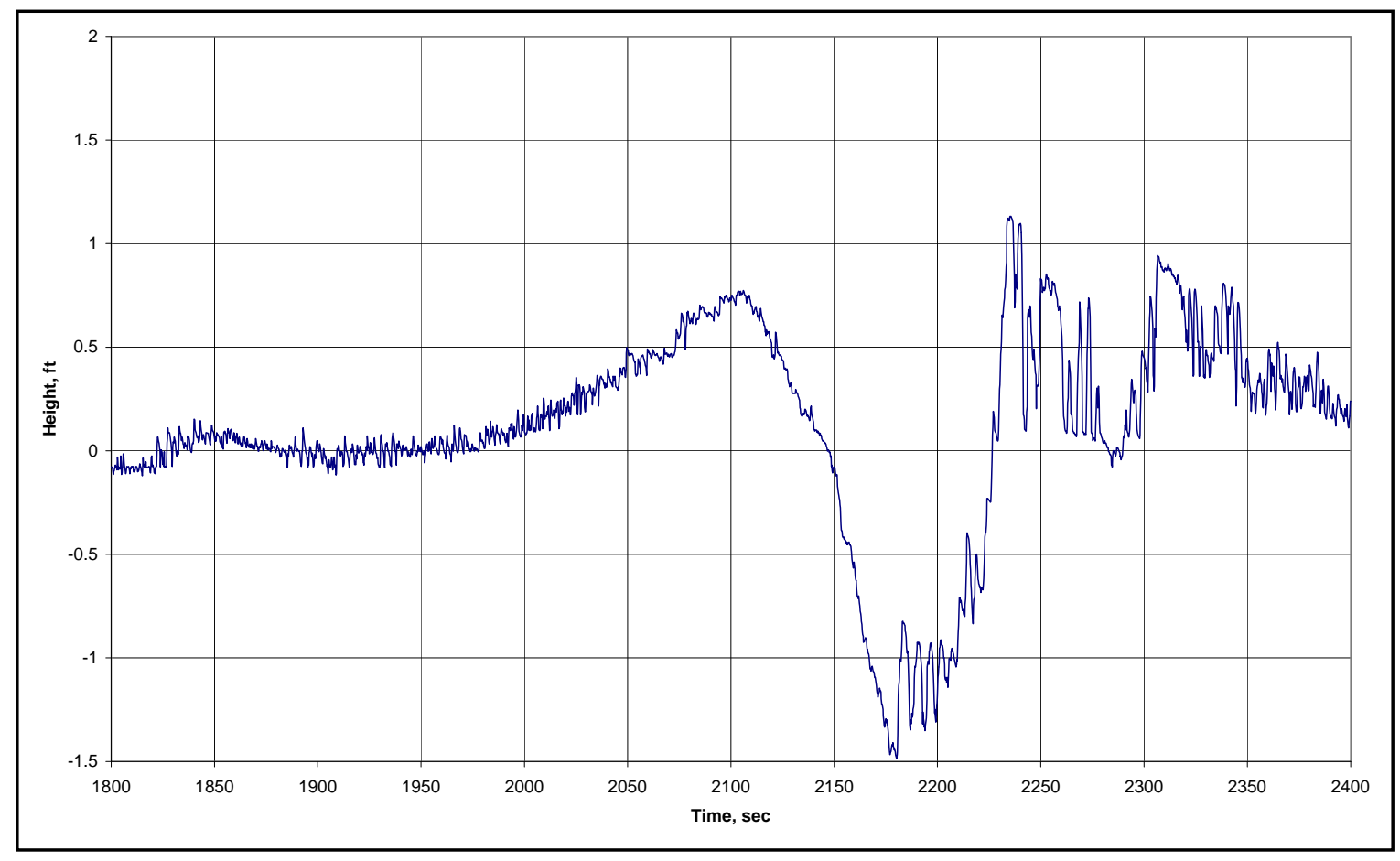

Figure D33. Sens Maersk, outbound, time 0 = 0400 EDT, 17 Sep 2005. 
ERDC/CHL TR-07-7

129

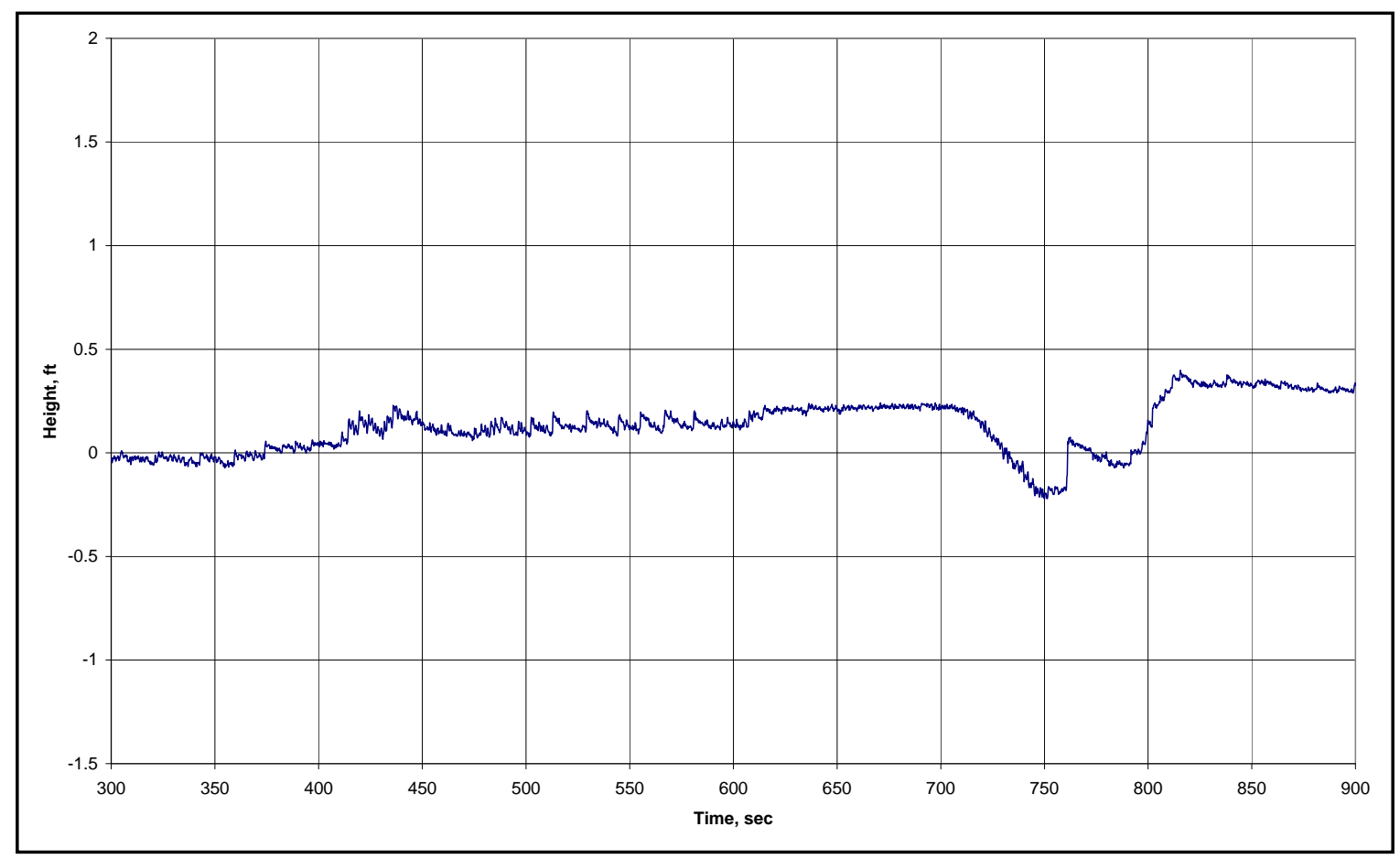

Figure D34. Kyriakoula, outbound, time 0 = 0600 EDT, 17 Sep 2005.

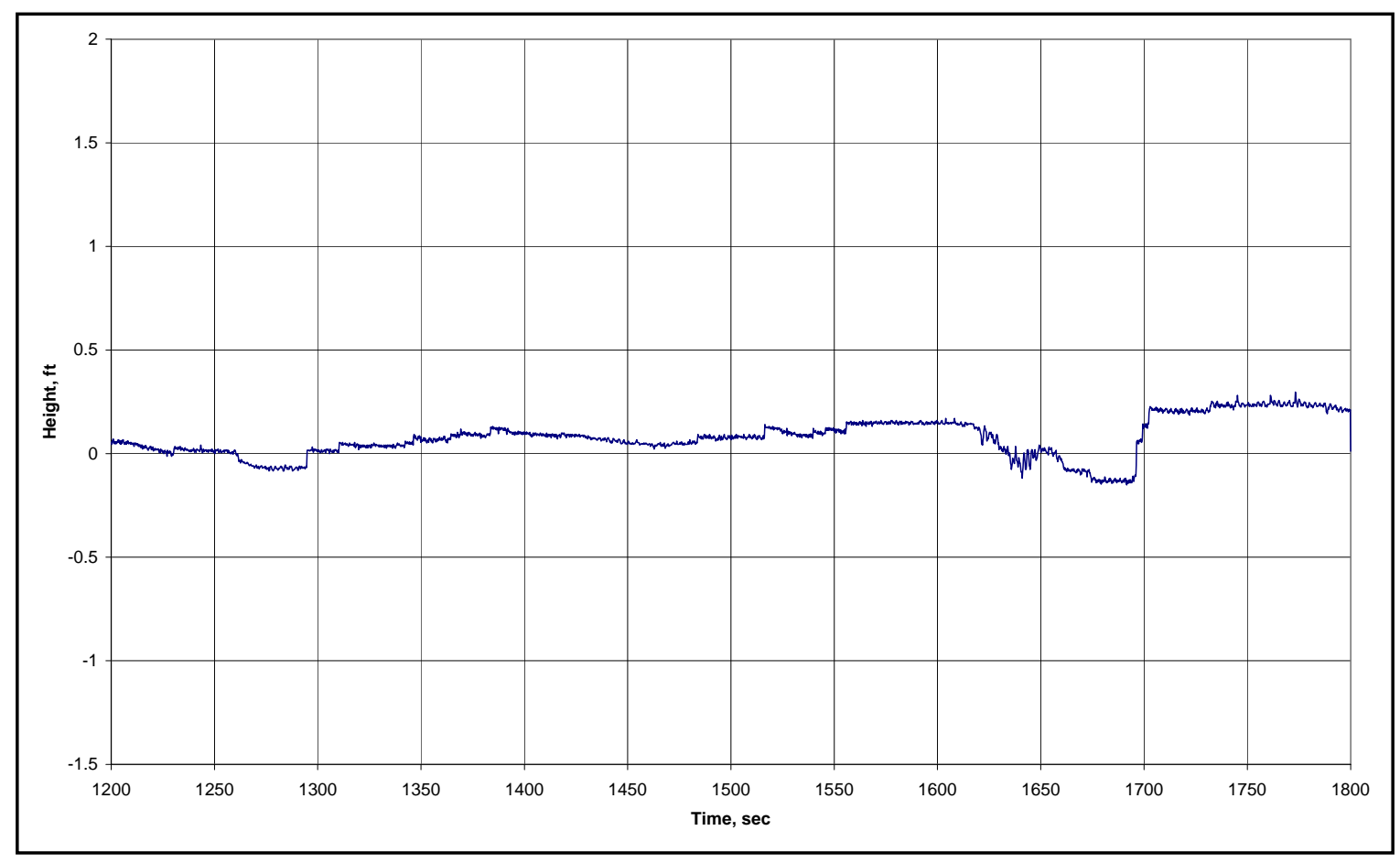

Figure D35. Mol America, outbound, time 0 = 0800 EDT, 17 Sep 2005. 


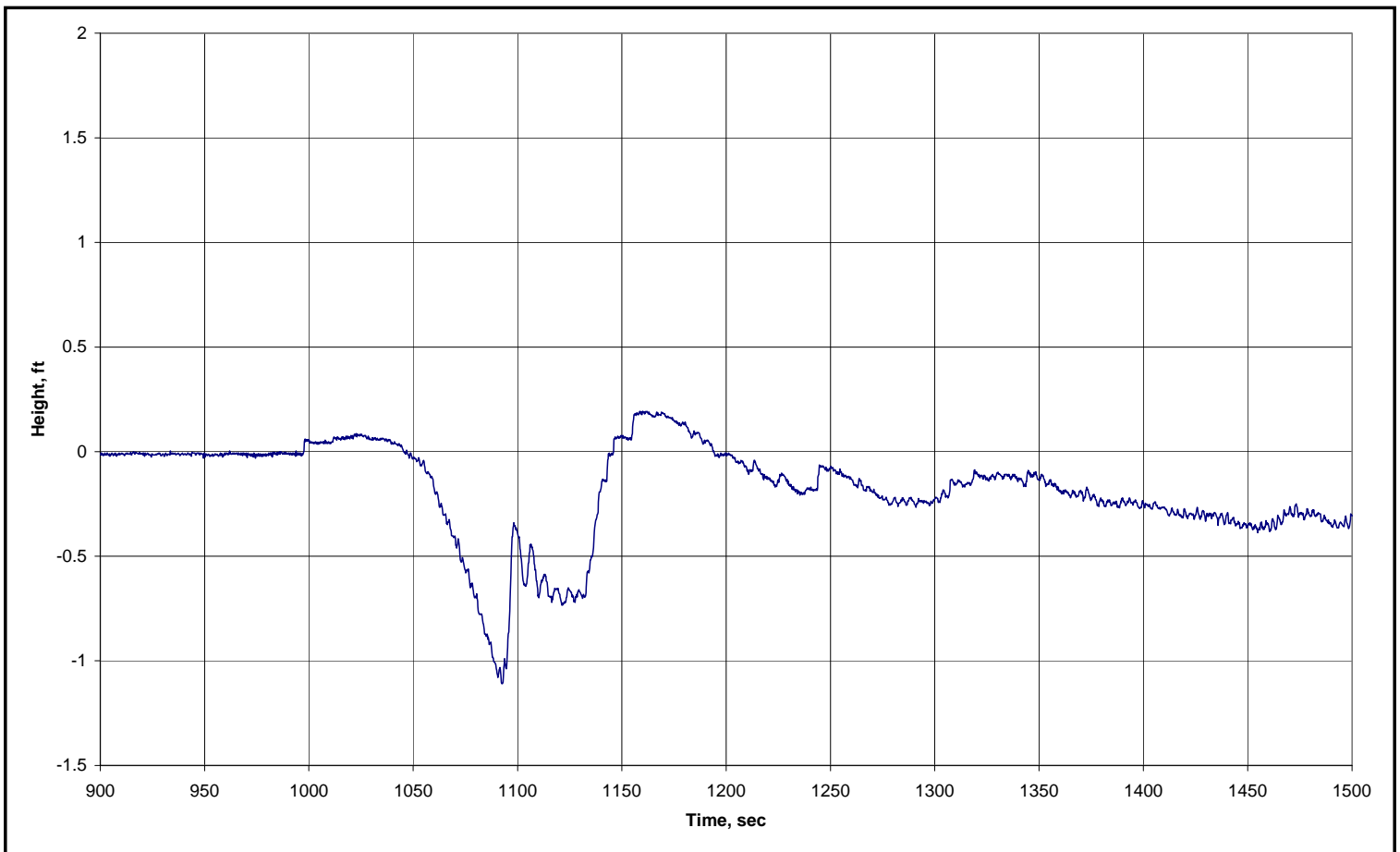

Figure D36. Sun Right, outbound, time 0 = 1000 EDT, 17 Sep 2005.

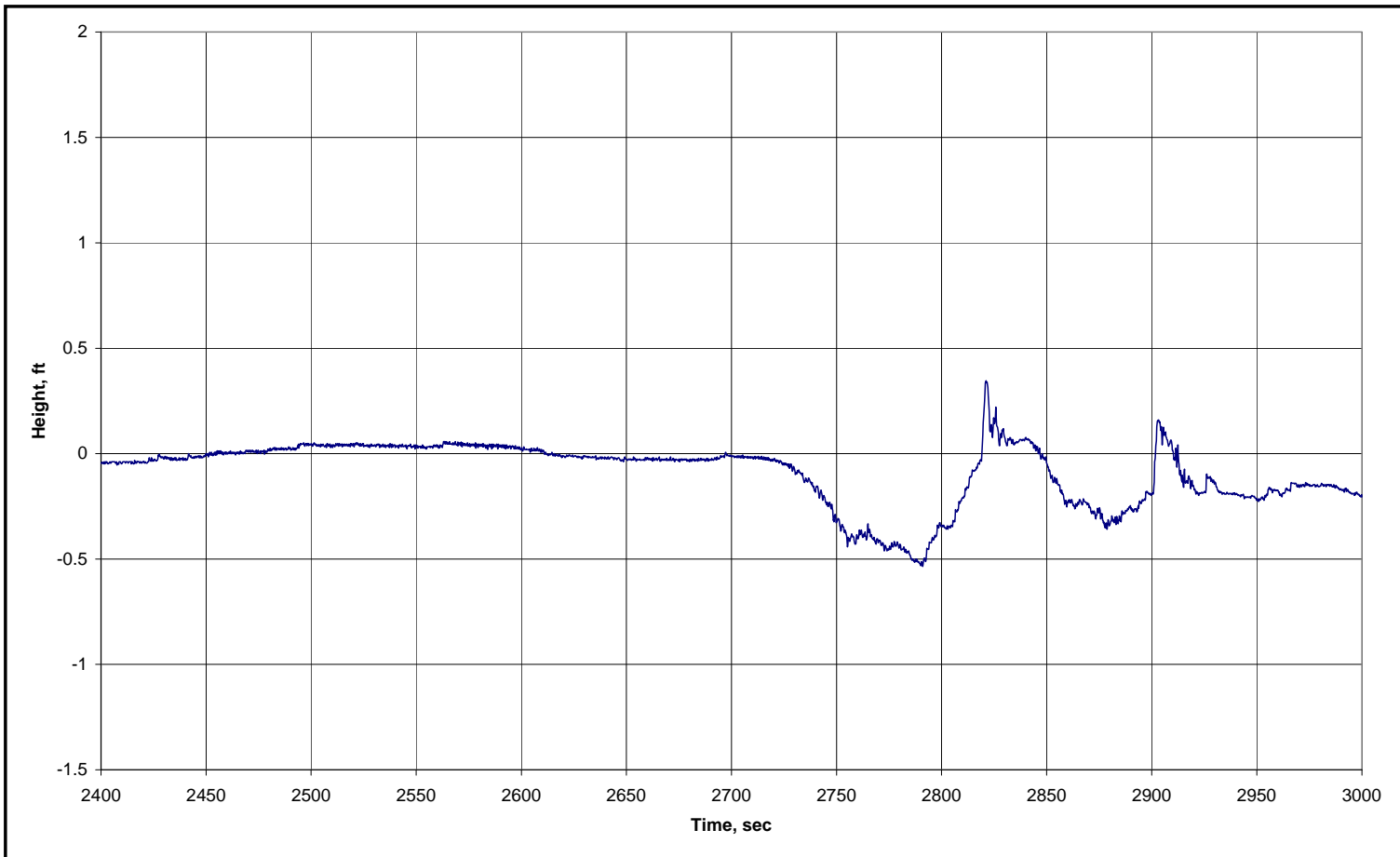

Figure D37. CMA CGM Potomoc, outbound, time 0 = 1200 EDT, 17 Sep 2005. 


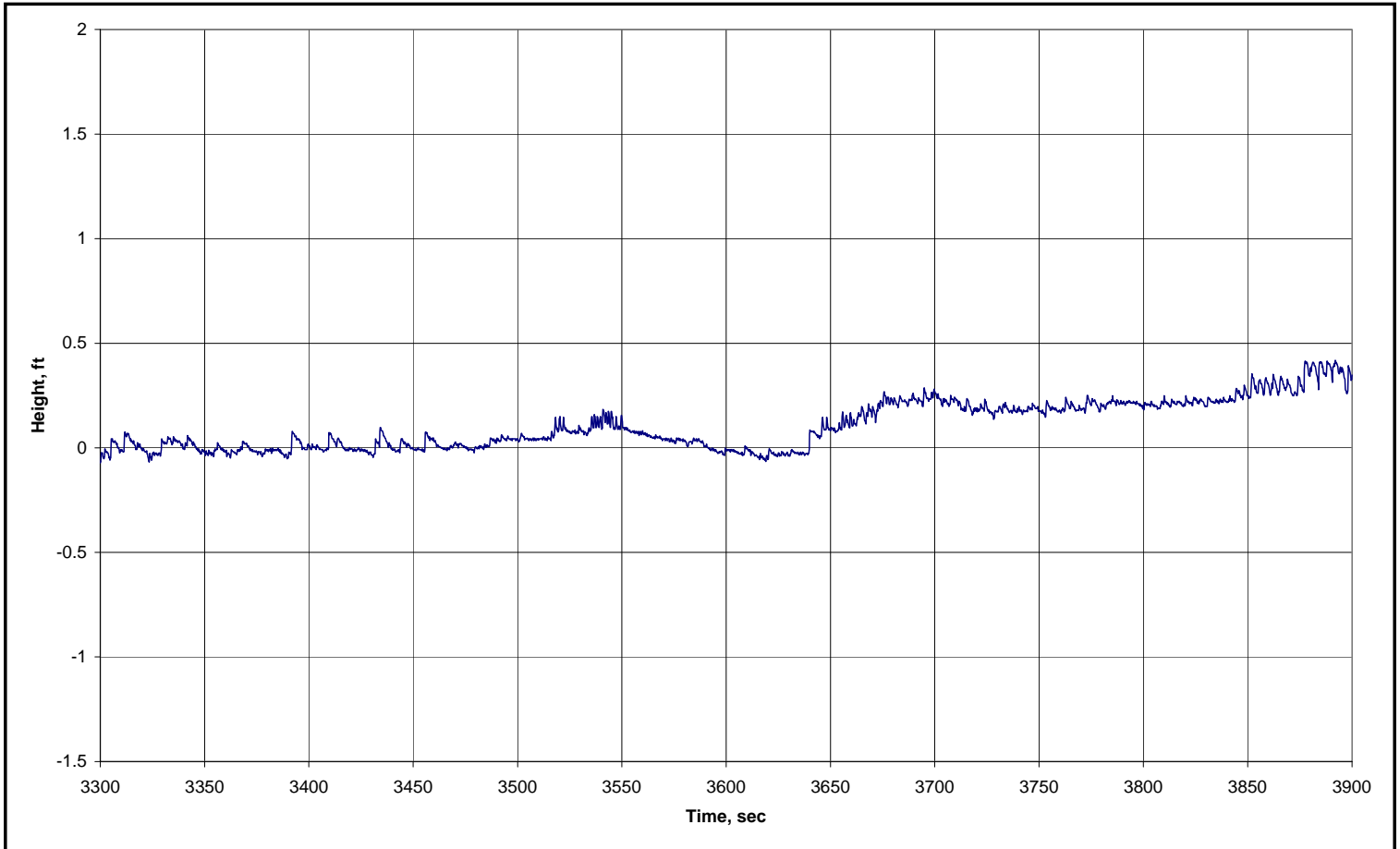

Figure D38. Kochnev, outbound, time 0 = 1500 EDT, 17 Sep 2005.

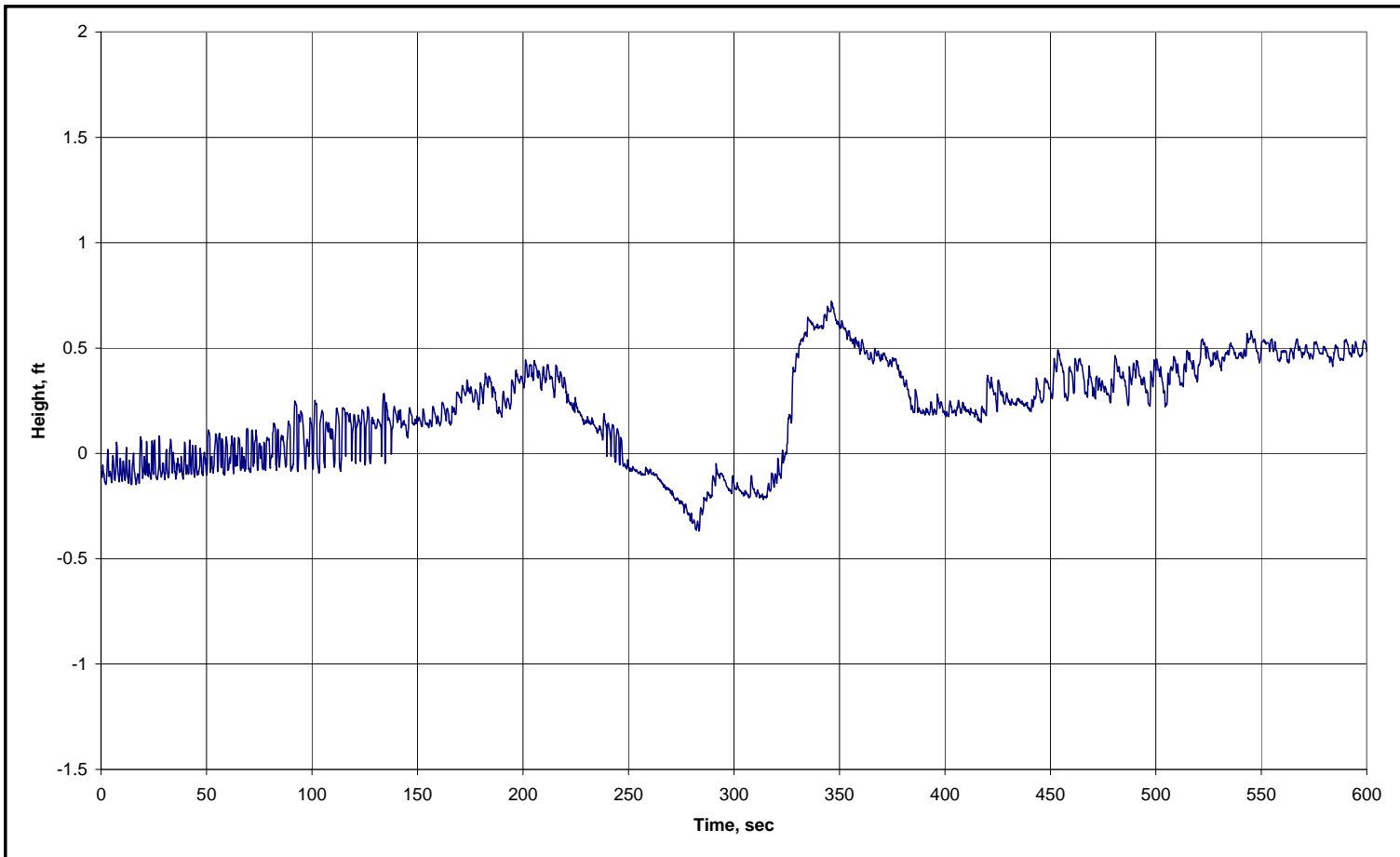

Figure D39. Jiang An Cheng, outbound, time 0 = 1700 EDT, 17 Sep 2005. 


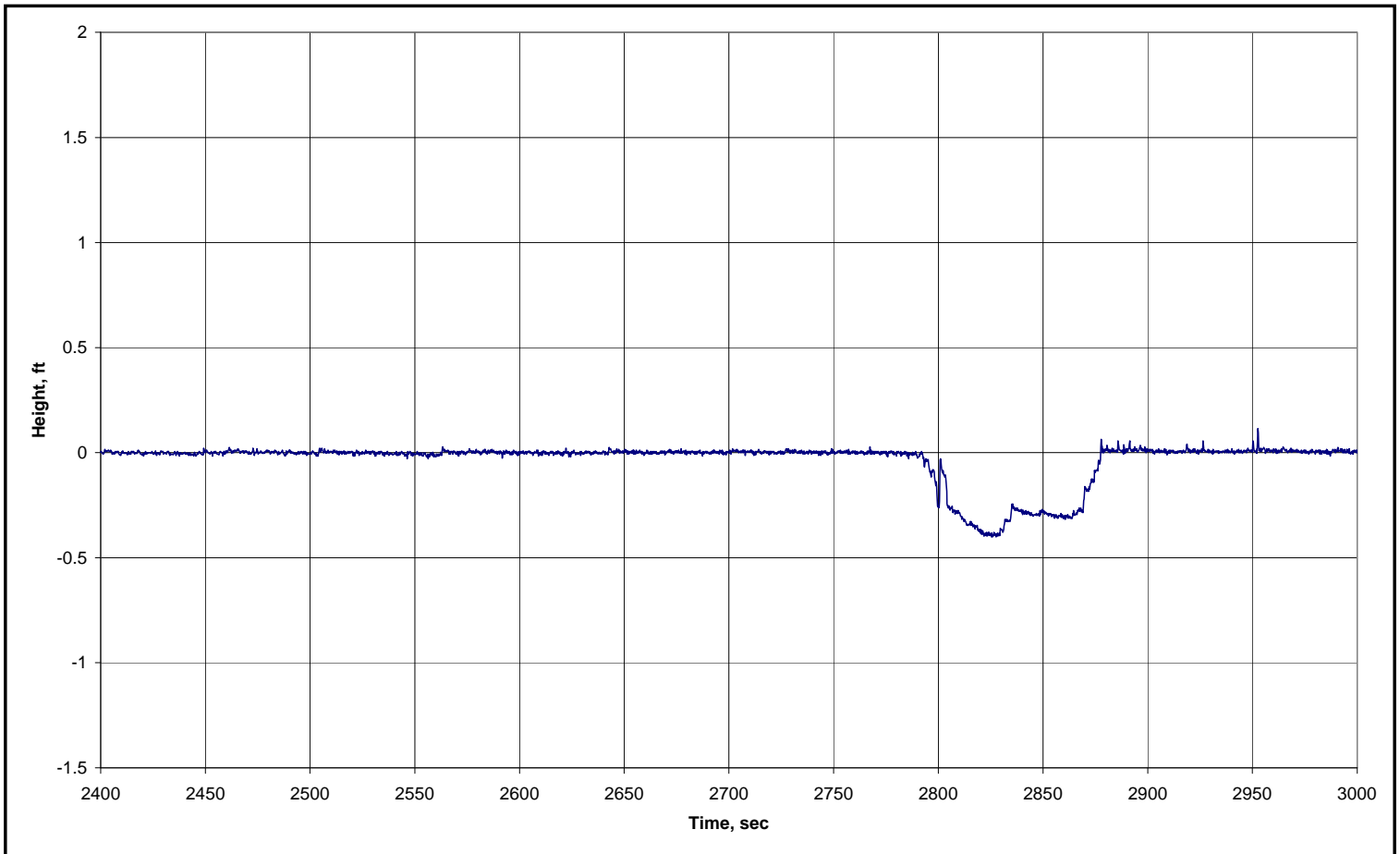

Figure D40. Mol Elbe, outbound, time 0 = 2000 EDT, 17 Sep 2005.

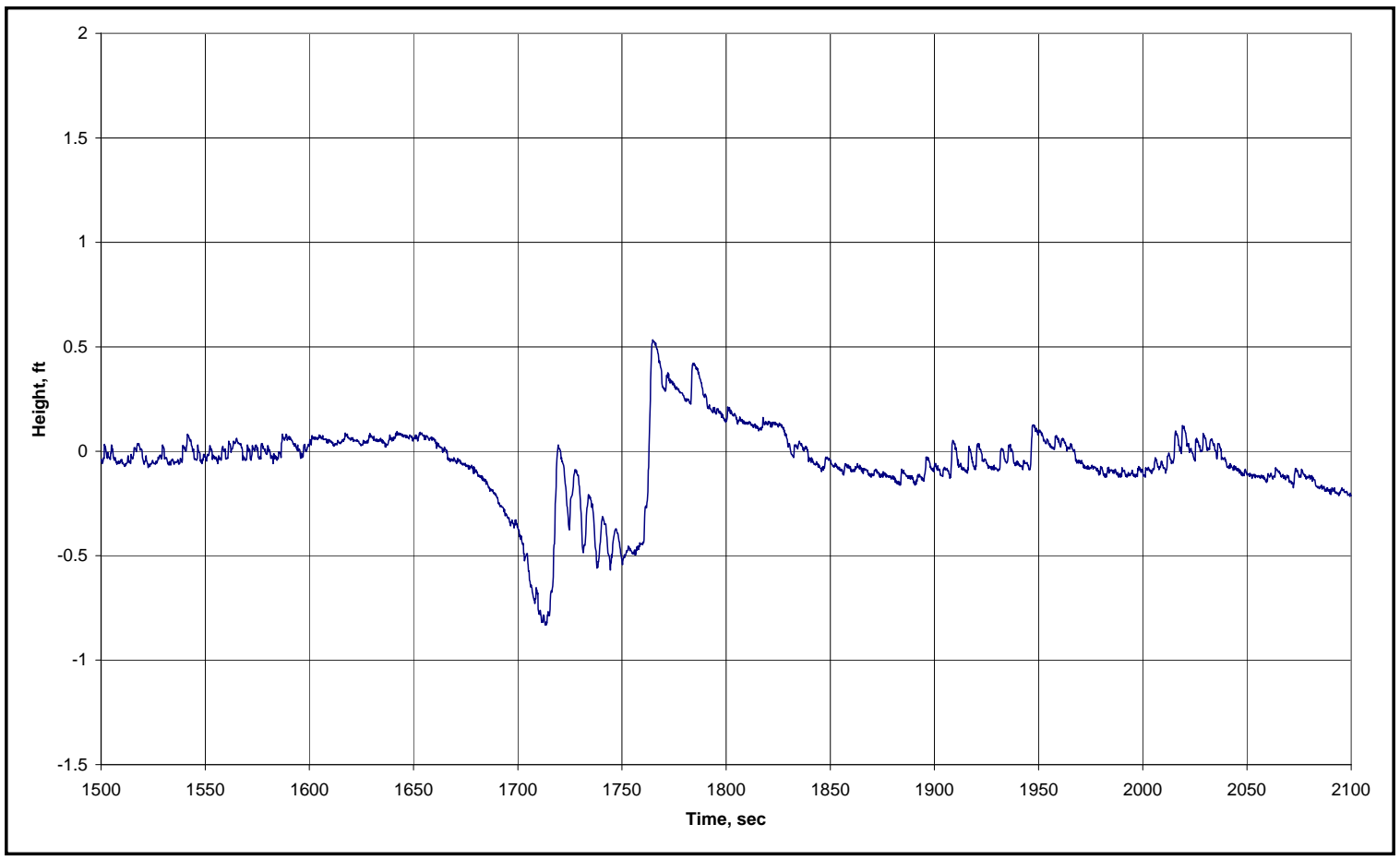

Figure D41. MSC Christina, outbound, time 0 = 2100 EDT, 17 Sep 2005. 


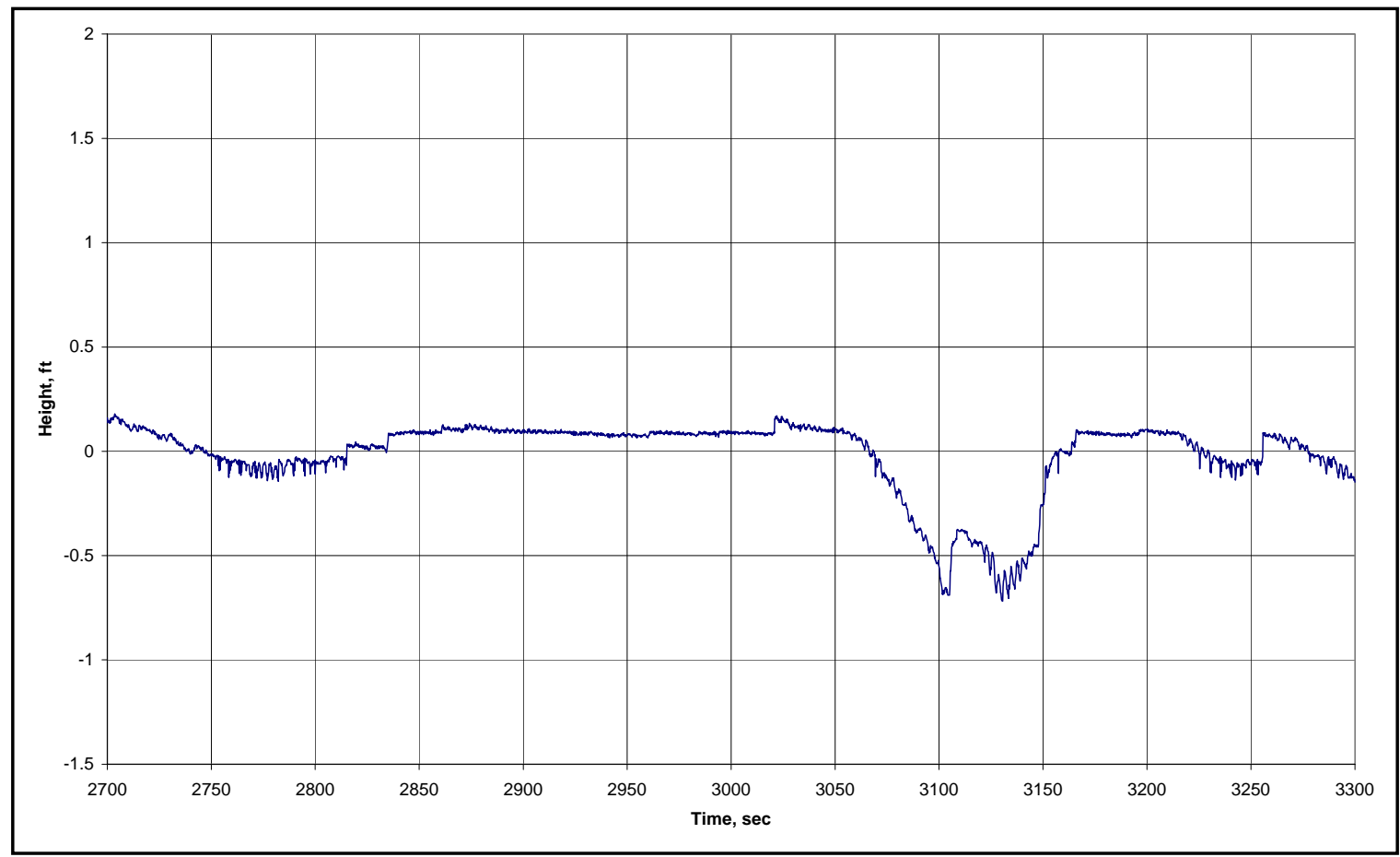

Figure D42. Zim Israel, outbound, time 0 = 2200 EDT, 17 Sep 2005.

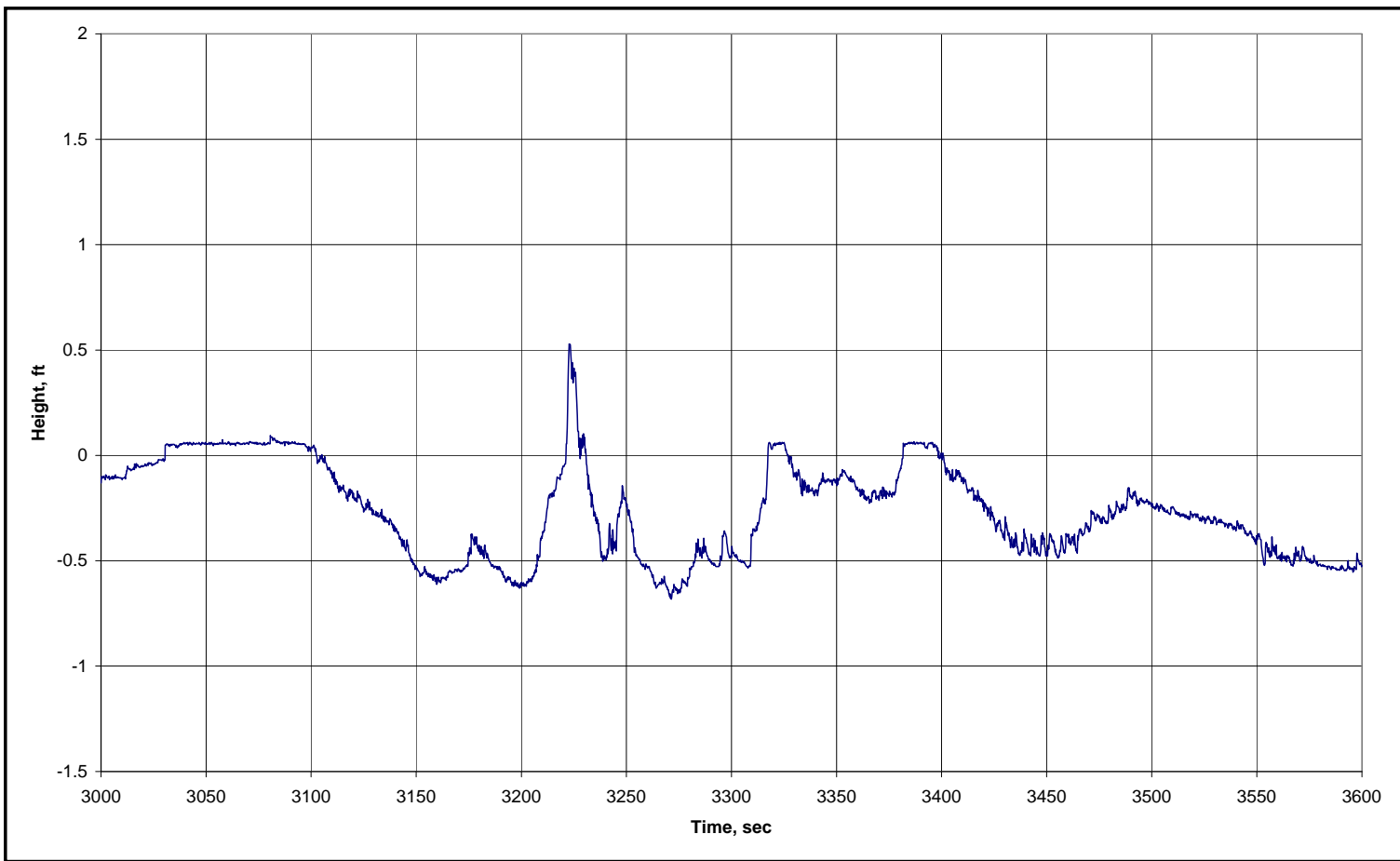

Figure D43. MSC Eleni, outbound, time 0 = 0100 EDT, 18 Sep 2005. 


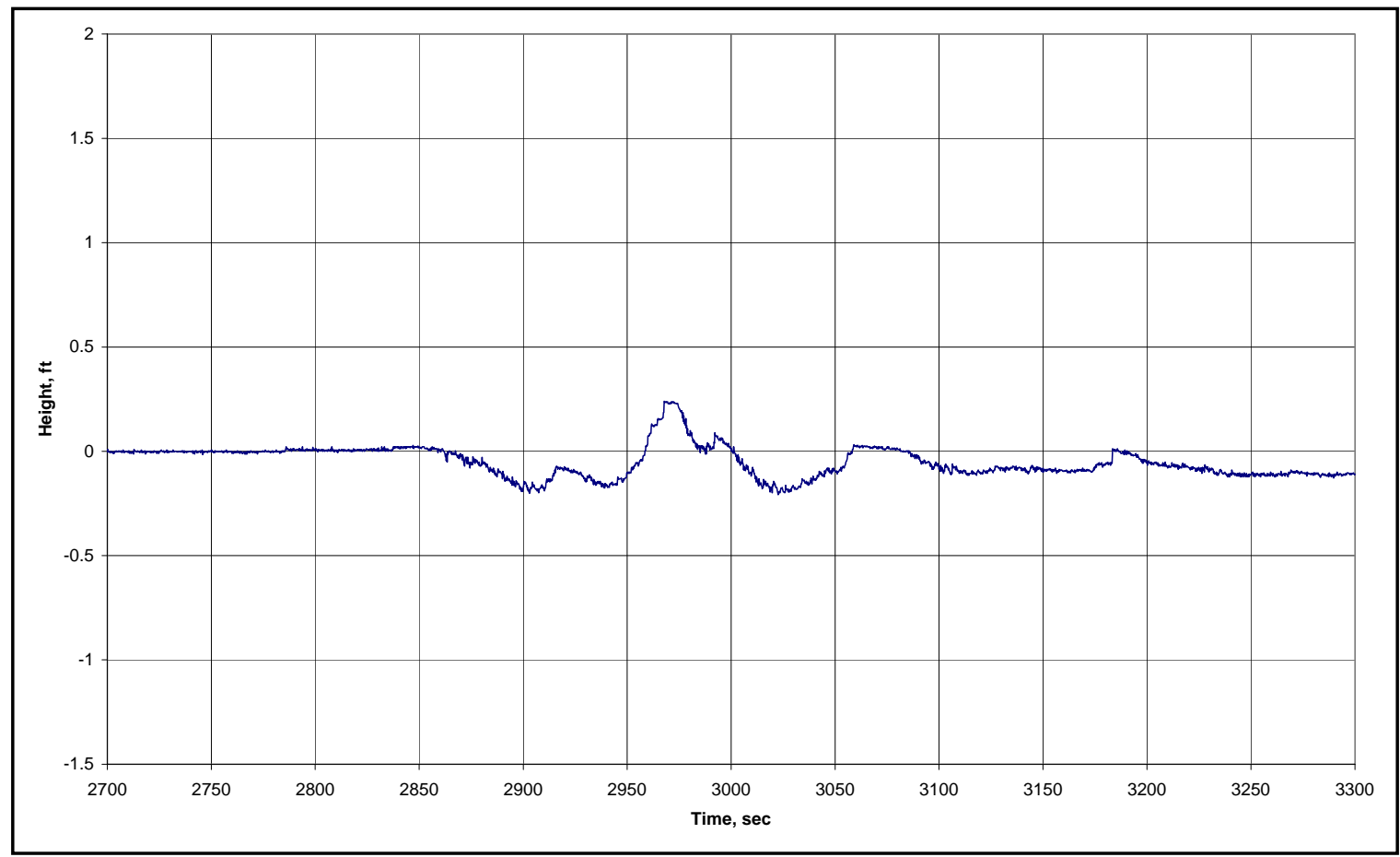

Figure D44. Midnight Sun, outbound, time 0 = 1400 EDT, 18 Sep 2005.

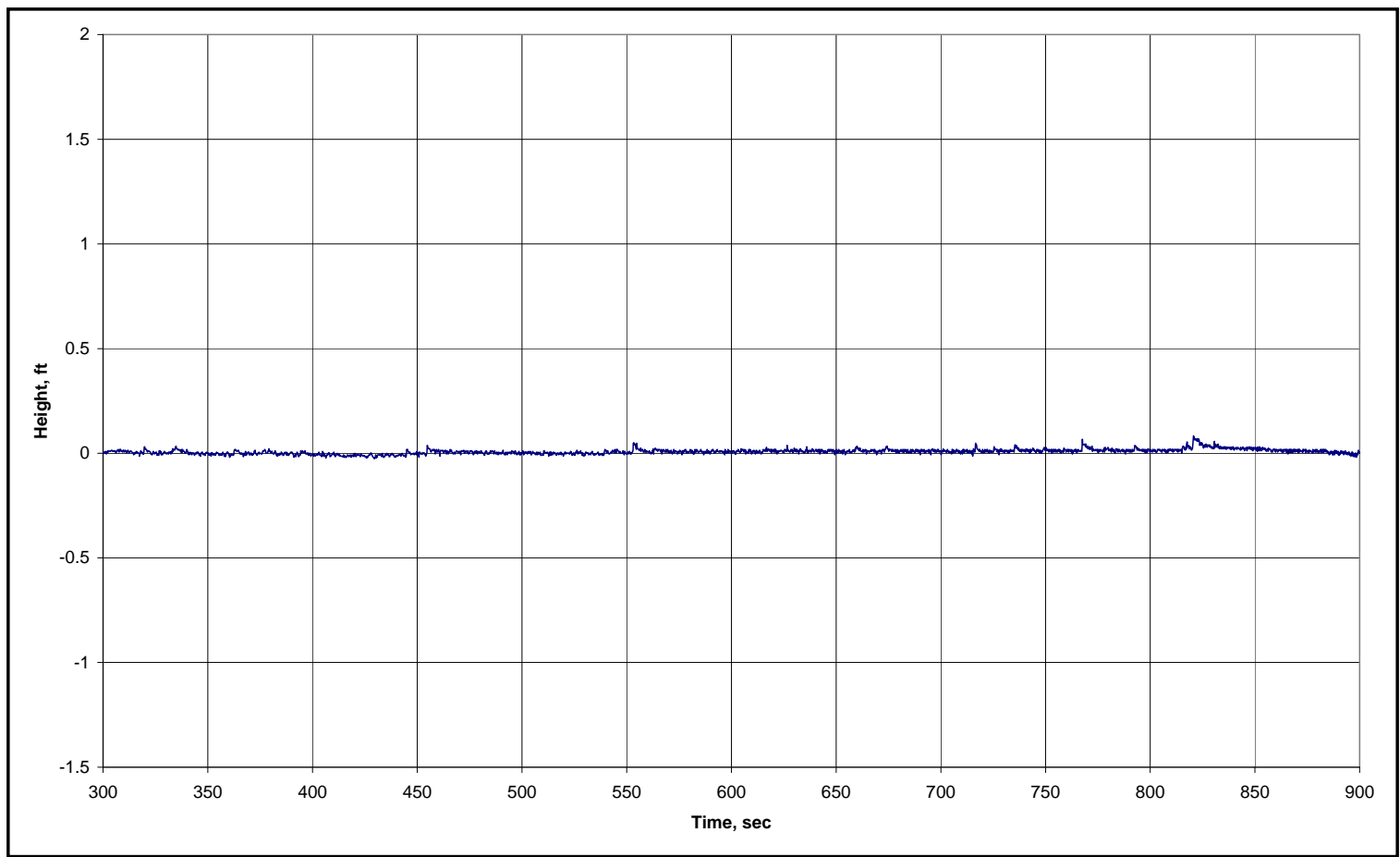

Figure D45. Alyona, outbound, time 0 = 2100 EDT, 18 Sep 2005. 


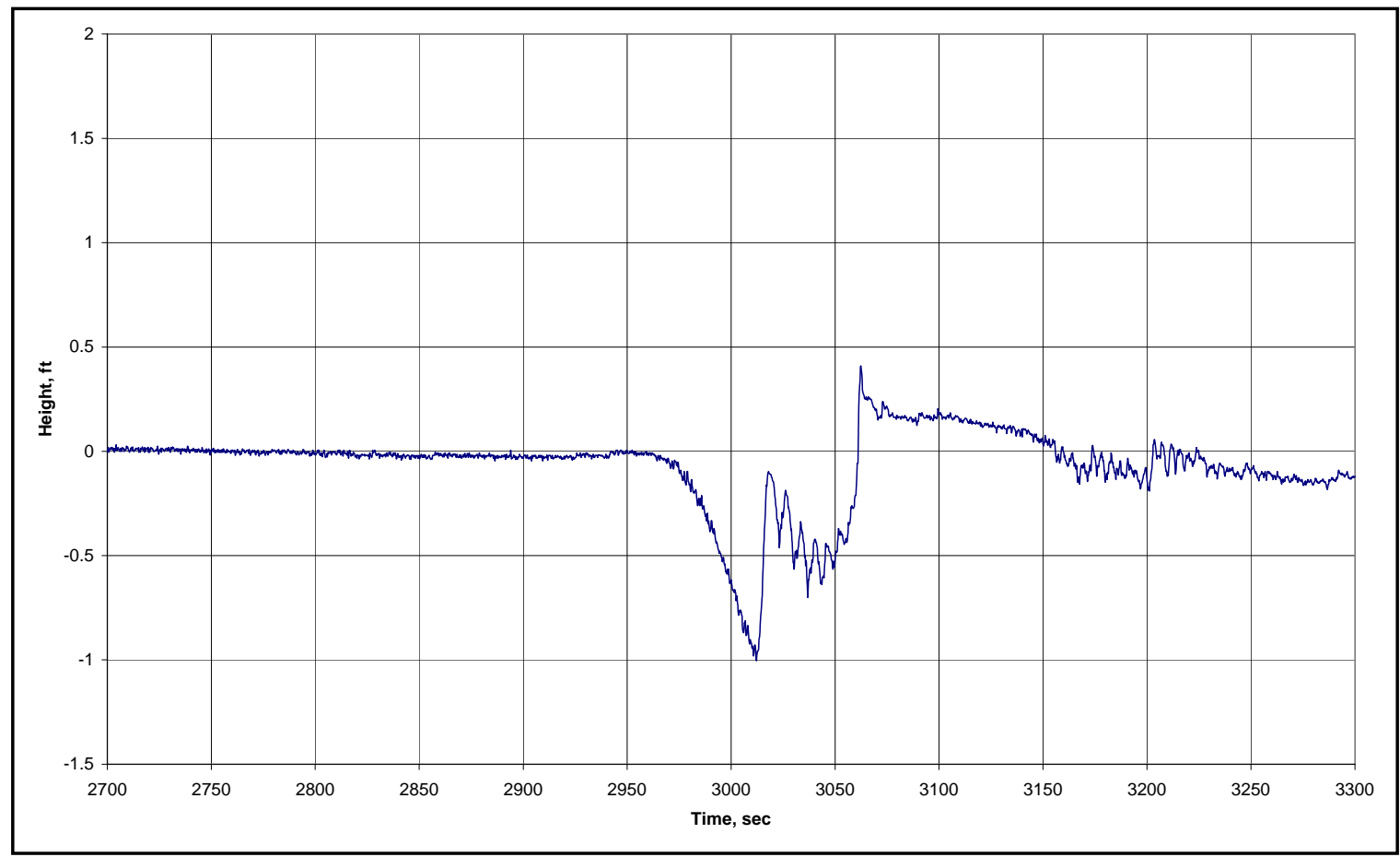

Figure D46. Alyona, outbound, time 0 = 2100 EDT, 18 Sep 2005.

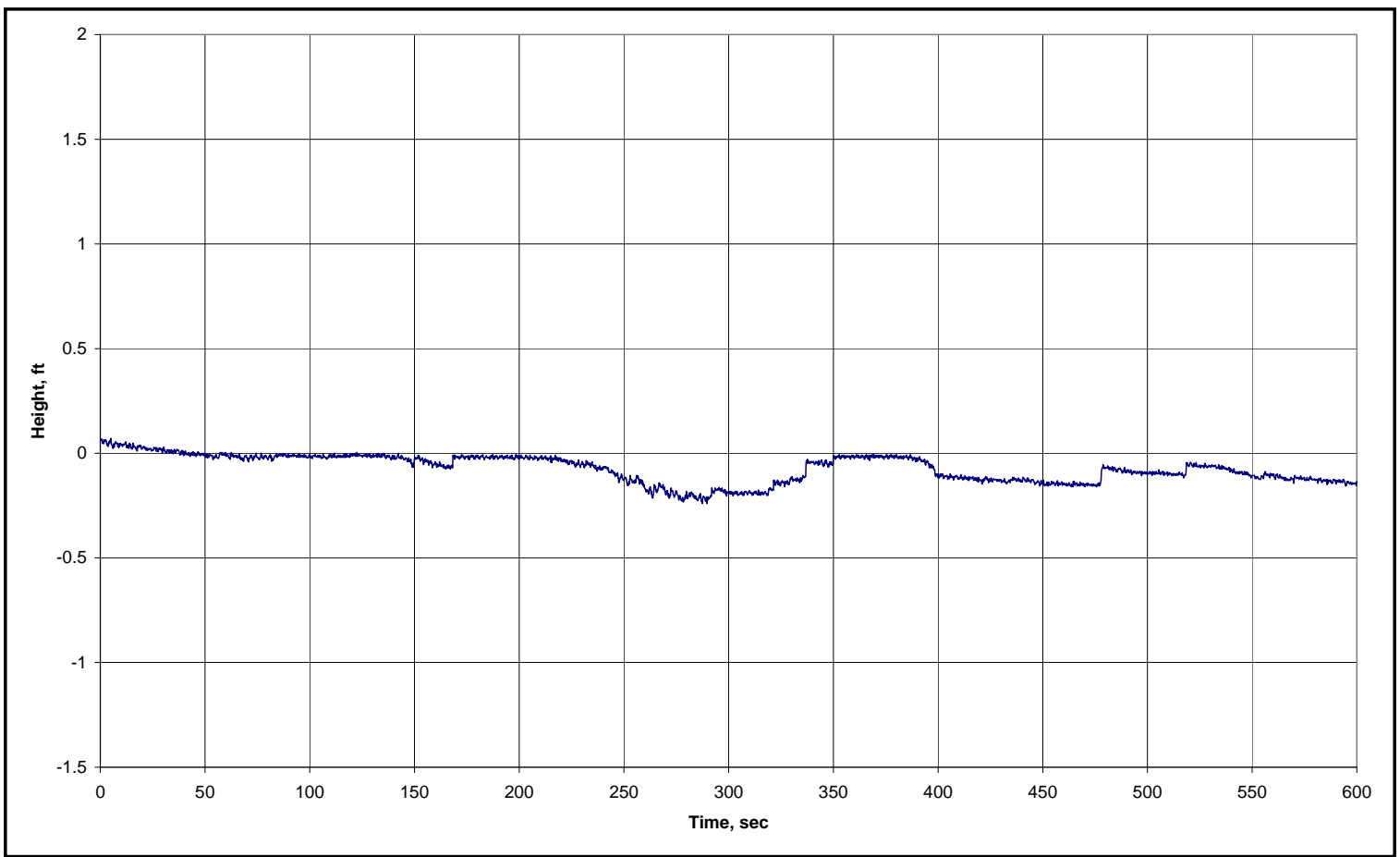

Figure D47. Darya Rani, outbound, time 0 = 2200 EDT, 18 Sep 2005. 


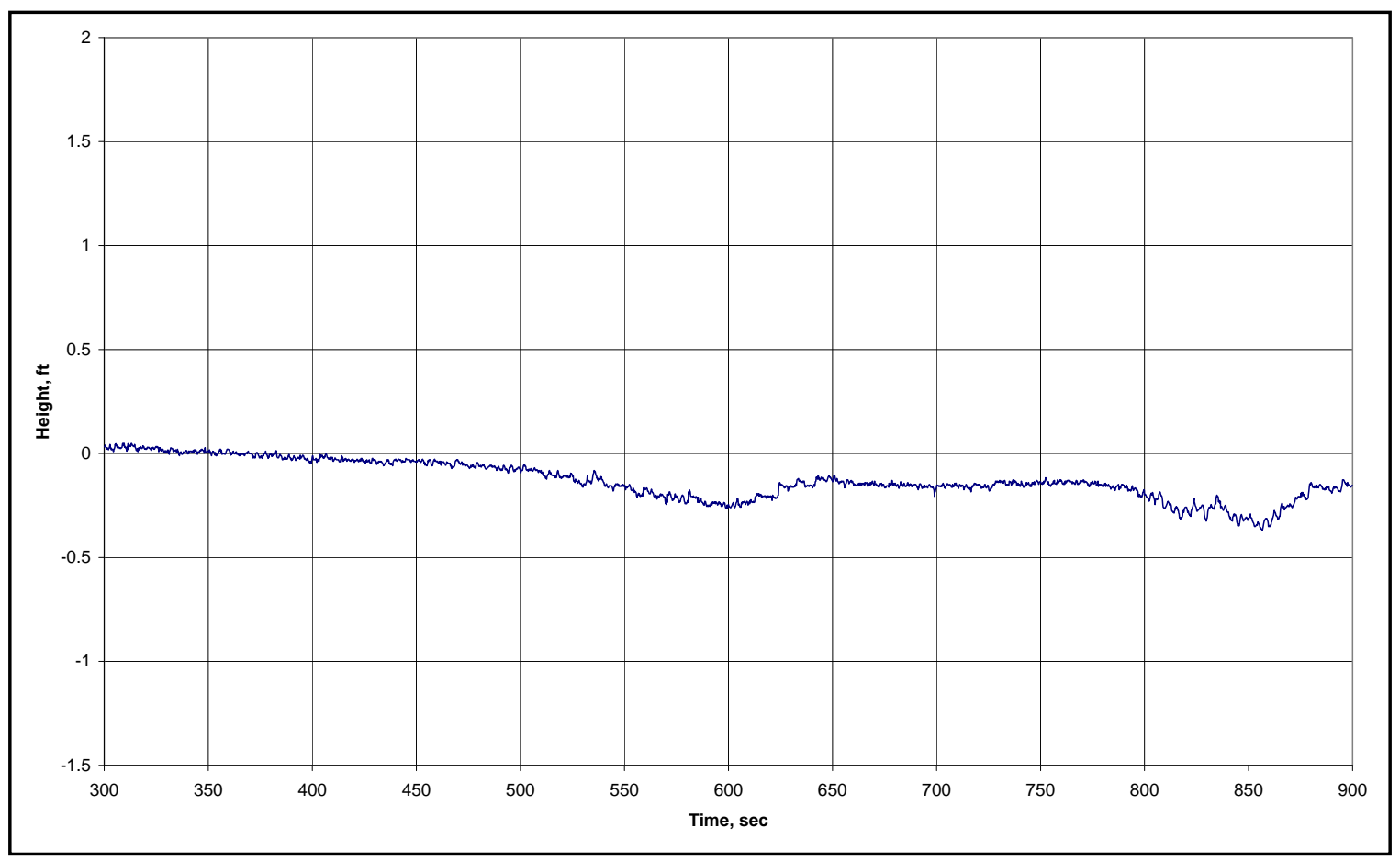

Figure D48. Sumida, outbound, time 0 = 2300 EDT, 18 Sep 2005.

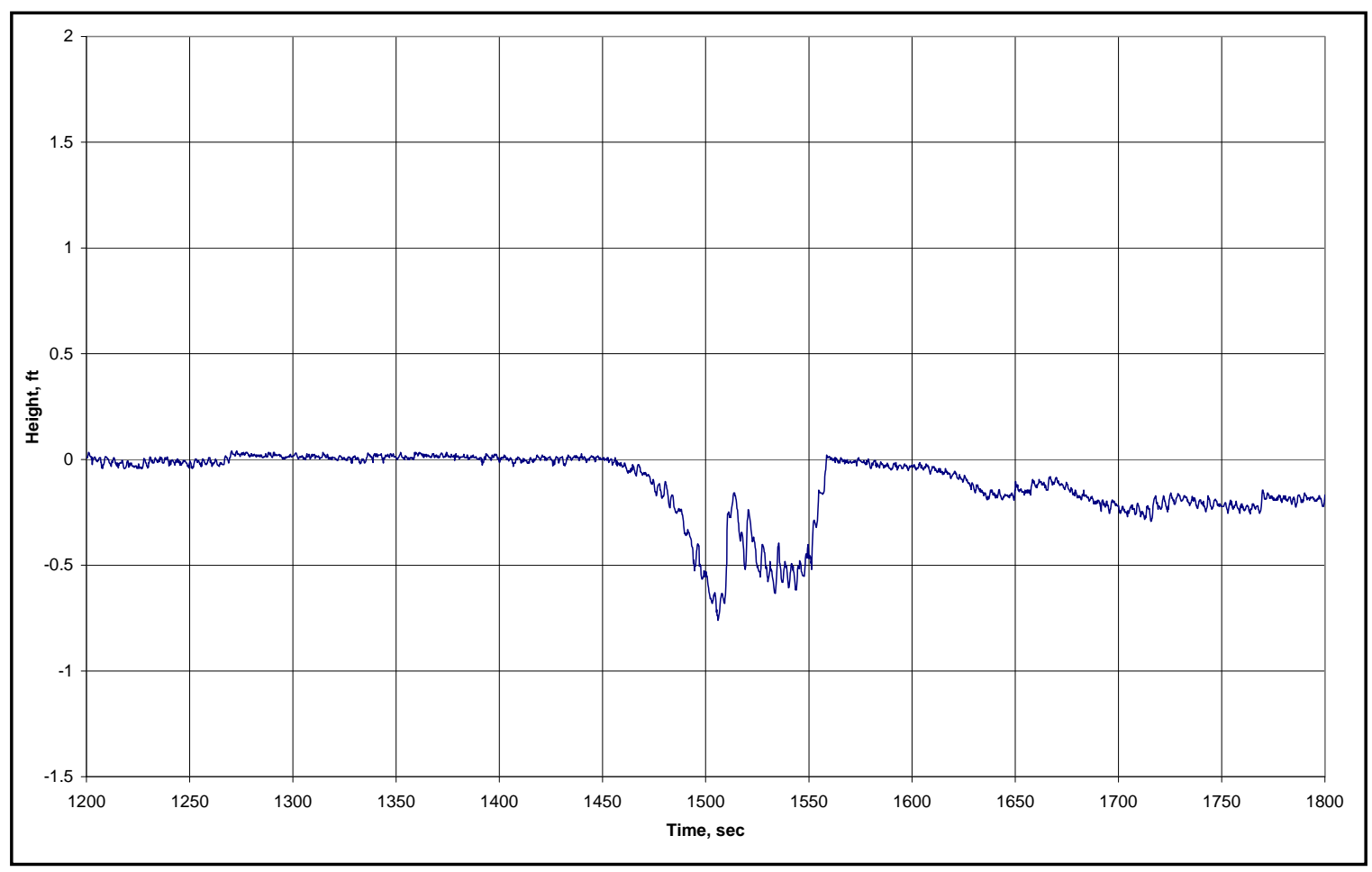

Figure D49. Al Mariyah, outbound, time 0 = 2300 EDT, 18 Sep 2005. 


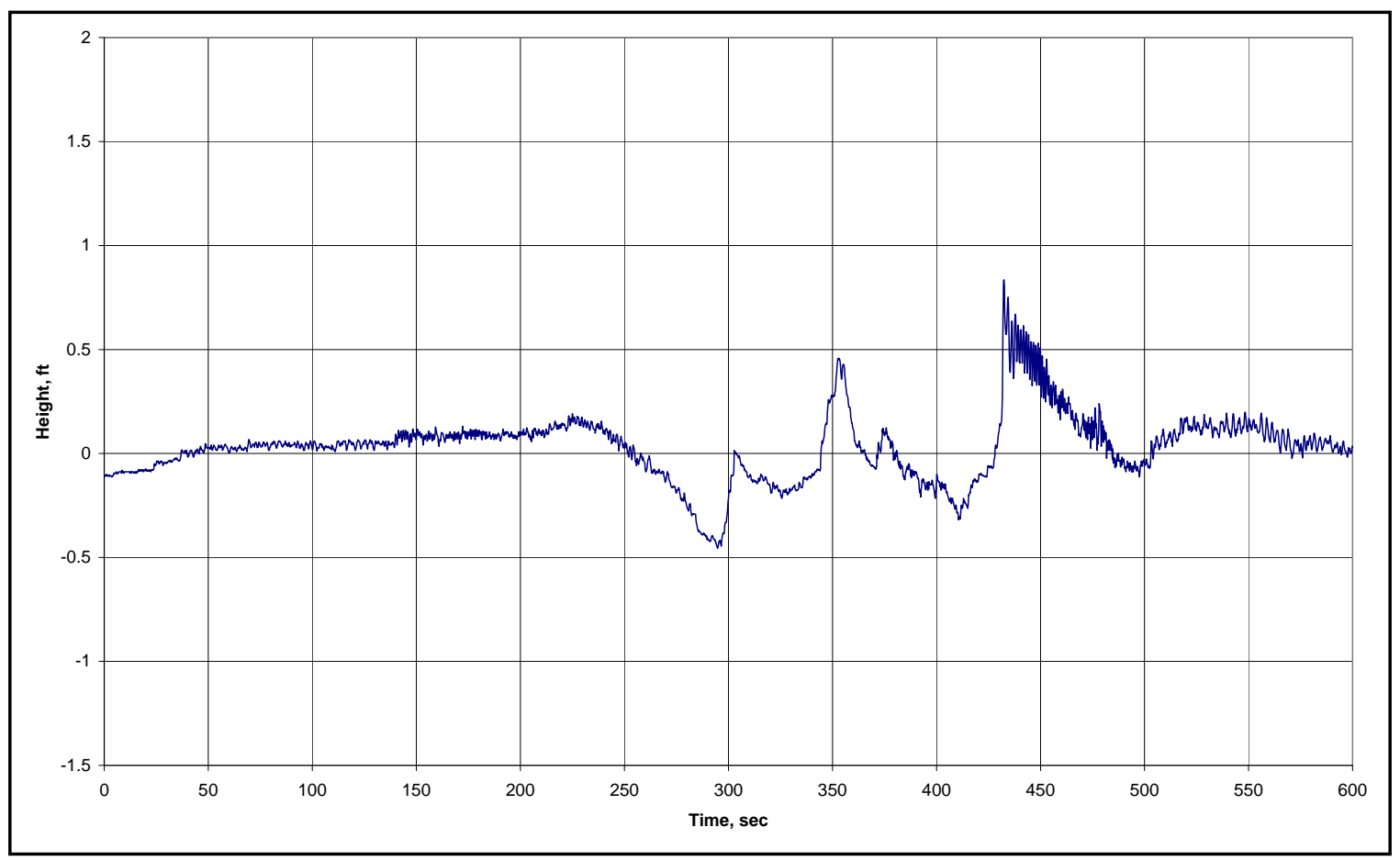

Figure D50. MSC Eleni, outbound, time 0 = 0400 EDT, 19 Sep 2005.

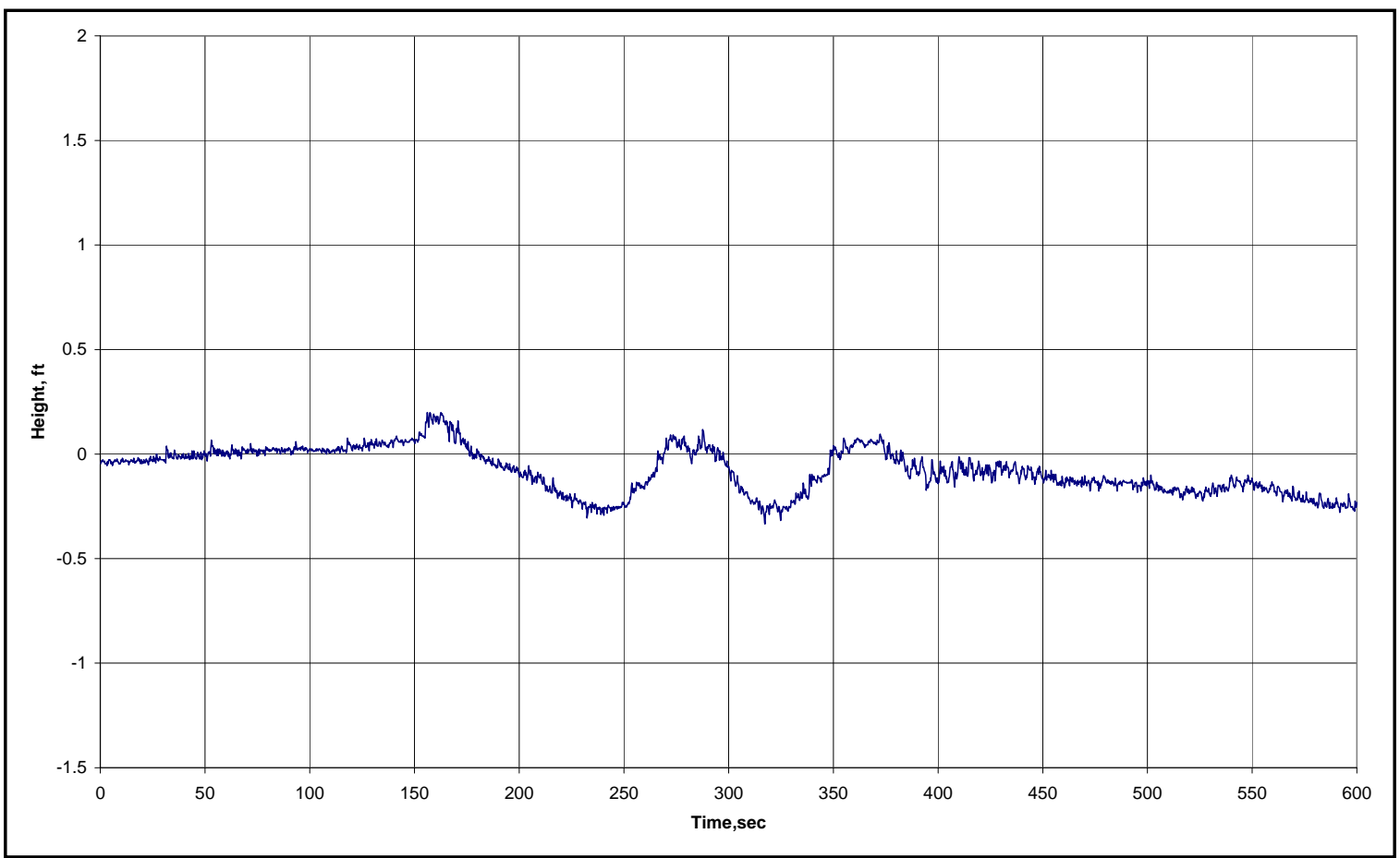

Figure D51. Condor, outbound, time 0 = 1500 EDT, 19 Sep 2005. 


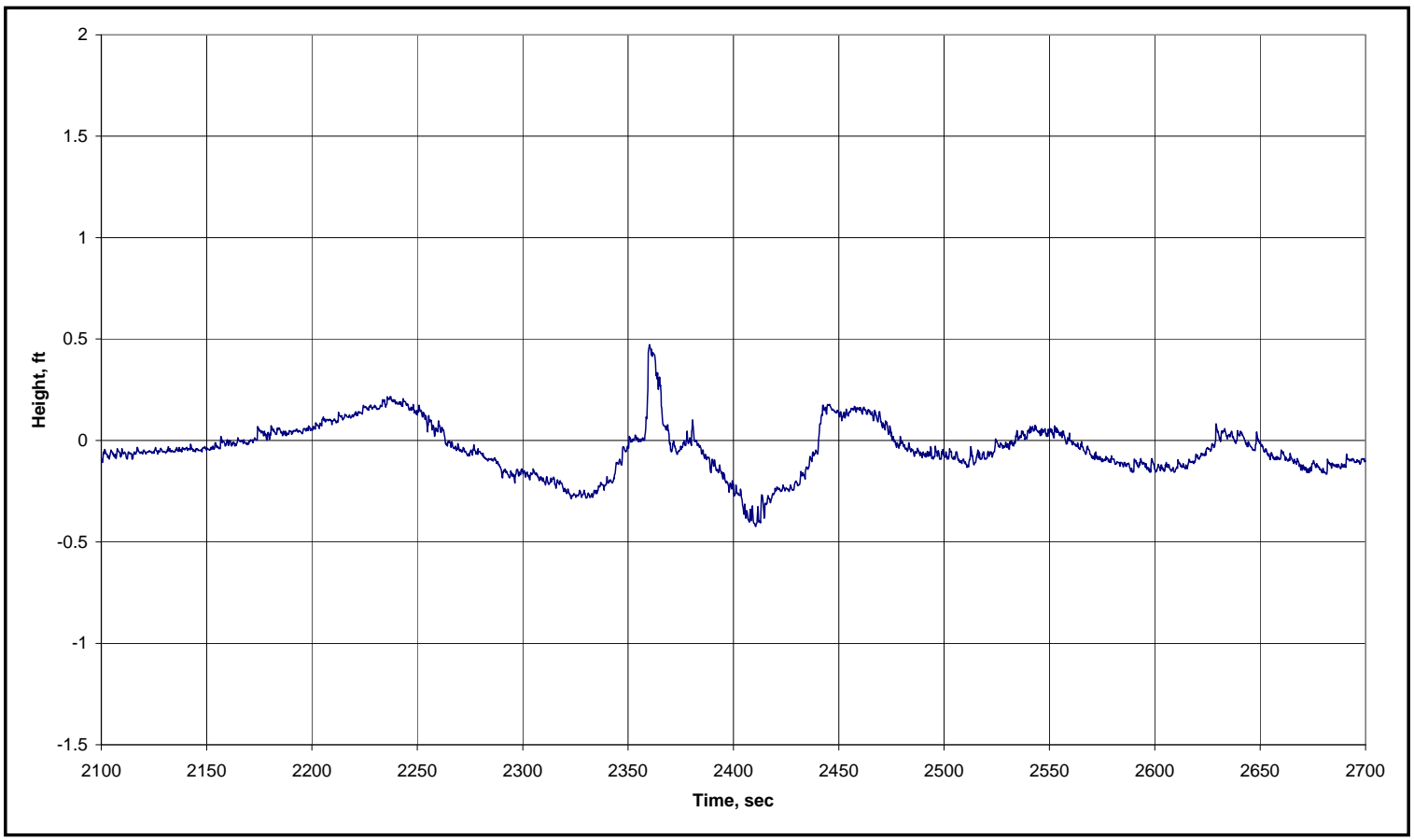

Figure D52. Emmanuelle Tomassos, outbound, time 0 = 1500 EDT, 19 Sep 2005.

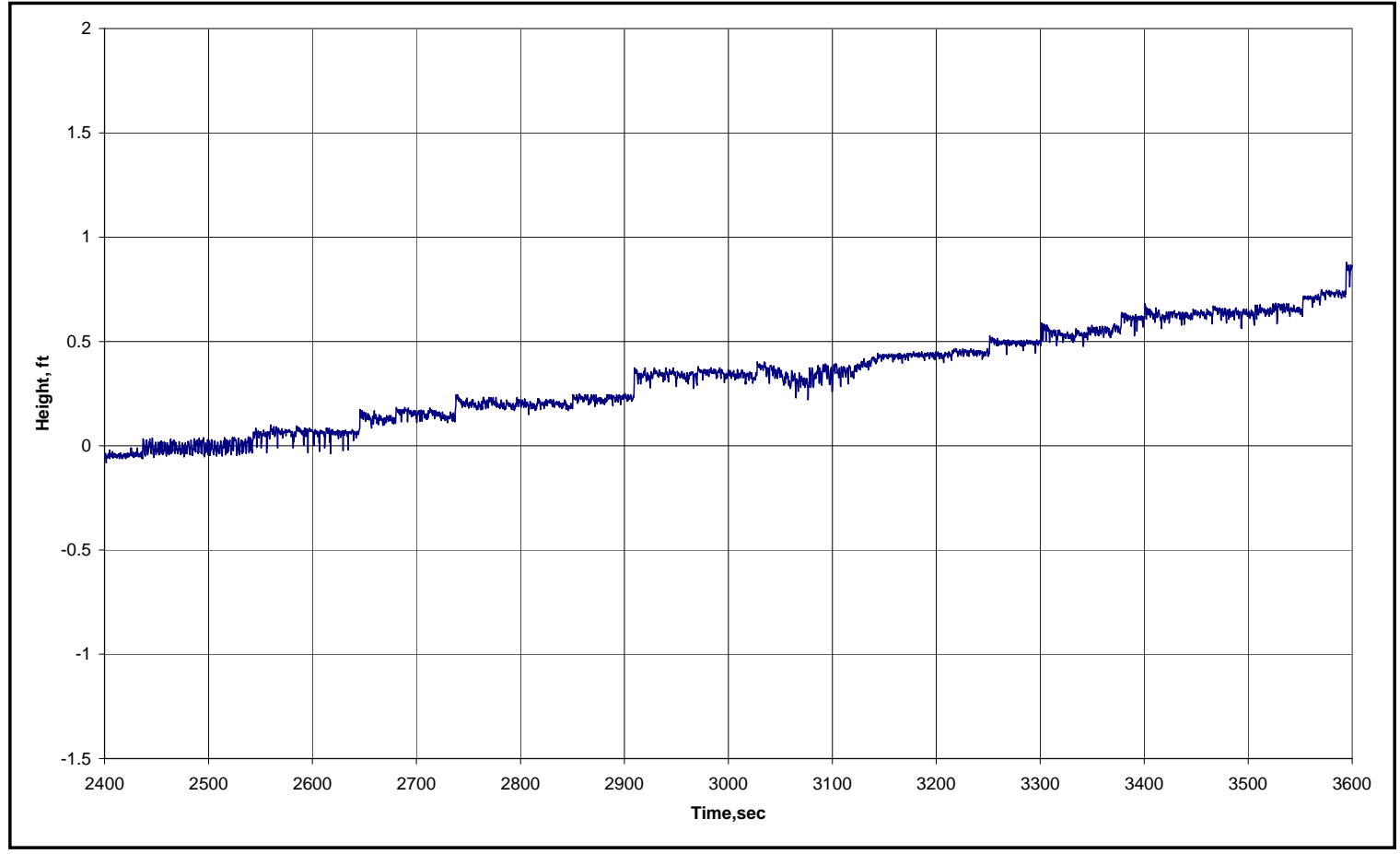

Figure D53. Nelson, outbound, time $0=1900$ EDT, 19 Sep 2005. 


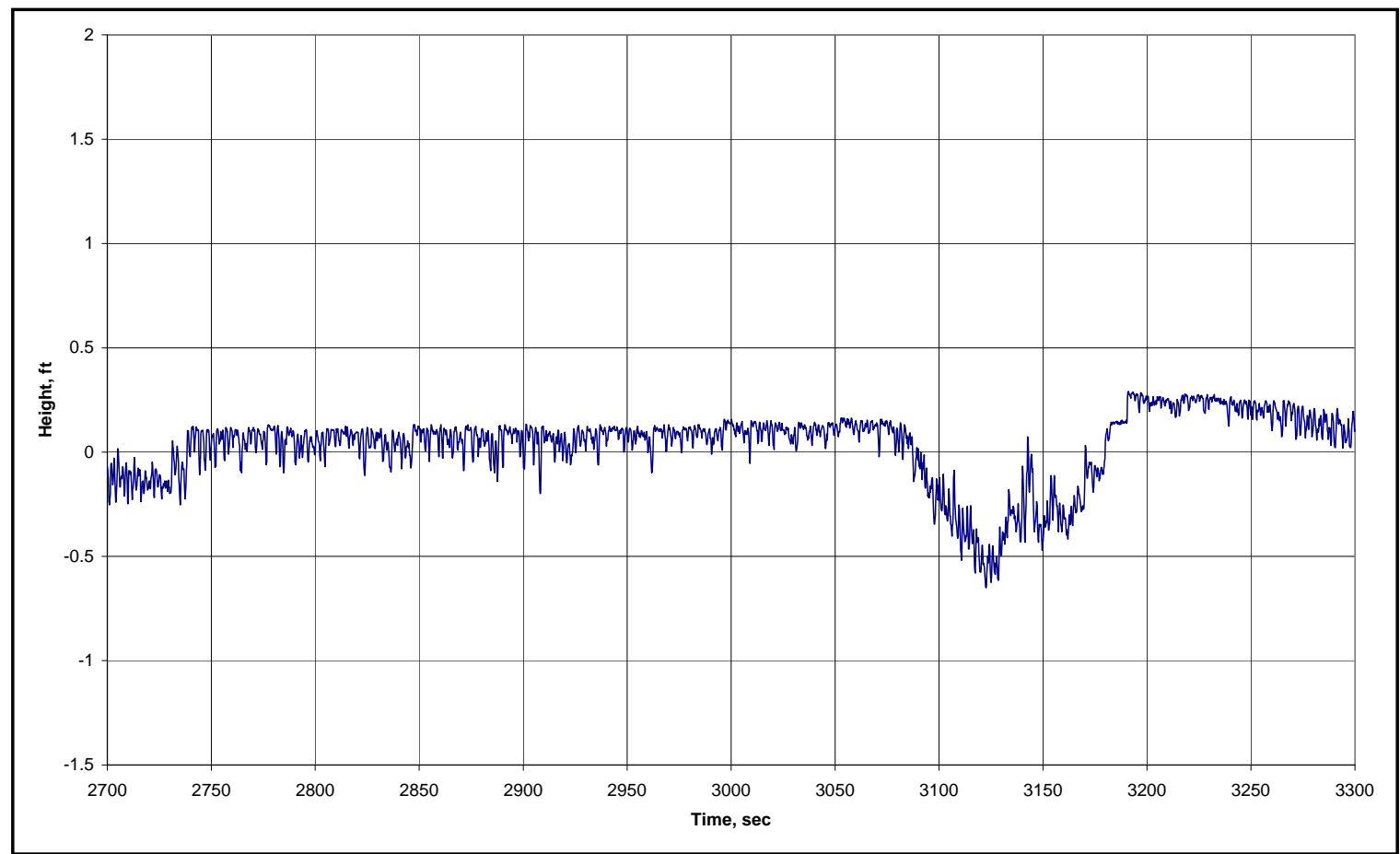

Figure D54. Victoria Bridge, outbound, time 0 = 2000 EDT, 19 Sep 2005.

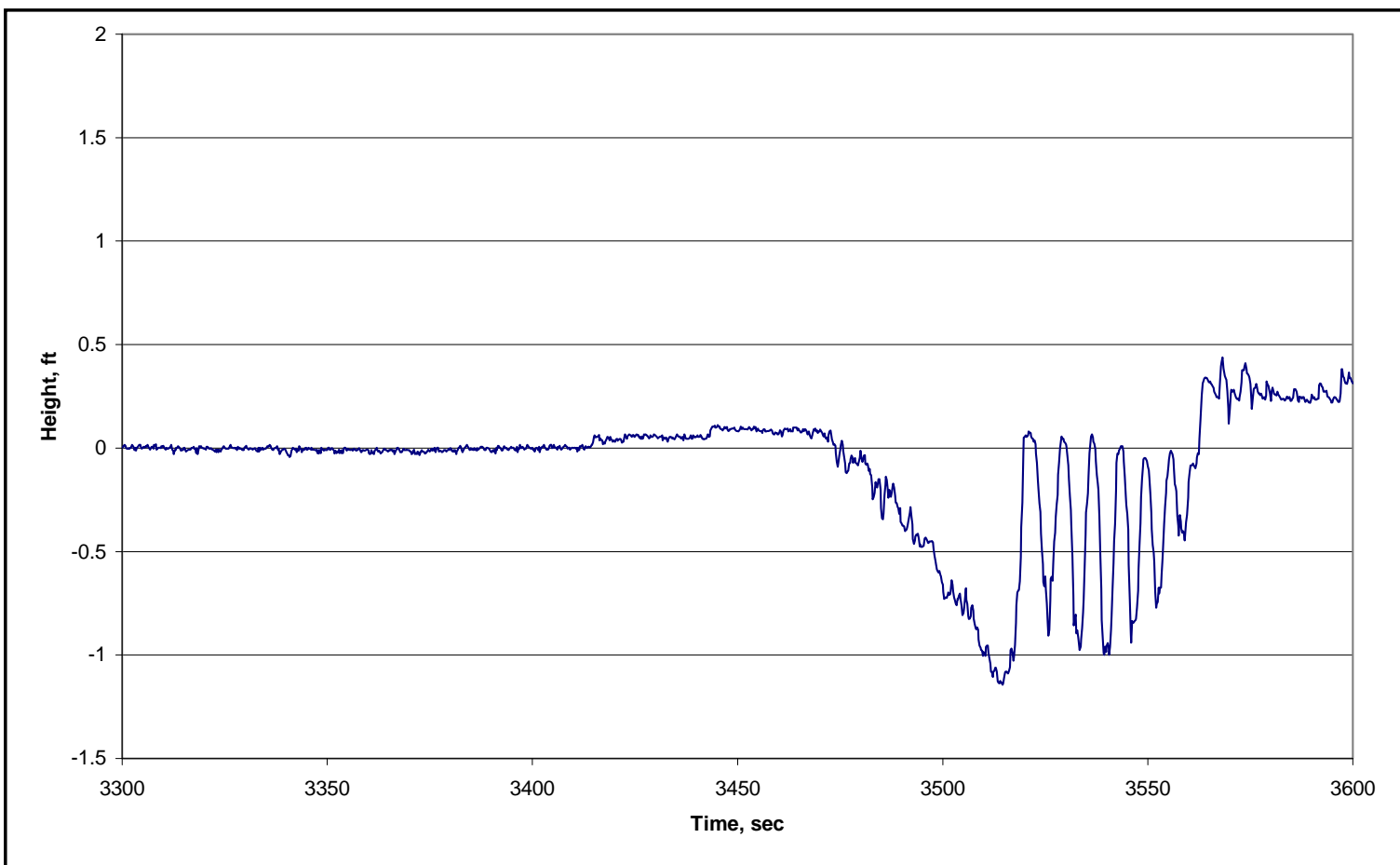

Figure D55. Hanjin Wilmington, outbound, time 0 = 2100 EDT, 19 Sep 2005. 


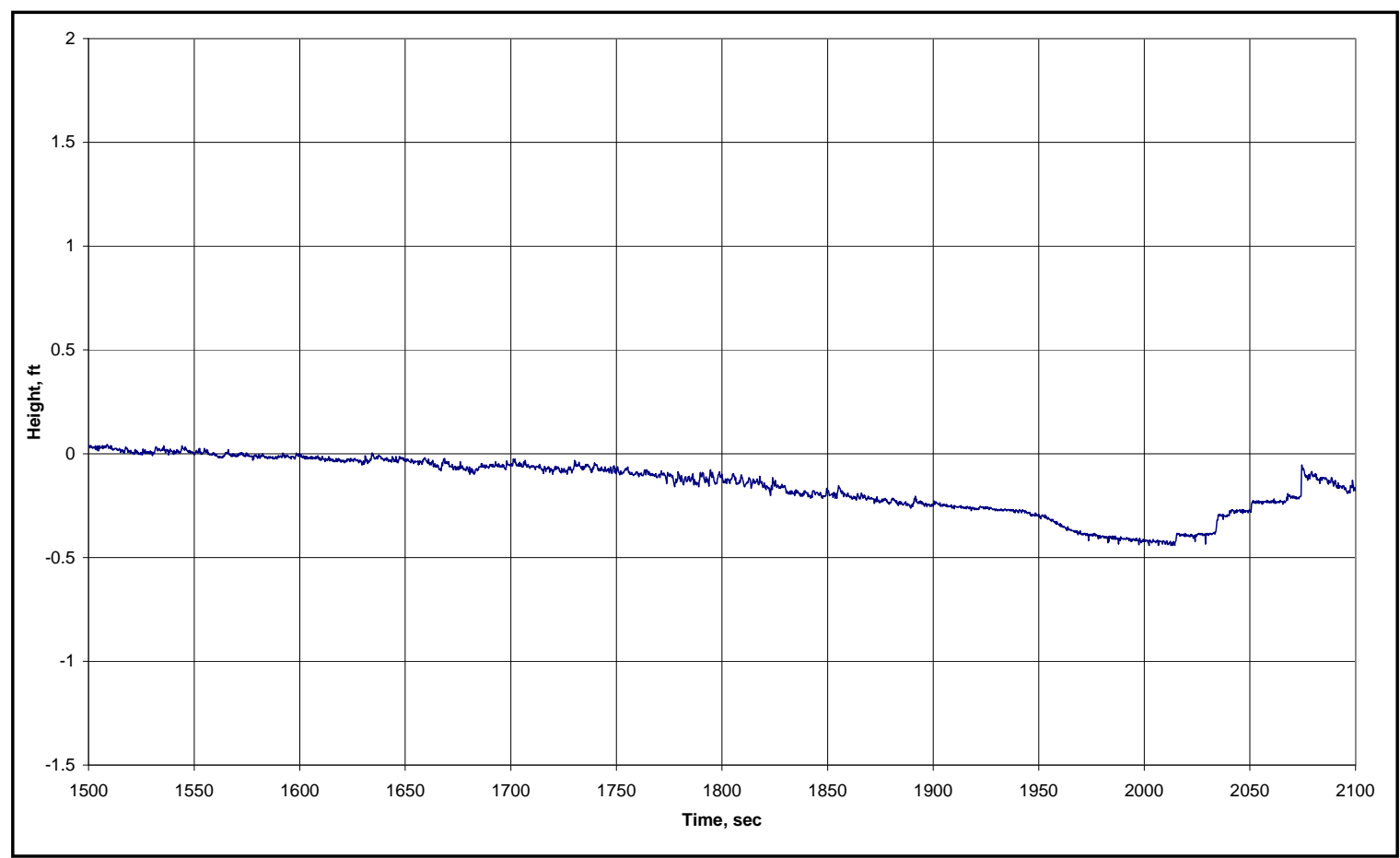

Figure D56. Julia, outbound, time 0 = 0200 EDT, 20 Sep 2005.

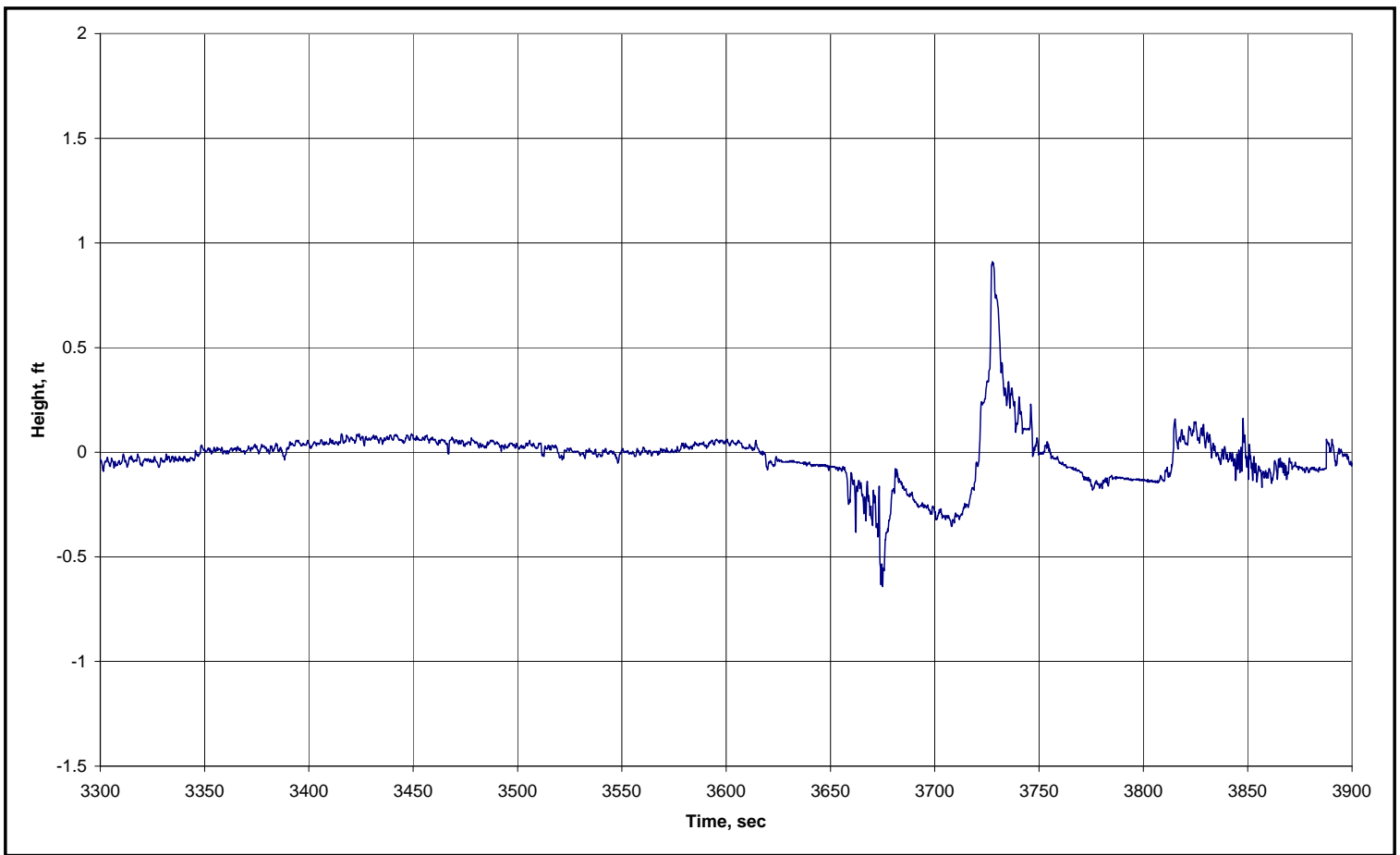

Figure D57. Essen Express, outbound, time 0 = 0300 EDT, 20 Sep 2005. 


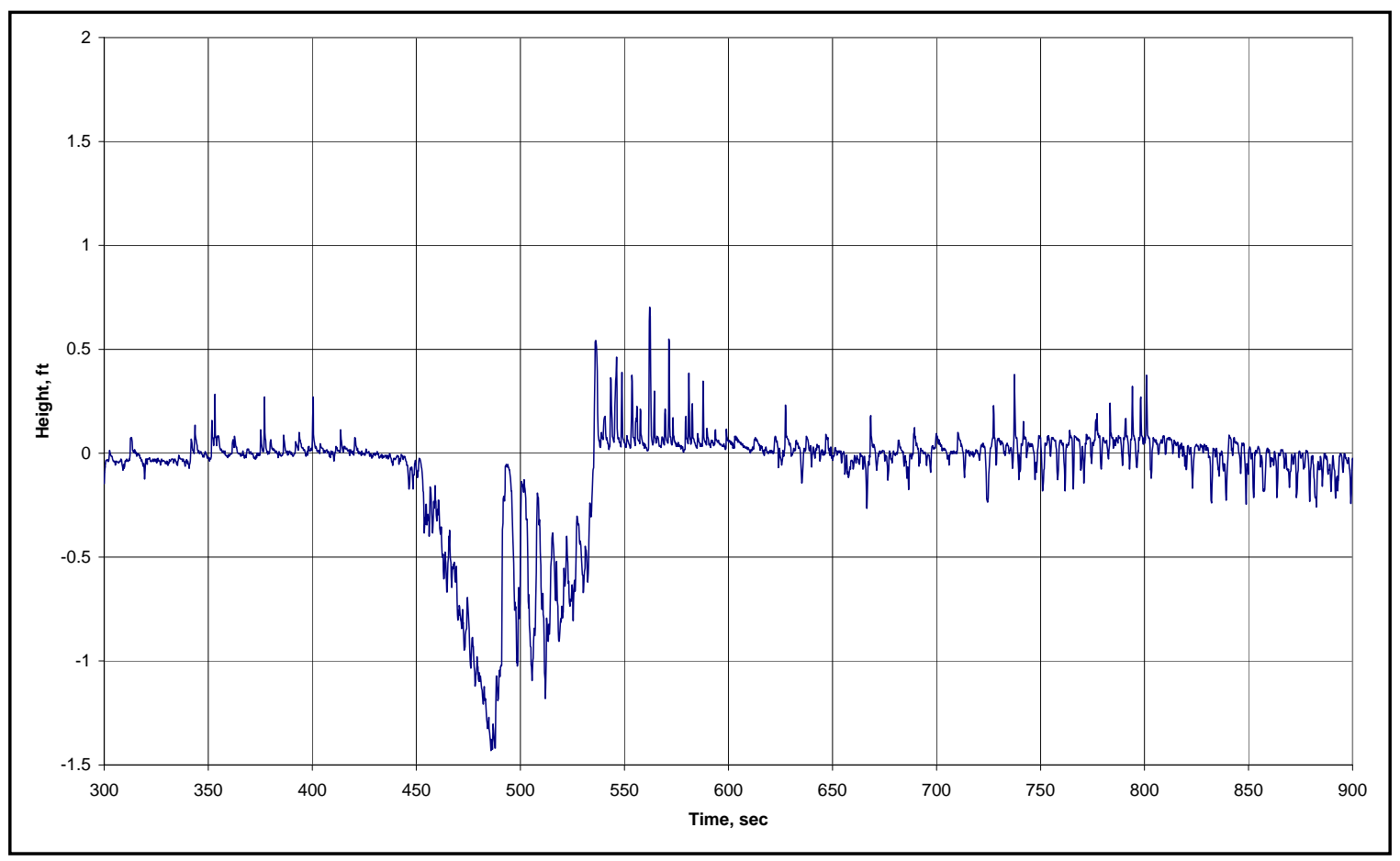

Figure D58. Mol Velocity, outbound, time 0 = 1000 EDT, 20 Sep 2005.

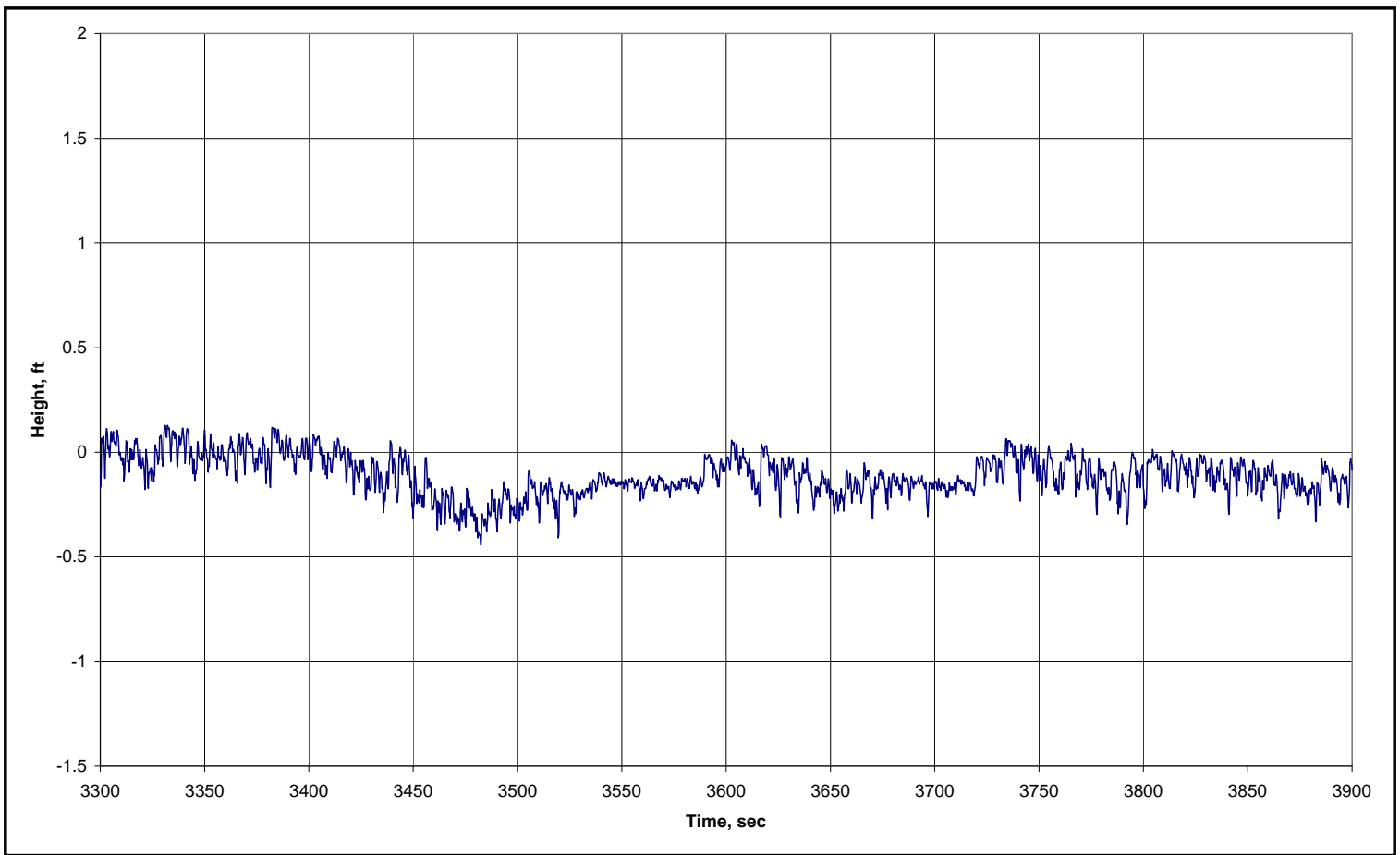

Figure D59. Kavo Alexandros II, outbound, time 0 = 1000 EDT, 20 Sep 2005. 


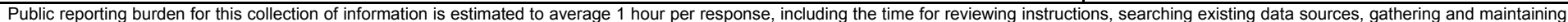

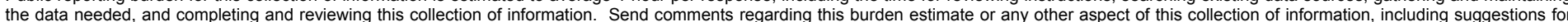

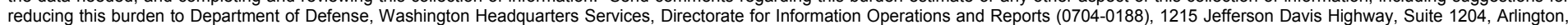

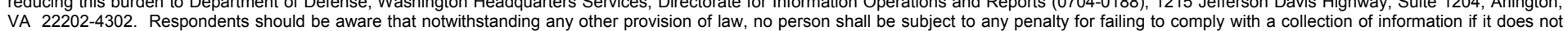
VA 22202-4302. Respondents should be aware that notwithstanding any other provision of law, no person shall be sube
display a currently valid OMB control number. PLEASE DO NOT RETURN YOUR FORM TO THE ABOVE ADDRESS.
1. REPORT DATE (DD-MM-YYYY)
August 2007

4. TITLE AND SUBTITLE

Ship Forces on the Shoreline of the Savannah Harbor Project

3. DATES COVERED (From - To)

5a. CONTRACT NUMBER

5b. GRANT NUMBER

5c. PROGRAM ELEMENT NUMBER

5d. PROJECT NUMBER

5e. TASK NUMBER

5f. WORK UNIT NUMBER

8. PERFORMING ORGANIZATION REPORT NUMBER

ERDC/CHL TR-07-7

U.S. Army Engineer Research and Development Center

3909 Halls Ferry Road

Vicksburg, MS 39180-6199

9. SPONSORING / MONITORING AGENCY NAME(S) AND ADDRESS(ES)

U.S. Army Corps of Engineers

Washington, DC 20314-1000

12. DISTRIBUTION / AVAILABILITY STATEMENT

Approved for public release; distribution is unlimited.

\section{SUPPLEMENTARY NOTES}

\section{ABSTRACT}

Ship forces having the potential to cause shoreline erosion were evaluated at Savannah Harbor to compare the without-project (existing) and the with-project (deepened) channels. Comparable ship speeds were determined in the without-project and with-project channels based on field data and an analytical model. Four traffic alternatives were evaluated that primarily differ in the number of post-Panamax ships compared to Panamax ships. At Fort Pulaski, dominant ship effects include short period bow and stern waves and long period drawdown and return velocity. The composite return velocity and drawdown per ship are 3.2 to 6.2 percent less in the with-project channel. Due to the slightly higher speed in the with-project channel, short period bow and stern waves are the shoreline attack force that increases in the with-project channel at Fort Pulaski. The composite short period bow and stern wave height per ship for years 2030 and 2050 is predicted to be 1.5 to 4.4 percent greater in the deepened channel. At Tybee Island, the only significant ship effect reaching the shoreline is the long period drawdown or pressure wave. The composite drawdown in the channel between the jetties per ship is 2.3 to 5.9 percent less in the with-project channel.

\section{SUBJECT TERMS}

16. SECURITY CLASSIFICATION OF:

a. REPORT

UNCLASSIFIED

b. ABSTRACT
UNCLASSIFIED

UNCLASSIFIED

\begin{tabular}{l|c|}
$\begin{array}{l}\text { 17. LIMITATION } \\
\text { OF ABSTRACT }\end{array}$ & $\begin{array}{c}\text { 18. NUMBER } \\
\text { OF PAGES }\end{array}$ \\
& 150
\end{tabular}

19a. NAME OF RESPONSIBLE PERSON

19b. TELEPHONE NUMBER (include area code) 